\title{
The ammonoids from the Argiles de Teguentour of Oued Temertasset (early Late Tournaisian; Mouydir, Algeria)
}

\author{
Dieter Korn $^{*}, 1$, Jürgen Bockwinkel ${ }^{2}$ and Volker Ebbighausen ${ }^{3}$ \\ ${ }^{1}$ Museum für Naturkunde Berlin, Invalidenstraße 43, 10115 Berlin, Germany. E-mail: dieter.korn@mfn-berlin.de \\ 2 Dechant-Feinstraße 22, 51375 Leverkusen, Germany. E-mail: jbockwinkel@t-online.de \\ ${ }^{3}$ Engstenberger Höhe 12, 51519 Odenthal, Germany. E-mail: volker@vxr.de
}

Received 12 July 2009

Accepted 19 September 2009

Published 19 February 2010

\begin{abstract}
The ammonoids from the Teguentour Shales (Tournaisian, Early Carboniferous) of Oued Temertasset (Mouydir, Algeria) are described monographically. The following new ammonoid taxa are introduced: Imitoceras dimidium n. sp., Imitoceras strictum n. sp., Triimitoceras tantulum n. sp., Acrocanites disparilis n. sp., Jdaidites cultellus n. sp., Pericyclus tortuosus n. sp., Pericyclus circulus n. sp., Pericyclus trochus n. sp., Pericyclus intercisus n. sp., Nodopericyclus n. gen., Nodopericyclus circumnodosus n. sp., Nodopericyclus deficerus n. sp., Ammonellipsites serus n. sp., Helicocyclus formosus n. sp., Helicocyclus inornatus n. sp., Helicocyclus laxaris n. sp., Ouaoufilalites creber n. sp., family Temertassetiidae n. fam., Temertassetia n. gen., Temertassetia temertassetensis n. sp., Temertassetia secunda n. sp., Temertassetia decorata n. sp., Temertassetia coarta n. sp., Jerania n. gen., Jerania jeranensis n. sp., Jerania sicilicula n. sp., Jerania pusillens n. sp., Jerania subvexa n. sp., Jerania persimilis n. sp., Kusinia n. gen., Kusinia falcifera n. sp., Bouhamedites insalahensis n. sp., Muensteroceras subparallelum n. sp., Muensteroceras multitudum n. sp., Follotites n. gen., Follotites folloti n. sp., Follotites stelus n. sp., Follotites flexus n. sp., family Rotopericyclidae n. fam., Eurites permutus n. sp., Eurites doliaris n. sp., Mouydiria n. gen., Mouydiria mouydirensis n. sp., Mouydiria scutula n. sp., Rotopericyclus kaufmanni n. sp., Rotopericyclus rathi n. sp., Rotopericyclus wendti n. sp., Rotopericyclus lubesederi n. sp., subfamily Dzhaprakoceratinae n. subfam., Dzhaprakoceras punctum n. sp., Dzhaprakoceras amplum n. sp., Dzhaprakoceras vergum n. sp., Dzhaprakoceras biconvexum n. sp., Progoniatitinae n. subfam., Progoniatites uncus n. sp., Progoniatites pilus n. sp., Progoniatites paenacutus n. sp., Progoniatites globulus n. sp., Habadraitinae n. subfam., Habadraites n. gen., Habadraites weyeri n. sp., Habadraites supralatus n. sp., Primogoniatites n. gen., Primogoniatites fundator n. sp., Antegoniatitinae n. subfam., Antegoniatites n. gen., and Antegoniatites anticiparis n. sp.. The ammonoids occur in three successive assemblages and are the richest ammonoid faunas of the time interval worldwide.
\end{abstract}

\section{Introduction}

The Middle and early Late Tournaisian was regarded for a long time as an example of a period of low-diversity in the evolutionary history of the Ammonoidea (Konovalova 2005). At the beginning of the 21 st century, for instance, only about 25 species were known from the early Late Tournaisian, and most of the assemblages were rather poor in species numbers. The discovery of an ammonoid fauna of this age with eleven new species in the Anti-Atlas of Morocco, however, showed that there is a potential for a much more detailed overview of the ammonoid evolution of that time interval (Korn et al. 2003a).

\footnotetext{
* Corresponding author
} 
Middle and Late Tournaisian ammonoids are known from many places in the world, but occur often in lowdiversity assemblages. An exception is the terminal Tournaisian Erdbach Limestone of Germany (Holzapfel 1889; Schindewolf 1951), from which comparatively species-rich occurrences have been described. Timeequivalents of this fauna are also very diverse, as seen in the occurrences of Kyrgyzstan (Librovitch 1927; Popov 1965, 1968) and North Russia (Kusina 1980), for instance.

Early Late Tournaisian assemblages are much smaller, and are limited in their geographic distribution. They are known from the classic occurrences in the Calcaire de Calonne of Belgium (de Koninck 1844, 1880; Delépine 1940), the 'Carboniferous Limestone' of Ireland (Crick 1899; Foord 1901, 1903), and the Rockford Limestone as well as the Marshall Sandstone of the North American Midcontinent (Hall 1860; Miller \& Collinson 1951; Miller \& Garner 1955). An outstanding site is the Borden Formation of Kentucky, which yielded well-preserved ammonoids from three successive faunal complexes (Work \& Mason 2003, 2004, 2005).

While Early Tournaisian (Ebbighausen et al. 2004; Bockwinkel \& Ebbighausen 2006; Ebbighausen \& Bockwinkel 2007) and Late Viséan (Korn et al. 1999, 2007; Klug et al. 2006; Korn \& Ebbighausen 2008) ammonoid Faunas from North Africa have been outlined in several monographs, the state of knowledge of middle or early Late Tournaisian ammonoids from that region is still limited. A rich early Late Tournaisian fauna was recently described by Korn et al. (2003a, 2005, 2007) from Bouhamed and Jdaid in the Anti-Atlas of Morocco, being with twelve species the most diverse assemblage known so far from this time unit with the genera Irinoceras, Triimitoceras, Pericyclus, Orthocyclus, Helicocyclus, Jerania, Muensteroceras, Mouydiria, Progoniatites, Becanites, and Merocanites. In contrast to most of the other places, where the specimens occur in calcareous sedimentary rocks, the assemblage from Bouhamed is composed of shales, in which the specimens are preserved as limonitic steinkerns.

Ammonoids of early Late Tournaisian age have been known from the Mouydir in Algeria for decades. Termier \& Termier (1950) figured 'Pericyclus rotuliformis' (= Rotopericyclus kaufmanni n. sp.) and 'Pericyclus dilatatus' (= Pericyclus trochus n. sp.), collected in the course of oil exploration near Hassi Habadra in the Mouydir. Follot $(1951,1952,1953)$ published a fossil list of an occurrence at Oued Temertasset in the Mouydir, in which he enumerated several goniatite taxa, among them the nomen nudum Pericycloides (which was renamed by Korn et al. 2003a into Progoniatites). A description of Follot's specimens, however, has unfortunately never been published, and Follot's (1952, pl. 3) schematic drawings of some specimens are not clear enough to allow detailed examination. Short reports on the ammonoid faunas were later provided by Conrad (1966, 1967). Pareyn \& Conrad (1968) figured and de- scribed some individuals of Progoniatites, which probably came from the same locality, under the name Goniatites cf. crenistria. Later, Conrad (1984) presented a number of well-preserved specimens from the Oued Temertasset and other localities. These belong to various genera such as Imitoceras, Rotopericyclus, Pericyclus, Jerania, and Progoniatites.

Considerably rich early Late Tournaisian ammonoid faunas were reported from the following geographic areas:

Indiana - The fauna of the Rockford Limestone (Hall 1860; Miller 1891; Gutschick \& Treckman 1957) shows some resemblance with the newly described assemblages. The Rockford fauna is composed of the genera Imitoceras, Gattendorfia, Prodromites, Muensteroceras, and Protocanites.

Kentucky - Of the three Osagean ammonoid assemblages (Work \& Mason 2003, 2004, 2005), it is particularly the Nada Member of the Borden Formation that is similar to the occurrences at Oued Temertasset. The fauna contains Polaricyclus and Winchelloceras (Work \& Mason 2003).

Ireland - Of the rich ammonoid fauna described by Crick (1899) and Foord (1901, 1903), particularly the material from St. Doulagh's (Co. Dublin) which shows a close resemblance with a distinct horizon within the Argiles de Teguentour. The species (names given by Foord and revised names) known from this locality are the following:
Pericyclus Foordi
= Rotopericyclus foordi
Pericyclus subplicatilis = Rotopericyclus subplicatilis
Pericyclus Bailyi = Rotopericyclus bailyi
Pericyclus rotuliformis = Rotopericyclus rotuliformis
Glyphioceras (Beyrichoceras) corpulentum
$=$ Eurites corpulentus
Glyphioceras (Beyrichoceras) truncatum

= Dzhaprakoceras hibernicum

Belgium - Two rock formations yielded ammonoids of early Late Tournaisian age, the Calcaire de Vaulx and the Calcaire de Calonne (de Koninck 1844, 1880; Delépine 1940).

The Calcaire de Vaulx yielded the following species (determinations by Delépine and revised names):
Acrocanites tornacensis = Acrocanites tornacensis
Muensteroceras rotella = Xinjiangites rotella
Muensteroceras perspectivum $=$ Xinjiangites perspectivus
"Goniatites" (Pericyclus ?) crenulatus = indet.
Protocanites lyoni= Becanites tornacensis

The Calcaire de Calonne yielded the following species (determinations by Delépine and revised names):
Imitoceras rotatorium
$=$ Imitoceras rotatorium
Pericyclus princeps
Pericyclus ryckholti
$=$ Pericyclus princeps
Muensteroceras rotella
= Bouhamedites ryckholt
$=$ Xinjiangites rotella 
Pericyclus princeps var. multiplicatus

$$
=\text { Temertassetia multiplicata }
$$

Muensteroceras complanatum $=$ Jerania complanata

Pericyclus divisus

$=$ Progoniatites divisus

The faunal lists show that the Calcaire de Vaulx has some resemblance with the lower assemblage described by Korn et al. (2010a) from the Grès de Kahla supérieur of Timimoun. The Calcaire de Calonne is, with its composition of genera, very similar to the assemblages from the Argiles de Teguentour at Oued Temertasset described herein.

Thuringia - Phosphatic nodules in the Rußschiefer near Zadelsdorf yielded ammonoids (Schindewolf 1922, 1926, 1939), which at least partly can be regarded as time equivalents of the fauna of the Argiles de Teguentour. Schindewolf listed the following species:

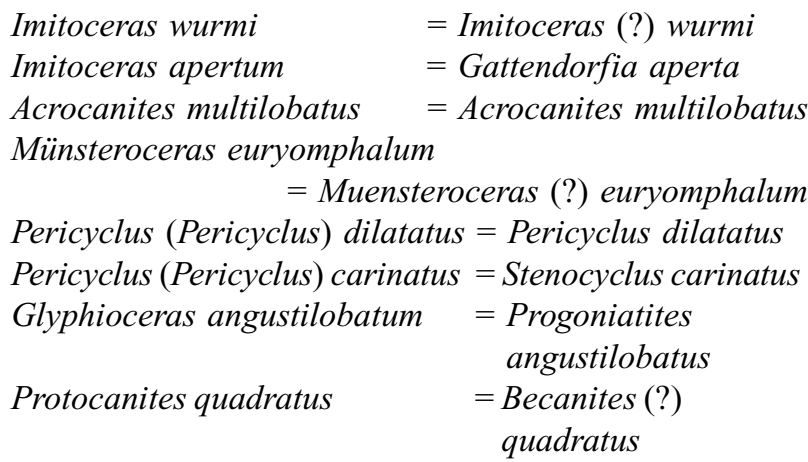

Pay-Khoy and Vaigach Isles - Kusina (2000) described four species from four genera, Paraqiannanites, Pericyclus, Orthocyclus, and 'Zhifangoceras' (the species described here belongs in fact to Progoniatites). Pericyclus and Progoniatites suggest a correlation with the Argiles de Teguentour.

South Urals - The small fauna consisting of Polaricyclus and Orthocyclus (Kusina 2000) may be a time equivalent of the Argiles de Teguentour.

\section{Geographic and geological setting}

The Mouydir is a desert region in the Central Sahara, located south-east of the town In Salah in South Algeria (Fig. 1). It is characterised by gently folded Palaeozoic rocks, which are strongly weathered and partly covered by a Cainozoic cover and sand dunes. The Mouydir belongs to a sedimentary basin on the northern part of the Sahara Craton, which means that it has a North Gondwana palaeogeographic position (Conrad 1984; Wendt et al. 2009).

The Carboniferous rock succession begins with a sandstone complex (Grès du Khenig), which shows an alteration of fine to medium-grained, often crossbedded sandstones and silty shales. Its total thickness ranges between 85 and 310 metres (Conrad 1984; Wendt et al. 2009), unfortunately its stratigraphy is not well known. Most likely the Devonian-Carboniferous boundary lies within this formation.
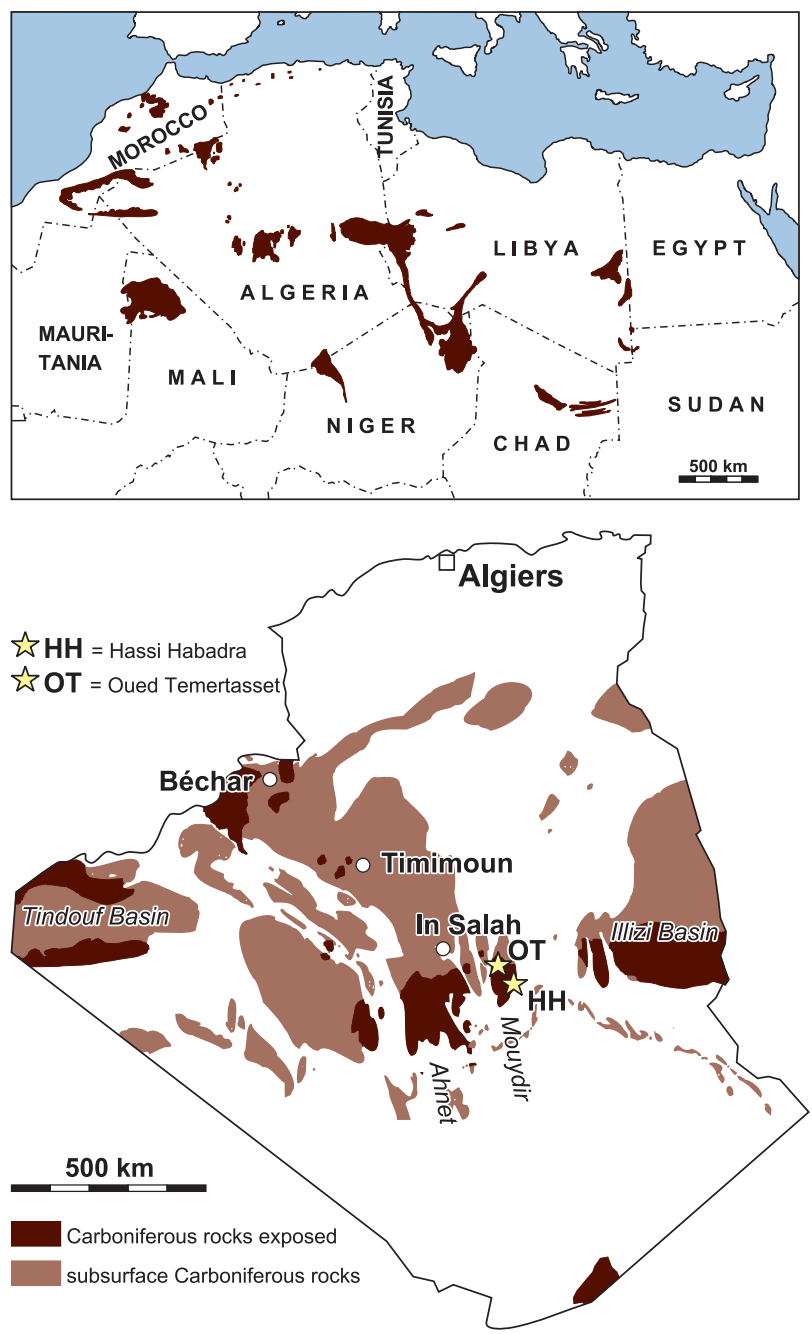

Figure 1. The outcrop of Palaeozoic rocks in northern Africa and the geographic position (marked by an asterisk) of the localities of the Argiles de Teguentour of Oued Temertasset.

The overlying Argiles de Teguentour are not very well exposed due to strong weathering; this formation yielded the ammonoid fauna described in this monograph. Its thickness is difficult to estimate, but may attain 200 metres at Oued Temertasset, of which only the basal 70 metres are fossiliferous (Wendt et al. 2009). The claystones are strongly weathered, and only a few places allow a spot-like insight into the lithological succession. Therefore, all the faunas were collected on the surface. Thin limestone intercalations occur at the base of the formation, but these are almost always small lenticular bodies of limestone or only sporadically and irregularly occurring sideritic nodules. Almost always, they are micritic in their internal composition.

Above the Argiles de Teguentour follows another sandstone unit of about 200 metres in thickness, the Grès de Tibaradine, whose upper part constitutes a prominent sandstone ridge. This is overlain by the Dalle des Iridet, a limestone rather rich in fossils, particularly in brachiopods, rugose corals, ammonoids (Korn et al. 2010b), and nautiloids. 


\section{Material}

The material described in this monograph was collected in an area extending for about 40 kilometres, 140 to 180 kilometres east-southeast of the town In Salah (South Algeria, Central Sahara). The localities are located in the vicinity of Oued Temertasset, a dry valley eight kilometres east of the conspicuous mountain chain of the El Jerane. The Argiles de Teguentour, from which the material was collected, is poorly exposed due to intensive weathering. Some outcrops of this formation were investigated, but these proved difficult to sample for macrofossils because of the rarity of organic remains. Therefore all the material was collected on the surface. It was assembled during four field sessions, 1997, 1999, and 2001 by Jobst Wendt and colleagues (Tübingen), and in 2002 by the authors in co-operation with Dieter Weyer (Berlin). More than 7,200 specimens were examined.

The material collected by the authors of this publication was, at those places where no significant reworking by transport could be expected, collected from small sample areas. In some places, a sampling of various succeeding horizons was possible because of their separa- tion by small ridges in the topography of the desert. This enabled the construction of a stratigraphic scheme for these faunas and by this method, three faunal units could be separated. Nearly all of the less rigorously collected samples can be placed rather precisely in this scheme and appear to support it.

Nearly all of the material from the Argiles de Teguentour is preserved as limonitic internal moulds. There are only two exceptions, (1) rare carbonate nodules, which occasionally contain a rather diverse ammonoid fauna, and (2) a particularly striking horizon with large specimens (up to 10 centimetres across) of Rotopericyclus.

Simultaneously with the ammonoid collections, conodont samples were taken from carbonate horizons. Unfortunately, most of them were not productive, but one sample (MOU-C3) yielded a fauna of the base of the anchoralis Zone (determinations by Z. Belka, Poznan). All the accompanying fauna from the Argiles de Teguentour were also sampled; further elements are brachiopods, bivalves, gastropods, nautiloids, and trilobites (Hahn et al. 2004).

The material comes from the following localities (material of samples with the prefix A was collected by Jobst Wendt and colleagues, Tübingen); material of samples with the prefix MOU was collected by the authors and D. Weyer in 2002):

Locality and sample A-232, Hassi Habadra, $177 \mathrm{~km}$ east-southeast of In Salah $\left(26.5116^{\circ} \mathrm{N} ; 4^{-1110^{\circ}} \mathbf{E}\right)$ :

Helicocyclus inornatus n. sp.

Muensteroceras multitudum n. sp.

Eurites permutus n. sp.

Eurites doliaris n. sp.

Kusinia falcifera $\mathrm{n}$. sp.
37 specimens (MB.C.18715.1-37)
42 specimens (MB.C.18716.1-42)
28 specimens (MB.C.18717.1-28)
2 specimens (MB.C.18718.1-2)
24 specimens (MB.C.18719.1-24)

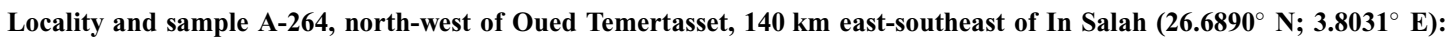

Imitoceras strictum $\mathrm{n}$. $\mathrm{sp}$.

Triimitoceras tantulum n. sp.

Pericyclus circulus n. sp.

Pericyclus trochus n. sp.

Pericyclus intercisus n. sp.

Temertassetia decorata $\mathrm{n}$. $\mathrm{sp}$.

Jerania jeranensis n. sp.

Jerania sicilicula $\mathrm{n}$. $\mathrm{sp}$.

Jerania persimilis $\mathrm{n}$. $\mathrm{sp}$.

Jerania subvexa $\mathrm{n}$. sp.

Dzhaprakoceras vergum $\mathrm{n}$. sp.

Progoniatites uncus n. sp.

Progoniatites pilus n. sp.

7 specimens (MB.C.18720.1-7)

1 specimen (MB.C.18721)

14 specimens (MB.C.18722.1-14)

4 specimens (MB.C.18723.1-4)

8 specimens (MB.C.18724.1-8)

1 specimen (MB.C.18725)

8 specimens (MB.C.18726.1-8)

2 specimens (MB.C.18727.1-2)

1 specimen (MB.C.18728)

1 specimen (MB.C.18729)

85 specimens (MB.C.18730.1-85)

1 specimen (MB.C.18731)

8 specimens (MB.C.18732.1-8)

Locality and sample A-320/5, south of Oued Temertasset $\left(26.6116^{\circ} \mathrm{N}\right.$; $\left.3.8362^{\circ} \mathrm{E}\right)$; see Wendt et al. (2009, fig. 8):

Ouaoufilalites creber n. sp.

Follotites folloti n. sp.

Follotites flexus n. sp.

Mouydiria mouydirensis n. sp.

Dzhaprakoceras biconvexum $\mathrm{n}$. $\mathrm{sp}$.
32 specimens (MB.C.18733.1-32)

5 specimens (MB.C.18734.1-5)

7 specimens (MB.C.18735.1-7)

21 specimens (MB.C.18736.1-21)

85 specimens (MB.C.18737.1-85)

Locality and sample A-320/7; horizon above sample A-320/5:

Rotopericyclus kaufmanni $\mathrm{n}$. sp.

Rotopericyclus rathi $\mathrm{n}$. $\mathrm{sp}$.

Rotopericyclus wendti $\mathrm{n}$. sp.

Rotopericyclus lubesederi $\mathrm{n}$. sp.

Rotopericyclus? sp.

Locality and sample A-321, as sample A-264:

Imitoceras dimidium $\mathrm{n}$. $\mathrm{sp}$.

Pericyclus circulus n. sp.

Pericyclus trochus n. sp.

Pericyclus intercisus n. sp.

Helicocyclus formosus n. $\mathrm{sp}$.

Temertassetia coarta $\mathrm{n}$. sp.

Jerania sicilicula $\mathrm{n}$. $\mathrm{sp}$.

4 specimens (MB.C.18738.1-4)

6 specimens (MB.C.18739.1-6)

47 specimens (MB.C.18740.1-47)

12 specimens (MB.C.18741.1-12)

4 specimens (MB.C.18741.1-4)

13 specimens (MB.C.18742.1-13)

12 specimens MB.C.18743.1-12)

27 specimens (MB.C.18744.1-27)

20 specimens (MB.C.18745.1-20)

1 specimen (MB.C.18746)

2 specimens (MB.C.18747.1-2)

4 specimens (MB.C.18748.1-4)

Jerania persimilis $\mathrm{n}$. $\mathrm{sp}$.

25 specimens (MB.C.18749.1-25)

Progoniatites pilus n. sp.

2 specimens (MB.C.18750.1-2) 
Locality and sample A-330/17, north of Ain Tiouendjiguine $\left(26.9315^{\circ} \mathrm{N} ; 3^{25826}{ }^{\circ} \mathrm{E}\right)$ :

Pericyclus circulus n. sp.

3 specimens (MB.C.18751.1-3)

Progoniatites pilus $\mathrm{n}$. sp.

3 specimens (MB.C.18752.1-3)

Locality and sample MOU-A, north-west of Oued Temertasset $\left(26.6909^{\circ} \mathrm{N} ; 3^{\circ .8038^{\circ}} \mathrm{E}\right)$; bulk sample of various horizons:

Imitoceras dimidium n. $\mathrm{sp}$.

Imitoceras strictum $\mathrm{n}$. sp.

Acrocanites disparilis n. sp.

Pericyclus circulus n. sp.

Pericyclus trochus n. sp.

Pericyclus intercisus n. sp.

Ouaoufilalites creber n. sp.

Temertassetia temertassetensis $\mathrm{n}$. $\mathrm{sp}$.

Temertassetia coarta $\mathrm{n}$. sp.

Jerania jeranensis n. $\mathrm{sp}$.

Jerania sicilicula n. sp.

Jerania pusillens $\mathrm{n}$. sp.

Jerania subvexa $\mathrm{n}$. sp.

Bouhamedites insalahensis $\mathrm{n} . \mathrm{sp}$.

Muensteroceras subparallelum $\mathrm{n}$. $\mathrm{sp}$.

Follotites folloti n. sp.

Follotites stelus n. sp.

Follotites flexus n. sp.

Dzhaprakoceras vergum n. sp.

Dzhaprakoceras amplum n. $\mathrm{sp}$

Dzhaprakoceras biconvexum n. sp.

Progoniatites uncus n. sp.

Progoniatites globulus n. sp.

Habadraites weyeri $\mathrm{n}$. sp.

Primogoniatites fundator $\mathrm{n}$. $\mathrm{sp}$.

Becanites inflateralis Korn et al., 2010
6 specimens (MB.C.18753.1-6)

7 specimens (MB.C.18754.1-7)

1 specimen (MB.C.18755)

28 specimens (MB.C.18756.1-28)

59 specimens (MB.C.18757.1-59)

11 specimens (MB.C.18758.1-11)

1 specimen (MB.C.18759)

3 specimens (MB.C.18760.1-3)

5 specimens (MB.C.18761.1-5)

3 specimens (MB.C.18762.1-3)

31 specimens (MB.C.18763.1-31)

2 specimens (MB.C.18764.1-2)

2 specimens (MB.C.18765.1-2)

1 specimen (MB.C.18766)

15 specimens (MB.C.18767.1-15)

2 specimens (MB.C.18768.1-2)

5 specimens (MB.C.18769.1-5)

4 specimens (MB.C.18770.1-4)

23 specimens (MB.C.18771.1-23)

1 specimen (MB.C.18772)

7 specimens (MB.C.18773.1-7)

11 specimens (MB.C.18774.1-11)

4 specimens (MB.C.18775.1-4)

3 specimens (MB.C.18776.1-3)

10 specimens (MB.C.18777.1-10)

3 specimens (MB.C.18778.1-3)

Locality and sample MOU-B, north-west of Oued Temertasset $\left(26.7007^{\circ} \mathrm{N} ; 3.7978^{\circ}\right.$ E); bulk sample of various horizons $($ B0-B9 as mentioned in the text are subsamples):

Imitoceras dimidium n. $\mathrm{sp}$.

Pericyclus circulus n. sp.

Pericyclus trochus n. sp.

Pericyclus intercisus n. sp.

Nodopericyclus circumnodosus n. $\mathrm{sp}$.

Temertassetia temertassetensis $\mathrm{n}$. $\mathrm{sp}$.

Temertassetia secunda $\mathrm{n}$. sp.

Temertassetia decorata $\mathrm{n}$. sp.

Temertassetia coarta $\mathrm{n}$. sp.

Jerania jeranensis n. sp.

Jerania sicilicula $\mathrm{n}$. $\mathrm{sp}$.

Jerania persimilis n. sp.

Muensteroceras subparallelum $\mathrm{n}$. $\mathrm{sp}$.

Follotites folloti n. sp.

Follotites stelus n. sp.

Follotites flexus n. sp.

Eurites permutus n. sp.

Mouydiria scutula $\mathrm{n}$. sp.

Dzhaprakoceras vergum n. sp.

Dzhaprakoceras amplum n. sp.

Progoniatites uncus n. sp.

Progoniatites pilus n. sp.

Progoniatites paenacutus n. sp.

Progoniatites globulus n. sp.

Habadraites supralatus n. sp.

Primogoniatites fundator $\mathrm{n}$. sp.

Becanites inflateralis Korn et al., 2010
14 specimens (MB.C.18779.1-14)

27 specimens (MB.C.18780.1-27)

51 specimens (MB.C.18781.1-51)

21 specimens (MB.C.18782.1-21)

3 specimens (MB.C.18783.1-3)

14 specimens (MB.C.18784.1-14)

4 specimens (MB.C.18785.1-4)

12 specimens (MB.C.18786.1-12)

21 specimens (MB.C.18787.1-21)

4 specimens (MB.C.18788.1-4)

19 specimens (MB.C.18789.1-19)

3 specimens (MB.C.18790.1-3)

13 specimens (MB.C.18791.1-13)

5 specimens (MB.C.18792.1-5)

12 specimens (MB.C.18793.1-12)

2 specimens (MB.C.18794.1-2)

1 specimen (MB.C.18795)

1 specimen (MB.C.18796)

11 specimens (MB.C.18797.1-11)

4 specimens (MB.C.18798.1-4)

10 specimens (MB.C.18799.1-10)

7 specimens (MB.C.18800.1-7)

3 specimens (MB.C.18801.1-3)

2 specimens (MB.C.18802.1-2)

1 specimen (MB.C.18803)

23 specimens (MB.C.18804.1-23)

1 specimen (MB.C.18805) 
Locality and sample MOU-C1, immediately south of Oued Temertasset $\left(26.6178^{\circ} \mathrm{N} ;{3.8392^{\circ}}^{\mathrm{E}}\right)$; sample from one nodule horizon, Helicocyclus-Ouaoufilalites Assemblage:

Rotopericyclus kaufmanni $\mathrm{n}$. sp.

Rotopericyclus rathi $\mathrm{n}$. sp.

Rotopericyclus wendti $\mathrm{n}$. sp.

Rotopericyclus lubesederi $\mathrm{n}$. $\mathrm{sp}$.

Rotopericyclus? sp.
13 specimens (MB.C.18806.1-13)

7 specimens (MB.C.18807.1-7)

81 specimens (MB.C.18808.1-81)

34 specimens (MB.C.18809.1-34)

5 specimens (MB.C.18741.1-5)

Locality and sample MOU-C2, shales around the nodular horizon; Helicocyclus-Ouaoufilalites Assemblage:

Triimitoceras tantulum n. sp.

1 specimen (MB.C.18811)

Kusinia falcifera $\mathrm{n}$. sp.

303 specimens (MB.C.18812.1-303)

Muensteroceras multitudum n. sp.

500 specimens (MB.C.18813.1-500)

Eurites permutus n. sp.

137 specimens (MB.C.18814.1-137)

Eurites doliaris n. sp.

18 specimens (MB.C.18815.1-18)

Rotopericyclus lubesederi $\mathrm{n}$. sp.

1 specimen (MB.C.18816)

Locality and sample MOU-C3, carbonate nodules approximately 8 m below sample MOU-C1; Helicocyclus-Ouaoufilalites Assemblage:

Ammonellipsites serus $\mathrm{n}$. sp.

4 specimens (MB.C.18817.1-4)

Muensteroceras multitudum n. sp.

5 specimens (MB.C.18818.1-5)

Eurites permutus n. sp.

5 specimens (MB.C.18819.1-5)

Eurites doliaris n. sp.

2 specimens (MB.C.18820.1-2)

Locality and sample MOU-C4, approximately 20 m below sample MOU-C1; Upper Pericyclus-Progoniatites Assemblage:

Imitoceras dimidium $\mathrm{n} . \mathrm{sp}$.

Acrocanites disparilis $\mathrm{n}$. $\mathrm{sp}$.

Jdaidites cultellus $\mathrm{n}$. sp.

29 specimens (MB.C.18821.1-29)

1 specimen (MB.C.18822)

1 specimen (MB.C.18823)

Pericyclus tortuosus n. sp.

1 specimen (MB.C.18824)

Pericyclus circulus n. sp.

Temertassetia secunda $\mathrm{n}$. sp.

1 specimen (MB.C.18825)

Muensteroceras subparallelum n. $\mathrm{sp}$.

1 specimen (MB.C.18826)

Eurites permutus n. sp.

95 specimens (MB.C.18827.1-95)

Dzhaprakoceras biconvexum $\mathrm{n}$. $\mathrm{sp}$.

1 specimen (MB.C.18828)

Habadraites weyeri $\mathrm{n}$. sp.

1 specimen (MB.C.18829)

1 specimen (MB.C.18830)

Locality and sample MOU-C5, horizon near sample MOU-C1; Helicocyclus-Ouaoufilalites Assemblage:

Helicocyclus inornatus n. sp.

Ouaoufilalites creber n. sp.

5 specimens (MB.C.18831.1-5)

1 specimen (MB.C.18832)

Kusinia falcifera $\mathrm{n}$. sp.

17 specimens (MB.C.18833.1-17)

Muensteroceras multitudum n. sp.

50 specimens (MB.C.18834.1-50)

Eurites permutus n. sp.

20 specimens (MB.C.18835.1-20)

Dzhaprakoceras biconvexum n. sp.

1 specimen (MB.C.18836)

Progoniatites paenacutus n. sp.

1 specimen (MB.C.18837)

Locality and sample MOU-C undifferentiated; contains elements of the Lower Pericyclus-Progoniatites Assemblage and the HelicocyclusOuaoufilalites Assemblage:

Imitoceras dimidium $\mathrm{n}$. sp.

Imitoceras strictum $\mathrm{n}$. $\mathrm{sp}$.

Triimitoceras tantulum n. sp.

Acrocanites disparilis n. sp.

Nodopericyclus deficerus n. sp.

Helicocyclus inornatus n. sp.

Helicocyclus laxaris n. sp.

Ouaoufilalites creber n. sp.

Jerania subvexa $\mathrm{n}$. sp.

Kusinia falcifera $\mathrm{n}$. sp.

Muensteroceras multitudum n. sp.

Eurites permutus n. sp.

Eurites doliaris n. sp.

Dzhaprakoceras vergum $\mathrm{n}$. $\mathrm{sp}$.

Dzhaprakoceras biconvexum $\mathrm{n}$. sp.
10 specimens (MB.C.18838.1-10)

3 specimens (MB.C.18839.1-3)

1 specimen (MB.C.18840)

1 specimen (MB.C.18841)

1 specimen (MB.C.18842)

5 specimens (MB.C.18843.1-5)

1 specimen (MB.C.18844)

1 specimen (MB.C.18845)

58 specimens (MB.C.18846.1-58)

10 specimens (MB.C.18847.1-10)

98 specimens (MB.C.18848.1-98)

25 specimens (MB.C.18849.1-25)

6 specimens (MB.C.18850.1-6)

54 specimens (MB.C.18851.1-54)

7 specimens (MB.C.18852.1-7)

Locality and sample MOU-D0, $1 \mathrm{~km}$ south of locality $\operatorname{MOU}-\mathrm{C}\left(26.6066^{\circ} \mathrm{N} ; 3.8389^{\circ} \mathrm{E}\right)$ :

Imitoceras dimidium n. sp.

Imitoceras strictum $\mathrm{n}$. sp.

Acrocanites disparilis n. sp.

3 specimens (MB.C.18853.1-3)

1 specimen (MB.C.18854)

1 specimen (MB.C.18855) 
Pericyclus circulus n. sp.

Jerania subvexa $\mathrm{n}$. sp.

Dzhaprakoceras vergum $\mathrm{n}$. sp.
1 specimen (MB.C.18856)

13 specimens (MB.C.18857.1-13)

83 specimens (MB.C.18858.1-83)

Locality and sample MOU-D1; horizon above sample MOU-D0; Upper Pericyclus-Progoniatites Assemblage: Imitoceras dimidium n. sp. Imitoceras strictum $\mathrm{n}$. $\mathrm{sp}$. 48 specimens (MB.C.18859.1-48)

9 specimens (MB.C.18860.1-9)

Acrocanites disparilis n. sp.

4 specimens (MB.C.18861.1-4)

Pericyclus circulus n. sp.

Pericyclus trochus n. sp.

Pericyclus intercisus n. sp.

Temertassetia temertassetensis $\mathrm{n}$. sp.

Temertassetia secunda $\mathrm{n}$. sp.

Temertassetia decorata $\mathrm{n}$. sp.

Temertassetia coarta $\mathrm{n}$. sp.

Jerania jeranensis n. $\mathrm{sp}$.

Jerania sicilicula $\mathrm{n}$. sp.

Jerania pusillens n. sp.

Jerania persimilis n. $\mathrm{sp}$.

Bouhamedites insalahensis n. sp.

Muensteroceras subparallelum $\mathrm{n}$. $\mathrm{sp}$.

118 specimens (MB.C.18862.1-118)

195 specimens (MB.C.18863.1-195)

180 specimens (MB.C.18864.1-180)

19 specimens (MB.C.18865.1-19)

3 specimens (MB.C.18866.1-3)

18 specimens (MB.C.18867.1-18)

90 specimens (MB.C.18868.1-90)

8 specimens (MB.C.18869.1-8)

10 specimens (MB.C.18870.1-10)

22 specimens (MB.C.18871.1-22)

6 specimens (MB.C.18872.1-6)

1 specimen (MB.C.18873)

89 specimens (MB.C.18874.1-89)

82 specimens (MB.C.18875.1-82)

29 specimens (MB.C.18876.1-29)

Progoniatites uncus n. sp.

Progoniatites pilus n. sp.

Progoniatites paenacutus n. sp.

Progoniatites globulus n. sp.

1 specimen (MB.C.18877)

3 specimens (MB.C.18878.1-3)

2 specimens (MB.C.18879.1-2)

1 specimen (MB.C.18880)

7 specimens (MB.C.18881.1-7)

Habadraites supralatus n. sp.

Primogoniatites fundator $\mathrm{n} . \mathrm{sp}$.

3 specimens (MB.C.18882.1-3)

1 specimen (MB.C.18883)

Locality and sample MOU-D2; horizon above sample MOU-D1; Upper Pericyclus-Progoniatites Assemblage:

Imitoceras dimidium $\mathrm{n}$. $\mathrm{sp}$.

Imitoceras strictum n. $\mathrm{sp}$.

Pericyclus circulus n. sp.

Pericyclus trochus n. sp.

Pericyclus intercisus n. sp.

Temertassetia temertassetensis $\mathrm{n}$. sp.

Temertassetia secunda $\mathrm{n}$. sp.

Temertassetia decorata $\mathrm{n}$. $\mathrm{sp}$.

Temertassetia coarta $\mathrm{n}$. sp.

Jerania jeranensis n. sp.

Jerania sicilicula $\mathrm{n}$. sp.

Jerania pusillens n. sp.

Jerania persimilis $\mathrm{n}$. $\mathrm{sp}$.

Muensteroceras subparallelum $\mathrm{n}$. sp.

Mouydiria mouydirensis $\mathrm{n}$. sp.

Mouydiria scutula n. sp.

Dzhaprakoceras amplum n. sp.

Dzhaprakoceras biconvexum n. sp.

Progoniatites uncus n. sp.

Progoniatites pilus n. sp.

Progoniatites paenacutus n. sp.

Habadraites supralatus n. sp.

Primogoniatites fundator $\mathrm{n}$. $\mathrm{sp}$.

35 specimens (MB.C.18884.1-35)

30 specimens (MB.C.18885.1-30)

80 specimens (MB.C.18886.1-80)

10 specimens (MB.C.18887.1-10)

6 specimens (MB.C.18888.1-6)

74 specimens (MB.C.18889.1-74)

27 specimens (MB.C.18890.1-27)

24 specimens (MB.C.18891.1-24)

10 specimens (MB.C.18892.1-10)

1 specimen (MB.C.18893)

45 specimens (MB.C.18894.1-45)

1 specimen (MB.C.18895)

1 specimen (MB.C.18896)

1 specimen (MB.C.18897)

1 specimen (MB.C.18898)

1 specimen (MB.C.18899)

2 specimens (MB.C.18900.1-2)

7 specimens (MB.C.18901.1-7)

15 specimens (MB.C.18902.1-15)

12 specimens (MB.C.18903.1-12)

3 specimens (MB.C.18904.1-3)

2 specimens (MB.C.18905.1-2)

1 specimen (MB.C.18906)

Locality and sample MOU-D3; horizon above sample MOU-D2; Upper Pericyclus-Progoniatites Assemblage:

Imitoceras dimidium $\mathrm{n}$. $\mathrm{sp}$.

Temertassetia temertassetensis $\mathrm{n}$. sp.

Temertassetia decorata $\mathrm{n}$. sp.

Jerania jeranensis $\mathrm{n}$. $\mathrm{sp}$.

Jerania sicilicula $\mathrm{n}$. sp.

Dzhaprakoceras amplum $\mathrm{n}$. $\mathrm{sp}$.

Progoniatites uncus $\mathrm{n}$. sp.

Primogoniatites fundator $\mathrm{n} . \mathrm{sp}$.
3 specimens (MB.C.18907.1-3)

4 specimens (MB.C.18908.1-4)

8 specimens (MB.C.18909.1-8)

4 specimens (MB.C.18910.1-4)

4 specimens (MB.C.18911.1-4)

13 specimens (MB.C.18912.1-13)

7 specimens (MB.C.18913.1-7)

2 specimens (MB.C.18914.1-2) 
Locality and sample MOU-E01, $500 \mathrm{~m}$ south of locality MOU-D $\left(26.6013^{\circ} \mathrm{N} ; 3_{.8393}^{\circ} \mathrm{E}\right)$; strictly recorded (the next following samples with the prefix MOU-E have been obtained in ascending order in the section; their stratigraphy will be outlined below):

Dzhaprakoceras vergum $\mathrm{n}$. sp.

9 specimens (MB.C.18915.1-9)

Locality and sample MOU-E02:

Dzhaprakoceras vergum $\mathrm{n}$. sp.

Acrocanites disparilis n. sp.

10 specimens (MB.C.18916.1-10)

1 specimen (MB.C.18917)

Locality and sample MOU-E03:

Imitoceras dimidium $\mathrm{n}$. $\mathrm{sp}$.

Imitoceras strictum $\mathrm{n}$. $\mathrm{sp}$.

Acrocanites disparilis n. $\mathrm{sp}$.

Jerania subvexa $\mathrm{n}$. sp.

Dzhaprakoceras vergum $\mathrm{n}$. $\mathrm{sp}$.

Habadraites weyeri $\mathrm{n} . \mathrm{sp}$.

Habadraites supralatus n. sp.

Locality and sample MOU-E04:

Imitoceras dimidium $\mathrm{n}$. $\mathrm{sp}$.

Pericyclus circulus $\mathrm{n}$. sp.

Jerania sicilicula $\mathrm{n}$. sp.

Dzhaprakoceras vergum $\mathrm{n}$. $\mathrm{sp}$.

9 specimens (MB.C.18918.1-9)

7 specimens (MB.C.18919.1-7)

1 specimen (MB.C.18920)

16 specimens (MB.C.18921.1-16)

56 specimens (MB.C.18922.1-56)

11 specimens (MB.C.18923.1-11)

1 specimen (MB.C.18924)

6 specimens (MB.C.18925.1-6)

6 specimens (MB.C.18926.1-6)

1 specimen (MB.C.18927)

12 specimens (MB.C.18928.1-12)

Locality and sample MOU-E05:

Pericyclus circulus $\mathrm{n}$. sp.

Pericyclus intercisus n. sp.

Dzhaprakoceras vergum $\mathrm{n}$. sp.

Becanites inflateralis Korn et al., 2010

1 specimen (MB.C.18929)

8 specimens (MB.C.18930.1-8)

1 specimen (MB.C.18931)

1 specimen (MB.C.18932)

Locality and sample MOU-E06:

Imitoceras dimidium $\mathrm{n}$. $\mathrm{sp}$.

Acrocanites disparilis n. sp.

Pericyclus trochus n. sp.

Temertassetia temertassetensis $\mathrm{n}$. $\mathrm{sp}$.

Temertassetia coarta $\mathrm{n}$. sp.

Jerania jeranensis $\mathrm{n}$. $\mathrm{sp}$.

Jerania sicilicula $\mathrm{n}$. sp.

Jerania persimilis $\mathrm{n}$. $\mathrm{sp}$.

Dzhaprakoceras vergum $\mathrm{n}$. sp.

Progoniatites uncus $\mathrm{n}$. sp.

Locality and sample MOU-E07:

Imitoceras dimidium $\mathrm{n}$. $\mathrm{sp}$.

Pericyclus circulus n. $\mathrm{sp}$.

Pericyclus trochus n. sp.

Pericyclus intercisus $\mathrm{n}$. sp.

Temertassetia temertassetensis $\mathrm{n}$. $\mathrm{sp}$.

Temertassetia secunda $\mathrm{n}$. sp.

Temertassetia decorata $\mathrm{n}$. sp.

Jerania jeranensis $\mathrm{n}$. sp.

Jerania sicilicula $\mathrm{n}$. sp.

Jerania persimilis $\mathrm{n}$. $\mathrm{sp}$.

Progoniatites uncus $\mathrm{n}$. sp.

Progoniatites pilus $\mathrm{n}$. sp.

Progoniatites paenacutus n. sp.

Habadraites supralatus n. sp.

5 specimens (MB.C.18933.1-5)

1 specimen (MB.C.18934)

10 specimens (MB.C.18935.1-10)

1 specimen (MB.C.18936)

7 specimens (MB.C.18937.1-7)

5 specimens (MB.C.18938.1-5)

7 specimens (MB.C.18939.1-7)

2 specimens (MB.C.18940.1-2)

7 specimens (MB.C.18941.1-7)

3 specimens (MB.C.18942.1-3)

76 specimens (MB.C.18943.1-76)

2 specimens (MB.C.18944.1-2)

4 specimens (MB.C.18945.1-4)

2 specimens (MB.C.18946.1-2)

41 specimens (MB.C.18947.1-41)

70 specimens (MB.C.18948.1-70)

58 specimens (MB.C.18949.1-58)

124 specimens (MB.C.18950.1-124)

62 specimens (MB.C.18951.1-62)

1 specimen (MB.C.18952)

32 specimens (MB.C.18953.1-32)

12 specimens (MB.C.18954.1-12)

1 specimen (MB.C.18955)

1 specimen (MB.C.18956)

Locality and sample MOU-E08:

Imitoceras dimidium $\mathrm{n}$. $\mathrm{sp}$.

Pericyclus intercisus $\mathrm{n}$. $\mathrm{sp}$.

Temertassetia decorata $\mathrm{n}$. sp.

Jerania jeranensis $\mathrm{n}$. sp.

Jerania sicilicula $\mathrm{n}$. sp.

Dzhaprakoceras vergum $\mathrm{n}$. sp.

Progoniatites uncus n. sp.

Progoniatites pilus n. sp.

Progoniatites paenacutus $\mathrm{n}$. sp.

Habadraites weyeri $\mathrm{n}$. sp.

Becanites inflateralis Korn et al., 2010

5 specimens (MB.C.18957.1-5)

15 specimens (MB.C.18958.1-15)

9 specimens (MB.C.18959.1-9)

14 specimens (MB.C.18960.1-14)

12 specimens (MB.C.18961.1-12)

7 specimens (MB.C.18962.1-7)

3 specimens (MB.C.18963.1-3)

1 specimen (MB.C.18964)

4 specimens (MB.C.18965.1-4)

1 specimen (MB.C.18966)

1 specimen (MB.C.18967) 


\section{Locality and sample MOU-E09:}

Pericyclus intercisus n. sp.

Jerania jeranensis n. sp.

Progoniatites pilus n. sp

Progoniatites paenacutus n. sp.

Habadraites weyeri n. sp.

Primogoniatites fundator $\mathrm{n}$. $\mathrm{sp}$.

Locality and sample MOU-E10:

Pericyclus trochus n. sp.

Pericyclus intercisus n. sp.

Nodopericyclus deficerus n. $\mathrm{sp}$.

Muensteroceras multitudum n. sp.

Eurites permutus n. sp.

Dzhaprakoceras punctum n. sp.

Dzhaprakoceras biconvexum n. sp.

Antegoniatites anticiparis n. sp.

Locality and sample MOU-E11:

Helicocyclus laxaris n. sp.

Ouaoufilalites creber n. sp.

Kusinia falcifera $\mathrm{n}$. sp.

Muensteroceras multitudum n. sp.

Eurites permutus n. sp.

Eurites doliaris n. sp.

Locality and sample MOU-E12:

Helicocyclus formosus n. $\mathrm{sp}$.

Helicocyclus inornatus n. sp.

Ouaoufilalites creber $\mathrm{n}$. sp.

Kusinia falcifera n. sp.

Muensteroceras multitudum $\mathrm{n}$. sp.

Eurites permutus n. sp.

Eurites doliaris n. sp.
8 specimens (MB.C.18968.1-8)

9 specimens (MB.C.18969.1-9)

1 specimen (MB.C.18070)

2 specimens (MB.C.18971.1-2)

1 specimen (MB.C.18972)

1 specimen (MB.C.18973)

1 specimen (MB.C.18974)

1 specimen (MB.C.18975)

1 specimen (MB.C.18976)

4 specimens (MB.C.18977.1-4)

2 specimens (MB.C.18978.1-2)

1 specimen (MB.C.18979)

2 specimens (MB.C.18980.1-2)

1 specimen (MB.C.18981)

2 specimens (MB.C.18982.1-2)

3 specimens (MB.C.18983.1-3)

8 specimens (MB.C.18984.1-8)

28 specimens (MB.C.18985.1-28)

7 specimens (MB.C.18986.1-5)

1 specimen (MB.C.18987)

9 specimens (MB.C.18988.1-9)

1 specimen (MB.C.18989)

4 specimens (MB.C.18990.1-4)

4 specimens (MB.C.18991.1-4)

29 specimens (MB.C.18992.1-29)

26 specimens (MB.C.18993.1-26)

1 specimen (MB.C.18994)

Locality and sample MOU-E13 $\left(26.6026^{\circ} \mathrm{N} ; 3^{2.8422^{\circ}} \mathrm{E}\right)$; highest sample of the succession:

Nodopericyclus deficerus $\mathrm{n}$. sp.

Ouaoufilalites creber $\mathrm{n}$. sp.

1 specimen (MB.C.18995)

2 specimens (MB.C.18996.1-2)

Muensteroceras multitudum n. sp.

1 specimen (MB.C.18997)

Locality and sample MOU-E undifferentiated:

Pericyclus trochus n. sp.

2 specimens (MB.C.18998.1-2)

Pericyclus intercisus n. sp.

4 specimens (MB.C.18999.1-4)

2 specimens (MB.C.19000.1-2)

Temertassetia temertassetensis $\mathrm{n}$. $\mathrm{sp}$.

Temertassetia decorata $\mathrm{n}$. sp.

7 specimens (MB.C.19001.1-7)

Muensteroceras subparallelum $\mathrm{n}$. $\mathrm{sp}$.

2 specimens (MB.C.19002-2)

6 specimens (MB.C.19003-6)

Follotites stelus n. sp.

3 specimens (MB.C.19004-3)

Locality and sample MOU-F, south-west of Oued Temertasset $\left(26.5945^{\circ}\right.$ N; 3.8606 E); Upper Pericyclus-Progoniatites Assemblage:

Imitoceras dimidium n. sp.

Pericyclus intercisus n. sp.

Ouaoufilalites creber n. sp.

6 specimens (MB.C.19005.1-6)

6 specimens (MB.C.19006.1-6)

Temertassetia decorata $\mathrm{n}$. $\mathrm{sp}$

Temertassetia coarta $\mathrm{n}$. sp.

1 specimen (MB.C.19007)

8 specimens (MB.C.19008.1-8)

2 specimens (MB.C.19009.1-2)

Jerania pusillens $\mathrm{n}$. sp.

1 specimen (MB.C.19010)

Jerania persimilis $\mathrm{n}$. $\mathrm{sp}$.

2 specimens (MB.C.19011.1-2)

Muensteroceras subparallelum $\mathrm{n}$. $\mathrm{sp}$.

3 specimens (MB.C.19012.1-3)

Mouydiria mouydirensis $\mathrm{n}$. $\mathrm{sp}$.

Dzhaprakoceras biconvexum n. sp.

6 specimens (MB.C.19013.1-6)

4 specimens (MB.C.19014.1-4)

Progoniatites uncus n. sp.

5 specimens (MB.C.19015.1-5)

Locality and sample MOU-G, west of Hassi Habadra $\left(26.5032^{\circ}\right.$ N; $3.9099^{\circ}$ E); Upper Pericyclus-Progoniatites Assemblage:

Pericyclus circulus n. sp.

Pericyclus trochus n. sp.

4 specimens (MB.C.19016.1-4)

Pericyclus intercisus n. $\mathrm{sp}$.

16 specimens (MB.C.19017.1-16)

Temertassetia coarta $\mathrm{n}$. sp.

11 specimens (MB.C.19018.1-11)

8 specimens (MB.C.19019.1-8) 
Jerania sicilicula $\mathrm{n}$. $\mathrm{sp}$.

Dzhaprakoceras vergum $\mathrm{n}$. $\mathrm{sp}$.
2 specimens (MB.C.19020.1-2)

2 specimens (MB.C.19021.1-2)

Locality and sample MOU-V, west of Hassi Habadra $\left(26.5047^{\circ} \mathrm{N}\right.$; $3.9081^{\circ}$ E); Lower Pericyclus-Progoniatites Assemblage: Imitoceras dimidium $\mathrm{n} . \mathrm{sp}$. Imitoceras strictum $\mathrm{n}$. $\mathrm{sp}$. Triimitoceras tantulum n. sp. Acrocanites disparilis n. sp. Pericyclus tortuosus n. $\mathrm{sp}$. Jerania subvexa $\mathrm{n}$. sp. Dzhaprakoceras vergum n. $\mathrm{sp}$. Progoniatites globulus n. sp. Habadraites weyeri $\mathrm{n}$. sp. Habadraites supralatus n. sp. Becanites inflateralis Korn et al., 2010

87 specimens (MB.C.19022.1-87)

4 specimens (MB.C.19023.1-4)

2 specimens (MB.C.19024.1-2)

52 specimens (MB.C.19025.1-52)

11 specimens (MB.C.19026.1-11)

88 specimens (MB.C.19027.1-88)

410 specimens (MB.C.19028.1-410)

3 specimens (MB.C.19029.1-3)

5 specimens (MB.C.19030.1-5)

2 specimens (MB.C.19031.1-2)

1 specimen (MB.C.19032)

Locality and sample MOU-X, south-east of Oued Temertasset $\left(26.5875^{\circ} \mathrm{N} ; \mathbf{3 . 8 6 1 7}^{\circ}\right.$ E); Helicocyclus-Ouaoufilalites Assemblage:

Nodopericyclus circumnodosus n. $\mathrm{sp}$.

Helicocyclus formosus n. sp.

Helicocyclus inornatus n. sp.

1 specimen (MB.C.19033)

6 specimens (MB.C.19034.1-6)

Helicocyclus laxaris n. sp.

Ouaoufilalites creber n. sp.

60 specimens (MB.C.19035.1-60)

19 specimens (MB.C.19036.1-19)

3 specimens (MB.C.19037.1-3)

Kusinia falcifera $\mathrm{n}$. sp.

81 specimens (MB.C.19038.1-81)

Muensteroceras multitudum n. sp.

Eurites permutus n. sp.

382 specimens (MB.C.19039.1-382)

Eurites doliaris n. sp.

106 specimens (MB.C.19040.1-106)

Rotopericyclus wendti n. sp.

41 specimens (MB.C.19041.1-41)

1 specimen (MB.C.19042)

Locality and sample MOU-Y, south of Oued Temertasset $\left(26.5820^{\circ} \mathrm{N}\right.$; $3^{\circ 519}{ }^{\circ}$ E); Helicocyclus-Ouaoufilalites Assemblage:

Nodopericyclus circumnodosus n. sp.

4 specimens (MB.C.19043.1-4)

Nodopericyclus deficerus n. sp.

Ouaoufilalites creber n. sp.

15 specimens (MB.C.19044.1-15)

1 specimen (MB.C.19045)

Kusinia falcifera $\mathrm{n}$. sp.

5 specimens (MB.C.19046.1-5)

Muensteroceras multitudum n. sp.

Eurites permutus n. sp.

31 specimens (MB.C.19047.1-31)

25 specimens (MB.C.19048.1-25)

Eurites doliaris n. sp.

19 specimens (MB.C.19049.1-19)

Dzhaprakoceras punctum n. sp.

Dzhaprakoceras biconvexum n. sp.

28 specimens (MB.C.19050.1-28)

8 specimens (MB.C.19051.1-8)

Antegoniatites anticiparis n. $\mathrm{sp}$.

19 specimens (MB.C.19052.1-19)

Locality and sample MOU-Z, south of Oued Temertasset, horizon below sample MOU-Y; Upper Pericyclus-Progoniatites Assemblage: Imitoceras dimidium n. sp.

Pericyclus circulus n. sp.

9 specimens (MB.C.19053.1-9)

17 specimens (MB.C.19054.1-17)

Pericyclus trochus n. sp.

Pericyclus intercisus $\mathrm{n}$. sp.

106 specimens (MB.C.19055.1-106)

Temertassetia coarta n. sp.

55 specimens (MB.C.19056.1-55)

Muensteroceras subparallelum $\mathrm{n}$. $\mathrm{sp}$.

33 specimens (MB.C.19057.1-33)

Progoniatites uncus n. sp.

43 specimens (MB.C.19058.1-43)

22 specimens (MB.C.19059.1-22)

Progoniatites globulus n. sp.

Habadraites weyeri $\mathrm{n}$. sp.

1 specimen (MB.C.19060)

1 specimen (MB.C.19061)

Becanites inflateralis Korn et al., 2010

1 specimen (MB.C.19062)

Locality and sample undifferentiated from the area of Oued Temertasset (bulk sample):

Imitoceras dimidium $\mathrm{n}$. $\mathrm{sp}$.

Imitoceras strictum $\mathrm{n}$. $\mathrm{sp}$.

Jdaidites cultellus n. sp.

Pericyclus circulus n. sp.

Pericyclus trochus n. sp.

Pericyclus intercisus n. $\mathrm{sp}$.

Nodopericyclus circumnodosus n. sp.

Ouaoufilalites creber n. sp.

Temertassetia temertassetensis $\mathrm{n}$. $\mathrm{sp}$.

Temertassetia decorata $\mathrm{n}$. sp.

Temertassetia coarta $\mathrm{n}$. sp.

Jerania persimilis $\mathrm{n}$. $\mathrm{sp}$.

Jerania subvexa $\mathrm{n}$. $\mathrm{sp}$.

Muensteroceras subparallelum n. $\mathrm{sp}$.

19 specimens (MB.C.19063.1-11)

2 specimens (MB.C.19064.1-2)

1 specimen (MB.C.19065)

18 specimens (MB.C.19066.1-18)

12 specimens (MB.C.19067.1-12)

15 specimens (MB.C.19068.1-15)

1 specimen (MB.C.19069)

6 specimens (MB.C.19070.1-6)

25 specimens (MB.C.19071.1-25)

4 specimens (MB.C.19072.1-4)

7 specimens (MB.C.19073.1-7)

30 specimens (MB.C.19074.1-30)

2 specimens (MB.C.19075.1-2)

6 specimens (MB.C.19076.1-6) 
Follotites folloti n. sp.

Mouydiria mouydirensis $\mathrm{n}$. $\mathrm{sp}$.

Dzhaprakoceras vergum n. sp.

Progoniatites uncus n. sp.

Progoniatites paenacutus n. sp.

\author{
1 specimen (MB.C.19077) \\ 2 specimens (MB.C.19078.1-2) \\ 22 specimens (MB.C.19079.1-22) \\ 2 specimens (MB.C.19080.1-2) \\ 1 specimen (MB.C.19081)
}

\section{Stratigraphy}

Ammonoid faunas of Late Tournaisian and Early to Middle Viséan age are often characterised by rather specific compositions, and time equivalent assemblages of neighbouring localities may significantly differ. Furthermore, Lazarus taxa are very common (Korn et al. 2005).

The ammonoid faunas from the Argiles de Teguentour are representative, in a global context, for the Pericyclus-Progoniatites Genus Zone and the newly proposed Helicocyclus-Ouaoufilalites Genus Zone (Fig. 2). The latter, however, is only represented by the occurrence of an early species of Ammonellipsites. The stratigraphic scheme for the North African occurrences of Early Carboniferous ammonoids proposed by Korn et al. (2007) included two faunal bands (assemblages) within this genus zone, i.e. the Kazakhstania-Acrocanites Assemblage (known from the Grès de Kahla supérieur near Timimoun; Korn et al. 2010a) at the base and the Pericyclus-Progoniatites Assemblage (known from the Oued Snaïgui Formation of Bouhamed in the Anti-Atlas; Korn et al. 2003a) in the upper part. The fauna from Bouhamed contains genera also known from Oued Temertasset, except for Irinoceras and Orthocyclus, which are not known from the Mouydir.

We can separate at least three major faunal complexes within the Pericyclus-Progoniatites Assemblage in the Argiles de Teguentour. These complexes can best be recognised in the successive samples MOU-E01 to MOU-E13 (and supported by some of the other samples), in ascending order:

Lower Pericyclus-Progoniatites Assemblage: Sample MOU-E01-MOU-E03 (and complimented by sample MOU-V): with the species Dzhaprakoceras vergum, Jerania subvexa, Pericyclus tortuosus, and Acrocanites disparilis, but without Progoniatites and Temertassetia.

Upper Pericyclus-Progoniatites Assemblage: Sample MOU-E04-MOU-E10: with the common genera Pericyclus, Progoniatites, Temertassetia, and Jerania, but without Ouaoufilalites and Helicocyclus.

Helicocyclus-Ouaoufilalites Assemblage: Sample MOU-E11-MOU-E13: with the genera Ouaoufilalites, Nodopericyclus, Mouydiria, Kusinia, Rotopericyclus, Ammonellipsites, and Helicocyclus.

Most of the other samples can easily be correlated with this simplified scheme, which can probably be refined.

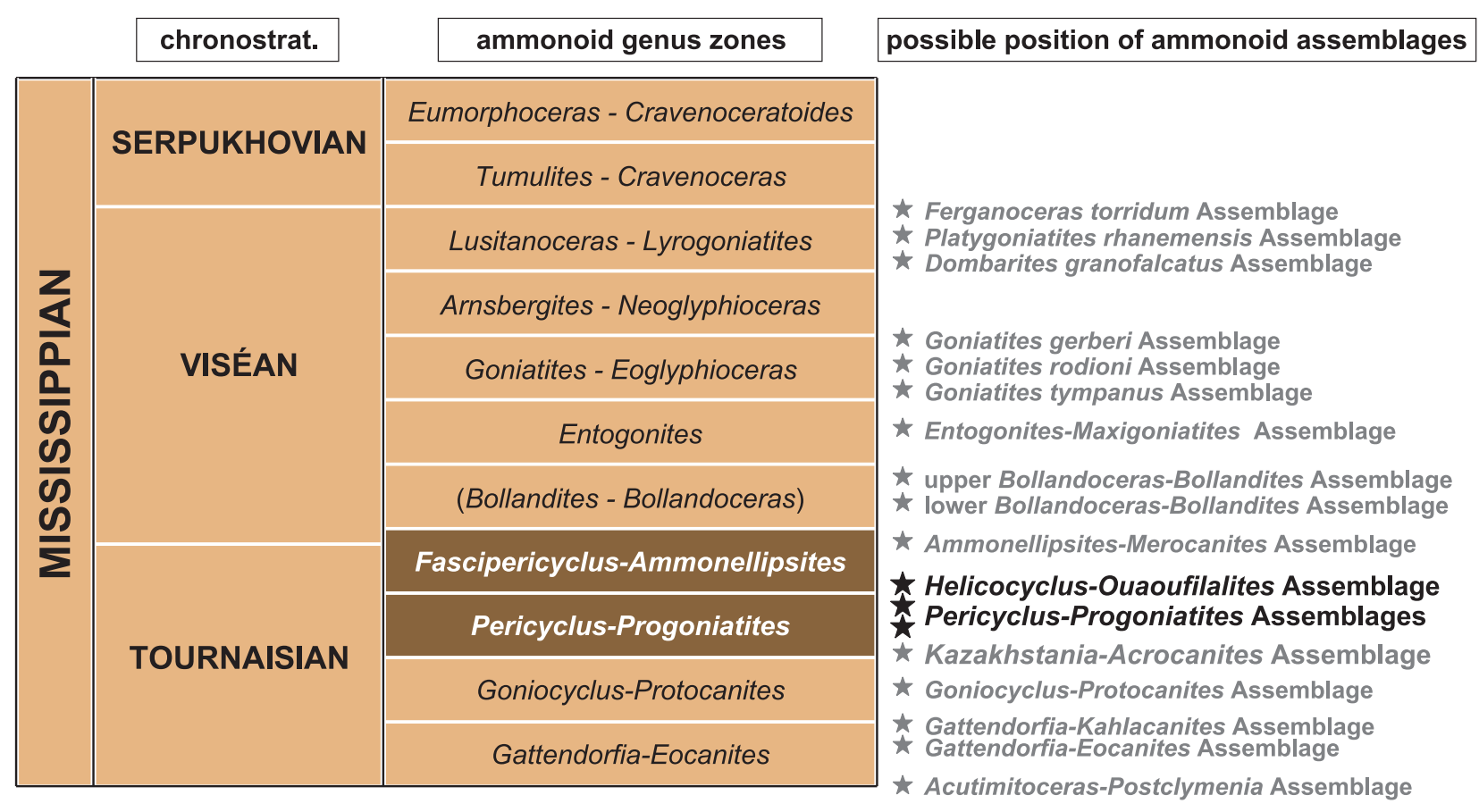

Figure 2. Stratigraphic scheme of the Early Carboniferous (Mississippian) chronostratigraphy and ammonoid zonation with correlation to the North African ammonoid assemblages (after Korn et al. 2004, 2007). Highlighted the position of the assemblages from the Argiles de Teguentour. 


\section{Systematic Palaeontology}

The descriptive part of this monograph will mainly focus on the illustration and morphometric analysis of the spe- cies, with particular attention to their ontogenetic development. The key for the description of the species, including explanation of methods, is published by Korn (2010). Sutural terminology follows Korn et al. (2003b).

Order Goniatitida Hyatt, 1884

Suborder Tornoceratina Wedekind, 1914

Superfamily Prionocerataceae Hyatt, 1884

Family Prionoceratidae Hyatt, 1884

Subfamily Imitoceratinae Ruzhencev, 1950

\section{Imitoceras Schindewolf, 1923}

For a detailed discussion of the genus, see Korn et al. (2010a).

\section{Imitoceras dimidium $\mathbf{n}$. sp.}

Figures 3, 4

Derivation of name. From Latin dimidium $=$ the half, because of the short external lobe.

Holotype. Specimen MB.C.18821.1, illustrated in Figure 3E.

Type locality and horizon. Oued Temertasset, locality and sample MOU-C4 (Mouydir, South Algeria); upper Pericyclus-Progoniatites Assemblage. Material. 383 specimens, conch diameter up to $48 \mathrm{~mm}$.

Diagnosis. Imitoceras with thickly pachyconic or thinly globular conch in the early juvenile stage, conch width index continuously reduced during ontogeny and thinly discoidal in the adult stage; early growth stage subinvolute, closure of the umbilicus at $5 \mathrm{~mm}$ dm; aperture low or moderately high in juveniles and high or very high in adults; umbilicus funnel-shaped with oblique umbilical margin, flanks converging towards the narrowly rounded venter. Internal mould without constrictions. Suture line with small, slightly pouched external lobe; ventrolateral saddle strongly asymmetric, ventrally inclined; adventive lobe strongly asymmetric with slightly convex ventral side and concave dorsal side.

Table 1. Conch ontogeny (Figs 4A-F, K-M) of Imitoceras dimidium n. sp.

\begin{tabular}{|c|c|c|c|}
\hline $\mathrm{dm}$ & conch shape & whorl cross section shape & aperture \\
\hline $2 \mathrm{~mm}$ & $\begin{array}{l}\text { thickly pachyconic to thinly globular; subinvolute } \\
\text { (ww/dm }=0.75-0.95 ; \mathrm{uw} / \mathrm{dm}=0.15-0.25 \text { ) }\end{array}$ & $\begin{array}{l}\text { moderately to strongly depressed; very strongly } \\
\text { embracing (ww/wh } 1.50-2.10 ; \mathrm{IZR}=0.45-0.55 \text { ) }\end{array}$ & $\begin{array}{l}\text { low to moderate } \\
(\text { WER }=1.60-1.90)\end{array}$ \\
\hline $8 \mathrm{~mm}$ & $\begin{array}{l}\text { thickly discoidal to thinly pachyconic; involute } \\
\text { (ww/dm }=0.55-0.64 ; \mathrm{uw} / \mathrm{dm}=0.00-0.05 \text { ) }\end{array}$ & $\begin{array}{l}\text { weakly compressed to weakly depressed; very } \\
\text { strongly embracing } \\
\text { (ww/wh }=0.95-1.15 ; \text { IZR }=0.45-0.55 \text { ) }\end{array}$ & $\begin{array}{l}\text { moderate to high } \\
(\text { WER }=1.85-2.25)\end{array}$ \\
\hline $20 \mathrm{~mm}$ & $\begin{array}{l}\text { thinly to thickly discoidal; involute } \\
\text { (ww/dm }=0.43-0.52 ; \mathrm{uw} / \mathrm{dm}=0.00-0.05 \text { ) }\end{array}$ & $\begin{array}{l}\text { weakly compressed; strongly embracing } \\
(\mathrm{ww} / \mathrm{wh}=0.75-0.95 ; \mathrm{IZR}=0.35-0.45)\end{array}$ & $\begin{array}{l}\text { high to very high } \\
\text { (WER }=2.10-2.35)\end{array}$ \\
\hline $30 \mathrm{~mm}$ & $\begin{array}{l}\text { thinly discoidal; involute } \\
(\mathrm{ww} / \mathrm{dm}=0.40-0.45 ; \mathrm{uw} / \mathrm{dm}=0.00-0.05)\end{array}$ & $\begin{array}{l}\text { weakly compressed; strongly embracing } \\
\text { (ww/wh }=0.70-0.80 ; \text { IZR }=0.35-0.45 \text { ) }\end{array}$ & $\begin{array}{l}\text { high to very high } \\
\text { (WER }=2.20-2.35)\end{array}$ \\
\hline $48 \mathrm{~mm}$ & $\begin{array}{l}\text { thinly discoidal; involute } \\
\text { (ww/dm } \sim 0.42 ; \text { uw/dm }=0.00 \text { ) }\end{array}$ & $\begin{array}{l}\text { weakly compressed; strongly embracing } \\
\text { (ww/wh } \sim 0.70 ; \text { IZR } \sim 0.40 \text { ) }\end{array}$ & $\begin{array}{l}\text { very high } \\
(\text { WER } \sim 2.45)\end{array}$ \\
\hline
\end{tabular}

Table 2. Conch dimensions (in $\mathrm{mm}$ ) and proportions for reference specimens of Imitoceras dimidium $\mathrm{n}$. sp.

\begin{tabular}{|c|c|c|c|c|c|c|c|c|c|c|}
\hline & $\mathrm{dm}$ & wW & wh & uw & ah & $w w / d m$ & ww/wh & $\mathrm{uw} / \mathrm{dm}$ & WER & IZR \\
\hline holotype MB.C.18821.1 & 35.5 & 14.9 & 20.1 & 0.9 & 12.3 & 0.42 & 0.74 & 0.03 & 2.33 & 0.39 \\
\hline paratype MB.C.18779.1 & 31.8 & 13.6 & 17.8 & 1.1 & 10.9 & 0.43 & 0.76 & 0.04 & 2.31 & 0.39 \\
\hline paratype MB.C.19053.2 & 28.2 & 12.6 & 16.4 & 0.5 & 9.8 & 0.45 & 0.77 & 0.02 & 2.35 & 0.40 \\
\hline paratype MB.C.18859.3 & 27.8 & 13.1 & 15.7 & 0.4 & 9.4 & 0.47 & 0.83 & 0.01 & 2.28 & 0.40 \\
\hline paratype MB.C.19053.3 & 23.8 & 11.6 & 13.6 & 0.8 & 8.0 & 0.49 & 0.85 & 0.03 & 2.28 & 0.41 \\
\hline paratype MB.C.19053.1 & 16.6 & 8.3 & 9.2 & 0.5 & 5.6 & 0.50 & 0.90 & 0.03 & 2.28 & 0.39 \\
\hline paratype MB.C.18859.2 & 13.3 & 7.3 & 7.2 & 0.3 & 4.1 & 0.55 & 1.02 & 0.02 & 2.09 & 0.43 \\
\hline paratype MB.C.18859.1 & 11.5 & 6.5 & 6.3 & 0.4 & 3.6 & 0.57 & 1.04 & 0.03 & 2.12 & 0.43 \\
\hline
\end{tabular}



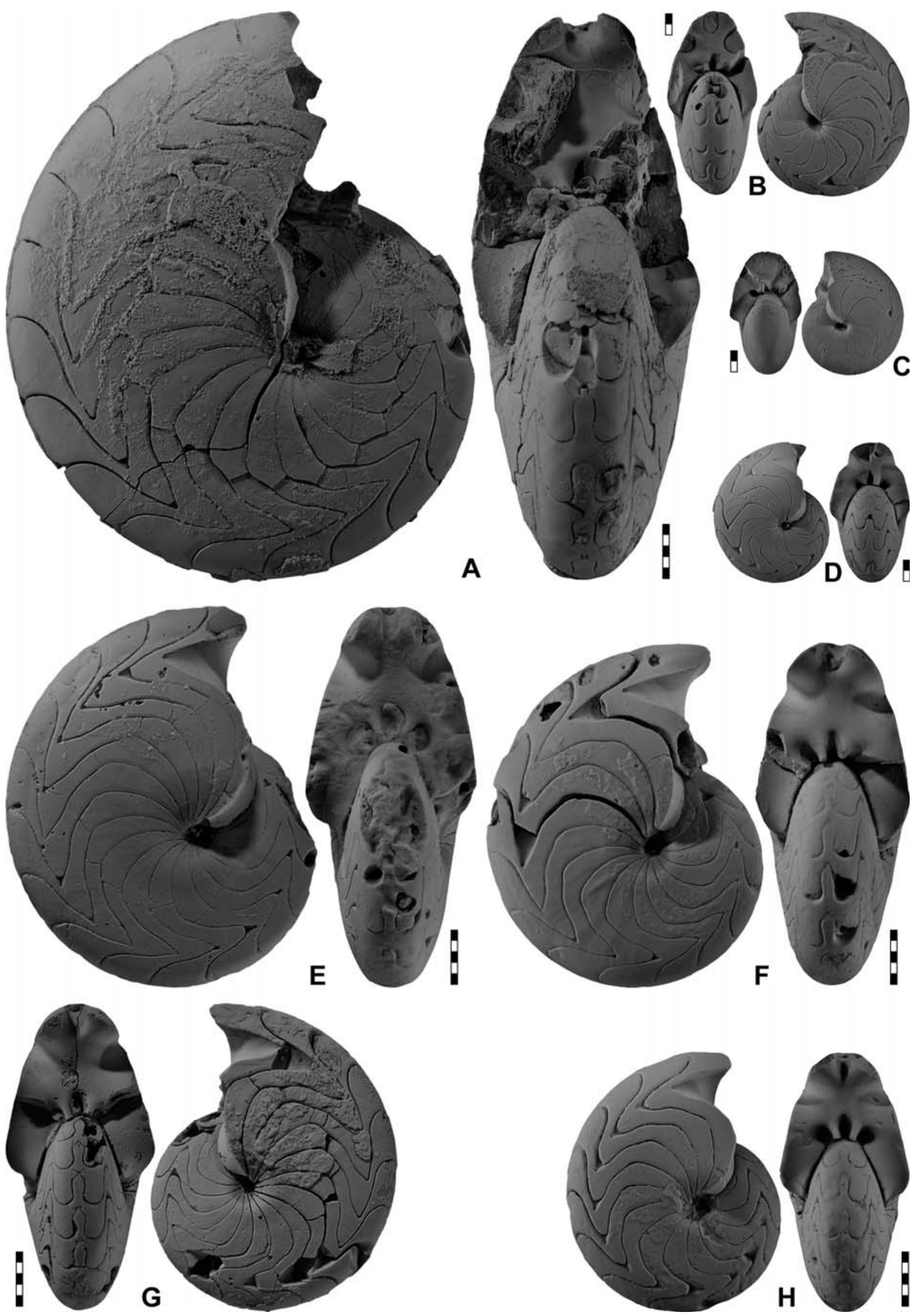

Figure 3. Imitoceras dimidium n. sp.; all $\times 2$. A. Paratype MB.C.18779.1 from locality MOU-B0. B. Paratype MB.C.18859.1 from locality MOU-D1. C. Paratype MB.C.18859.2 from locality MOU-D1. D. Paratype MB.C.19053.1 from locality MOU-Z. E. Holotype MB.C.18821.1 from locality MOU-C4. F. Paratype MB.C.19053.2 from locality MOU-Z. G. Paratype MB.C.18859.3 from locality MOU-D1. H. Paratype MB.C.19053.3 from locality MOU-Z. 
Table 3. Suture line proportions (Figs $4 \mathrm{G}-\mathrm{J}$ ) for Imitoceras dimidium $\mathrm{n}$. sp.

\begin{tabular}{lllllllll}
\hline specimen & at dm & EL w/d & EL/VLS & EL/AL & MS h & VLS w/h & remarks \\
\hline holotype MB.C.18821.1 & $33.8 \mathrm{~mm}$ & 0.32 & 0.46 & 0.55 & 0.00 & 0.70 & E lobe very short \\
paratype MB.C.19053.2 & $23.0 \mathrm{~mm}$ & 0.34 & 0.45 & 0.66 & 0.00 & 0.75 & E lobe comparatively narrow \\
paratype MB.C.18859.1 & $15.5 \mathrm{~mm}$ & 0.29 & 0.46 & 0.67 & 0.00 & 0.63 & 0.67 & A lobe comparatively wide \\
paratype MB.C.19053.1 & $12.4 \mathrm{~mm}$ & 0.38 & 0.57 & 0.56 & 0.00 & & \\
\hline
\end{tabular}
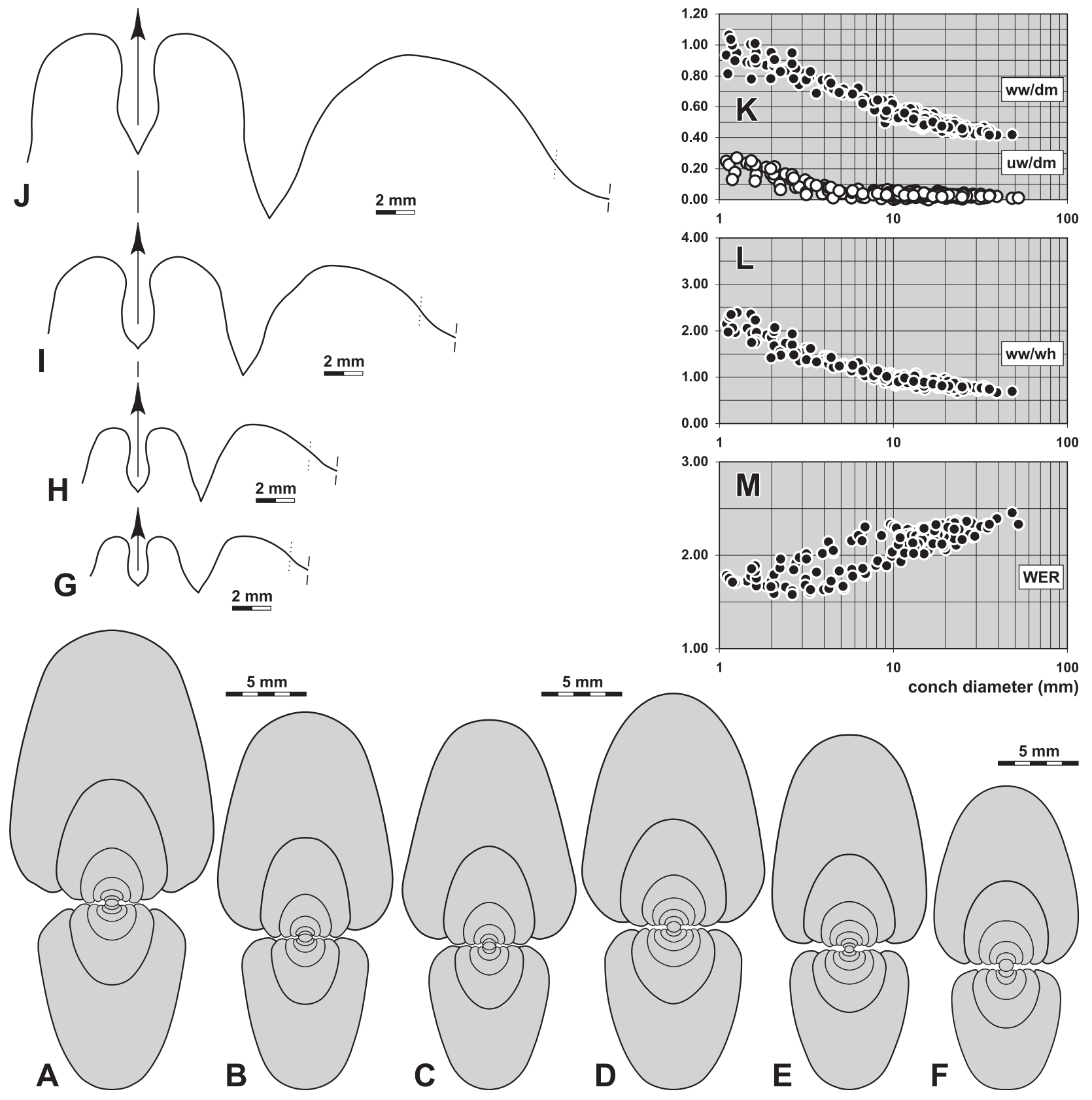

Figure 4. Imitoceras dimidium n. sp. A. Cross section of paratype MB.C.18884.1 from locality MOU-D2; × 2.5. B. Cross section of paratype MB.C.18943.1 from locality MOU-E07; $\times 2.5$. C. Cross section of paratype MB.C.18859.4 from locality MOU-D1; $\times 2.5$. D. Cross section of paratype MB.C.19053.4 from locality MOU-Z; $\times 2.5$. E. Cross section of paratype MB.C.18859.5 from locality MOU-D1; $\times 2.5$. F. Cross section of paratype MB.C.18884.2 from locality MOU-D2; $\times 2.5$. G. Suture line of paratype MB.C.19053.1 from locality MOU-Z, at $12.4 \mathrm{~mm} \mathrm{dm}, 7.4 \mathrm{~mm}$ ww, $7.6 \mathrm{~mm}$ wh; ×3.0. H. Suture line of paratype MB.C.18859.1 from locality MOU-D1, at $15.5 \mathrm{~mm} \mathrm{dm}, 8.1 \mathrm{~mm}$ ww, $9.5 \mathrm{~mm}$ wh; $\times 3.0$. I. Suture line of paratype MB.C.19053.2 from locality MOU-Z, at $23.0 \mathrm{~mm} \mathrm{dm}, 11.5 \mathrm{~mm}$ ww, $14.2 \mathrm{~mm}$ wh; $\times 3.0$. J. Suture line of holotype MB.C.18821.1 from locality MOU-C4, at $33.8 \mathrm{~mm} \mathrm{dm}, 15.1 \mathrm{~mm}$ ww, $20.7 \mathrm{~mm}$ wh; $\times 3.0$. K-M. Ontogenetic development of the conch width index (ww/dm), umbilical width index (uw/dm), whorl width index (ww/wh), and whorl expansion rate (WER) of all available specimens. 
Discussion. Imitoceras dimidium differs from I. altilobatum Korn, Ebbighausen \& Bockwinkel, 2010 from the area of Timimoun in the shallower external lobe, the more asymmetric adventive lobe, and in the umbilicus, which in I. altilobatum is not funnel-shaped as in I. dimidium. I. dimidium has, in comparable growth stages, a more slender conch than I. altilobatum ( $\mathrm{ww} / \mathrm{dm}=0.60$ in I. altilobatum but 0.50 in I. dimidium and I. strictum at $15 \mathrm{~mm} \mathrm{dm}$ ). I. strictum possesses steinkern constrictions and is thus clearly separated from I. dimidium.

I. dimidium differs from I. ixion (Hall, 1860) and I. rotatorium (de Koninck, 1844) in the less asymmetric adventive lobe, but particularly in the funnel-shaped umbilicus (I. ixion and I. rotatorium possess a broadly rounded umbilical margin).

\section{Imitoceras strictum n. sp.}

Figures 5, 6

Derivation of name. From Latin strictum $=$ constricted, because of the steinkern constrictions.

Holotype. Specimen MB.C.18885.1, illustrated in Figure 5A.

Type locality and horizon. Oued Temertasset, locality and sample MOU-D2 (Mouydir, South Algeria); upper Pericyclus-Progoniatites Assemblage.

Material. 70 specimens, conch diameter up to $20 \mathrm{~mm}$.

Diagnosis. Imitoceras with thickly pachyconic or thinly globular conch in the early juvenile stage, conch width index continuously reduced during ontogeny and thinly discoidal in the adult stage; early growth stage subinvolute, closure of the umbilicus at $3 \mathrm{~mm}$ dm; aperture low in juveniles and high in adults; umbilicus funnel-shaped with oblique umbilical margin, flanks converging towards the narrowly rounded venter. Internal mould with gently biconvex constrictions. Suture line with small, slightly pouched external lobe; ventrolateral saddle strongly asymmetric, ventrally inclined; adventive lobe slightly asymmetric with slightly convex ventral side and concave dorsal side.

Table 4. Conch ontogeny (Figs 6A, B, F-H) of Imitoceras strictum n. sp.

\begin{tabular}{|c|c|c|c|}
\hline$d m$ & conch shape & whorl cross section shape & aperture \\
\hline $2 \mathrm{~mm}$ & $\begin{array}{l}\text { thickly pachyconic; subinvolute } \\
\text { (ww/dm } \sim 0.82 ; u w / d m=0.18-0.23 \text { ) }\end{array}$ & $\begin{array}{l}\text { moderately depressed; very strongly embracing } \\
\text { (ww/wh 1.90; IZR } \sim 0.52 \text { ) }\end{array}$ & $\begin{array}{l}\text { low } \\
(\text { WER } \sim 1.60)\end{array}$ \\
\hline $8 \mathrm{~mm}$ & $\begin{array}{l}\text { thickly discoidal to thinly pachyconic; involute } \\
\text { (ww/dm }=0.55-0.65 ; \mathrm{uw} / \mathrm{dm}=0.00-0.05 \text { ) }\end{array}$ & $\begin{array}{l}\text { weakly compressed to weakly depressed; very } \\
\text { strongly embracing } \\
\text { (ww/wh }=0.90-1.10 ; \text { IZR }=0.45-0.55 \text { ) }\end{array}$ & $\begin{array}{l}\text { moderate to high } \\
(\mathrm{WER}=1.80-2.10)\end{array}$ \\
\hline $20 \mathrm{~mm}$ & $\begin{array}{l}\text { thinly to thickly discoidal; involute } \\
\text { (ww/dm }=0.42-0.50 ; \mathrm{uw} / \mathrm{dm}=0.00-0.05 \text { ) }\end{array}$ & $\begin{array}{l}\text { weakly compressed; strongly embracing } \\
\text { (ww/wh } \sim 0.80 ; \text { IZR } \sim 0.44 \text { ) }\end{array}$ & $\begin{array}{l}\text { high } \\
\text { (WER } \sim 2.20)\end{array}$ \\
\hline
\end{tabular}

Table 5. Conch dimensions (in $\mathrm{mm}$ ) and proportions for reference specimens of Imitoceras strictum $\mathrm{n}$. $\mathrm{sp}$.

\begin{tabular}{|c|c|c|c|c|c|c|c|c|c|c|}
\hline & $\mathrm{dm}$ & ww & wh & uw & ah & $w w / d m$ & ww/wh & $\mathrm{uw} / \mathrm{dm}$ & WER & IZR \\
\hline holotype MB.C.18885.1 & 17.8 & 9.4 & 9.7 & 0.5 & 5.5 & 0.53 & 0.97 & 0.03 & 2.08 & 0.44 \\
\hline paratype MB.C.18885.2 & 16.9 & 7.8 & 9.9 & 0.5 & 5.2 & 0.46 & 0.78 & 0.03 & 2.11 & 0.47 \\
\hline paratype MB.C.18885.3 & 9.8 & 5.6 & 5.7 & 0.3 & 3.0 & 0.57 & 0.98 & 0.03 & 2.10 & 0.47 \\
\hline
\end{tabular}

Table 6. Suture line proportions (Figs 6C-E) for Imitoceras strictum n. sp.

\begin{tabular}{llllllll}
\hline specimen & at dm & EL w/d & EL/VLS & EL/AL & MS h & VLS w/h \\
\hline holotype MB.C.18885.1 & $17.4 \mathrm{~mm}$ & 0.43 & 0.62 & 0.81 & 0.00 & 0.69 \\
paratype MB.C.18885.2 & $16.4 \mathrm{~mm}$ & 0.46 & 0.62 & 0.73 & 0.00 & 0.73 & 0.68 \\
paratype MB.C.18885.3 & $9.7 \mathrm{~mm}$ & 0.29 & 0.43 & 0.61 & 0.00 & E lobe very narrow \\
\hline
\end{tabular}

Discussion. Imitoceras strictum differs from the co-occurring I. dimidium in the steinkern constrictions. The same character distinguishes the new species from most of the other members of the genus. I. abundans Miller \& Collinson, 1951 possesses constrictions, but these are almost linear in their course, in contrast to the biconvex constrictions of I. strictum. 

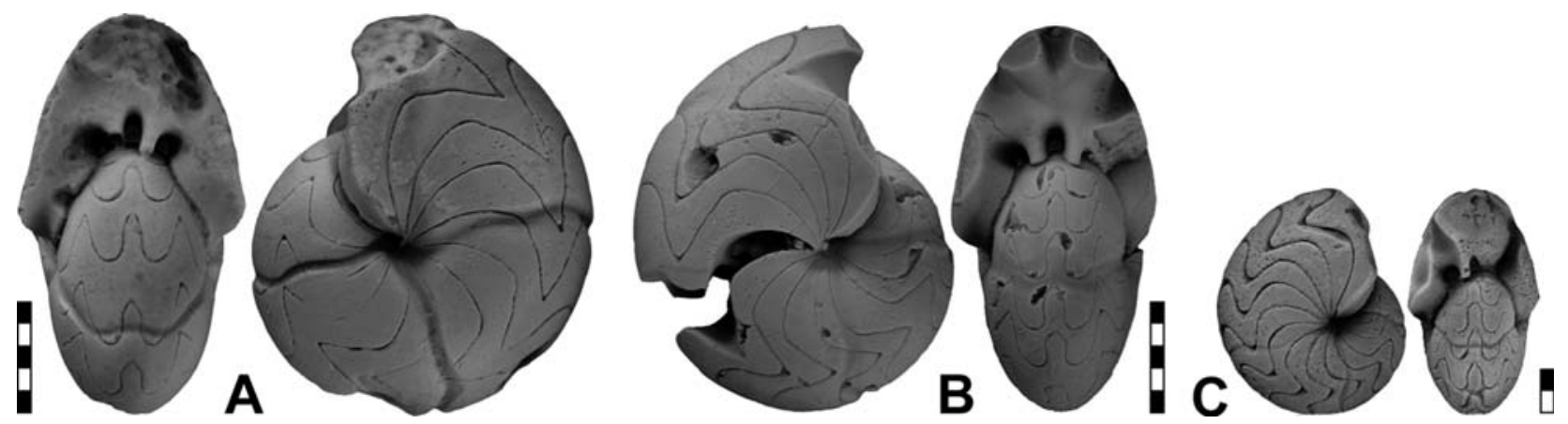

Figure 5. Imitoceras strictum n. sp. from locality MOU-D2; all $\times 2$. A. Holotype MB.C.18885.1. B. Paratype MB.C.18885.2. C. Paratype MB.C.18885.3.
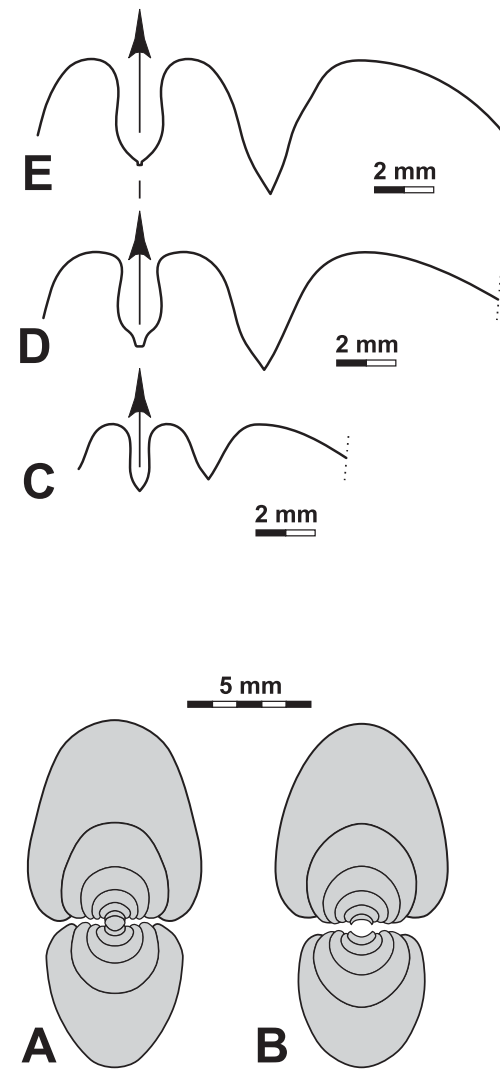
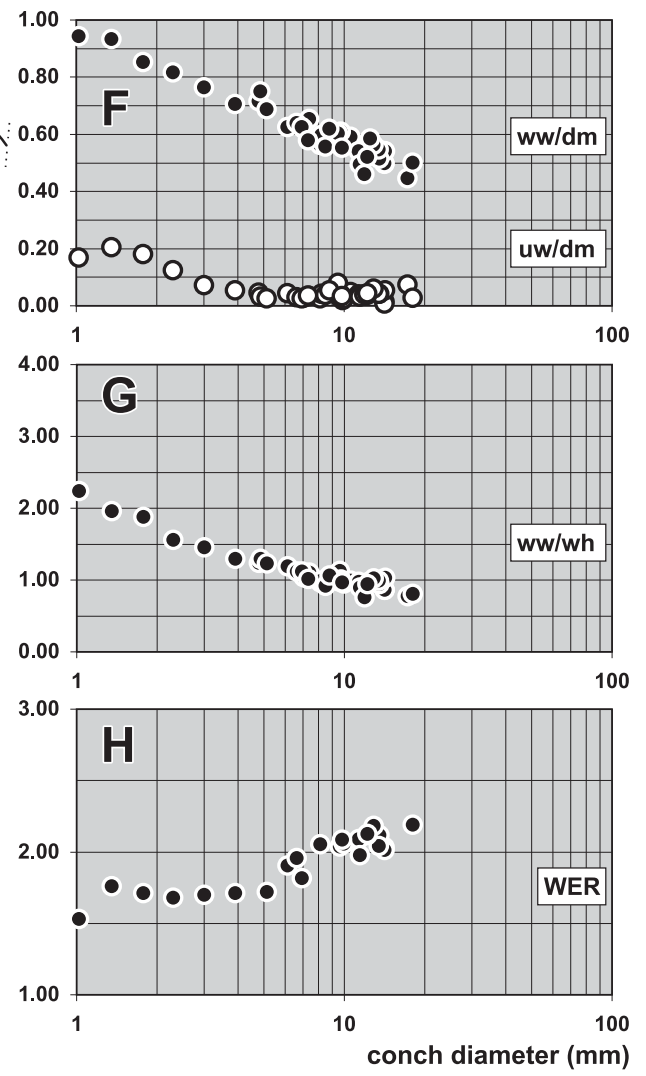

Figure 6. Imitoceras strictum n. sp. A. Cross section of paratype MB.C.18720.1 from locality A264; $\times 2.5$. B. Cross section of paratype 3488 from locality MOU-D2; $\times 2.5$. C. Suture line of paratype MB.C.18885.3 from locality MOU$\mathrm{D} 2$, at $9.7 \mathrm{~mm} \mathrm{dm}, 5.1 \mathrm{~mm} \mathrm{ww}$, $5.9 \mathrm{~mm}$ wh; $\times 3.0$. D. Suture line of paratype MB.C.18885.2 from locality MOU-D2, at $16.4 \mathrm{~mm} \mathrm{dm}, 8.1 \mathrm{~mm}$ ww, $10.4 \mathrm{~mm}$ wh; $\times 3.0$. E. Suture line of holotype MB.C.18885.1 from locality MOU-D2, at $17.4 \mathrm{~mm} \mathrm{dm}$, $9.3 \mathrm{~mm}$ ww, $10.5 \mathrm{~mm}$ wh; $\times 3.0$. FH. Ontogenetic development of the conch width index (ww/dm), umbilical width index (uw/dm), whorl width index (ww/wh), and whorl expansion rate (WER) of all available specimens.

\section{Triimitoceras Korn, Bockwinkel, Ebbighausen \& Klug, 2003}

For a detailed discussion of the genus, see Korn et al. (2010a).

\section{Triimitoceras tantulum n. sp.}

Figures 7,8

Derivation of name. From Latin tantulum $=$ small, because of the small size.

Holotype. Specimen MB.C.18721, illustrated in Figure 7A.

Type locality and horizon. Oued Temertasset, locality and sample A264 (Mouydir, South Algeria); upper Pericyclus-Progoniatites Assemblage. Material. Five specimens, conch diameter up to $19 \mathrm{~mm}$.

Diagnosis. Triimitoceras with thickly pachyconic conch in the early juvenile stage, conch width index continuously reduced during ontogeny and being thinly discoidal at $18 \mathrm{~mm} \mathrm{dm}$; aperture very low or low. Internal mould with concavo-convex constrictions with small ventral sinus. Suture line with lanceolate, deep external lobe; ventrolateral saddle slightly asymmetric; adventive lobe V-shaped, almost symmetric. 
Table 7. Conch shape (Figs 8A, C-E) of Triimitoceras tantulum n. sp.

\begin{tabular}{lllll}
\hline $\mathrm{dm}$ & conch shape & whorl cross section shape & aperture \\
\hline $4 \mathrm{~mm}$ & thickly pachyconic; involute & moderately depressed; very strongly embracing & very low \\
& $($ ww/dm $\sim 0.80 ;$ uw/dm $\sim 0.06)$ & $($ ww/wh $\sim 1.55 ;$ IZR $\sim 0.60)$ & $($ WER $\sim 1.48)$ & low \\
$10 \mathrm{~mm}$ & thickly discoidal; involute & weakly depressed; very strongly embracing & (WER $\sim 1.55)$ \\
& $($ ww/dm $\sim 0.58 ;$ uw/dm $\sim 0.06)$ & (ww/wh $\sim 1.10 ;$ IZR $\sim 0.60)$ & low \\
$18 \mathrm{~mm}$ & thickly discoidal; involute & $($ ww/wh $\sim 0.90 ;$ IZR $\sim 0.58)$ & (WER $\sim 1.65)$
\end{tabular}

Table 8. Conch dimensions (in $\mathrm{mm}$ ) and proportions for reference specimens of Triimitoceras tantulum $\mathrm{n}$. sp.

\begin{tabular}{|c|c|c|c|c|c|c|c|c|c|c|}
\hline & $\mathrm{dm}$ & ww & wh & uw & ah & ww/dm & ww/wh & uw/dm & WER & IZR \\
\hline paratype MB.C.19024.2 & 18.3 & 8.7 & 9.6 & 1.1 & 4.2 & 0.48 & 0.91 & 0.06 & 1.68 & 0.57 \\
\hline holotype MB.C.18721 & 10.2 & 6.1 & 5.4 & 0.7 & 2.1 & 0.60 & 1.13 & 0.06 & 1.58 & 0.61 \\
\hline paratype MB.C.19024.1 & 8.2 & 5.2 & 4.6 & 0.4 & - & 0.63 & 1.12 & 0.05 & - & - \\
\hline
\end{tabular}

Table 9. Suture line proportions (Fig. 8B) for Triimitoceras tantulum n. sp.

\begin{tabular}{llllllll}
\hline specimen & at dm & EL w/d & EL/VLS & EL/AL & MS h & VLS w/h & remarks \\
\hline holotype MB.C.18721 & $9.2 \mathrm{~mm}$ & 0.37 & 0.65 & 0.48 & 0.00 & 0.57 & E lobe as deep as A lobe \\
\hline
\end{tabular}

Discussion. Triimitoceras tantulum differs from the type species T. epiwocklumeriforme Korn, Bockwinkel, Ebbighausen \& Klug, 2003 in the lanceolate external lobe (which is pouched in the adult stage of T. epiwocklumeriforme). T. tantulum differs from T. amplisellatum Korn, Ebbighausen \& Bockwinkel, 2010 mainly in the less strongly tripartite inner whorls and in the lower aperture in comparable growth stages (at $15 \mathrm{~mm} \mathrm{dm}$ : WER $=1.60$ in T. tantulum but 1.95 in T. amplisellatum).
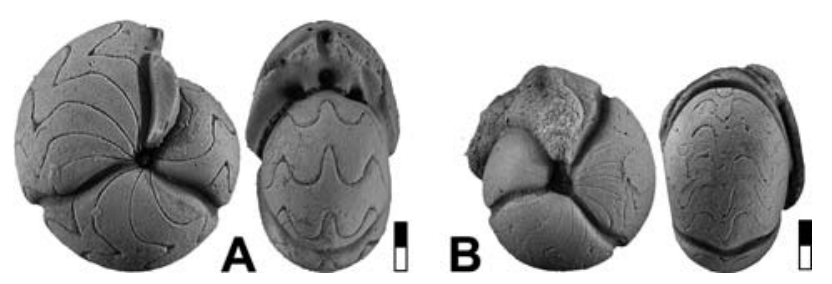

Figure 7. Triimitoceras tantulum n. $\mathrm{sp}$.; all $\times 2.5$. A. Holotype MB.C.18721 from locality A-264. B. Paratype MB.C.19024.1 from locality MOU-V.
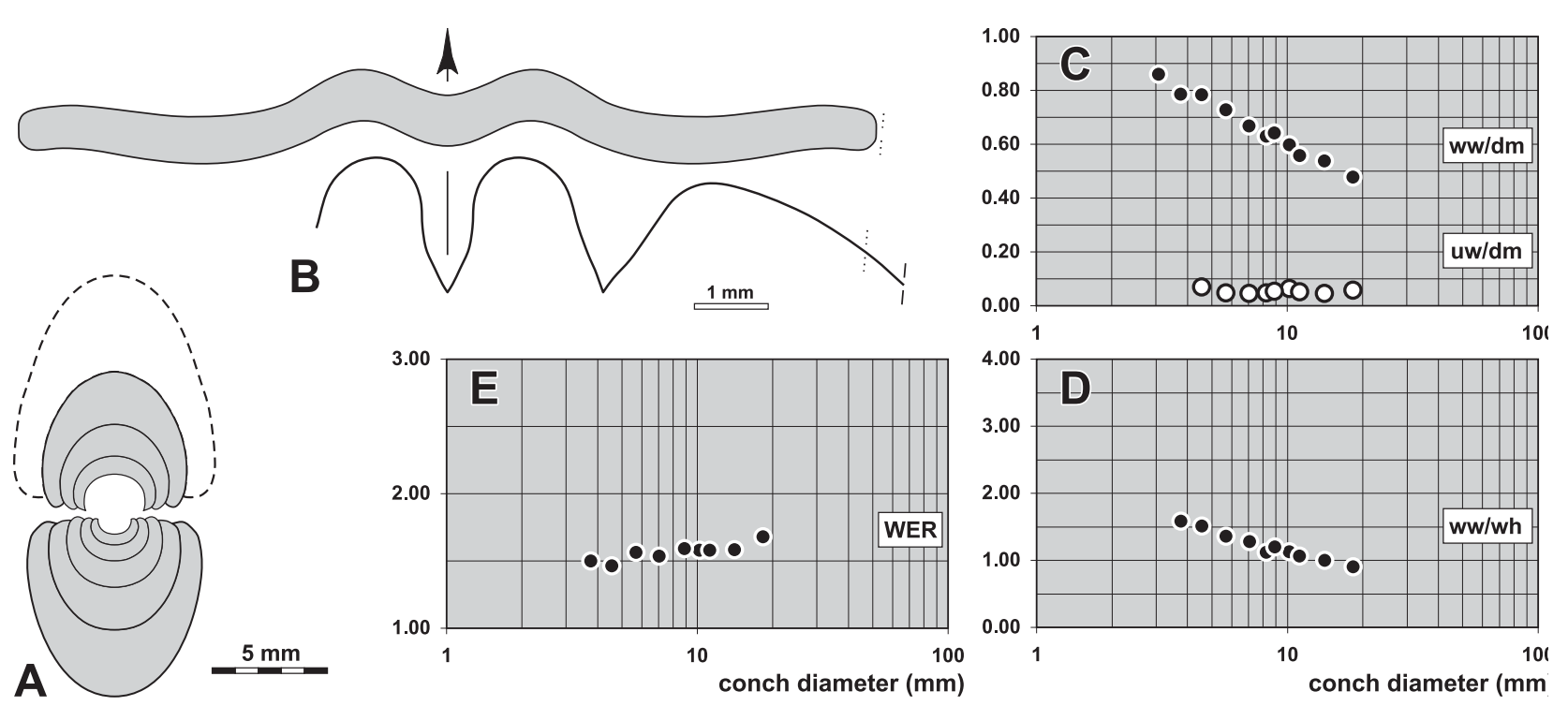

Figure 8. Triimitoceras tantulum n. sp. A. Cross section of paratype MB.C.19024.2 from locality MOU-V; $\times 2.5$. B. Suture line and constriction of holotype MB.C.18721 from locality A-264, at $9.2 \mathrm{~mm} \mathrm{dm}, 5.8 \mathrm{~mm}$ ww, $4.6 \mathrm{~mm}$ wh; $\times 8.0$. C-E. Ontogenetic development of the conch width index (ww/dm), umbilical width index (uw/dm), whorl width index (ww/wh), and whorl expansion rate (WER) of all available specimens. 
Family Acrocanitidae Korn, Bockwinkel \& Ebbighausen, 2007

Family definition. Prionocerataceae with lenticular, evolute to almost involute conch form. Suture line multilobate with increasing number of lateral lobes.

Included genera.

Acrocanites Schindewolf, 1922

Jdaidites Korn, Bockwinkel \& Ebbighausen, 2007

\section{Acrocanites Schindewolf, 1922}

For a detailed discussion of the genus, see Korn et al. (2007, 2010a).

\section{Acrocanites disparilis n. sp.}

Figures 9, 10

Derivation of name. From Latin disparilis = unequal, because of the size of the lobes on the flank.

Holotype. Specimen MB.C.18855, illustrated in Figure 9A.

Type locality and horizon. Oued Temertasset, locality and sample MOU-D0 (Mouydir, South Algeria); lower part of the Pericyclus-Progoniatites Assemblage.

Material. 63 specimens, conch diameter up to $22 \mathrm{~mm}$.

Diagnosis. Acrocanites with thinly pachyconic conch in the earliest juvenile stage (1 $\mathrm{mm} \mathrm{dm})$, becoming rapidly slender during ontogeny and being extremely discoidal at $20 \mathrm{~mm} \mathrm{dm}$; conch evolute in all stages with a slight reduction of the umbilical width in the adult stage; venter broadly rounded in juveniles and narrowly rounded in adults; aperture low or very low. Steinkern smooth except for a very shallow radial folding on the flanks. Suture line in the adult stage with lanceolate external lobe; five pouched and acute lobes on the flank, saddles between these lobes strongly inflated; two or three small, V-shaped and acute lobes on the umbilical wall.

Table 10. Conch ontogeny (Figs 10A, B, G-I) of Acrocanites disparilis n. sp.

\begin{tabular}{|c|c|c|c|}
\hline$d m$ & conch shape & whorl cross section shape & aperture \\
\hline $2 \mathrm{~mm}$ & $\begin{array}{l}\text { thinly discoidal; evolute } \\
\text { (ww/dm } \sim 0.40 ; \text { uw/dm } \sim 0.55 \text { ) }\end{array}$ & $\begin{array}{l}\text { moderately depressed; weakly embracing } \\
\text { (ww/wh } \sim 1.60 ; \text { IZR } \sim 0.10 \text { ) }\end{array}$ & $\begin{array}{l}\text { low } \\
\text { (WER } \sim 1.65)\end{array}$ \\
\hline $8 \mathrm{~mm}$ & $\begin{array}{l}\text { extremely discoidal; evolute } \\
\text { (ww/dm } \sim 0.28 ; \mathrm{uw} / \mathrm{dm}=0.55-0.60 \text { ) }\end{array}$ & $\begin{array}{l}\text { weakly depressed; moderately embracing } \\
(\mathrm{ww} / \mathrm{wh}=1.10-1.25 ; \mathrm{IZR}=0.15-0.20)\end{array}$ & $\begin{array}{l}\text { very low } \\
(\text { WER }=1.45-1.50)\end{array}$ \\
\hline $20 \mathrm{~mm}$ & $\begin{array}{l}\text { extremely discoidal; evolute } \\
(\mathrm{ww} / \mathrm{dm} \sim 0.22 ; \mathrm{uw} / \mathrm{dm}=0.48-0.52 \text { ) }\end{array}$ & $\begin{array}{l}\text { weakly compressed; strongly embracing } \\
\text { (ww/wh } \sim 0.70 ; \text { IZR } \sim 0.32 \text { ) }\end{array}$ & $\begin{array}{l}\text { low } \\
(\text { WER } \sim 1.65)\end{array}$ \\
\hline
\end{tabular}

Table 11. Conch dimensions (in mm) and proportions for reference specimens of Acrocanites disparilis n. sp.

\begin{tabular}{|c|c|c|c|c|c|c|c|c|c|c|}
\hline & $\mathrm{dm}$ & wW & wh & uw & ah & $w w / d m$ & ww/wh & $\mathrm{uw} / \mathrm{dm}$ & WER & IZR \\
\hline holotype MB.C.18855 & 25.4 & 5.0 & 7.9 & 11.6 & 5.5 & 0.20 & 0.63 & 0.46 & 1.62 & 0.31 \\
\hline paratype MB.C.19025.1 & 22.0 & 4.9 & 7.3 & 10.5 & 5.0 & 0.22 & 0.68 & 0.48 & 1.67 & 0.32 \\
\hline paratype MB.C.19025.2 & 11.1 & 2.6 & 2.9 & 6.3 & 2.3 & 0.23 & 0.91 & 0.57 & 1.57 & 0.21 \\
\hline paratype MB.C.18861.1 & 10.8 & 2.8 & 2.8 & 5.8 & 2.2 & 0.26 & 0.97 & 0.53 & 1.58 & 0.23 \\
\hline
\end{tabular}

Table 12. Suture line characteristics (Figs 10C-F) for Acrocanites disparilis n. sp.

\begin{tabular}{lrrrrl}
\hline specimen & at dm & EL w/d & external lobe & adventive lobe & lateral lobes \\
\hline holotype MB.C.18855 & $25.0 \mathrm{~mm}$ & 0.50 & spatulate & almost symmetric, subacute & 7 , all acute, inner three small \\
dto. & c. $18.0 \mathrm{~mm}$ & 0.46 & spatulate & almost symmetric, subacute & 5 , mostly acute, inner one small \\
paratype MB.C.19025.1 & $21.8 \mathrm{~mm}$ & 0.50 & spatulate & slightly asymmetric, acute & 6 , some acute, inner two small \\
paratype MB.C.19025.2 & $9.8 \mathrm{~mm}$ & 0.35 & spatulate & slightly asymmetric, acute & 3 , outer two rounded \\
\hline
\end{tabular}

Discussion. Acrocanites disparilis differs from A. imperfectus Korn, Ebbighausen \& Bockwinkel, 2010 from Timimoun in the higher number of sutural elements. A. disparilis possesses five large lobes on the flank and two or three small lobes on the umbilical wall, whereas $A$. imperfectus shows only three large lobes on the flank and one or two small lobes on the umbilical wall. The external lobe is subparallel in A. disparilis but pouched in A. imperfectus. 

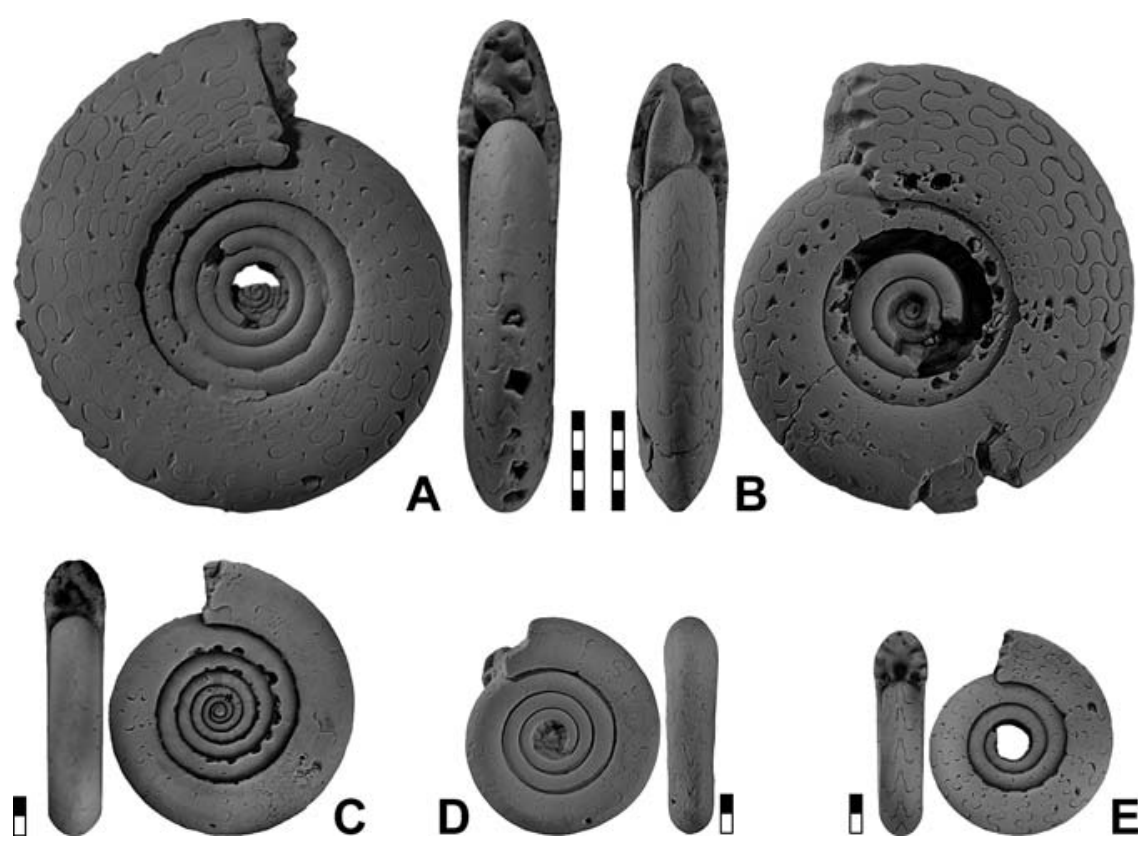

Figure 9. Acrocanites disparilis n. sp.; all $\times 2$. A. Holotype MB.C.18855 from locality MOU-D0. B. Paratype MB.C.19025.1 from locality MOU-V. C. Paratype MB.C.18822 from locality MOU-C4. D. Paratype MB.C.19025.2 from locality MOU-V. E. Paratype MB.C.18861.1 from locality MOU-D1.
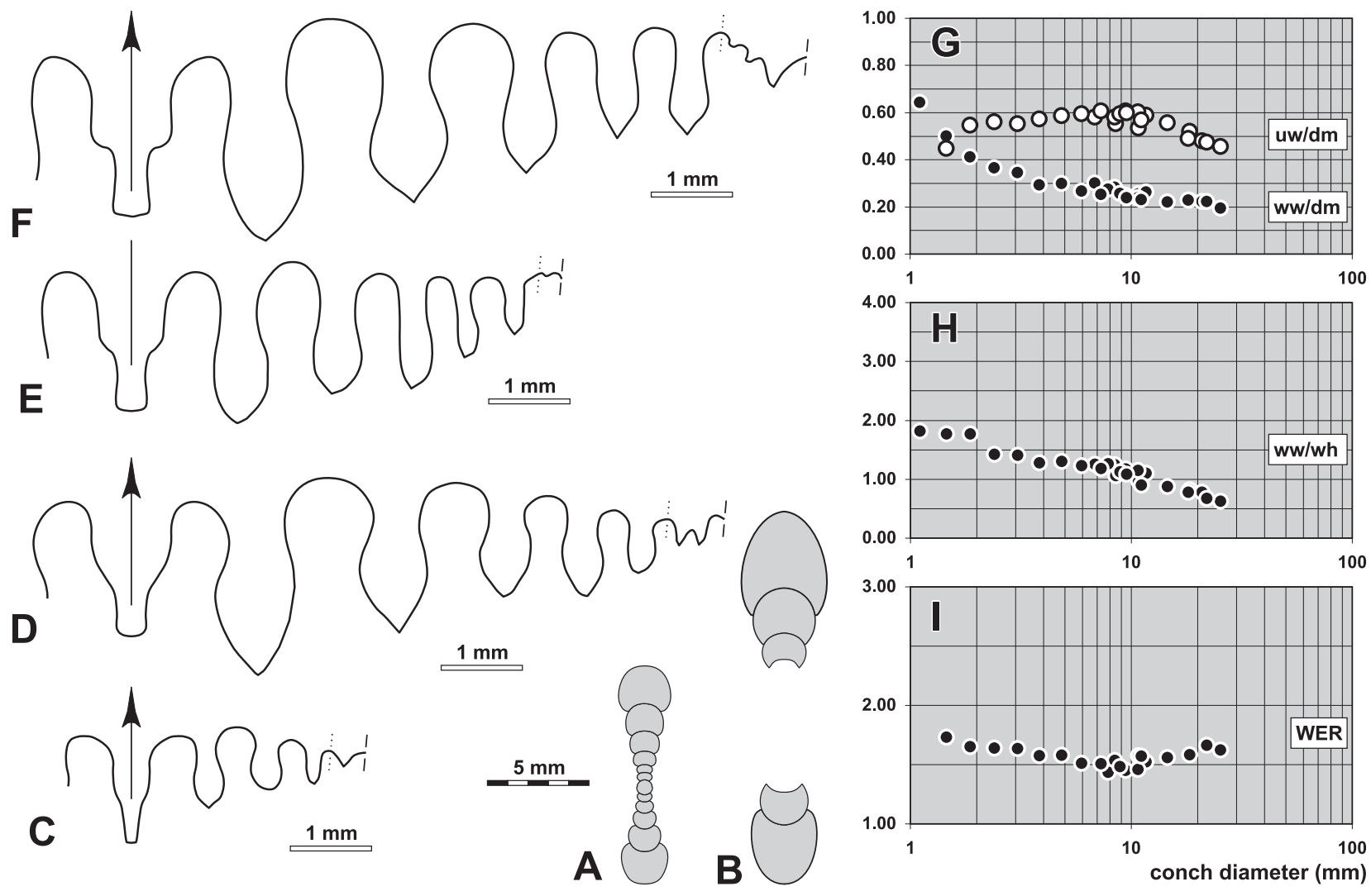

Figure 10. Acrocanites disparilis n. sp. A. Cross section of paratype MB.C.19025.3 from locality MOU-V; $\times 2.5$. B. Cross section of paratype MB.C.19025.4 from locality MOU-V; × 2.5. C. Suture line of paratype MB.C.19025.2 from locality MOU-V, at $9.8 \mathrm{~mm} \mathrm{dm}, 2.6 \mathrm{~mm}$ ww, $2.0 \mathrm{~mm}$ wh; $\times 10.0$. D. Suture line of paratype MB.C.19025.1 from locality MOU-V, at $21.8 \mathrm{~mm} \mathrm{dm}$, $4.5 \mathrm{~mm}$ ww, $6.8 \mathrm{~mm}$ wh; $\times 10.0$. E. Suture line of holotype MB.C. 18855 from locality MOU-D0, at $4.1 \mathrm{~mm} w w, 4.5 \mathrm{~mm}$ wh; $\times$ 10.0. F. Suture line of holotype MB.C.18855 from locality MOU-D0, at $25.0 \mathrm{~mm} \mathrm{dm}, 5.4 \mathrm{~mm}$ ww, $7.4 \mathrm{~mm}$ wh; $\times 10.0$. G-I. Ontogenetic development of the conch width index (ww/dm), umbilical width index (uw/dm), whorl width index (ww/wh), and whorl expansion rate (WER) of all available specimens. 
The two species A. multilobatus Schindwolf, 1926 and A.tornacensis Delépine, 1940 are problematic because they are based on poorly preserved material. Both species have a V-shaped external lobe, in contrast to the external lobe with subparallel flanks in A. disparilis.

\section{Jdaidites Korn, Bockwinkel \& Ebbighausen, 2007}

Type species. Jdaidites serpentinus Korn, Bockwinkel \& Ebbighausen, 2007 (OD).

Genus definition. Acrocanitidae with extremely discoidal, subinvolute or subevolute conch, venter acute. Six or seven lobes on the flank and the umbilical wall.

Included species.

cultellus: Jdaidites cultellus n. sp.; Mouydir, Algeria.

serpentinus: Jdaidites serpentinus Korn, Bockwinkel \& Ebbighausen, 2007, p. 140; Anti-Atlas, Morocco.

Discussion. In the suture line, Jdaidites is most similar to advanced species of the genus Acrocanites, such as A. multilobatus Schindewolf, 1922; the number of lobes and their shapes are nearly identical. The conch shape of the two genera, however, is very different; Acrocanites is rather widely umbilicate and Jdaidites is narrowly umbilicate.

\section{Jdaidites cultellus n. sp.}

Figures 11, 12

Derivation of name. From Latin cultellus $=$ a little knife, because of the conch shape.

Holotype. Specimen MB.C.18823, illustrated in Figure 11.

Type locality and horizon. Oued Temertasset, locality and sample MOU-C4 (Mouydir, South Algeria); upper Pericyclus-Progoniatites Assemblage. Material. Only the holotype with $19 \mathrm{~mm}$ conch diameter and one whorl fragment.

Diagnosis. Jdaidites with extremely discoidal, subevolute conch. Suture line with six lanceolate or V-shaped, subacute or acute lobes on the flank and the umbilical wall.

Table 13. Conch shape (Fig. 12A) of Jdaidites cultellus n. sp.

\begin{tabular}{llll}
\hline $\mathrm{dm}$ & conch shape & whorl cross section shape & aperture \\
\hline $19 \mathrm{~mm}$ & extremely discoidal; subevolute & strongly compressed; moderately embracing & high \\
& $($ ww/dm $\sim 0.16 ;$ uw/dm $\sim 0.38)$ & $($ ww/wh $\sim 0.38 ;$ IZR $\sim 0.28)$ & $($ WER $\sim 2.02)$
\end{tabular}

Table 14. Conch dimensions (in $\mathrm{mm}$ ) and proportions for reference specimens of Jdaidites cultellus $\mathrm{n}$. sp.

\begin{tabular}{llllllllllll}
\hline & $\mathrm{dm}$ & ww & wh & uw & ah & ww/dm & ww/wh & uw/dm & WER & IZR & \\
\hline holotype MB.C.18823 & 19.2 & 3.0 & 7.9 & 7.3 & 5.7 & 0.16 & 0.38 & 0.38 & 2.02 & 0.28 & \\
\hline
\end{tabular}

Table 15. Suture line proportions (Figs 12B, C) for Jdaidites cultellus n. sp.

\begin{tabular}{llllll}
\hline specimen & at dm & EL w/d & external lobe adventive lobe & lateral lobes \\
\hline holotype MB.C.18823 & $18.6 \mathrm{~mm}$ & 0.29 & spatulate & inflated, rounded & 5 , all acute, first pouched \\
dto. & c. $13.0 \mathrm{~mm}$ & 0.21 & spatulate & inflated, rounded & 4 , inner three acute, first rounded \\
\hline
\end{tabular}

Discussion. Jdaidites cultellus differs from the type species in the much wider umbilicus.

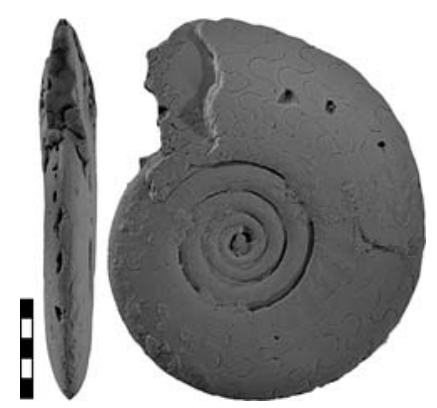

museum-fossilrecord.wiley-vch.de
Figure 11. Jdaidites cultellus n. sp., holotype MB.C.18823 from locality MOU-C4; $\times 2.0$. 


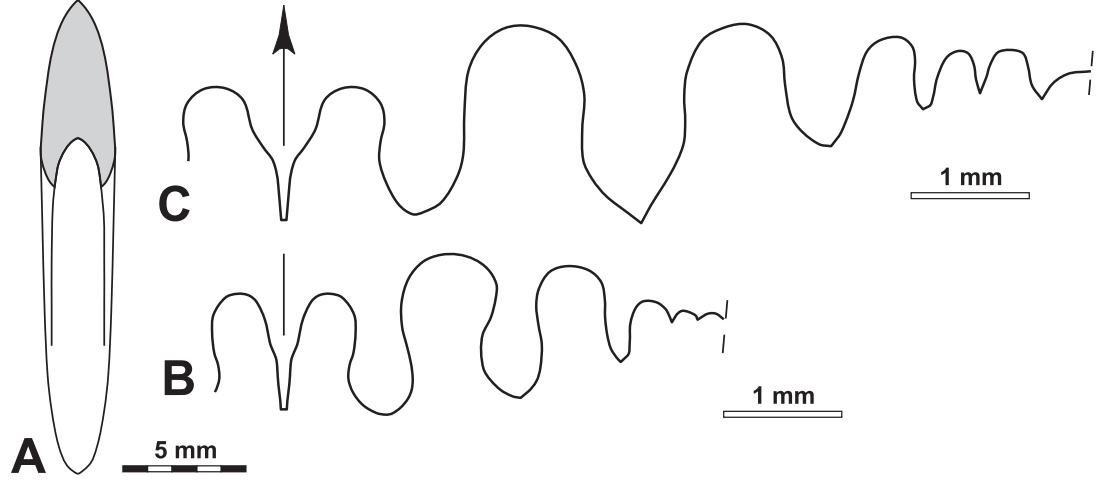

Figure 12. Jdaidites cultellus $\mathrm{n}$. sp. from locality MOU-C4. A. Dorsal view of holotype MB.C. $18823 ; \times 2.5$. B. Suture line of holotype MB.C.18823, at $2.1 \mathrm{~mm} \mathrm{ww}$, $3.6 \mathrm{~mm}$ wh; $\times 12.0$. C. Suture line of the same specimen, at $18.6 \mathrm{~mm} \mathrm{dm}, 2.9 \mathrm{~mm}$ ww, $6.8 \mathrm{~mm}$ wh; $\times 12.0$.

Suborder Goniatitina Hyatt, 1884

Superfamily Pericyclaceae Hyatt, 1900

Family Pericyclidae Hyatt, 1900

Subfamily Pericyclinae Hyatt, 1900

\title{
Pericyclus Mojsisovics, 1882
}

\author{
Type species. Goniatites princeps de Koninck, 1844, p. 579 [OD].
}

Genus definition. Pericyclinae with pachyconic or thickly discoidal conch, reaching up to $70 \mathrm{~mm}$ conch diameter. Conch subinvolute, subevolute or evolute with minor ontogenetic changes. Steinkern with strong, usually sharp ribs with concavo-convex course and rursiradiate direction, rib splitting and rib intercalation common; without or with weak convex or concavo-convex constrictions. Suture line with parallel-sided, very narrow external lobe $(\mathrm{EL} w / \mathrm{d}=0.32-0.42$; $\mathrm{EL} / \mathrm{AL}=0.80-1.30$ ) and low median saddle ( $\mathrm{MS} \mathrm{h}=0.20-0.35$ ); ventrolateral saddle broadly rounded; adventive lobe V-shaped and narrow, slightly asymmetric.

Included species.

circulus: Pericyclus circulus n. sp.; Mouydir, Algeria.

dilatatus: Pericyclus dilatatus Schindewolf, 1926, p. 78; Thuringia.

intercisus: Pericyclus intercisus n. sp.; Mouydir, Algeria.

latumbilicatus: Pericyclus latumbilicatus Kusina, 2000, p. 20; North Urals.

mercatorius: Pericyclus mercatorius Korn, Bockwinkel, Ebbighausen \& Klug 2003, p. 85; Anti-Atlas, Morocco.

princeps: Goniatites princeps de Koninck, 1844, p. 579; Belgium.

tortuosus: Pericyclus tortuosus n. sp.; Mouydir, Algeria.

trochus: Pericyclus trochus n. sp.; Mouydir, Algeria.

Separation of the new species. The four species of Pericyclus from Oued Temertasset can be separated by means of conch morphology and the suture line. In the conch proportions, they differ as follows:

- P. tortuosus - at $15 \mathrm{~mm} \mathrm{dm}$ : mean value of the $\mathrm{uw} / \mathrm{dm}$ ratio $=0.52$; umbilical margin rounded.

- P. circulus - at 20-30 $\mathrm{mm} \mathrm{dm}$ : mean value of the uw $/ \mathrm{dm}$ ratio $=0.45$, of the $\mathrm{ww} / \mathrm{wh}$ ratio $=1.60$; umbilical margin rounded.

- P. trochus - at 20-30 mm dm: mean value of the uw $/ \mathrm{dm}$ ratio $=0.36$, of the ww/wh ratio $=1.40$; umbilical margin subangular.

- P. intercisus - at 20-30 $\mathrm{mm} \mathrm{dm}$ : mean value of the uw/dm ratio $=0.28$, of the ww/wh ratio $=1.20$; umbilical margin subangular.

The steinkern surface offers more differences:

- P. tortuosus - 25-35 very coarse, sharp, slightly biconvex ribs with rursiradiate direction; rib splitting very common; deep steinkern constrictions.

- P. circulus - 30-40 coarse, sharp concavo-convex ribs with rursiradiate direction; rib splitting is rare, splitting occurs on the umbilical margin; adult conchs above $15 \mathrm{~mm}$ usually without constrictions.

- P. trochus - 40-50 coarse, sharp concavo-convex ribs (tendency towards biconvex course) with slightly rursiradiate direction; rib splitting is common, splitting occurs on the inner flank near the umbilicus, intercalatory ribs are introduced in the inner flank area; well-developed constrictions.

- P. intercisus - 50-60 shallow rounded concavo-convex ribs (tendency towards biconvex course) with rursiradiate direction; rib splitting and intercalation very common; splitting occurs on the inner flank; well-developed constrictions.

Discussion. The genus Pericyclus has for long been used as a pool for any ribbed ammonoids of late Tournaisian age, until Turner (1948) and Schindewolf (1951) introduced a number of new genera. The genus must now be defined by its type species P. princeps, meaning that many of the species previously attributed to Pericyclus will now be placed in other genera or even other families.

Pericyclus differs from Goniocyclus Gordon, 1986 in the higher median saddle of the suture line and in the less well-developed ventral sinus of the ribs, which form a chevron-like form in Goniocyclus. Bouhamedites Korn, Bockwinkel, Ebbighausen \& Klug, 2003 differs in the subacute venter and the closure of the umbilicus. Nodopericyclus n. gen. is separated from Pericyclus in the strikingly bifurcating ribs. 


\section{Pericyclus tortuosus n. sp.}

Figures 13, 14

Derivation of name. From Latin tortuosus = full of whorls, because of the wide umbilicus.

Holotype. Specimen MB.C.19026.1, illustrated in Figure 13A.

Type locality and horizon. Oued Temertasset, sample MOU-V (Mouydir, South Algeria); lower part of the Pericyclus-Progoniatites Assemblage. Material. 12 specimens, conch diameter up to $15 \mathrm{~mm}$.

Diagnosis. Pericyclus with thinly to thickly discoidal and evolute conch throughout ontogeny; whorl cross section usually depressed crescentshaped; umbilical margin narrowly rounded; flanks and broad venter widely rounded. Ornament with 25-35 very coarse, sharp ribs extending in rursiradiate direction; rib course slightly biconvex with a shallow ventral sinus; the ribs begin on the umbilical wall; rib splitting is common, splitting occurs on the umbilical margin producing nodes. Steinkern with deep constrictions. Suture line with parallel-sided, very narrow and deep external lobe; median saddle very low, ventrolateral saddle slightly asymmetric, broadly rounded; adventive lobe V-shaped.

Table 16. Conch ontogeny (Figs 14A, C-E) of Pericyclus tortuosus n. sp.

\begin{tabular}{|c|c|c|c|}
\hline$d m$ & conch shape & whorl cross section shape & aperture \\
\hline $2 \mathrm{~mm}$ & $\begin{array}{l}\text { thickly discoidal; evolute } \\
\text { (ww/dm } \sim 0.50 ; \text { uw/dm } \sim 0.58 \text { ) }\end{array}$ & $\begin{array}{l}\text { strongly depressed; moderately embracing } \\
\text { (ww/wh } \sim 2.10 ; \text { IZR } \sim 0.20 \text { ) }\end{array}$ & $\begin{array}{l}\text { low } \\
(\text { WER } \sim 1.50)\end{array}$ \\
\hline $8 \mathrm{~mm}$ & $\begin{array}{l}\text { thickly discoidal; evolute } \\
\text { (ww/dm } \sim 0.50 ; \text { uw/dm } \sim 0.50 \text { ) }\end{array}$ & $\begin{array}{l}\text { moderately depressed; moderately embracing } \\
\text { (ww/wh } \sim 1.75 ; \text { IZR } \sim 0.24 \text { ) }\end{array}$ & $\begin{array}{l}\text { low } \\
(\text { WER 1.60) }\end{array}$ \\
\hline $15 \mathrm{~mm}$ & $\begin{array}{l}\text { thinly discoidal; evolute } \\
\text { (ww/dm } \sim 0.47 ; \text { uw/dm } \sim 0.53 \text { ) }\end{array}$ & $\begin{array}{l}\text { moderately depressed; moderately embracing } \\
\text { (ww/wh } \sim 1.83 ; \text { IZR } \sim 0.20 \text { ) }\end{array}$ & $\begin{array}{l}\text { low } \\
(\text { WER } \sim 1.60)\end{array}$ \\
\hline
\end{tabular}
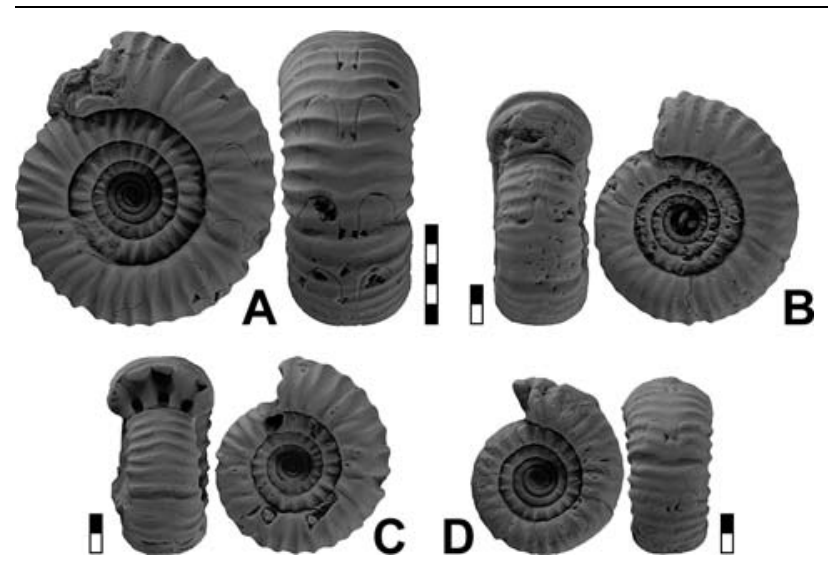

Figure 13. Pericyclus tortuosus n. sp.; all $\times 2$. A. Holotype MB.C.19026.1 from locality MOU-D2. B. Paratype MB.C.19026.2 from locality MOU-V. C. Paratype MB.C.18824 from locality MOU-C4. D. Paratype MB.C.19026.3 from locality MOU-V.
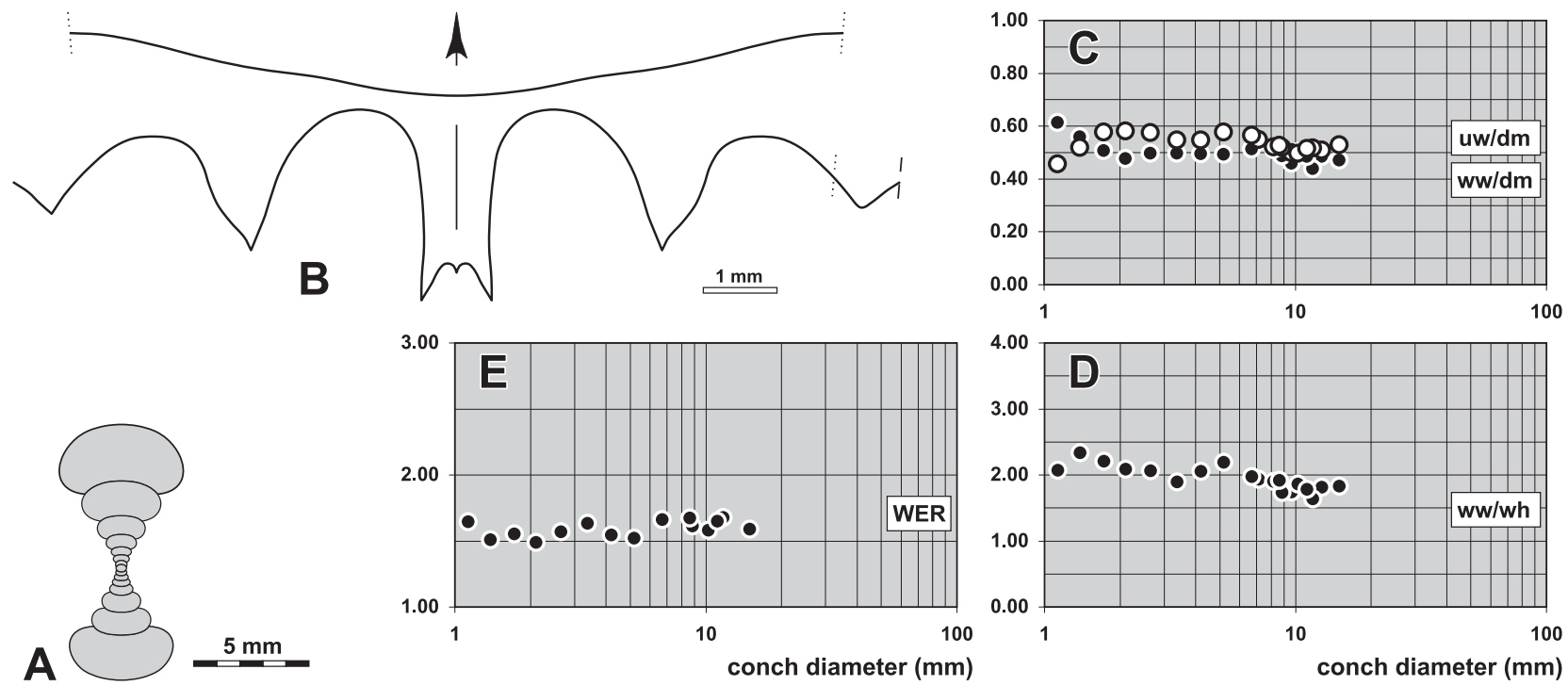

Figure 14. Pericyclus tortuosus n. sp. A. Cross section of paratype MB.C.19026.4 from locality MOU-V; $\times 2.5$. B. Suture line and rib course of holotype MB.C.19026.1 from locality MOU-V, at $14.3 \mathrm{~mm} \mathrm{dm}, 6.5 \mathrm{~mm}$ ww, $3.7 \mathrm{~mm}$ wh; $\times 8.0$. C-E. Ontogenetic development of the conch width index (ww/dm), umbilical width index (uw/dm), whorl width index (ww/wh), and whorl expansion rate (WER) of all available specimens. 
Table 17. Conch dimensions (in $\mathrm{mm}$ ) and proportions for reference specimens of Pericyclus tortuosus $\mathrm{n}$. sp.

\begin{tabular}{|c|c|c|c|c|c|c|c|c|c|c|}
\hline & $\mathrm{dm}$ & ww & wh & uw & ah & ww/dm & ww/wh & $\mathrm{uw} / \mathrm{dm}$ & WER & IZR \\
\hline holotype MB.C.19026.1 & 15.0 & 7.0 & 3.8 & 7.9 & 3.1 & 0.47 & 1.83 & 0.53 & 1.59 & 0.19 \\
\hline paratype MB.C.19026.2 & 11.7 & 5.1 & 3.1 & 6.1 & 2.7 & 0.44 & 1.64 & 0.52 & 1.68 & 0.15 \\
\hline paratype MB.C.18824 & 10.2 & 5.2 & 2.8 & 5.1 & 2.1 & 0.50 & 1.87 & 0.50 & 1.58 & 0.24 \\
\hline paratype MB.C.19026.3 & 8.8 & 4.3 & 2.5 & 4.6 & 1.9 & 0.49 & 1.74 & 0.52 & 1.61 & 0.24 \\
\hline
\end{tabular}

Table 18. Suture line proportions (Fig. 14B) for Pericyclus tortuosus n. sp.

\begin{tabular}{llllllll}
\hline specimen & at dm & EL w/d & EL/VLS & EL/AL & MS h & VLS w/h & remarks \\
\hline holotype MB.C.19026.1 & $14.3 \mathrm{~mm}$ & 0.36 & 0.45 & 0.98 & 0.19 & 0.80 & A lobe small, E lobe very deep \\
\hline
\end{tabular}

Discussion. Pericyclus tortuosus has a much wider umbilicus than the other species of the genus, with an uw/dm ratio higher than 0.50 throughout ontogeny. The adult stage of P. circulus resembles $P$. tortuosus, but this species has a subevolute intermediate growth stage (uw $/ \mathrm{dm}=0.33-0.42$ at $8 \mathrm{~mm} \mathrm{dm}$ ). P. latumbilicatus closely resembles P. tortuosus, but it possesses a much wider external lobe and a narrower umbilicus $(\mathrm{uw} / \mathrm{dm}=0.47)$.

\section{Pericyclus circulus n. sp.}

Figures 15, 16

Derivation of name. From Latin circulus = ring, because of the ornamented conch.

Holotype. Specimen MB.C.18862.1, illustrated in Figure 15B.

Type locality and horizon. Oued Temertasset, locality and sample MOU-D1 (Mouydir, South Algeria); upper Pericyclus-Progoniatites Assemblage.

Material. 332 specimens, conch diameter up to $36 \mathrm{~mm}$.

Diagnosis. Pericyclus with thinly pachyconic and subevolute conch up to $10 \mathrm{~mm} \mathrm{dm}$; thereafter becoming thickly discoidal and evolute; whorl cross section usually depressed crescent-shaped; umbilical margin narrowly rounded; flanks and venter widely rounded. Ornament with $30-40$ coarse, sharp ribs extending in rursiradiate direction; rib course concavo-convex with a shallow subangular ventral sinus; the ribs begin on the umbilical wall; rib splitting is rare, splitting occurs on the umbilical margin. Steinkern with constrictions in the juvenile stage, adult conch above $15 \mathrm{~mm}$ dm usually without constrictions. Suture line with parallel-sided, very narrow and deep external lobe; median saddle low, ventrolateral saddle slightly asymmetric, broadly rounded; adventive lobe V-shaped, narrow.

Table 19. Conch ontogeny (Figs $16 \mathrm{~A}-\mathrm{D}, \mathrm{G}-\mathrm{J}$ ) of Pericyclus circulus $\mathrm{n}$. sp.

\begin{tabular}{|c|c|c|c|}
\hline$d m$ & conch shape & whorl cross section shape & aperture \\
\hline $2 \mathrm{~mm}$ & $\begin{array}{l}\text { thinly pachyconic; subevolute } \\
(\mathrm{ww} / \mathrm{dm}=0.60-0.68 ; \mathrm{uw} / \mathrm{dm}=0.30-0.45)\end{array}$ & $\begin{array}{l}\text { moderately to strongly depressed; moderately } \\
\text { embracing ( } w w / w h=1.60-2.10 ; \mid Z R=0.20-0.30 \text { ) }\end{array}$ & $\begin{array}{l}\text { low } \\
(\text { WER }=1.55-1.70)\end{array}$ \\
\hline $8 \mathrm{~mm}$ & $\begin{array}{l}\text { thinly pachyconic; subevolute } \\
(\mathrm{ww} / \mathrm{dm}=0.60-0.72 ; \mathrm{uw} / \mathrm{dm}=0.33-0.42)\end{array}$ & $\begin{array}{l}\text { moderately to strongly depressed; strongly } \\
\text { embracing ( } w w / w h=1.60-2.10 ; \mid Z R=0.35-0.40 \text { ) }\end{array}$ & $\begin{array}{l}\text { low } \\
(\text { WER }=1.55-1.70)\end{array}$ \\
\hline $20 \mathrm{~mm}$ & $\begin{array}{l}\text { thinly to thickly discoidal; subevolute to evolute } \\
(\mathrm{ww} / \mathrm{dm}=0.45-0.60 ; \mathrm{uw} / \mathrm{dm}=0.40-0.52)\end{array}$ & $\begin{array}{l}\text { weakly to moderately depressed; moderately to } \\
\text { strongly embracing } \\
\text { (ww/wh }=1.40-2.00 ; \text { IZR }=0.25-0.45 \text { ) }\end{array}$ & $\begin{array}{l}\text { low } \\
(\text { WER }=1.50-1.70)\end{array}$ \\
\hline $30 \mathrm{~mm}$ & $\begin{array}{l}\text { thinly to thickly discoidal; subevolute to evolute } \\
\text { (ww/dm }=0.42-0.52 ; \mathrm{uw} / \mathrm{dm}=0.40-0.52 \text { ) }\end{array}$ & $\begin{array}{l}\text { weakly to moderately depressed; moderately to } \\
\text { strongly embracing } \\
\text { (ww/wh }=1.40-1.80 ; \mathrm{IZR}=0.20-0.40 \text { ) }\end{array}$ & $\begin{array}{l}\text { low } \\
(\text { WER }=1.50-1.70)\end{array}$ \\
\hline
\end{tabular}

Table 20. Conch dimensions (in $\mathrm{mm}$ ) and proportions for reference specimens of Pericyclus circulus n. sp.

\begin{tabular}{|c|c|c|c|c|c|c|c|c|c|c|}
\hline & $\mathrm{dm}$ & ww & wh & uw & ah & $w w / d m$ & ww/wh & $\mathrm{uw} / \mathrm{dm}$ & WER & IZR \\
\hline paratype MB.C.18886.1 & 35.2 & 17.0 & 10.1 & 16.5 & 7.9 & 0.48 & 1.69 & 0.47 & 1.66 & 0.22 \\
\hline holotype MB.C.18862.1 & 30.3 & 15.2 & 8.7 & 14.3 & 6.4 & 0.50 & 1.74 & 0.47 & 1.61 & 0.27 \\
\hline paratype MB.C.18743.1 & 23.7 & 11.9 & 6.8 & 11.2 & 4.7 & 0.50 & 1.73 & 0.47 & 1.55 & 0.31 \\
\hline paratype MB.C.18862.4 & 20.4 & 11.0 & 6.6 & 9.3 & 4.4 & 0.54 & 1.68 & 0.46 & 1.62 & 0.33 \\
\hline paratype MB.C.18862.2 & 15.6 & 9.1 & 5.8 & 6.0 & 3.3 & 0.58 & 1.55 & 0.38 & 1.61 & 0.43 \\
\hline paratype MB.C.18862.3 & 12.3 & 7.9 & 4.5 & 4.8 & 2.7 & 0.65 & 1.75 & 0.39 & 1.64 & 0.40 \\
\hline
\end{tabular}


Table 21. Suture line proportions (Figs 16E, F) for Pericyclus circulus n. sp.

\begin{tabular}{llllllll}
\hline specimen & at dm & EL w/d & EL/NLS & EL/AL & MS h & VLS w/h & remarks \\
\hline holotype MB.C.18862.1 & $28.0 \mathrm{~mm}$ & 0.36 & 0.53 & 1.30 & 0.33 & 0.67 & A lobe small, E lobe very deep \\
paratype MB.C.18886.2 & c. $18.0 \mathrm{~mm}$ & 0.36 & 0.52 & 0.97 & 0.24 & 0.69 & \\
\hline
\end{tabular}

Discussion. Pericyclus circulus has a conch shape similar to P. latumbilicatus $(\mathrm{ww} / \mathrm{dm}=0.42, \mathrm{uw} / \mathrm{dm}=0.47$ at $21 \mathrm{~mm} \mathrm{dm})$, but is stouter $(\mathrm{ww} / \mathrm{dm}=0.45-0.60, \mathrm{uw} / \mathrm{dm}=0.40-0.52$ at the same diameter in $P$. circulus $)$. Furthermore, P. latumbilicatus possesses, unlike P. circulus, strong steinkern constrictions.
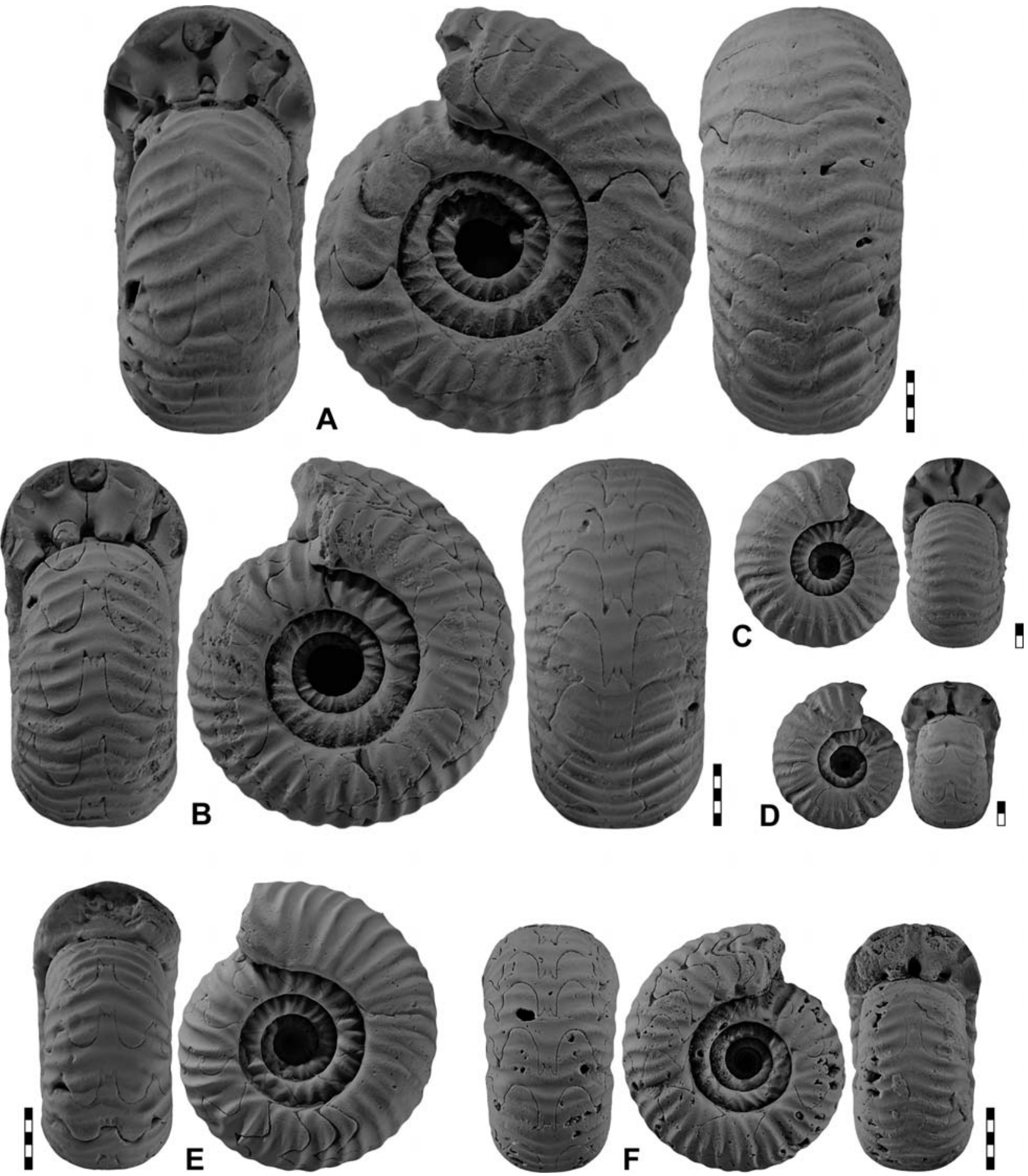

Figure 15. Pericyclus circulus $n$. sp.; all $\times 2$. A. Paratype MB.C.18886.1 from locality MOU-D2. B. Holotype MB.C.18862.1 from locality MOU-D1. C. Paratype MB.C.18862.2 from locality MOU-D1. D. Paratype MB.C.18862.3 from locality MOU-D1. E. Paratype MB.C.18743.1 from locality A321. F. Paratype MB.C.18862.4 from locality MOU-D1. 

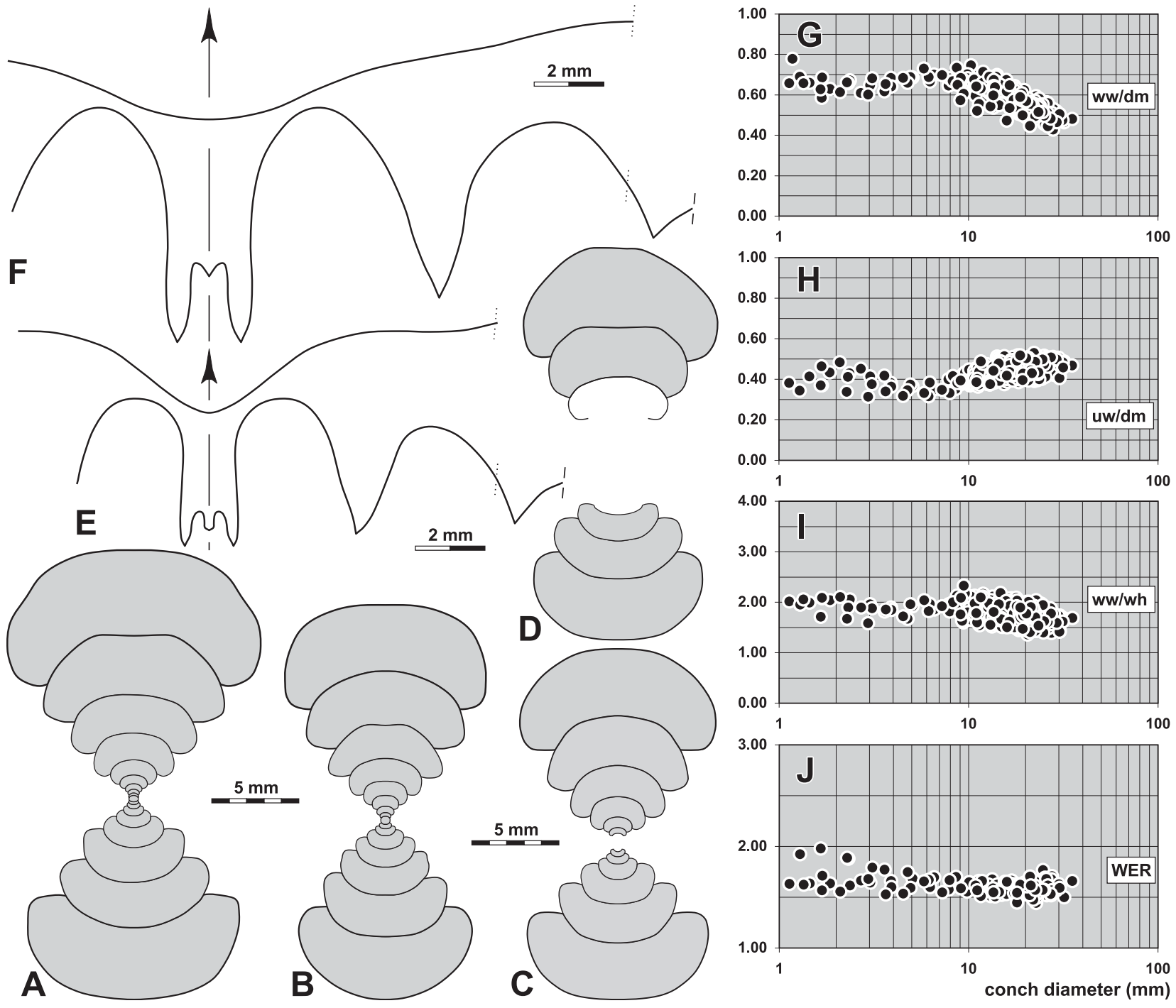

Figure 16. Pericyclus circulus n. sp. A. Cross section of paratype MB.C.18862.5 from locality MOU-D1; $\times 2.5$. B. Cross section of paratype MB.C.18862.6 from locality MOU-D1; $\times 2.5$. C. Cross section of paratype MB.C.18862.7 from locality MOU-D1; $\times 2.5$. D. Cross section of paratype MB.C.18929 from locality MOU-E05; $\times 2.5$. E. Suture line and rib course of paratype MB.C.18886.2 from locality MOU-D2, at $11.2 \mathrm{~mm} \mathrm{ww}, 8.1 \mathrm{~mm}$ wh; $\times 5.0$. F. Suture line and rib course of holotype MB.C.18862.1 from locality MOU-D1, at $28.0 \mathrm{~mm} \mathrm{dm}, 14.8 \mathrm{~mm} w w, 8.8 \mathrm{~mm}$ wh; $\times 5.0$. G-J. Ontogenetic development of the conch width index (ww/dm), umbilical width index (uw/dm), whorl width index (ww/wh), and whorl expansion rate (WER) of all available specimens.

\section{Pericyclus trochus n. sp.}

Figures 17, 18

Derivation of name. From Latin trochus $=$ a wheel ornamented with rings, because of the ornamentation.

Holotype. Specimen MB.C.18863.1, illustrated in Figure 17C.

Type locality and horizon. Oued Temertasset, locality and sample MOU-D1 (Mouydir, South Algeria); upper Pericyclus-Progoniatites Assemblage.

Material. 494 specimens, conch diameter up to $36 \mathrm{~mm}$.

Diagnosis. Pericyclus with thinly pachyconic conch up to $10 \mathrm{~mm} \mathrm{dm}$, thereafter becoming thickly discoidal; conch subevolute throughout ontogeny except for a subinvolute interval between 3 and $10 \mathrm{~mm} \mathrm{dm}$; whorl cross section crescent-shaped to circular; umbilical margin subangular; flanks and venter broadly rounded. Ornament with 40-50 coarse, sharp ribs extending in a slightly rursiradiate direction; rib course concavoconvex with tendency to biconvexity with a shallow subangular ventral sinus; the ribs begin outside the umbilical wall; rib splitting is common, splitting occurs on the inner flank near the umbilicus, intercalatory ribs introduced in the inner flank area. Steinkern with well-developed constrictions. Suture line with parallel-sided, very narrow and deep external lobe; median saddle very low or low, ventrolateral saddle slightly asymmetric, broadly rounded; adventive lobe V-shaped, narrow. 
Table 22. Conch ontogeny (Figs 18A-D, G-J) of Pericyclus trochus n. sp.

\begin{tabular}{|c|c|c|c|}
\hline$d m$ & conch shape & whorl cross section shape & aperture \\
\hline $2 \mathrm{~mm}$ & $\begin{array}{l}\text { thinly to thickly pachyconic; subevolute } \\
\text { (ww/dm }=0.60-0.75 ; u w / d m=0.35-0.45)\end{array}$ & $\begin{array}{l}\text { moderately to strongly depressed; strongly } \\
\text { embracing ( } w w / w h=1.70-2.10 ; \mathrm{IZR}=0.30-0.40 \text { ) }\end{array}$ & $\begin{array}{l}\text { low to moderate } \\
(\mathrm{WER}=1.60-1.80)\end{array}$ \\
\hline $8 \mathrm{~mm}$ & $\begin{array}{l}\text { thinly pachyconic; subinvolute to subevolute } \\
\text { (ww/dm }=0.60-0.72 ; u w / d m=0.25-0.35 \text { ) }\end{array}$ & $\begin{array}{l}\text { moderately depressed; strongly embracing } \\
(\mathrm{ww} / \mathrm{wh}=1.50-1.90 ; \mathrm{IZR}=0.35-0.45)\end{array}$ & $\begin{array}{l}\text { low to moderate } \\
(\text { WER }=1.60-1.80)\end{array}$ \\
\hline $20 \mathrm{~mm}$ & $\begin{array}{l}\text { thickly discoidal; subevolute } \\
(\mathrm{ww} / \mathrm{dm}=0.48-0.60 ; \mathrm{ww} / \mathrm{dm}=0.30-0.45 \text { ) }\end{array}$ & $\begin{array}{l}\text { weakly to moderately depressed; strongly } \\
\text { embracing (ww/wh }=1.25-1.80 ; \mathrm{IZR}=0.30-0.45 \text { ) }\end{array}$ & $\begin{array}{l}\text { low to moderate } \\
(\mathrm{WER}=1.50-1.80)\end{array}$ \\
\hline $30 \mathrm{~mm}$ & $\begin{array}{l}\text { thickly discoidal; subevolute } \\
(\mathrm{ww} / \mathrm{dm}=0.48-0.60 ; \mathrm{uw} / \mathrm{dm}=0.30-0.45)\end{array}$ & $\begin{array}{l}\text { weakly to moderately depressed; strongly } \\
\text { embracing (ww/wh }=1.10-1.60 ; \text { IZR }=0.30-0.45 \text { ) }\end{array}$ & $\begin{array}{l}\text { low } \\
(\text { WER }=1.50-1.70)\end{array}$ \\
\hline
\end{tabular}

Table 23. Conch dimensions (in $\mathrm{mm}$ ) and proportions for reference specimens of Pericyclus trochus n. sp.

\begin{tabular}{|c|c|c|c|c|c|c|c|c|c|c|}
\hline & $\mathrm{dm}$ & wW & wh & uw & ah & $w w / d m$ & ww/wh & $\mathrm{uw} / \mathrm{dm}$ & WER & IZR \\
\hline paratype MB.C.18863.2 & 26.1 & 12.9 & 8.2 & 10.1 & 5.1 & 0.50 & 1.57 & 0.39 & 1.55 & 0.38 \\
\hline holotype MB.C.18863.1 & 22.2 & 12.5 & 7.4 & 8.7 & 4.9 & 0.56 & 1.68 & 0.39 & 1.65 & 0.34 \\
\hline paratype MB.C.18863.3 & 22.0 & 11.1 & 8.2 & 8.5 & 4.9 & 0.50 & 1.36 & 0.38 & 1.65 & 0.40 \\
\hline paratype MB.C.18863.4 & 22.0 & 11.4 & 7.9 & 8.0 & 5.0 & 0.52 & 1.44 & 0.37 & 1.68 & 0.37 \\
\hline
\end{tabular}

Table 24. Suture line proportions (Figs 18E, F) for Pericyclus trochus n. sp.

\begin{tabular}{llllllll}
\hline specimen & at $\mathrm{dm}$ & EL w/d & EL/VLS & EL/AL & MS h & VLS w/h & remarks \\
\hline paratype MB.C.18863.9 & $30.1 \mathrm{~mm}$ & 0.32 & 0.54 & 0.81 & 0.27 & 0.60 \\
holotype MB.C.18863.1 & $20.1 \mathrm{~mm}$ & 0.38 & 0.62 & 1.08 & 0.18 & 0.61 \\
\hline
\end{tabular}

Discussion. Pericyclus trochus resembles P. princeps in the conch proportions $(\mathrm{ww} / \mathrm{dm}=0.53, \mathrm{uw} / \mathrm{dm}=0.31$ at $35 \mathrm{~mm} \mathrm{dm}$ ), but differs in the much more pronounced ventral sinus of the ribs and the much weaker constrictions.

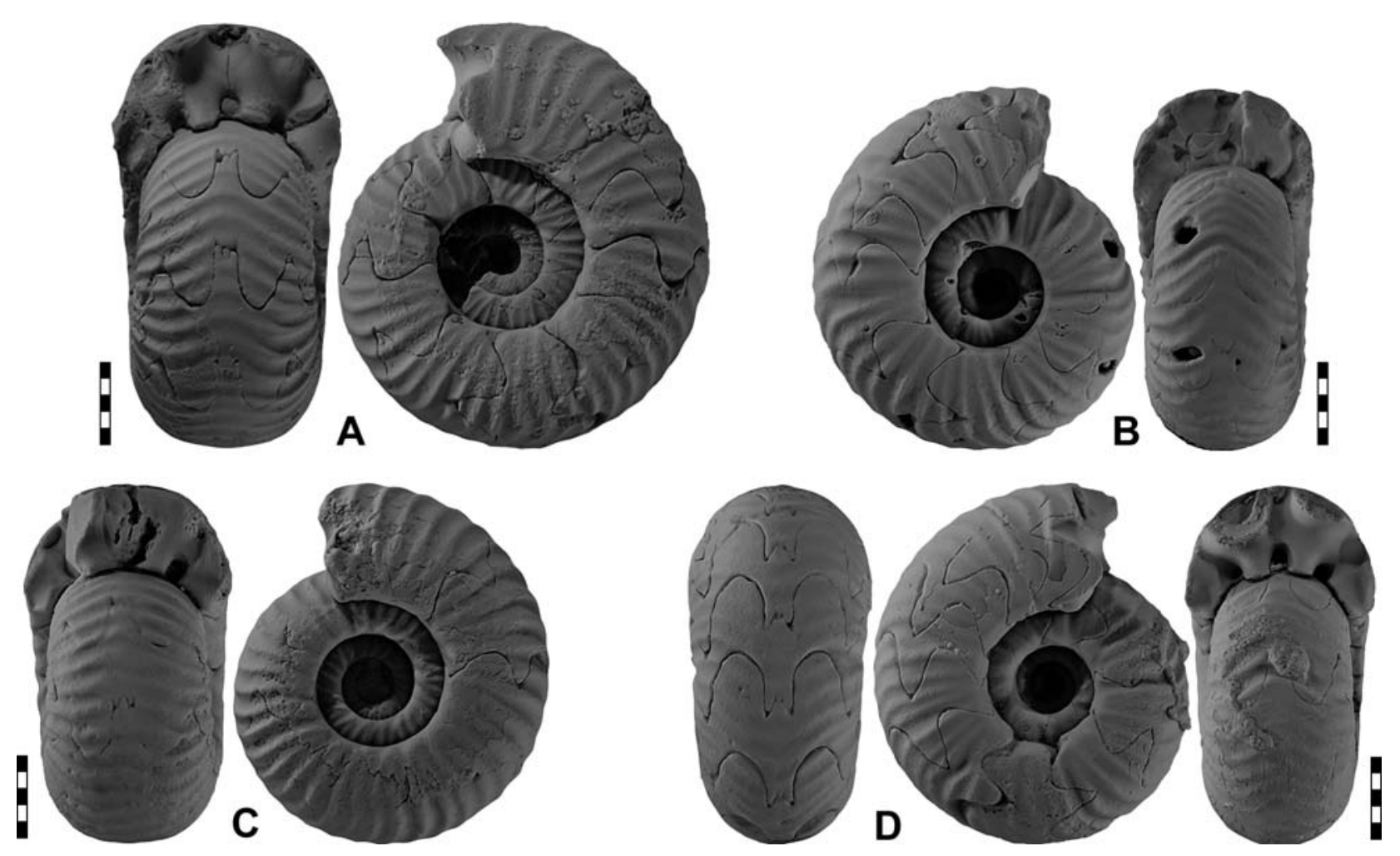

Figure 17. Pericyclus trochus n. sp. from locality MOU-D1; all ×2. A. Paratype MB.C.18863.2. B. Paratype MB.C.18863.3. C. Holotype MB.C.18863.1. D. Paratype MB.C.18863.4. 

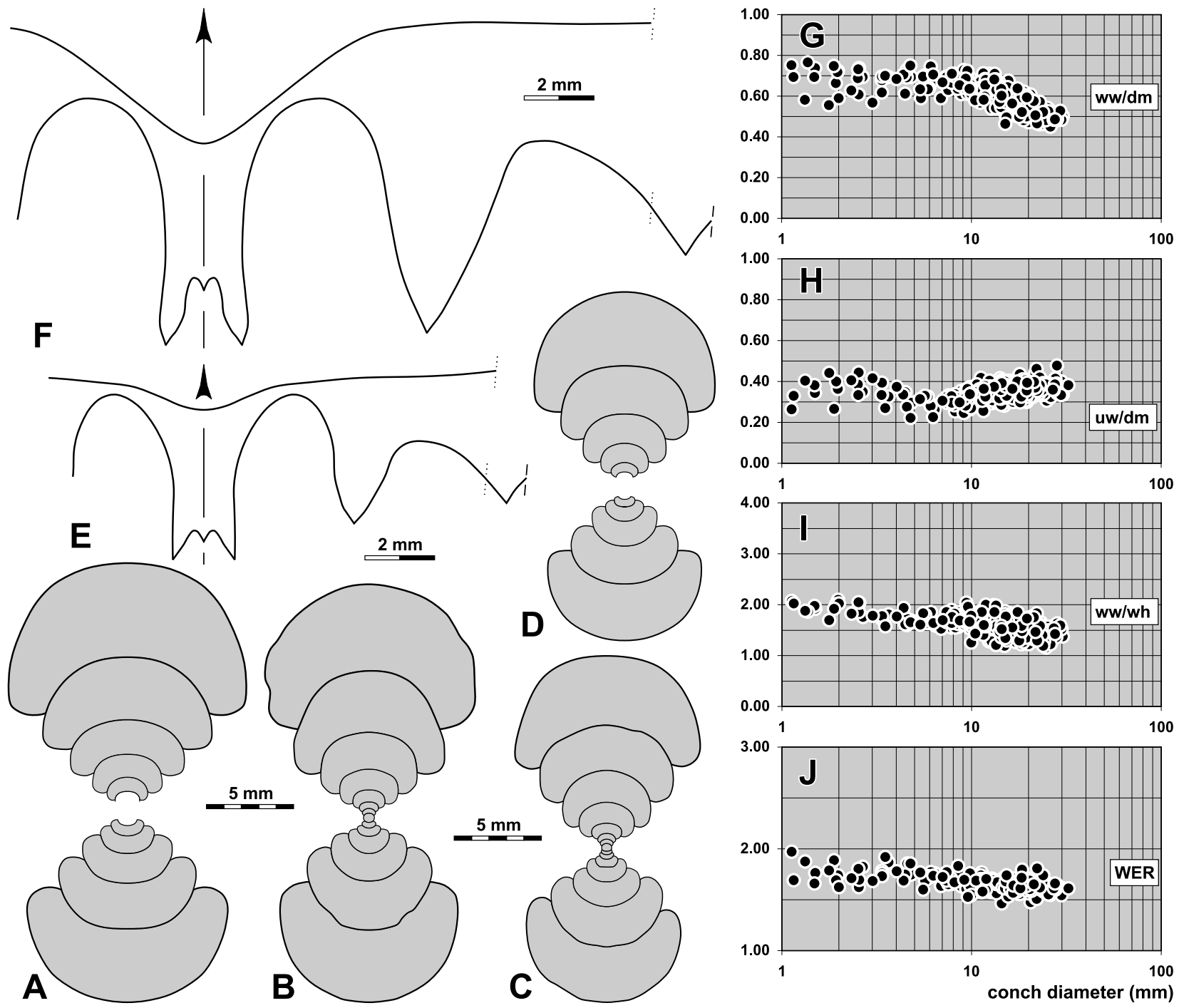

Figure 18. Pericyclus trochus n. sp. from locality MOU-D1. A. Cross section of paratype MB.C.18863.5; $\times 2.5$. B. Cross section of paratype MB.C.18863.6; $\times 2.5$. C. Cross section of paratype MB.C.18863.7; $\times 2.5$. D. Cross section of paratype MB.C.18863.8; $\times 2.5$. E. Suture line and rib course of holotype MB.C.18863.1, at $20.1 \mathrm{~mm} \mathrm{dm}, 11.7 \mathrm{~mm}$ ww, $7.2 \mathrm{~mm}$ wh; $\times 5.0$. F. Suture line and rib course of paratype MB.C.18863.9, at $30.1 \mathrm{~mm} \mathrm{dm}, 13.9 \mathrm{~mm}$ ww, $11.2 \mathrm{~mm}$ wh; $\times 5.0$. G-J. Ontogenetic development of the conch width index $(\mathrm{ww} / \mathrm{dm})$, umbilical width index (uw/dm), whorl width index (ww/wh), and whorl expansion rate (WER) of all available specimens.

\section{Pericyclus intercisus n. sp.}

Figures 19, 20

Derivation of name. From Latin intercisus = interrupted, because of the lack of ribs on the venter.

Holotype. Specimen MB.C.18864.1, illustrated in Figure 19D.

Type locality and horizon. Oued Temertasset, locality and sample MOU-D1 (Mouydir, South Algeria); upper Pericyclus-Progoniatites Assemblage.

Material. 371 specimens, conch diameter up to $31 \mathrm{~mm}$.

Diagnosis. Pericyclus with thinly or thickly pachyconic conch up to $10 \mathrm{~mm} \mathrm{dm}$, thereafter becoming thinly discoidal at $30 \mathrm{~mm} \mathrm{dm}$; conch subevolute in the juvenile stage and subinvolute or subevolute above $4 \mathrm{~mm} \mathrm{dm}$; whorl cross section in adults circular to subcircular; umbilical margin subangular; flanks and venter broadly rounded. Ornament with 50-60 shallow ribs; rib course concavo-convex with tendency to biconvexity with a moderately deep ventral sinus, direction rursiradiate; the ribs begin outside the umbilical wall; rib splitting and intercalation very common; splitting occurs on the inner flank. Steinkern with well-developed constrictions. Suture line with parallel-sided or V-shaped, very narrow external lobe; median saddle low, ventrolateral saddle asymmetric, broadly rounded; adventive lobe V-shaped, asymmetric with stronger curved ventral flank. 

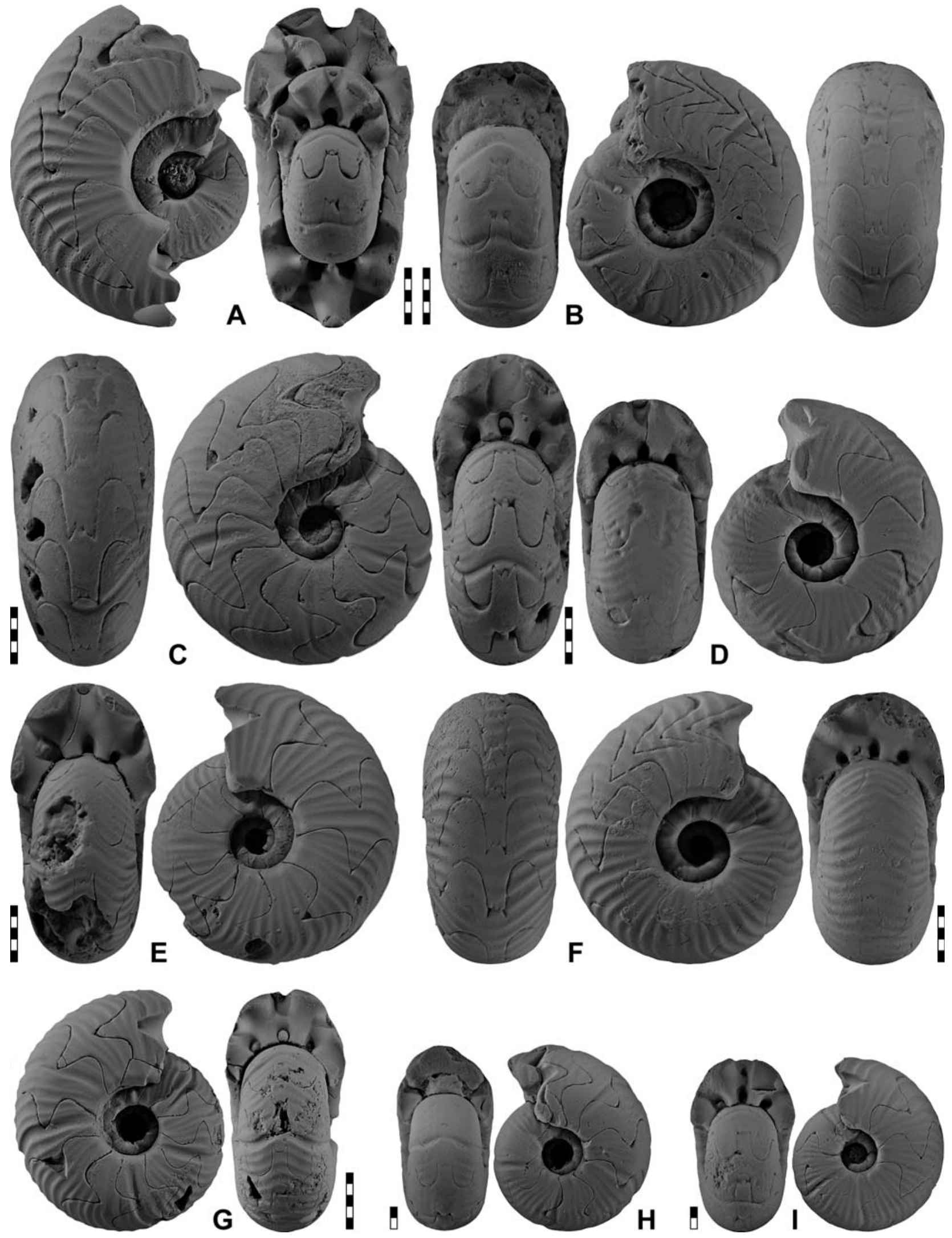

Figure 19. Pericyclus intercisus n. sp.; all $\times 2$. A. Paratype MB.C.19056.1 from locality MOU-Z. B. Paratype MB.C.18864.2 from locality MOU-D1. C. Paratype MB.C.18864.3 from locality MOU-D1. D. Holotype MB.C.18864.1 from locality MOUD1. E. Paratype MB.C.18864.4 from locality MOU-D1. F. Paratype MB.C.18888.1 from locality MOU-D2. G. Paratype MB.C.18864.5 from locality MOU-D1. H. Paratype MB.C.18864.7 from locality MOU-D1. I. Paratype MB.C.18864.6 from locality MOU-D1. 

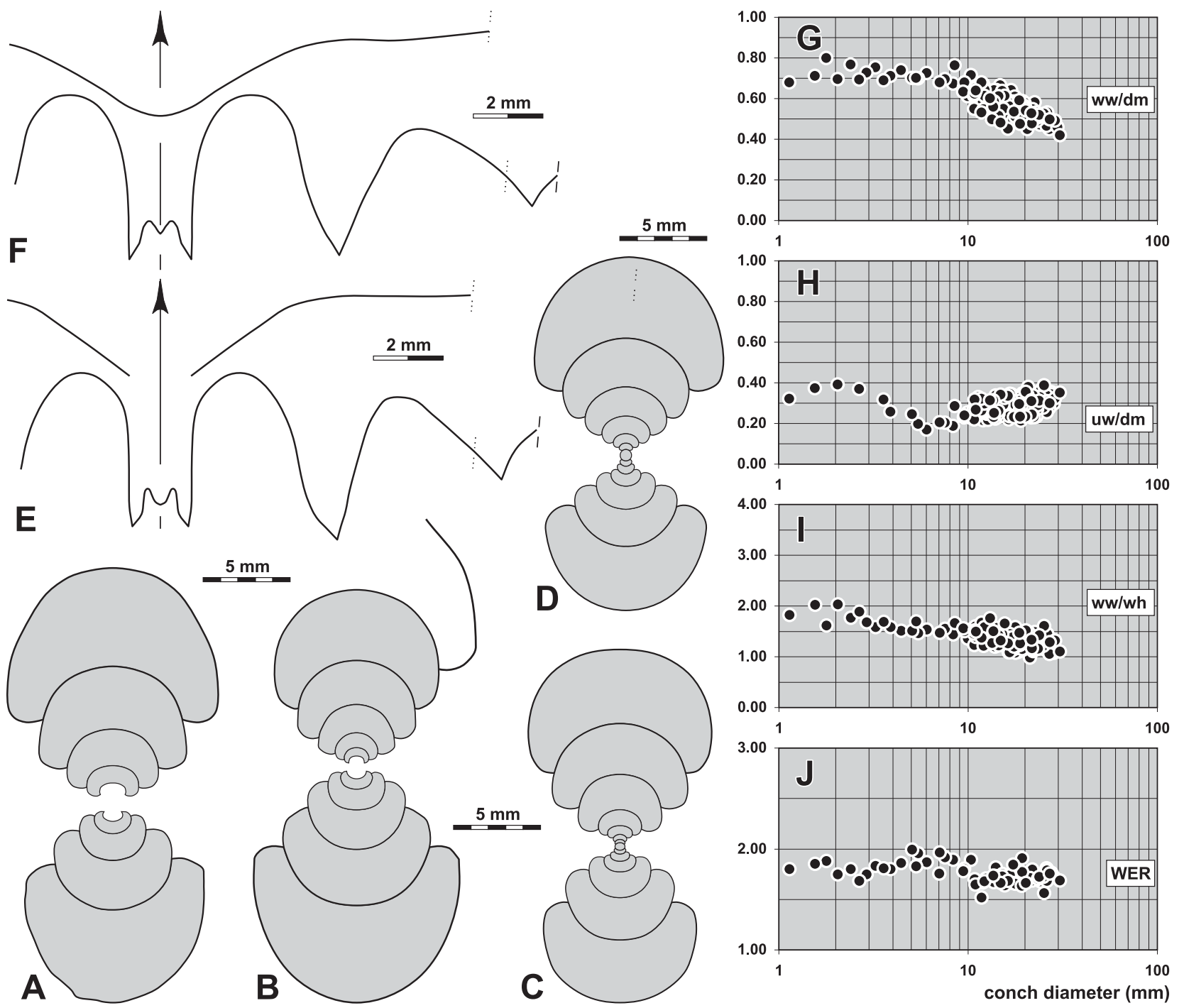

Figure 20. Pericyclus intercisus n. sp. A. Cross section of paratype MB.C.18864.8 from locality MOU-D1; $\times 2.5$. B. Cross section of paratype MB.C.18864.9 from locality MOU-D1; × 2.5. C. Cross section of paratype MB.C.18864.10 from locality MOU-D1; $\times 2.5$. D. Cross section of paratype MB.C. 19056.2 from locality MOU-D1; $\times 2.5$. E. Suture line and rib course of paratype MB.C.19056.1 from locality MOU-Z, at $11.9 \mathrm{~mm}$ ww, $10.2 \mathrm{~mm}$ wh; $\times 5.0$. F. Suture line and rib course of holotype MB.C.18864.1 from locality MOU-D1, at $21.9 \mathrm{~mm} \mathrm{dm}, 11.9 \mathrm{~mm}$ ww, $7.7 \mathrm{~mm} \mathrm{wh} \times 5.0$. G-J. Ontogenetic development of the conch width index (ww/dm), umbilical width index (uw/dm), whorl width index (ww/wh), and whorl expansion rate (WER) of all available specimens.

Table 25. Conch ontogeny (Figs 20A-D, G-J) of Pericyclus intercisus n. sp.

\begin{tabular}{|c|c|c|c|}
\hline $\mathrm{dm}$ & conch shape & whorl cross section shape & aperture \\
\hline $2 \mathrm{~mm}$ & $\begin{array}{l}\text { thickly pachyconic; subevolute } \\
(\mathrm{ww} / \mathrm{dm}=0.70-0.80 ; \mathrm{uw} / \mathrm{dm}=0.35-0.40)\end{array}$ & $\begin{array}{l}\text { moderately depressed; strongly embracing } \\
(\mathrm{ww} / \mathrm{wh}=1.60-2.00 ; \mathrm{IZR}=0.30-0.40)\end{array}$ & $\begin{array}{l}\text { moderate } \\
(\text { WER }=1.75-1.90)\end{array}$ \\
\hline $8 \mathrm{~mm}$ & $\begin{array}{l}\text { thinly to thickly pachyconic; subinvolute } \\
(\mathrm{ww} / \mathrm{dm}=0.65-0.75 ; \mathrm{uw} / \mathrm{dm}=0.20-0.30)\end{array}$ & $\begin{array}{l}\text { weakly or moderately depressed; strongly } \\
\text { embracing } \\
(\text { ww/wh }=1.40-1.70 ; \mathrm{IZR}=0.35-0.45)\end{array}$ & $\begin{array}{l}\text { moderate } \\
(\mathrm{WER}=1.75-1.95)\end{array}$ \\
\hline $20 \mathrm{~mm}$ & $\begin{array}{l}\text { thinly to thickly discoidal; subinvolute to subevolute } \\
\text { (ww/dm }=0.45-0.60 ; u w / d m=0.20-0.35 \text { ) }\end{array}$ & $\begin{array}{l}\text { weakly depressed; strongly embracing } \\
(\mathrm{ww} / \mathrm{wh}=1.00-1.50 ; \mathrm{IZR}=0.30-0.45)\end{array}$ & $\begin{array}{l}\text { low to moderate } \\
\text { (WER }=1.65-1.90)\end{array}$ \\
\hline $30 \mathrm{~mm}$ & $\begin{array}{l}\text { thinly to thickly discoidal; subevolute } \\
(\mathrm{w} w / \mathrm{dm}=0.40-0.50 ; \mathrm{w} / \mathrm{dm}=0.30-0.35)\end{array}$ & $\begin{array}{l}\text { weakly depressed; strongly embracing } \\
\text { (ww/wh }=1.00-1.40 ; \mathrm{IZR}=0.30-0.45 \text { ) }\end{array}$ & $\begin{array}{l}\text { low to moderate } \\
\text { (WER }=1.65-1.80)\end{array}$ \\
\hline
\end{tabular}


Table 26. Conch dimensions (in $\mathrm{mm}$ ) and proportions for reference specimens of Pericyclus intercisus $\mathrm{n}$. sp.

\begin{tabular}{|c|c|c|c|c|c|c|c|c|c|c|}
\hline & $\mathrm{dm}$ & ww & wh & uw & ah & ww/dm & ww/wh & $\mathrm{uw} / \mathrm{dm}$ & WER & IZR \\
\hline paratype MB.C.18864.3 & 28.4 & 13.1 & 12.1 & 8.4 & 6.8 & 0.46 & 1.08 & 0.30 & 1.72 & 0.44 \\
\hline paratype MB.C.18864.4 & 25.0 & 12.7 & 10.4 & 6.9 & 6.0 & 0.51 & 1.22 & 0.28 & 1.72 & 0.43 \\
\hline holotype MB.C.18864.1 & 24.2 & 12.4 & 9.4 & 8.1 & 5.5 & 0.51 & 1.32 & 0.34 & 1.68 & 0.41 \\
\hline paratype MB.C.18864.2 & 24.0 & 12.2 & 8.6 & 7.9 & 5.6 & 0.51 & 1.42 & 0.33 & 1.70 & 0.35 \\
\hline paratype MB.C.18864.5 & 21.8 & 11.0 & 9.6 & 6.3 & 5.6 & 0.50 & 1.14 & 0.29 & 1.80 & 0.42 \\
\hline paratype MB.C.18864.7 & 16.7 & 8.6 & 7.4 & 4.3 & 4.0 & 0.52 & 1.17 & 0.26 & 1.74 & 0.45 \\
\hline paratype MB.C.18864.6 & 15.2 & 9.2 & 6.8 & 3.8 & 3.7 & 0.60 & 1.35 & 0.25 & 1.75 & 0.45 \\
\hline
\end{tabular}

Table 27. Suture line proportions (Figs 20E, F) for Pericyclus intercisus n. sp.

\begin{tabular}{llllllll}
\hline specimen & at dm & EL w/d & EL/VLS & EL/AL & MS h & VLS w/h & remarks \\
\hline holotype MB.C.18864.1 & $21.9 \mathrm{~mm}$ & 0.41 & 0.63 & 0.91 & 0.23 & 0.66 & flanks of E lobe slightly diverging \\
paratype MB.C.19056.1 & c. $19.0 \mathrm{~mm}$ & 0.41 & 0.61 & 1.02 & 0.29 & 0.68 & E lobe parallel-sided \\
\hline
\end{tabular}

Discussion. Pericyclus princeps has a similar conch morphology, but differs in the much sharper ribs from $P$. intercisus. P. intercisus shows some resemblance to species of the genus Temertassetia, such as Temertassetia secunda and Temertassetia decorata. Both species, however, possess weaker ribs and differ mainly in the suture line, which in the genus Temertassetia possesses a V-shaped external lobe with sinuous flanks.

P. mercatorius from the Anti-Atlas of Morocco has a similar conch and ornament, but differs in the lack of steinkern constrictions in the adult stage from the new species.

\section{Nodopericyclus n. gen.}

Derivation of name. After the type species.

Type species. Nodopericyclus circumnodosus n. sp.

Genus definition. Pericyclinae with small conch, reaching approximately $40 \mathrm{~mm}$ diameter; conch ontogeny simple, conch thinly pachyconic and subevolute, aperture low; umbilical margin angular, venter broadly rounded. Ornament with sharp biconvex ribs and intercalatory riblets; biconvex constrictions of the internal mould. Suture line with parallel-sided, very narrow external lobe (EL w/d $\sim 0.40$; EL/AL $\sim 0.80)$ with straight or incurved flanks and very low median saddle (MS $\mathrm{h} \sim 0.18$ ); ventrolateral saddle broadly rounded; adventive lobe V-shaped, almost symmetric and acute.

\section{Included species.}

circumnodosus: Nodopericyclus circumnodosus n. sp.; Mouydir, Algeria.

deficerus: Nodopericyclus deficerus n. sp.; Mouydir, Algeria.

Separation of the new species. The two species of Nodopericyclus can be separated by means of conch morphology, ornament, and suture line:

- $N$. circumnodosus - at $15 \mathrm{~mm} \mathrm{dm}$ : ww/dm slightly higher than 0.70 , ribs very strong and sharp, external lobe parallel-sided;

- $N$. deficerus - at $15 \mathrm{~mm} \mathrm{dm:} \mathrm{ww/dm} \mathrm{less} \mathrm{than} \mathrm{0.60,} \mathrm{ribs} \mathrm{weak} \mathrm{and} \mathrm{rounded,} \mathrm{external} \mathrm{lobe} \mathrm{V-shaped.}$

Discussion. Nodopericyclus is easily separable from Pericyclus by its strongly bifurcating ribs. A genus with a similar conch ornament is Fascipericyclus Turner, 1948, but this genus shows a modification of the suture line, in which, in the preadult stage, a V-shaped external lobe and a narrowly rounded ventrolateral saddle is present (Tilsley \& Korn 2009).

\section{Nodopericyclus circumnodosus n. sp.}

Figures 21, 22

Derivation of name. From Latin circum $=$ all around and nodosus $=$ nodes, because of the ornamentation

Holotype. Specimen MB.C.19033, illustrated in Figure 21A.

Type locality and horizon. Oued Temertasset, locality and sample MOU-X (Mouydir, South Algeria); Helicocyclus-Ouaoufilalites Assemblage.

Material. Nine specimens, conch diameter up to $23 \mathrm{~mm}$.

Diagnosis. Nodopericyclus with almost stable conch morphology between 9 and $20 \mathrm{~mm} \mathrm{dm}$; conch thinly pachyconic and subevolute; umbilical margin angular, umbilical wall flattened, slightly oblique; aperture low. Steinkern with sharp, slightly biconvex ribs that form prominent umbilical nodes, rib splitting and intercalation frequent near the umbilical margin, rather strong constrictions parallel to the ribs. Suture line with very narrow, parallel-sided or subparallel-sided external lobe and very low median saddle; ventrolateral saddle almost symmetric, broadly rounded; adventive lobe V-shaped, almost symmetric. 

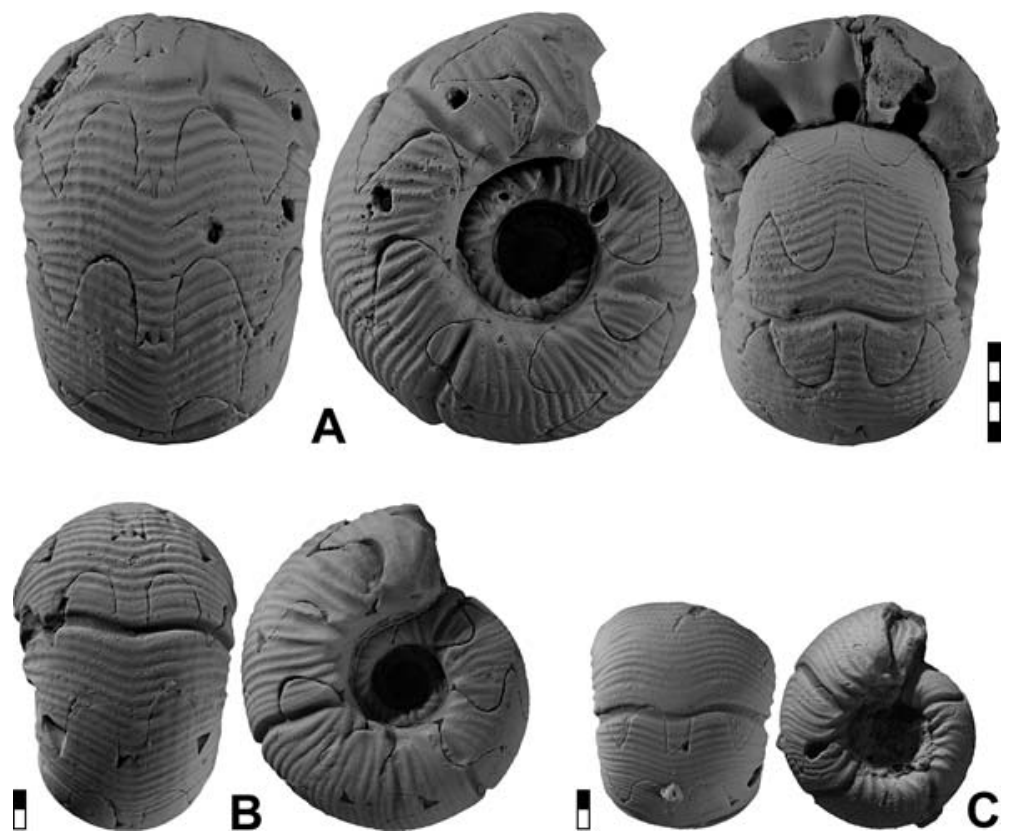

Figure 21. Nodopericyclus circumnodosus $\quad$ n. sp.; all $\times 2$. A. Holotype MB.C.19033 from locality MOU-X. B. Paratype MB.C.18783.1 from locality MOU-B0. C. Paratype MB.C.19043.1 from locality MOU-Y.
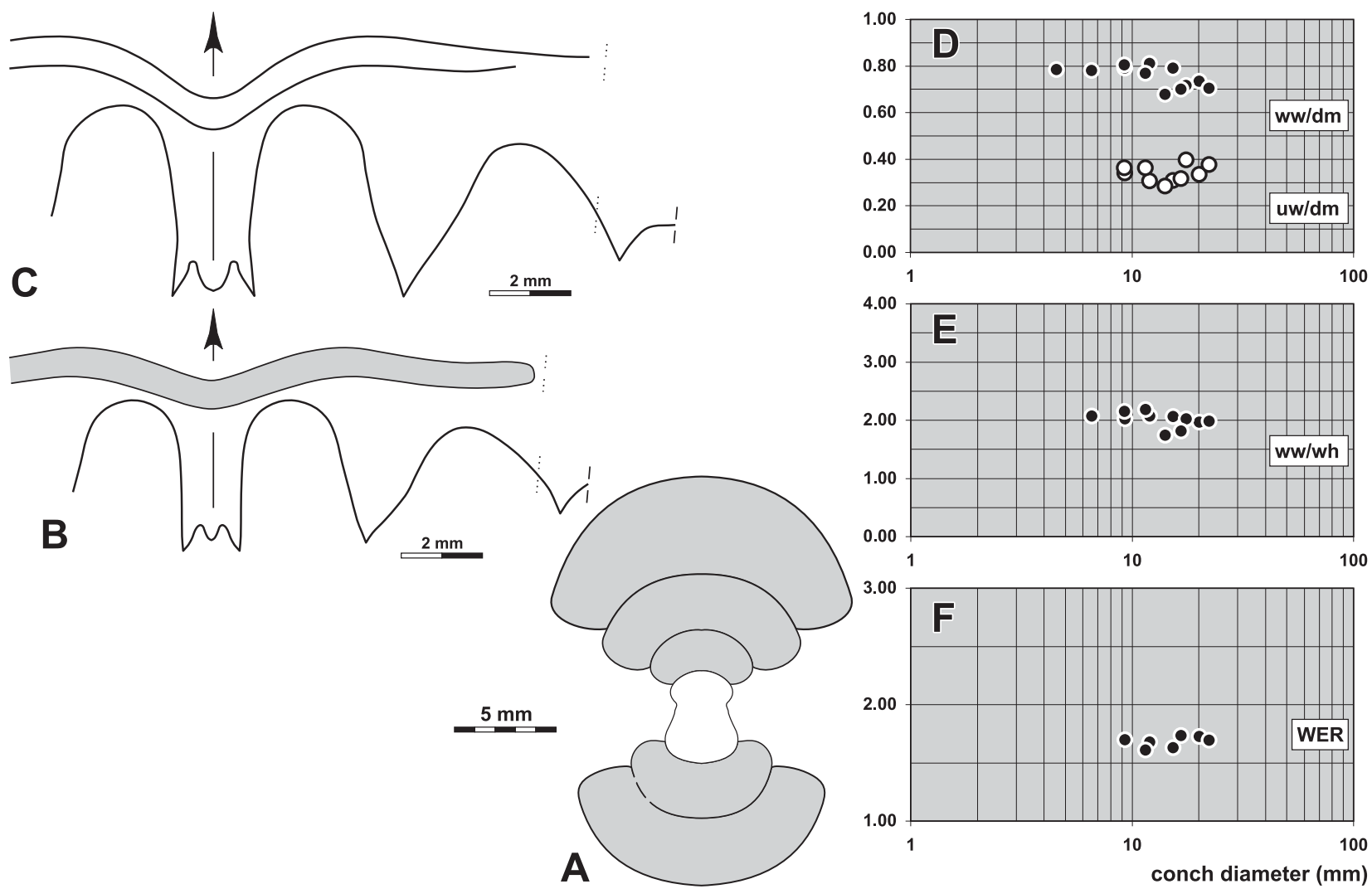

Figure 22. Nodopericyclus circumnodosus n. sp. A. Cross section of paratype MB.C.18783.2 from locality MOU-B0; $\times 2.5$. B. Suture line and constriction of paratype MB.C.18783.1 from locality MOU-B0, at $15.8 \mathrm{~mm} \mathrm{dm}, 10.7 \mathrm{~mm}$ ww, $6.2 \mathrm{~mm}$ wh; $\times 5.0$. C. Suture line and rib course of holotype MB.C.19033 from locality MOU-X, at $19.2 \mathrm{~mm} \mathrm{dm}, 14.2 \mathrm{~mm}$ ww, $7.3 \mathrm{~mm}$ wh; $\times 5.0$. D-F. Ontogenetic development of the conch width index (ww/dm), umbilical width index (uw/dm), whorl width index (ww/wh), and whorl expansion rate (WER) of all available specimens. 
Table 28. Conch ontogeny (Figs 22A, D-F) of Nodopericyclus circumnodosus n. sp.

\begin{tabular}{llll}
\hline $\mathrm{dm}$ & conch shape & whorl cross section shape & aperture \\
\hline $9 \mathrm{~mm}$ & thickly pachyconic; subevolute & strongly depressed; moderately embracing & low \\
& $($ ww/dm $\sim 0.80 ;$ uw/dm $\sim 0.35)$ & $($ ww/wh $\sim 2.10 ;$ IZR $\sim 0.30)$ & $($ WER $=1.70)$ \\
$20 \mathrm{~mm}$ & thinly pachyconic; subevolute & moderately depressed; strongly embracing & low \\
& $($ ww/dm $\sim 0.70 ;$ uw/dm $\sim 0.35)$ & $($ ww/wh $\sim 1.95 ;$ IZR $\sim 0.35)$ & $($ WER $=1.70)$
\end{tabular}

Table 29. Conch dimensions (in $\mathrm{mm}$ ) and proportions for reference specimens of Nodopericyclus circumnodosus $\mathrm{n}$. $\mathrm{sp}$.

\begin{tabular}{|c|c|c|c|c|c|c|c|c|c|c|}
\hline & $\mathrm{dm}$ & $w w$ & wh & uw & ah & $w w / d m$ & ww/wh & $\mathrm{uw} / \mathrm{dm}$ & WER & IZR \\
\hline holotype MB.C.19033 & 22.2 & 15.7 & 7.9 & 8.4 & 5.2 & 0.70 & 1.98 & 0.38 & 1.69 & 0.35 \\
\hline paratype MB.C.18783.2 & 20.1 & 14.8 & 7.5 & 6.7 & 4.8 & 0.73 & 1.97 & 0.33 & 1.73 & 0.36 \\
\hline paratype MB.C.18783.1 & 16.6 & 11.6 & 6.4 & 5.3 & 4.0 & 0.70 & 1.82 & 0.32 & 1.73 & 0.38 \\
\hline paratype MB.C.19043.1 & 11.5 & 8.9 & 4.1 & 4.2 & 2.4 & 0.77 & 2.19 & 0.36 & 1.61 & 0.40 \\
\hline
\end{tabular}

Table 30. Suture line proportions (Figs 22B, C) for Nodopericyclus circumnodosus n. sp.

\begin{tabular}{llllllll}
\hline specimen & at dm & EL w/d & EL/VLS & EL/AL & MS h & VLS w/h & remarks \\
\hline holotype MB.C.19033 & $19.2 \mathrm{~mm}$ & 0.42 & 0.67 & 0.84 & 0.18 & 0.62 & flanks of E lobe slightly incurved \\
paratype MB.C.18783.1 & $15.8 \mathrm{~mm}$ & 0.40 & 0.59 & 0.82 & 0.18 & 0.68 & E lobe almost parallel-sided \\
\hline
\end{tabular}

\section{Nodopericyclus deficerus n. sp.}

Figures 23, 24

Derivation of name. From Latin deficerus = less intensive, because of the weaker ornament.

Holotype. Specimen MB.C.19044.1, illustrated in Figure 23A.

Type locality and horizon. Oued Temertasset, locality and sample MOU-Y (Mouydir, South Algeria); Helicocyclus-Ouaoufilalites Assemblage.

Material. 18 specimens, conch diameter up to $15 \mathrm{~mm}$.

Diagnosis. Nodopericyclus with almost stable conch morphology between 9 and $15 \mathrm{~mm} \mathrm{dm}$; conch thickly discoidal or thinly pachyconic and subevolute; umbilical margin angular, umbilical wall flattened, slightly oblique; aperture low. Steinkern with rounded, slightly biconvex ribs that form weak umbilical nodes, rib splitting and intercalation regular near the umbilical margin, rather strong constrictions parallel to the ribs. Suture line with very narrow, V-shaped external lobe and very low median saddle; ventrolateral saddle almost symmetric, broadly rounded; adventive lobe V-shaped, symmetric.

Table 31. Conch ontogeny (Fig. 24A) of Nodopericyclus deficerus n. sp.

\begin{tabular}{|c|c|c|c|}
\hline$d m$ & conch shape & whorl cross section shape & aperture \\
\hline $9 \mathrm{~mm}$ & $\begin{array}{l}\text { thinly pachyconic; subevolute } \\
\text { (ww/dm } \sim 0.66 ; \text { uw/dm } \sim 0.32 \text { ) }\end{array}$ & $\begin{array}{l}\text { moderately depressed; strongly embracing } \\
\text { (ww/wh } \sim 1.60 ; \text { IZR } \sim 0.42 \text { ) }\end{array}$ & $\begin{array}{l}\text { low } \\
(\text { WER }=1.70)\end{array}$ \\
\hline $15 \mathrm{~mm}$ & $\begin{array}{l}\text { thickly discoidal; subevolute } \\
\text { (ww/dm } \sim 0.57 ; \text { uw/dm } \sim 0.34 \text { ) }\end{array}$ & $\begin{array}{l}\text { moderately depressed; strongly embracing } \\
\text { (ww/wh } \sim 1.50 ; \text { IZR } \sim 0.37 \text { ) }\end{array}$ & $\begin{array}{l}\text { low } \\
(\text { WER }=1.70)\end{array}$ \\
\hline
\end{tabular}

Table 32. Conch dimensions (in $\mathrm{mm}$ ) and proportions for reference specimens of Nodopericyclus deficerus $\mathrm{n}$. sp.

\begin{tabular}{lrrrrrrrrrrr}
\hline & dm & ww & wh & uw & ah & ww/dm & ww/wh & uw/dm & WER & IZR & \\
\hline holotype MB.C.19044.1 & 14.6 & 8.3 & 5.5 & 4.9 & 3.5 & 0.57 & 1.51 & 0.34 & 1.71 & 0.37 \\
paratype MB.C.18995 & 8.9 & 5.9 & 3.7 & 2.8 & 2.1 & 0.66 & 1.61 & 0.32 & 1.72 & 0.42 \\
\hline
\end{tabular}

Table 33. Suture line proportions (Figs 24B) for Nodopericyclus deficerus n. sp.

\begin{tabular}{llllllll}
\hline specimen & at dm & EL w/d & EL/NLS & EL/AL & MS h & VLS w/h & remarks \\
\hline holotype MB.C.19044.1 & c. $12.0 \mathrm{~mm}$ & 0.49 & 0.60 & 0.77 & 0.12 & 0.82 & flanks of E lobe incurved \\
\hline
\end{tabular}




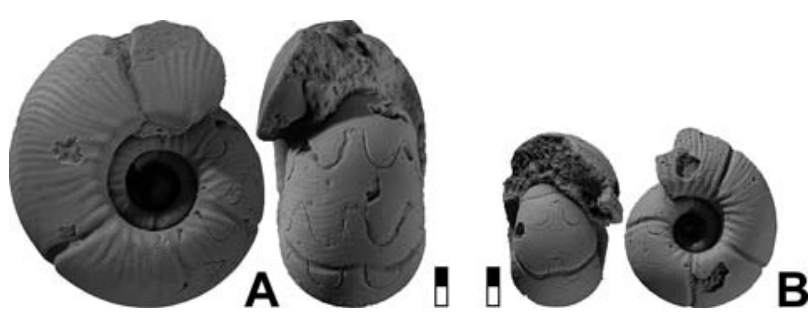

Figure 23. Nodopericyclus deficerus n. sp.; all $\times 2$. A. Holotype MB.C.19044.1 from locality MOU-Y. B. Paratype MB.C.18995 from locality MOU-E13.

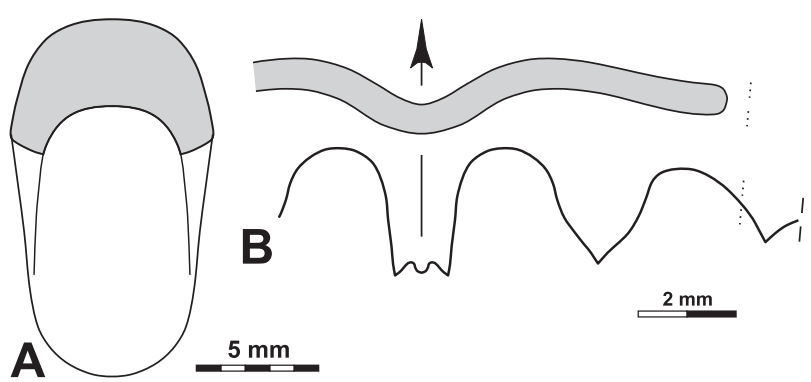

Figure 24. Nodopericyclus deficerus n. sp. from locality MOUY. A. Dorsal view of holotype MB.C. $19044.1 ; \times 2.5$. B. Suture line and constriction of holotype MB.C.19044.1, at $7.5 \mathrm{~mm}$ ww, $4.7 \mathrm{~mm} \mathrm{wh;} \times 5.0$.

Subfamily Ammonellipsitinae Riley, 1996

\section{Ammonellipsites Parkinson, 1822}

For a detailed discussion of the genus, see Ebbighausen et al. (2010).

\section{Ammonellipsites serus n. sp.}

Figures 25, 26

Derivation of name. From Latin serus $=$ late, because of the late presence of ribs.

Holotype. Specimen MB.C.18817.1, illustrated in Figure 25.

Type locality and horizon. Oued Temertasset, locality and sample MOU-C3 (Mouydir, South Algeria); Helicocyclus-Ouaoufilalites Assemblage. Material. Four specimens, conch diameter up to $48 \mathrm{~mm}$.

Diagnosis. Ammonellipsites with a subinvolute conch, changing from thinly pachyconic to thickly discoidal between 20 and $40 \mathrm{~mm} \mathrm{dm}$; aperture moderately high in the middle growth stage and high in the adult stage. Ornament with 50 weak equidistant ribs per volution, course convex and rectiradiate with moderately deep ventral sinus; ribs absent in the stage below $20 \mathrm{~mm} \mathrm{dm}$. Suture line with narrow, V-shaped external lobe with gently sinuous flanks and moderately low median saddle; ventrolateral saddle narrowly rounded, adventive lobe V-shaped, asymmetric with strongly sinuous dorsal flank.

Table 34. Conch ontogeny (Figs 26A, C-E) of Ammonellipsites serus $\mathrm{n}$. sp.

\begin{tabular}{llll}
\hline $\mathrm{dm}$ & conch shape & whorl cross section shape & aperture \\
\hline $20 \mathrm{~mm}$ & thinly pachyconic; subinvolute & weakly depressed; strongly embracing & moderate \\
& $($ ww/dm $\sim 0.64 ;$ uw/dm $\sim 0.22)$ & (ww/wh $\sim 1.00 ;$ IZR $\sim 0.34)$ & $($ WER $\sim 1.95)$ \\
$40 \mathrm{~mm}$ & thickly discoidal; subinvolute & weakly depressed; strongly embracing & high \\
& $($ ww/dm $\sim 0.50 ;$ uw/dm $\sim 0.24)$ & $($ ww/wh $\sim 1.25 ;$ IZR $\sim 0.44)$ & $($ WER $\sim 2.15)$ \\
\hline
\end{tabular}

Table 35. Conch dimensions (in $\mathrm{mm}$ ) and proportions for the holotype of Ammonellipsites serus $\mathrm{n}$. sp.

\begin{tabular}{lccccccccccc}
\hline & $\mathrm{dm}$ & ww & wh & uw & ah & ww/dm & ww/wh & uw/dm & WER & IZR & \\
\hline holotype MB.C.18817.1 & 43.9 & 22.1 & 21.3 & 10.7 & 14.0 & 0.50 & 1.03 & 0.24 & 2.16 & 0.34 \\
dto. & 33.1 & 18.0 & 15.7 & 7.6 & 9.7 & 0.54 & 1.14 & 0.23 & 2.00 & 0.38 \\
dto. & 21.9 & 14.0 & 11.1 & 4.9 & 6.2 & 0.64 & 1.26 & 0.22 & 1.95 & 0.44 \\
\hline
\end{tabular}

Table 36. Suture line proportions (Fig. 26B) for Ammonellipsites serus n. sp.

\begin{tabular}{llllllll}
\hline specimen & at dm & EL w/d & EL/VLS & EL/AL & MS h & VLS w/h & remarks \\
\hline holotype MB.C.18817.1 & $14.0 \mathrm{~mm}$ & 0.66 & 1.21 & 1.16 & 0.36 & 0.54 & A lobe very asymmetric \\
\hline
\end{tabular}

Discussion. Ammonellipsites serus differs from the other species of the genus in the late ontogenetic development of the ribs. The species from the Dalle à Merocanites, for instance, are ribbed already in the juvenile stage (Ebbighausen et al. 2010). 


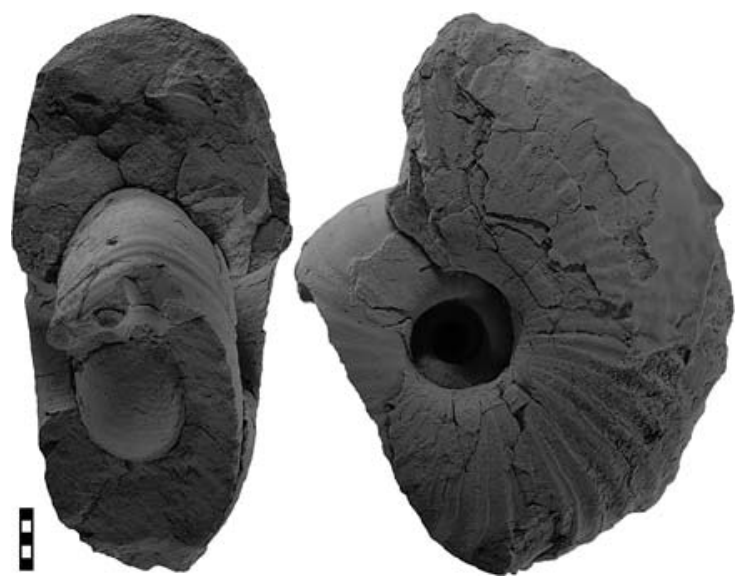

Figure 25. Ammonellipsites serus n. sp. from locality MOU-C3, holotype MB.C.18817.1; × 1.25 .
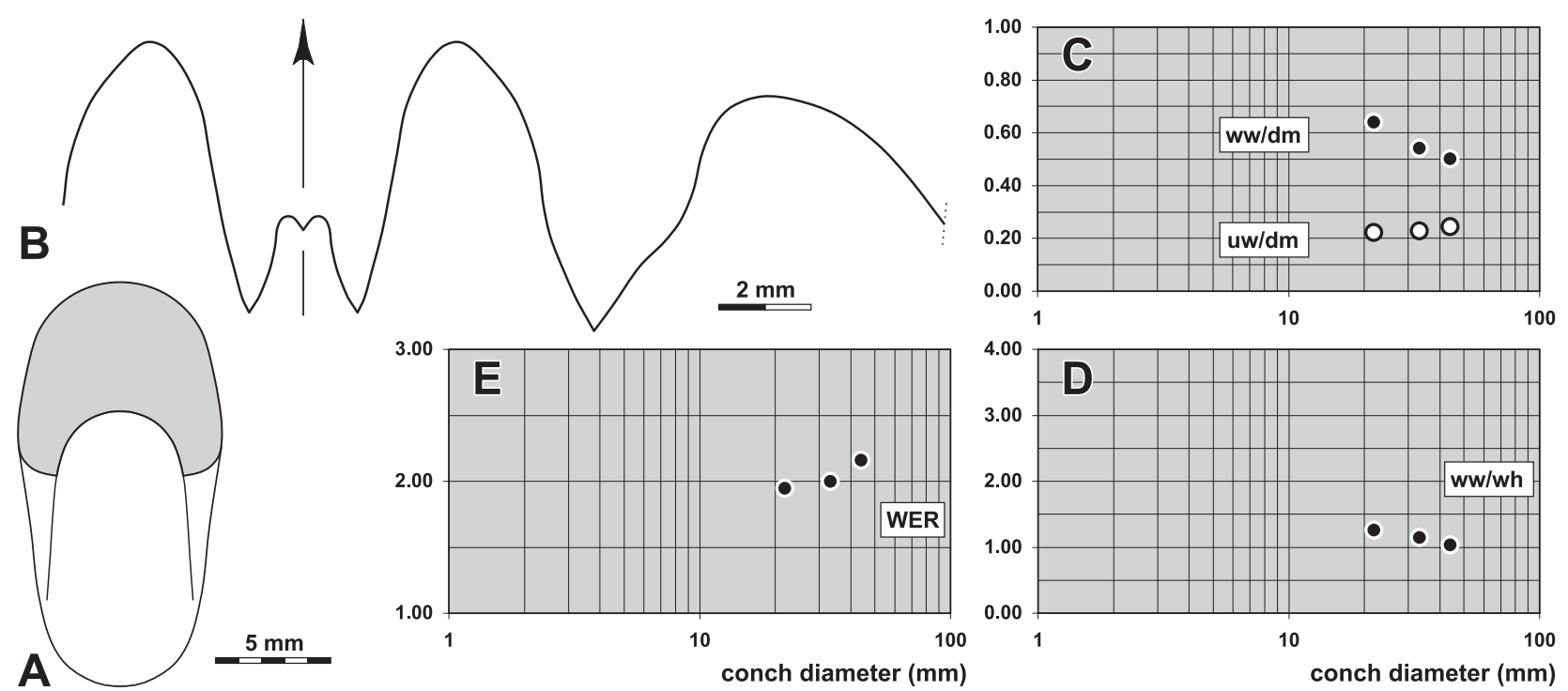

Figure 26. Ammonellipsites serus n. sp. from locality MOU-C3. A. Dorsal view of holotype MB.C.18817.1; $\times 1.0$. B. Suture line of holotype MB.C.18817.1, at $22.2 \mathrm{~mm} \mathrm{dm}, 14.3 \mathrm{~mm}$ ww, $12.5 \mathrm{~mm}$ wh; $\times 5.0$. C-E. Ontogenetic development of the conch width index (ww/dm), umbilical width index (uw/dm), whorl width index (ww/wh), and whorl expansion rate (WER) of the holotype.

\section{Helicocyclus Schindewolf, 1951}

Type species. Pericyclus (Helicocyclus) gracillimus Schindewolf, 1951 [OD].

Genus definition. Pericyclidae with small thinly pachyconic or discoidal conch, reaching up to $50 \mathrm{~mm}$ in diameter. Conch subevolute or evolute with minor ontogenetic changes. Steinkern in some species with moderately coarse, rounded ribs with almost linear course and rectiradiate direction, rib splitting and rib intercalation rare; without or with weak convex or linear constrictions. Suture line with V-shaped, narrow or moderately narrow external lobe $(\mathrm{EL} w / \mathrm{d}=0.55-0.80 ; \mathrm{EL} / \mathrm{AL}=1.00-1.90)$ and low or moderately low median saddle $(\mathrm{MS} \mathrm{h}=0.30-0.40)$; ventrolateral saddle narrowly rounded or subacute; adventive lobe V-shaped and usually asymmetric.

Included species.

aberratus: Helicocyclus aberratus Kusina \& Konovalova, 2004, p. 88; North Urals.

divergens: Helicocyclus divergens Riley, 1996, p. 74; Lancashire.

evolutus: Pericyclus evolutus Librovitch, 1927, p. 28; Tien Shan. [Synonym of H. tianshanicus]

formosus: Helicocyclus formosus n. sp.; Mouydir, Algeria.

fuscus: Helicocyclus fuscus Korn, Bockwinkel, Ebbighausen \& Klug, 2003, p. 84; Anti-Atlas, Morocco.

gracillimus: Pericyclus (Helicocyclus) gracillimus Schindewolf, 1951, p. 79; Harz.

inornatus: Helicocyclus inornatus n. sp.; Mouydir, Algeria.

involutus: Helicocyclus involutus Kusina in Shimansky \& Kusina, 1977, p. 88; North Urals.

laxaris: Helicocyclus laxaris n. sp.; Mouydir, Algeria.

tianshanicus: Pericyclus tianshanicus Librovitch, 1927, p. 29; Tien Shan.

Separation of the new species. The three species of Helicocyclus from Oued Temertasset can be separated by means of conch morphology and the suture line. In the conch proportions and ontogeny, they differ as follows:

- H. formosus and H. inornatus - thickly discoidal and evolute in juveniles, thinly discoidal and subevolute in the adult stage.

- H. laxaris - thinly pachyconic in juveniles, thickly discoidal in the adult stage; subevolute throughout ontogeny. 
The steinkern surface offers more differences:

- H. formosus - 60 moderately coarse, rounded linear ribs with rectiradiate direction; rib splitting is rare; rather deep, almost linear constrictions.

- H. inornatus - without ribs, weak linear constrictions

- H. laxaris - without ribs or constrictions.

Discussion. The suture line shows that Helicocyclus is closely related to the genera Ammonellipsites (which possesses a stouter conch with a narrower umbilicus) and Fascipericyclus (which possesses very coarse bifurcating ribs).

\section{Helicocyclus formosus n. sp.}

Figures 27, 28

Derivation of name. From Latin formosus = beautiful, because of the beautiful ornament.

Holotype. Specimen MB.C.19034.1, illustrated in Figure 27C.

Type locality and horizon. Oued Temertasset, locality and sample MOU-X (Mouydir, South Algeria); Helicocyclus-Ouaoufilalites Assemblage. Material. 16 specimens, conch diameter up to $20 \mathrm{~mm}$.

Diagnosis. Helicocyclus with thickly discoidal and subevolute juvenile conch up to $8 \mathrm{~mm} \mathrm{dm}$, thereafter thinly discoidal and evolute; umbilical wall rounded; aperture low throughout ontogeny. Steinkern with coarse, almost linear constrictions and 60 ribs, rib splitting occurs occasionally. Suture line with narrow external lobe with subparallel flanks; median saddle low; ventrolateral saddle asymmetric, subacute; adventive lobe asymmetric with a stronger curved dorsal flank.

Table 37. Conch ontogeny (Figs 28A, B, D-G) of Helicocyclus formosus n. sp.

\begin{tabular}{|c|c|c|c|}
\hline$d m$ & conch shape & whorl cross section shape & aperture \\
\hline $10 \mathrm{~mm}$ & $\begin{array}{l}\text { thickly discoidal; subevolute } \\
\text { (ww/dm } \sim 0.50 ; \text { uw/dm } \sim 0.42 \text { ) }\end{array}$ & $\begin{array}{l}\text { weakly depressed; strongly embracing } \\
\text { (ww/wh } \sim 1.50 ; \text { IZR } \sim 0.30 \text { ) }\end{array}$ & $\begin{array}{l}\text { low } \\
(\text { WER } \sim 1.60)\end{array}$ \\
\hline $20 \mathrm{~mm}$ & $\begin{array}{l}\text { thinly discoidal; evolute } \\
\text { (ww/dm } \sim 0.45 ; \text { uw/dm } \sim 0.46 \text { ) }\end{array}$ & $\begin{array}{l}\text { weakly depressed; strongly embracing } \\
\text { (ww/wh } \sim 1.50 \text {; IZR } \sim 0.35 \text { ) }\end{array}$ & $\begin{array}{l}\text { low } \\
(\text { WER } \sim 1.55)\end{array}$ \\
\hline
\end{tabular}

Table 38. Conch dimensions (in $\mathrm{mm}$ ) and proportions for reference specimens of Helicocyclus formosus $\mathrm{n}$. sp.

\begin{tabular}{|c|c|c|c|c|c|c|c|c|c|c|}
\hline & $\mathrm{dm}$ & ww & wh & uw & ah & ww/dm & ww/wh & $\mathrm{uw} / \mathrm{dm}$ & WER & IZR \\
\hline paratype MB.C.188746 & 19.9 & - & 6.0 & 9.1 & 3.9 & - & - & 0.46 & 1.54 & 0.35 \\
\hline paratype MB.C.19034.2 & 15.3 & 7.0 & 4.7 & 6.9 & 3.0 & 0.46 & 1.50 & 0.45 & 1.56 & 0.35 \\
\hline holotype MB.C.19034.1 & 14.6 & 7.2 & 4.8 & 6.2 & 2.8 & 0.49 & 1.50 & 0.42 & 1.53 & 0.41 \\
\hline paratype MB.C.18988.1 & 13.6 & 6.2 & 4.2 & 5.6 & 2.7 & 0.45 & 1.48 & 0.41 & 1.55 & 0.36 \\
\hline
\end{tabular}

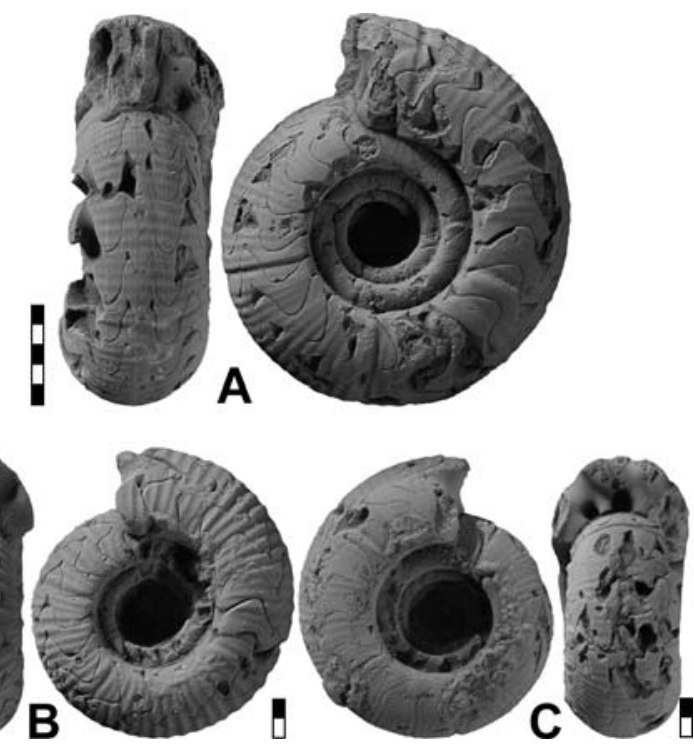

Figure 27. Helicocyclus formosus n. sp.; all $\times 2$. A. Paratype MB.C.188746 from locality A321. B. Paratype MB.C.19034.2 from locality MOU-X. C. Holotype MB.C.19034.1 from locality MOU-X. 
Table 39. Suture line proportions (Fig. 28C) for Helicocyclus formosus n. sp.

\begin{tabular}{llllllll}
\hline specimen & at dm & EL w/d & EL/NLS & EL/AL & MS h & VLS w/h & remarks \\
\hline holotype MB.C.19034.1 & $14.0 \mathrm{~mm}$ & 0.55 & 1.06 & 1.27 & 0.40 & 0.52 & VL saddle subacute \\
\hline
\end{tabular}

Discussion. Helicocyclus formosus shows some resemblance to H. tianshanicus, but that species shows much weaker and more numerous ribs.
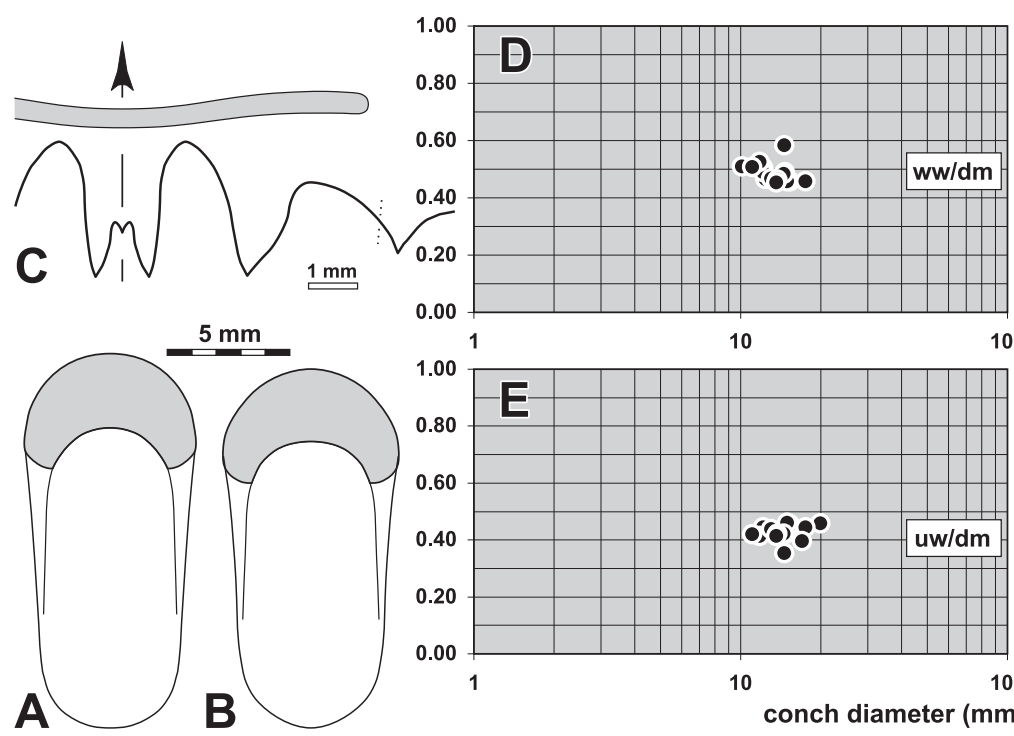

10

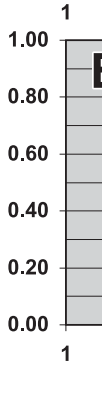

100

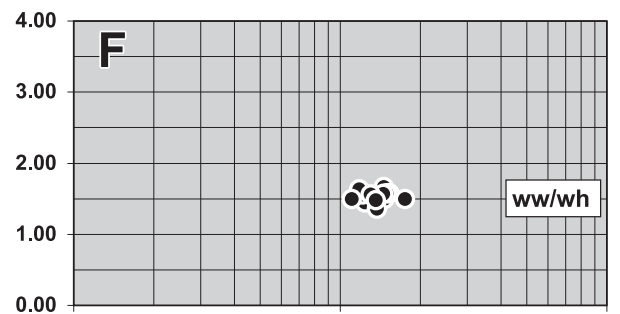

10 100

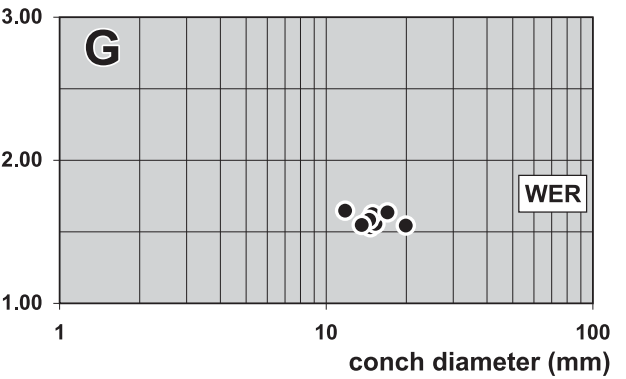

Figure 28. Helicocyclus formosus n. sp. A. Dorsal view of paratype MB.C.19034.2 from locality MOU-X; $\times 2.5$. B. Dorsal view of holotype MB.C.19034.1 from locality MOU-X; $\times 2.5$. C. Suture line and constriction of holotype MB.C.19034.1 from locality MOU-X, at $14.0 \mathrm{~mm} \mathrm{dm}, 7.3 \mathrm{~mm}$ ww, $5.0 \mathrm{~mm} \mathrm{wh} \times 5.0$. D-G. Ontogenetic development of the conch width index (ww/dm), umbilical width index (uw/dm), whorl width index (ww/wh), and whorl expansion rate (WER) of all available specimens.

\section{Helicocyclus inornatus $\mathbf{n}$. sp.}

Figures 29, 30

Derivation of name. From Latin inornatus = undecorated, because of the weak ornament.

Holotype. Specimen MB.C.19035.1, illustrated in Figure 29A.

Type locality and horizon. Oued Temertasset, locality and sample MOU-X (Mouydir, South Algeria); Helicocyclus-Ouaoufilalites Assemblage. Material. 108 specimens, conch diameter up to $14 \mathrm{~mm}$.

Diagnosis. Helicocyclus with thickly discoidal and evolute juvenile conch up to $8 \mathrm{~mm} \mathrm{dm}$, thereafter thinly discoidal and subevolute; umbilical wall rounded; aperture low throughout ontogeny. Steinkern with weak, almost linear constrictions, without ribs. Suture line with moderately narrow V-shaped external lobe with almost straight flanks; median saddle low; ventrolateral saddle symmetric, narrowly rounded; adventive lobe asymmetric with a stronger curved dorsal flank.

Table 40. Conch ontogeny (Figs 30A, B, D-G) of Helicocyclus inornatus n. sp.

\begin{tabular}{llll}
\hline $\mathrm{dm}$ & conch shape & whorl cross section shape & aperture \\
\hline $2 \mathrm{~mm}$ & thickly discoidal; evolute & moderately depressed; moderately embracing & low \\
& $($ ww/dm $\sim 0.50 ;$ uw/dm $\sim 0.50)$ & (ww/wh $\sim 1.70 ;$ IZR $\sim 0.20)$ & $($ WER $\sim 1.70)$ \\
$8 \mathrm{~mm}$ & thinly to thickly discoidal; subevolute & weakly depressed; strongly embracing & low \\
& $($ ww/dm $=0.42-0.50 ;$ uw/dm $=0.36-0.43)$ & $($ ww/wh $=1.25-1.40 ;$ IZR $\sim 0.33)$ & $($ WER $\sim 1.70)$ \\
$13 \mathrm{~mm}$ & thinly discoidal; subevolute & weakly depressed; strongly embracing & low \\
& $($ ww/dm $\sim 0.42 ;$ uw/dm $=0.40-0.45)$ & $($ ww/wh $=1.25-1.40 ;$ IZR $\sim 0.33)$ & (WER $\sim 1.60)$ \\
\hline
\end{tabular}


Table 41. Conch dimensions (in $\mathrm{mm}$ ) and proportions for reference specimens of Helicocyclus inornatus $\mathrm{n}$. $\mathrm{sp}$.

\begin{tabular}{lrllllllllll}
\hline & $\mathrm{dm}$ & ww & wh & uw & ah & ww/dm & ww/wh & uw/dm & WER & IZR \\
\hline paratype MB.C.19035.4 & 13.1 & 5.2 & 4.1 & 5.5 & 2.8 & 0.40 & 1.27 & 0.42 & 1.62 & 0.33 \\
holotype MB.C.19035.1 & 11.4 & 4.5 & 3.7 & 4.7 & 2.5 & 0.40 & 1.21 & 0.41 & 1.63 & 0.34 \\
paratype MB.C.19035.3 & 11.2 & 5.2 & 3.8 & 4.1 & 2.4 & 0.47 & 1.37 & 0.37 & 1.64 & 0.36 \\
paratype MB.C.19035.2 & 9.7 & 4.0 & 3.1 & 4.0 & 2.0 & 0.41 & 1.27 & 0.41 & 1.60 & 0.34 \\
\hline
\end{tabular}

Table 42. Suture line proportions (Fig. 30C) for Helicocyclus inornatus n. sp.

\begin{tabular}{llllllll}
\hline specimen & at dm & EL w/d & EL/VLS & EL/AL & MS h & VLS w/h & remarks \\
\hline holotype MB.C.19035.1 & $11.1 \mathrm{~mm}$ & 0.78 & 1.51 & 1.87 & 0.34 & 0.52 & E lobe considerably wide \\
\hline
\end{tabular}

Discussion. Helicocyclus inornatus belongs to the species within the genus without ribs. It is similar to H.fuscus, but that species has stronger, forwardly directed constrictions. H. laxaris has a stouter, narrower umbilicate conch.

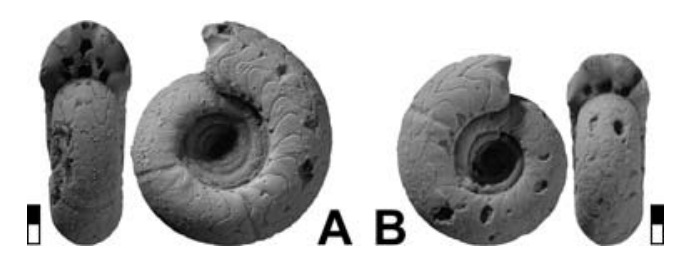

$C \ln _{1}^{1}$
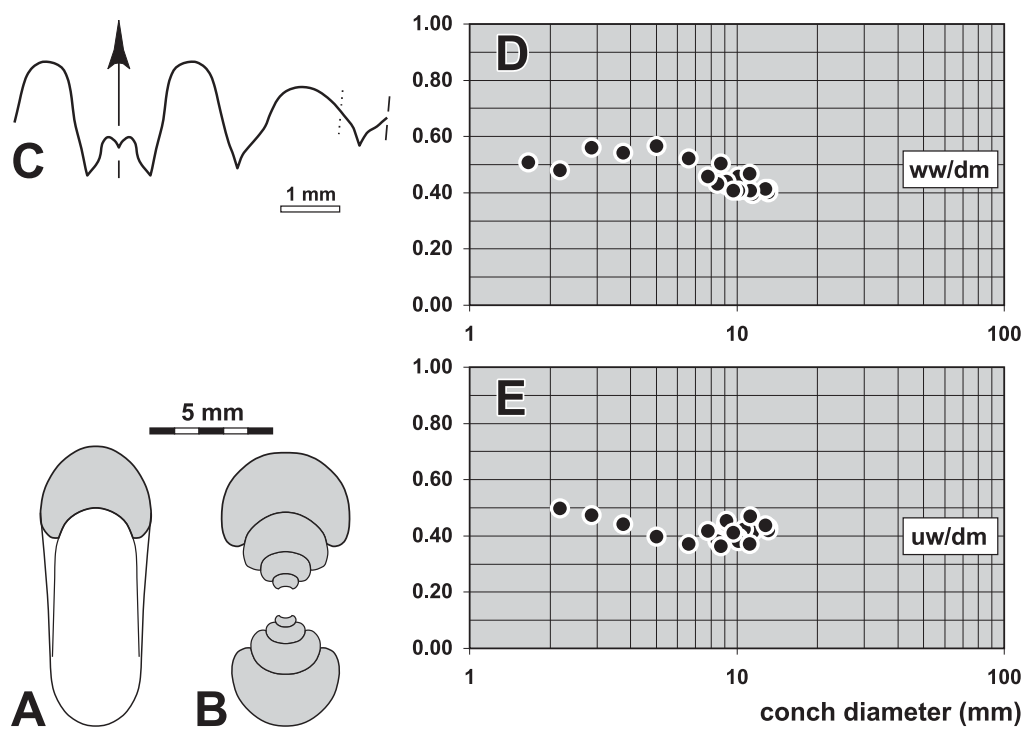

Figure 29. Helicocyclus inornatus n. sp. from locality MOU-X; all $\times 2$. A Holotype MB.C.19035.1. B. Paratype MB.C.19035.2.

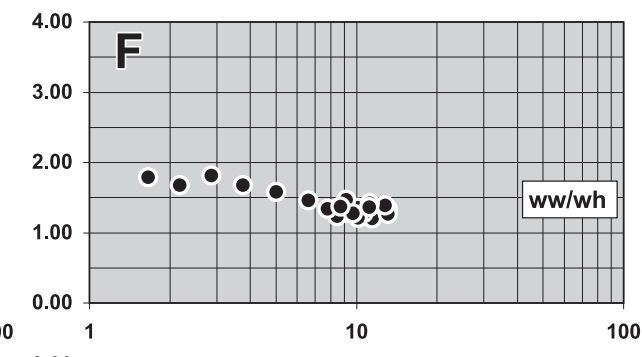

Figure 30. Helicocyclus inornatus n. sp. from locality MOU-X. A. Dorsal view of holotype MB.C.19035.1; $\times 2.5$. B. Cross section of paratype MB.C.19035.3; $\times 2.5$. C. Suture line of holotype MB.C.19035.1, at $11.1 \mathrm{~mm} \mathrm{dm,} 4.6 \mathrm{~mm}$ ww, $3.8 \mathrm{~mm}$ wh; $\times 6.0$. DG. Ontogenetic development of the conch width index (ww/dm), umbilical width index (uw/dm), whorl width index (ww/wh), and whorl expansion rate (WER) of all available specimens.

\section{Helicocyclus laxaris n. sp.}

Figures 31, 32

Derivation of name. From Latin laxaris = widened, because of the rather stout conch.

Holotype. Specimen MB.C.19036.1, illustrated in Figure 31A.

Type locality and horizon. Oued Temertasset, locality and sample MOU-X (Mouydir, South Algeria); Helicocyclus-Ouaoufilalites Assemblage. Material. 22 specimens, conch diameter up to $13 \mathrm{~mm}$.

Diagnosis. Helicocyclus with thinly pachyconic and subevolute juvenile conch up to $8 \mathrm{~mm}$ dm, thereafter thickly discoidal and subevolute; umbilical wall rounded; aperture low throughout ontogeny. Steinkern without constrictions or ribs. Suture line with narrow V-shaped external lobe with gently curved flanks; median saddle low; ventrolateral saddle symmetric, narrowly rounded; adventive lobe almost symmetric. 
Table 43. Conch ontogeny (Figs 32A, B, D-G) of Helicocyclus laxaris n. sp.

\begin{tabular}{llll}
\hline $\mathrm{dm}$ & conch shape & whorl cross section shape & aperture \\
\hline $2 \mathrm{~mm}$ & thickly discoidal; subevolute & moderately depressed; moderately embracing & low \\
& $($ ww/dm $\sim 0.57 ;$ uw/dm $\sim 0.38)$ & $($ ww/wh $\sim 1.75 ;$ IZR $\sim 0.28)$ & (WER $\sim 1.70)$ \\
$8 \mathrm{~mm}$ & thickly discoidal to thinly pachyconic; subevolute & moderately depressed; strongly embracing & low \\
& $($ ww/dm $=0.55-0.63 ;$ uw/dm $=0.30-0.38)$ & $($ ww/wh $=1.50-1.75 ;$ IZR $\sim 0.35)$ & $($ WER $=1.55-1.75)$ \\
$13 \mathrm{~mm}$ & thickly discoidal; subevolute & moderately depressed; strongly embracing & low \\
& $($ ww/dm $\sim 0.55 ;$ uw/dm $\sim 0.35)$ & $($ ww/wh $\sim 1.50 ;$ IZR $\sim 0.42)$ & (WER $\sim 1.60)$ \\
\hline
\end{tabular}

Table 44. Conch dimensions (in $\mathrm{mm}$ ) and proportions for reference specimens of Helicocyclus laxaris $\mathrm{n}$. $\mathrm{sp}$.

\begin{tabular}{lrrrrrrrrrr}
\hline & dm & ww & wh & uw & ah & ww/dm & ww/wh & uw/dm & WER & IZR \\
\hline paratype MB.C.19036.3 & 12.9 & 7.0 & 4.6 & 4.6 & 2.7 & 0.55 & 1.52 & 0.35 & 1.60 & 0.42 \\
paratype MB.C.18844 & 11.3 & 5.6 & 3.7 & 4.3 & 2.4 & 0.50 & 1.49 & 0.38 & 1.62 & 0.36 \\
holotype MB.C.19036.1 & 9.7 & 5.4 & 3.5 & 3.3 & 2.0 & 0.55 & 1.53 & 0.34 & 1.58 & 0.43 \\
paratype MB.C.19036.2 & 9.1 & 5.1 & 3.1 & 3.2 & 2.1 & 0.56 & 1.61 & 0.35 & 1.67 & 0.35 \\
\hline
\end{tabular}

Table 45. Suture line proportions (Fig. 32C) for Helicocyclus laxaris n. sp.

\begin{tabular}{llllllll}
\hline specimen & at dm & EL w/d & EL/NLS & EL/AL & MS h & VLS w/h & remarks \\
\hline holotype MB.C.19036.1 & $9.4 \mathrm{~mm}$ & 0.63 & 1.29 & 1.02 & 0.34 & 0.49 & A lobe deeper than E lobe \\
\hline
\end{tabular}

Discussion. The new species has a much stouter conch than Helicocyclus laxaris and H. fuscus and is therefore easily separated.
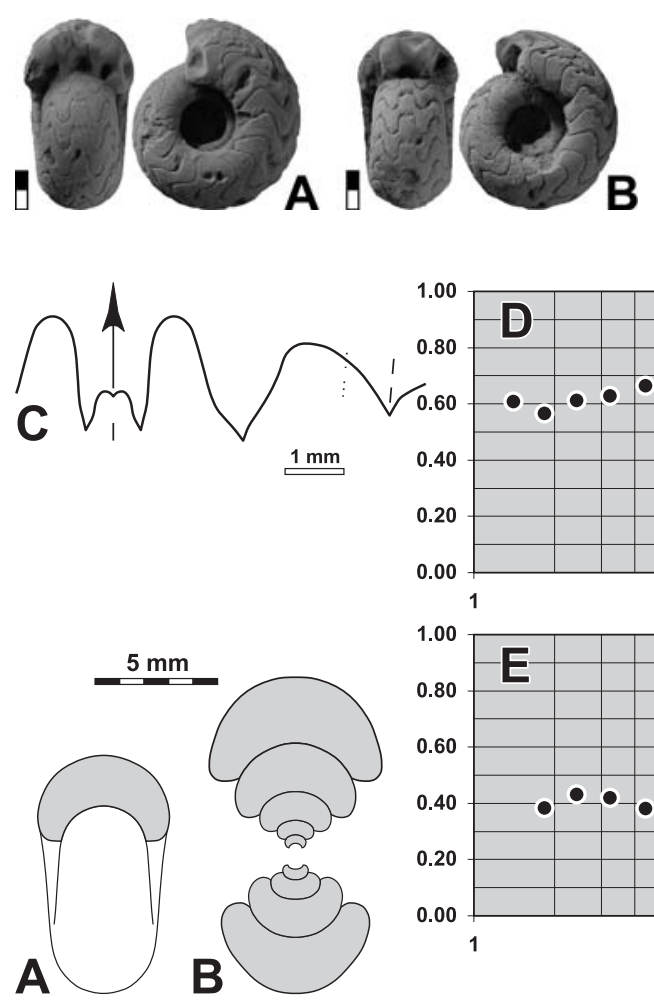

Figure 31. Helicocyclus laxaris $\mathrm{n}$. sp. from locality MOU-X; all $\times 2$. A. Holotype MB.C.19036.1. B. Paratype MB.C.19036.2.

Figure 32. Helicocyclus laxaris n. sp. from locality MOU-X. A. Dorsal view of holotype MB.C.19036.1; $\times 2.5$. B. Cross section of paratype MB.C.19036.3; $\times 2.5$. C. Suture line of holotype MB.C.19036.1, at $9.4 \mathrm{~mm} \mathrm{dm}, 5.4 \mathrm{~mm} w w, 4.3 \mathrm{~mm}$ wh; $\times 6.0$. DG. Ontogenetic development of the conch width index (ww/dm), umbilical width index (uw/dm), whorl width index (ww/wh), and whorl expansion rate (WER) of all available specimens. 


\section{Ouaoufilalites Korn, Bockwinkel, Ebbighausen \& Klug, 2003}

Type species. Ouaoufilalites ouaoufilalensis Korn, Bockwinkel, Ebbighausen \& Klug, 2003 (OD)

Genus definition. Ammonellipsitinae with a small conch, reaching approximately $50 \mathrm{~mm}$ conch diameter; conch ontogeny complex; shape thickly pachyconic in juveniles and thinly pachyconic in the adult stage; juvenile stage subevolute, intermediate stage with closure of the umbilicus, adult stage again subevolute. Ornament almost smooth or with convex riblets. Suture line with V-shaped, very narrow or narrow external lobe $(\mathrm{EL} \mathrm{w} / \mathrm{d}=0.45-0.65 ; \mathrm{EL} / \mathrm{AL}=0.90-1.20)$ with slightly diverging flanks; median saddle low $(\mathrm{MS} \mathrm{h}=0.25-0.35)$; ventrolateral saddle broadly rounded; adventive lobe deeper than external lobe, V-shaped.

Included species.

creber: Ouaoufilalites creber n. sp.; Mouydir, Algeria.

ouaoufilalensis: Ouaoufilalites ouaoufilalensis Korn, Bockwinkel, Ebbighausen \& Klug, 2003, p. 84; Anti-Atlas, Morocco.

Discussion. Ouaoufilalites was attributed by Korn et al. (2003) to the family Maxigoniatitidae. However, the shape of the external lobe (V-shaped with slightly sinuous flanks) and the ventrolateral saddle (narrowly rounded at the top) as well as the presence of ribs in the new material suggests that the genus belongs to the ammonellipsitin ammonoids.

\section{Ouaoufilalites creber n. sp.}

Figures 33, 34

Derivation of name. From Latin creber $=$ condensed, because of the crowded septa.

Holotype. Specimen MB.C.18733.1, illustrated in Figure 33C.

Type locality and horizon. Oued Temertasset, locality and sample A320-5 (Mouydir, South Algeria); Helicocyclus-Ouaoufilalites Assemblage.

Material. 55 specimens, conch diameter up to $26 \mathrm{~mm}$.

Diagnosis. Ouaoufilalites with thickly pachyconic conch up to $12 \mathrm{~mm} \mathrm{dm}$, thereafter becoming thinly pachyconic at $20 \mathrm{~mm}$ dm; conch subevolute in the early juvenile stage (up to $2 \mathrm{~mm} \mathrm{dm}$ ), subinvolute in an intermediate growth interval (2-18 $\mathrm{mm} \mathrm{dm}$ ), and subevolute in the adult stage; umbilical margin, flanks and venter broadly rounded. Ornament with 50 weak, shallow ribs; rib course slightly convex with wide and shallow ventral sinus. Steinkern with weak or without constrictions. Suture line with V-shaped, very narrow or narrow external lobe; median saddle low; ventrolateral saddle narrowly rounded; adventive lobe deep, V-shaped.

Discussion. Ouaoufilalites creber differs from O. ouaoufilalensis in the stouter conch at comparable sizes (ww/ $\mathrm{dm}=0.66$ in $O$. ouaoufilalensis but 0.75 in O. creber at $13 \mathrm{~mm} \mathrm{dm}$ ). The steinkern of $O$. ouaoufilalensis has weak constrictions, which cannot be seen in $O$. creber. Instead, O. creber possesses weak riblets, which are absent in O. ouaoufilalensis.
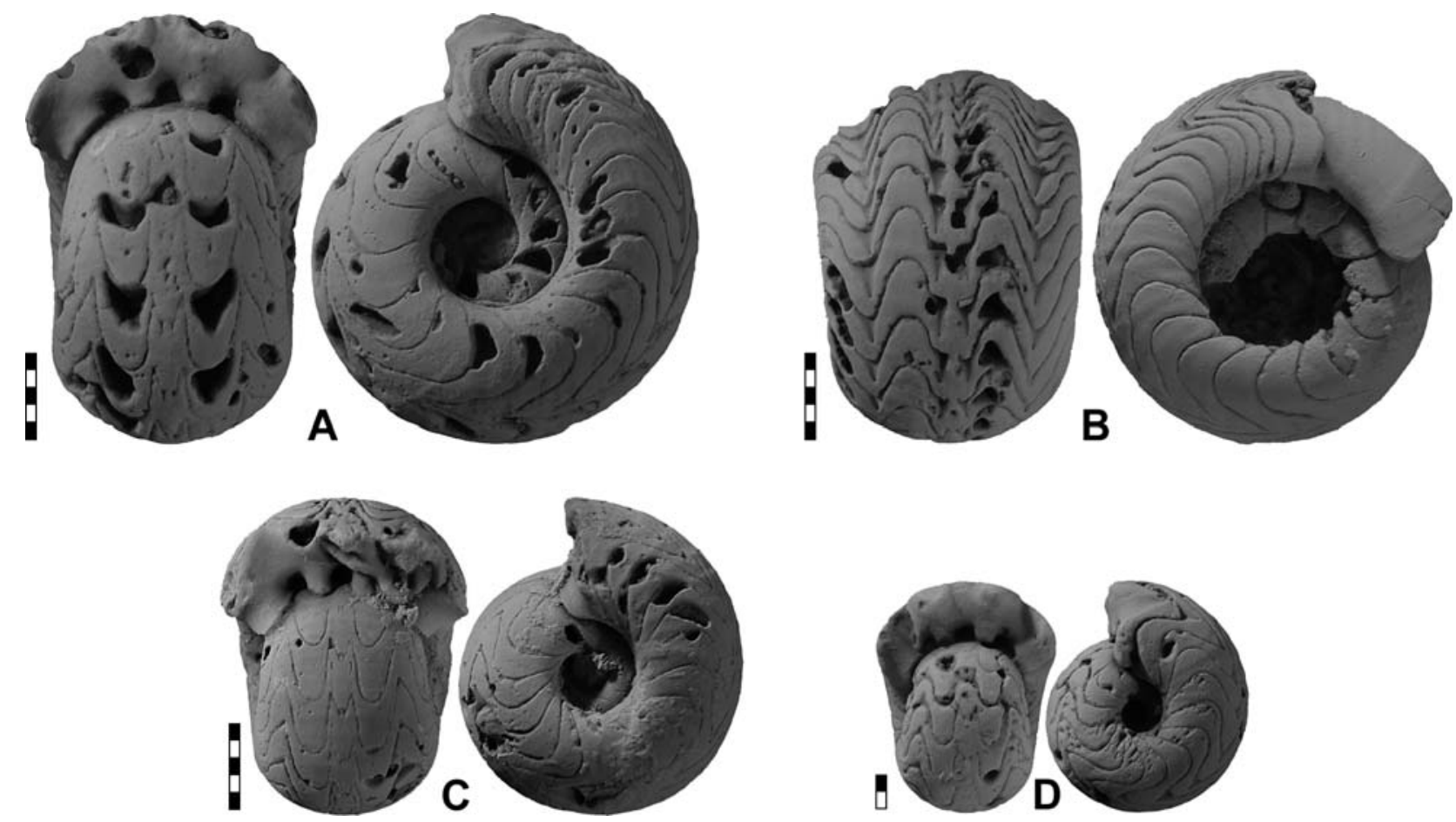

Figure 33. Ouaoufilalites creber n. sp. from locality A320-5; all $\times 2$. A. Paratype MB.C.18733.2. B. Paratype MB.C.18733.3. C. Holotype MB.C.18733.1. D. Paratype MB.C.18733.4. 

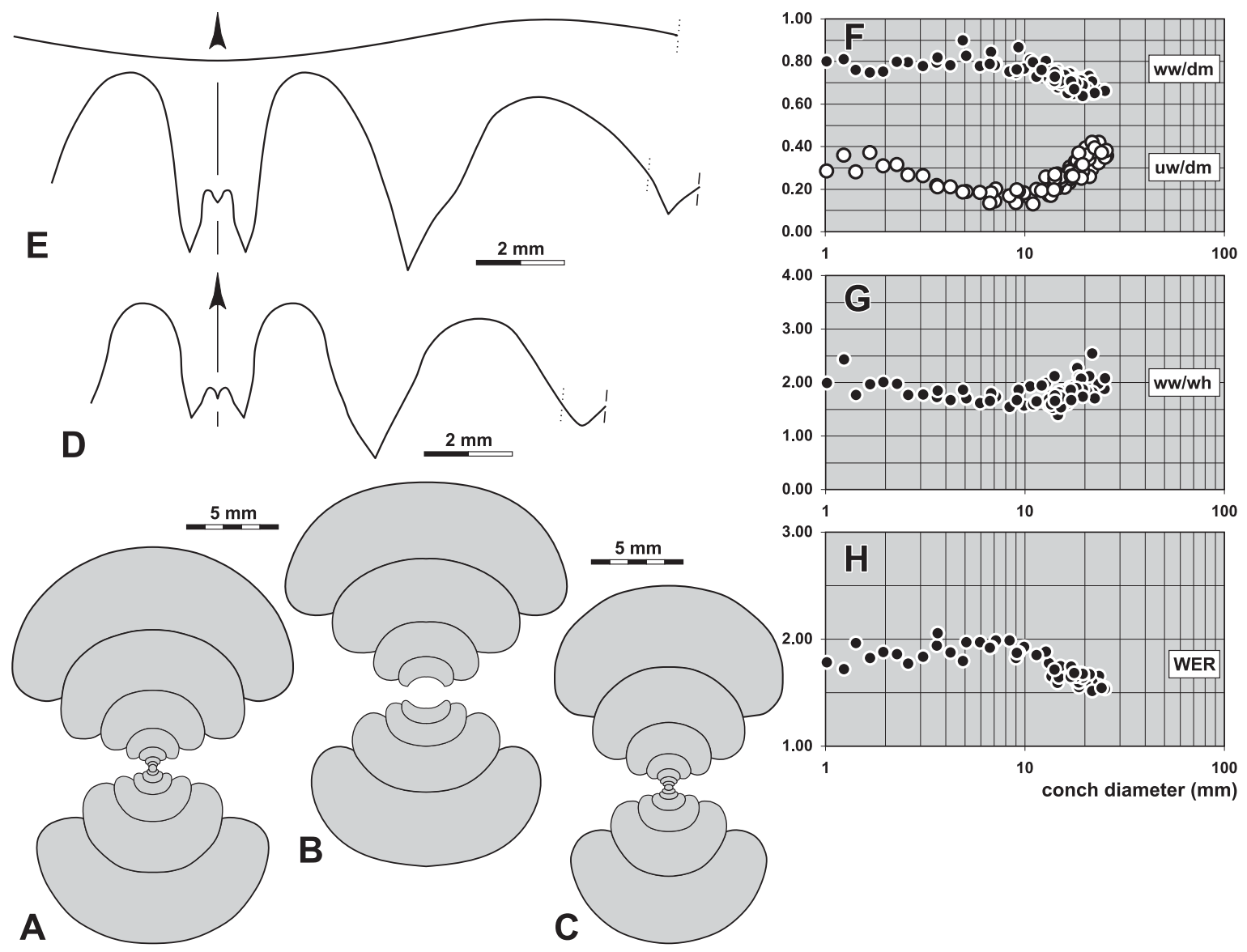

Figure 34. Ouaoufilalites creber n. sp. A. Cross section of paratype MB.C.18733.5 from locality A320-5; $\times 2.5$. B. Cross section of paratype MB.C.18733.6 from locality A320-5; $\times 2.5$. C. Cross section of paratype MB.C.19070.1 from an unrecorded locality; $\times 2.5$. D. Suture line of paratype MB.C. 18733.4 from locality A320 -5 , at $12.8 \mathrm{~mm} \mathrm{dm}, 10.1 \mathrm{~mm} w w, 5.9 \mathrm{~mm}$ wh; $\times 6.0$. E. Suture line and rib course of holotype MB.C.18733.1 from locality A320-5, at $18.2 \mathrm{~mm} \mathrm{dm}, 13.6 \mathrm{~mm}$ ww, $7.1 \mathrm{~mm}$ wh; $\times 6.0$. F-H. Ontogenetic development of the conch width index (ww/dm), umbilical width index (uw/dm), whorl width index (ww/wh), and whorl expansion rate (WER) of all available specimens.

Table 46. Conch ontogeny (Figs 34A-C, F-H) of Ouaoufilalites creber n. sp.

\begin{tabular}{|c|c|c|c|}
\hline $\mathrm{dm}$ & conch shape & whorl cross section shape & aperture \\
\hline $2 \mathrm{~mm}$ & $\begin{array}{l}\text { thickly pachyconic; subevolute } \\
(\mathrm{ww} / \mathrm{dm}=0.75-0.80 ; \mathrm{uw} / \mathrm{dm}=0.30-0.35)\end{array}$ & $\begin{array}{l}\text { moderately depressed; strongly embracing } \\
\text { ( } w w / w h=1.90-2.00 ; \text { IZR } \sim 0.30 \text { ) }\end{array}$ & $\begin{array}{l}\text { moderate } \\
(\text { WER } \sim 1.85)\end{array}$ \\
\hline $8 \mathrm{~mm}$ & $\begin{array}{l}\text { thickly pachyconic; subinvolute } \\
(\mathrm{ww} / \mathrm{dm}=0.75-0.85 ; \mathrm{uw} / \mathrm{dm}=0.15-0.20)\end{array}$ & $\begin{array}{l}\text { moderately depressed; strongly embracing } \\
(\mathrm{ww} / \mathrm{wh}=1.50-1.90 ; \mathrm{IZR}=0.40-0.45)\end{array}$ & $\begin{array}{l}\text { moderate } \\
(\text { WER } \sim 1.95)\end{array}$ \\
\hline $20 \mathrm{~mm}$ & $\begin{array}{l}\text { thinly pachyconic; subinvolute to subevolute } \\
(\mathrm{ww} / \mathrm{dm}=0.64-0.72 ; \mathrm{uw} / \mathrm{dm}=0.25-0.40)\end{array}$ & $\begin{array}{l}\text { moderately to strongly depressed; strongly embracing } \\
(\mathrm{ww} / \mathrm{wh}=1.75-2.25 ; \mathrm{IZR}=0.30-0.45)\end{array}$ & $\begin{array}{l}\text { low } \\
(\text { WER }=1.55-1.70)\end{array}$ \\
\hline $25 \mathrm{~mm}$ & $\begin{array}{l}\text { thinly pachyconic; subevolute } \\
(\mathrm{ww} / \mathrm{dm} \sim 0.65 ; \mathrm{uw} / \mathrm{dm}=0.35-0.42)\end{array}$ & $\begin{array}{l}\text { moderately to strongly depressed; strongly embracing } \\
(\mathrm{w} w / w h=1.85-2.25 ; \mathrm{IZR}=0.40-0.45)\end{array}$ & $\begin{array}{l}\text { low } \\
\text { (WER 1.55) }\end{array}$ \\
\hline
\end{tabular}

Table 47. Conch dimensions (in $\mathrm{mm}$ ) and proportions for reference specimens of Ouaoufilalites creber $\mathrm{n}$. sp.

\begin{tabular}{lcccccccccc}
\hline & dm & ww & wh & uw & ah & ww/dm & ww/wh & uw/dm & WER & IZR \\
\hline paratype MB.C.18733.2 & 25.0 & 16.7 & 8.9 & 9.0 & 4.9 & 0.67 & 1.88 & 0.36 & 1.55 & 0.45 \\
paratype MB.C.18733.7 & 23.4 & 15.7 & 7.9 & 7.6 & 4.7 & 0.67 & 1.98 & 0.32 & 1.57 & 0.40 \\
paratype MB.C.18733.3 & 21.8 & 15.4 & 7.2 & 9.2 & 4.1 & 0.71 & 2.13 & 0.42 & 1.51 & 0.44 \\
holotype MB.C.18733.1 & 18.6 & 13.4 & 6.4 & 5.5 & 3.7 & 0.72 & 2.10 & 0.30 & 1.55 & 0.42 \\
paratype MB.C.18733.4 & 13.6 & 10.1 & 5.7 & 2.9 & 3.0 & 0.74 & 1.77 & 0.21 & 1.65 & 0.47 \\
paratype MB.C.18733.8 & 9.0 & 6.7 & 4.1 & 1.2 & 2.3 & 0.75 & 1.64 & 0.14 & 1.82 & 0.43 \\
\hline
\end{tabular}


Table 48. Suture line proportions (Figs 34D, E) for Ouaoufilalites creber n. sp.

\begin{tabular}{llllllll}
\hline specimen & at dm & EL w/d & EL/VLS & EL/AL & MS h & VLS w/h remarks \\
\hline holotype MB.C.18733.1 & $18.2 \mathrm{~mm}$ & 0.49 & 0.76 & 1.01 & 0.35 & 0.64 & \\
paratype MB.C.18733.4 & $12.8 \mathrm{~mm}$ & 0.63 & 0.95 & 0.90 & 0.26 & 0.66 & A lobe much deeper than E lobe \\
\hline
\end{tabular}

Family Temertassetiidae n. fam.

Family definition. Pericyclid ammonoids with usually thickly discoidal or thinly pachyconic, involute to subevolute conch, rarely discoidal. Umbilical margin often angular; aperture moderately high or high. Steinkern often with strong constrictions, weak ribs in some species. Suture line with Vshaped external lobe with slightly sinuous flanks; prongs of the external lobe often hook-shaped; median saddle very low to moderately low.

Included genera.

Temertassetia $\mathrm{n}$. gen.

Jerania $\mathrm{n}$. gen.

Kusinia n. gen.

Bouhamedites Korn, Bockwinkel, Ebbighausen \& Klug, 2003.

Discussion. The new family differs from the families Pericyclidae and Muensteroceratidae mainly in the suture line, which possesses flexed flanks of the external lobe. Such a shape of the external lobe is also known from the stratigraphically younger subfamilies Maxigoniatitinae Korn, Klug \& Mapes, 1999 and Bollanditinae Bockwinkel, Korn \& Ebbighausen, 2010. The members of these two subfamilies, however, differ strikingly in their conch ontogeny with a prolongued evolute juvenile stage and their much weaker ornament. The shape of the external lobe is therefore treated as homoplastic character.

\section{Temertassetia n. gen.}

Derivation of name. After Oued Temertasset in the Mouydir.

Type species. Temertassetia temertassetensis n. sp.

Genus definition. Temertassetiidae with rather small conch, reaching a maximum conch diameter of 50 mm. Conch subinvolute or subevolute, narrowing of the umbilicus in juvenile stages, some species with adult re-opening of the umbilicus. Steinkern with prominent concavo-convex or biconvex constrictions; faint or sharp riblets between the steinkern constrictions. Suture line with V-shaped, very narrow or narrow external lobe $(E L$ w/d $=0.40-0.70 ; E L / A L=0.90-1.40)$ and very low or low median saddle $(\mathrm{MS} h=0.18-0.25)$; ventrolateral saddle rounded, symmetric or slightly asymmetric; adventive lobe V-shaped, symmetric or asymmetric.

Included species.

coarta: Temertassetia coarta n. sp.; Mouydir, Algeria.

decorata: Temertassetia decorata n. sp.; Mouydir, Algeria.

minima: Pericyclus minimus Hind, 1910, p. 107; Derbyshire.

multiplicatus: Pericyclus princeps var. multiplicatus Delépine, 1940, p. 40; Belgium.

secunda: Temertassetia secunda n. sp.; Mouydir, Algeria.

temertassetensis: Temertassetia temertassetensis n. sp.; Mouydir, Algeria.

Separation of the new species. The four species of Temertassetia from Oued Temertasset can be separated by their conch morphology and suture line. In the conch shape and its ontogenetic development, they are characterised as follows:

- T. temertassetensis $-\mathrm{ww} / \mathrm{dm} \sim 0.36$ in the adult stage $(28 \mathrm{~mm} \mathrm{dm})$ and $\sim 0.60$ in the intermediate stage $(8 \mathrm{~mm} \mathrm{dm})$; uw/dm $\sim 0.25 \mathrm{in}$ the adult stage $(28 \mathrm{~mm} \mathrm{dm})$ and $\sim 0.20$ in the intermediate stage $(8 \mathrm{~mm} \mathrm{dm})$;

- T. secunda - ww/dm $\sim 0.45$ in the adult stage $(20 \mathrm{~mm} \mathrm{dm})$ and $\sim 0.60$ in the intermediate stage $(8 \mathrm{~mm} \mathrm{dm})$; uw/dm $\sim 0.30 \mathrm{in}$ the adult stage $(20 \mathrm{~mm} \mathrm{dm})$ and $\sim 0.30$ in the intermediate stage $(8 \mathrm{~mm} \mathrm{dm})$;

- T. decorata $-\mathrm{ww} / \mathrm{dm} \sim 0.45$ in the adult stage $(20 \mathrm{~mm} \mathrm{dm})$ and $\sim 0.70$ in the intermediate stage $(8 \mathrm{~mm} \mathrm{dm})$; uw/dm $\sim 0.40 \mathrm{in}$ the adult stage $(20 \mathrm{~mm} \mathrm{dm})$ and $\sim 0.28$ in the intermediate stage $(8 \mathrm{~mm} \mathrm{dm})$;

- T. coarta $-\mathrm{ww} / \mathrm{dm} \sim 0.43$ in the adult stage $(30 \mathrm{~mm} \mathrm{dm})$ and $\sim 0.68$ in the intermediate stage $(8 \mathrm{~mm} \mathrm{dm})$; uw/dm $\sim 0.20$ in the adult stage $(30 \mathrm{~mm} \mathrm{dm})$ and $\sim 0.22$ in the intermediate stage $(8 \mathrm{~mm} \mathrm{dm})$.

The steinkern surface differs in the four specimens:

- T. temertassetensis - biconvex constrictions; faint riblets, additional riblets intercalated in the midflank area;

- T. secunda - concavo-convex constrictions; weak but sharp riblets, without intercalated riblets;

- T. decorata - concavo-convex constrictions; sharp riblets, additional riblets intercalate in the midflank area;

- T. coarta - concavo-convex constrictions; faint riblets, riblets split or intercalate on the midflank.

The suture line offers more distinguishing characters (in specimens larger than $12 \mathrm{~mm} \mathrm{dm}$ ):

- T. temertassetensis - external lobe narrow (EL w/d =0.60-0.70); median saddle low (MS h $\sim 0.20$ );

- T. secunda - external lobe narrow (EL w/d =0.55-0.70); median saddle low (MS $\mathrm{h}=0.20-0.25)$;

- $T$. decorata - external lobe narrow $(\mathrm{EL} \mathrm{w} / \mathrm{d}=0.55-0.70)$; median saddle very low $(\mathrm{MS} \mathrm{h}<0.20)$;

- T. coarta - external lobe very narrow $(\mathrm{EL} w / \mathrm{d}=0.40-0.50)$; median saddle low $(\mathrm{MS} \mathrm{h} \sim 0.25)$. 
Discussion. Temertassetia shows relationships to the genus Pericyclus, and some of the species of Temertassetia (particularly T. decorata) show riblets very similar to Pericyclus. The boundary between the two genera is drawn at the border, when steinkern constrictions become more important than ribs. Jerania differs in the lack of riblets, and Kusinia has a lenticular, very narrowly umbilicate conch that differs strikingly from Temertassetia.

Polaricyclus Riley, 1991 (type species: Ammonellipsites (Fascipericyclus) polaris Gordon, 1957) shows some similarities, but differs in the involute inner whorls (in the type species and in P. canadensis Work \& Nassichuk, 2000) and the external lobe with rather straight flanks, in contrast to the sinuous flanks in Temertassetia.

\section{Temertassetia temertassetensis n. sp.}

\section{Figures 35, 36}

Derivation of name. After the type locality.

Holotype. Specimen MB.C.18947.1, illustrated in Figure 35A

Type locality and horizon. Oued Temertasset, sample MOU-E07 (Mouydir, South Algeria); upper Pericyclus-Progoniatites Assemblage.

Material. 183 specimens, conch diameter up to $28 \mathrm{~mm}$.

Diagnosis. Temertassetia with thickly pachyconic conch in the juvenile stage and continuously becoming more slender and being thinly discoidal at $28 \mathrm{~mm} \mathrm{dm}$; conch subinvolute in all growth stages with a weak trend towards a widening of the umbilicus in the adult stage; umbilical margin subangular, umbilical wall oblique and flat; aperture moderate throughout ontogeny without changes. Steinkern with slightly biconvex constrictions that extend, in the adult stage, with very low projections and a shallow lateral sinus across the flanks forming a deep and narrow ventral sinus; faint riblets between the constrictions on the flanks, additional riblets intercalated in the midflank area. Suture line with narrow V-shaped external lobe and low median saddle; ventrolateral saddle almost symmetric, broadly rounded; adventive lobe V-shaped, acute.

Table 49. Conch ontogeny (Figs 36A, B, F-H) of Temertassetia temertassetensis n. sp.

\begin{tabular}{|c|c|c|c|}
\hline$d m$ & conch shape & whorl cross section shape & aperture \\
\hline $2 \mathrm{~mm}$ & $\begin{array}{l}\text { thickly pachyconic; subinvolute } \\
\text { (ww/dm } \sim 0.75 ; \text { uw/dm } \sim 0.20 \text { ) }\end{array}$ & $\begin{array}{l}\text { moderately depressed; strongly embracing } \\
\text { (ww/wh } \sim 1.65 ; \text { IZR } \sim 0.40 \text { ) }\end{array}$ & $\begin{array}{l}\text { moderate } \\
(\text { WER } \sim 1.85)\end{array}$ \\
\hline $8 \mathrm{~mm}$ & $\begin{array}{l}\text { thinly pachyconic; subinvolute } \\
\text { (ww/dm } \sim 0.60 ; \mathrm{uw} / \mathrm{dm} \sim 0.20 \text { ) }\end{array}$ & $\begin{array}{l}\text { weakly depressed; strongly embracing } \\
\text { (ww/wh }=1.30-1.40 ; \text { IZR } \sim 0.40 \text { ) }\end{array}$ & $\begin{array}{l}\text { moderate } \\
(\mathrm{WER}=1.75-1.85)\end{array}$ \\
\hline $20 \mathrm{~mm}$ & $\begin{array}{l}\text { thinly discoidal; subinvolute } \\
(\mathrm{ww} / \mathrm{dm}=0.40-0.48 ; \mathrm{uw} / \mathrm{dm}=0.20-0.30)\end{array}$ & $\begin{array}{l}\text { weakly compressed to weakly depressed; strongly } \\
\text { embracing (ww/wh }=0.90-1.15 ; \mathrm{IZR}=0.35-0.45 \text { ) }\end{array}$ & $\begin{array}{l}\text { moderate } \\
(\mathrm{WER}=1.75-1.90)\end{array}$ \\
\hline $28 \mathrm{~mm}$ & $\begin{array}{l}\text { thinly discoidal; subinvolute } \\
\text { (ww/dm } \sim 0.36 ; \text { uw/dm } \sim 0.25 \text { ) }\end{array}$ & $\begin{array}{l}\text { weakly compressed; strongly embracing } \\
\text { (ww/wh } \sim 0.85 ; \text { IZR } \sim 0.40 \text { ) }\end{array}$ & $\begin{array}{l}\text { moderate } \\
(\mathrm{WER} \sim 1.75)\end{array}$ \\
\hline
\end{tabular}
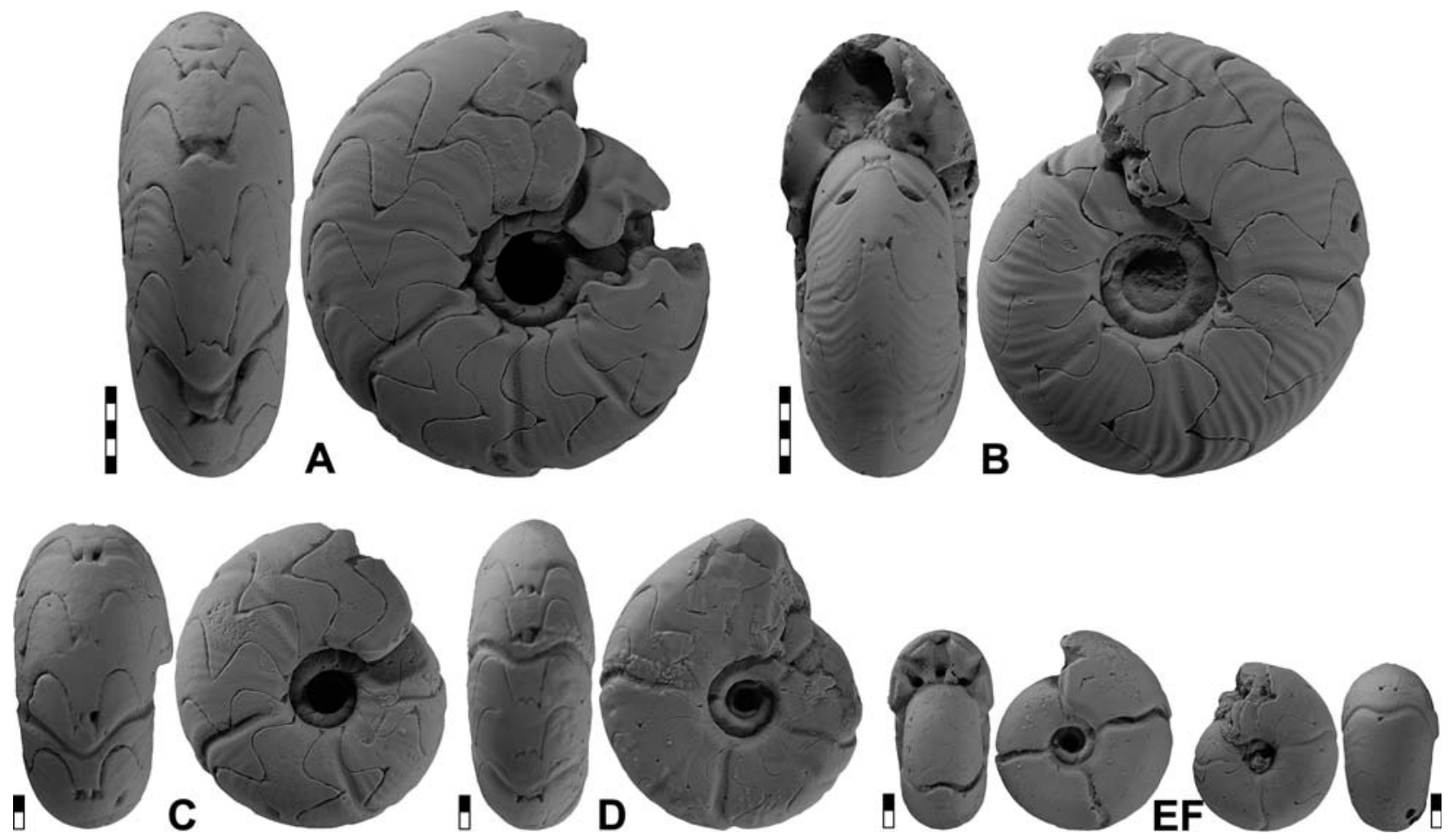
Table 50. Conch dimensions (in $\mathrm{mm}$ ) and proportions for reference specimens of Temertassetia temertassetensis $\mathrm{n}$. sp.

\begin{tabular}{|c|c|c|c|c|c|c|c|c|c|c|}
\hline & $\mathrm{dm}$ & wW & wh & uw & ah & ww/dm & ww/wh & $\mathrm{uw} / \mathrm{dm}$ & WER & IZR \\
\hline holotype MB.C.18947.1 & 27.3 & 10.0 & 11.6 & 6.8 & 6.5 & 0.37 & 0.86 & 0.25 & 1.72 & 0.44 \\
\hline paratype MB.C.18936 & 25.8 & 10.8 & 10.0 & 7.5 & 6.0 & 0.42 & 1.08 & 0.29 & 1.70 & 0.40 \\
\hline paratype MB.C.18865.1 & 18.2 & 8.9 & 7.4 & 4.7 & 4.3 & 0.49 & 1.21 & 0.26 & 1.72 & 0.42 \\
\hline paratype MB.C.18947.2 & 17.4 & 7.2 & 7.4 & 4.3 & 4.2 & 0.42 & 0.98 & 0.25 & 1.74 & 0.43 \\
\hline paratype MB.C.18947.3 & 11.9 & 6.1 & 4.8 & 3.1 & 2.7 & 0.51 & 1.26 & 0.26 & 1.68 & 0.43 \\
\hline paratype MB.C.18865.2 & 9.1 & 5.2 & 4.0 & 1.9 & 2.2 & 0.57 & 1.30 & 0.21 & 1.73 & 0.45 \\
\hline
\end{tabular}

Table 51. Suture line proportions (Figs 36C-E) for Temertassetia temertassetensis n. sp.

\begin{tabular}{llllllll}
\hline specimen & at dm & EL w/d & EL/VLS & EL/AL & MS h & VLS w/h & remarks \\
\hline holotype MB.C.18947.1 & $24.2 \mathrm{~mm}$ & 0.67 & 0.82 & 1.40 & 0.21 & 0.82 & prongs of E lobe hook-shaped \\
paratype MB.C.18947.2 & $15.7 \mathrm{~mm}$ & 0.60 & 0.88 & 0.94 & 0.20 & 0.69 & M saddle very low \\
paratype MB.C.18947.3 & $10.9 \mathrm{~mm}$ & 0.66 & 0.84 & 1.21 & 0.13 & 0.79 & \\
\hline
\end{tabular}
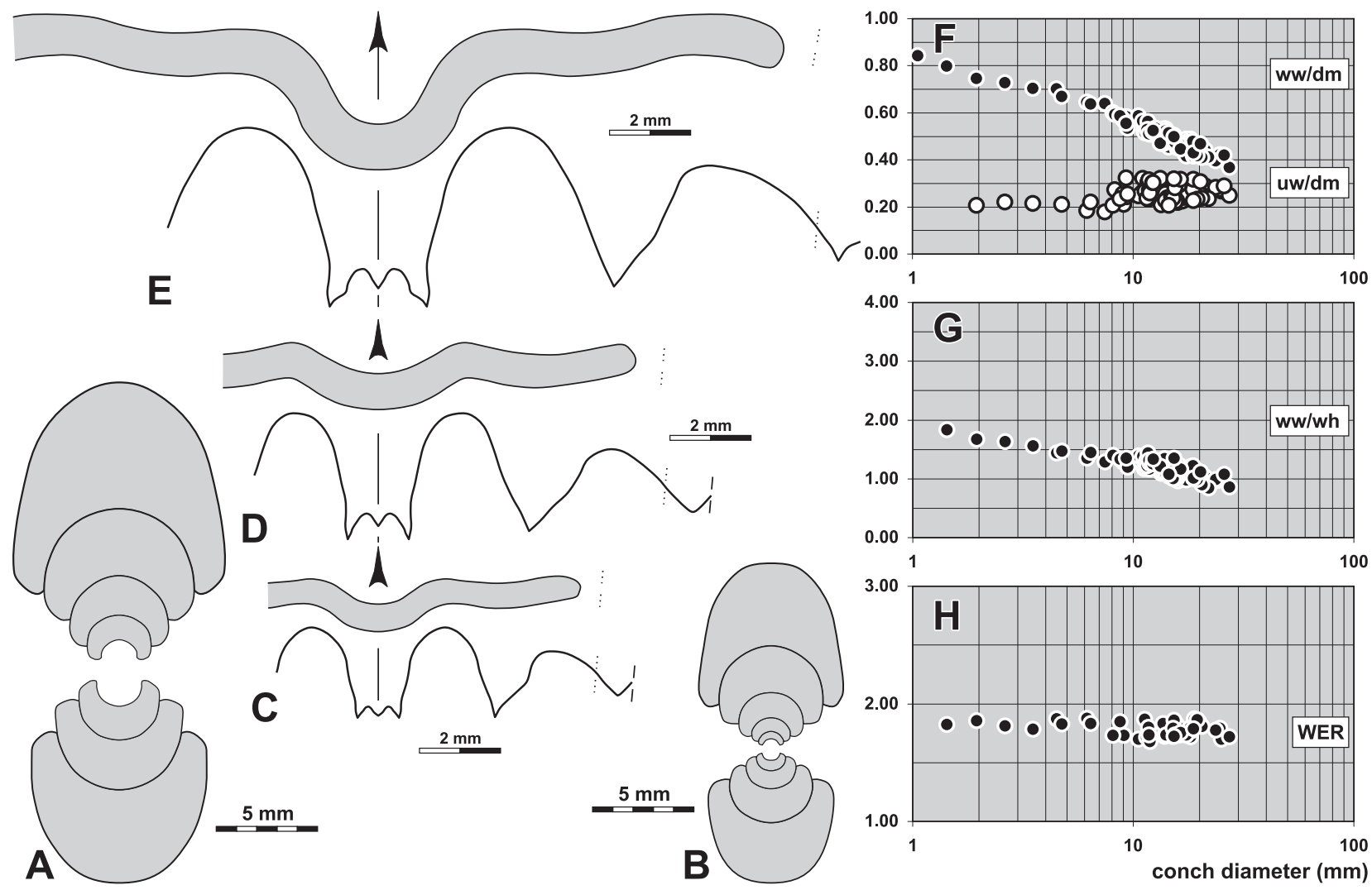

Figure 36. Temertassetia temertassetensis n. sp. A. Cross section of paratype MB.C.18865.3 from locality MOU-D1; $\times 2.5$. B. Cross section of paratype MB.C.18947.4 from locality MOU-E07; $\times 2.5$. C. Suture line and constriction of paratype MB.C.18947.3 from locality MOU-E07, at $10.9 \mathrm{~mm} \mathrm{dm}, 5.5 \mathrm{~mm}$ ww, $5.5 \mathrm{~mm}$ wh; $\times 5.0$. D. Suture line and constriction of paratype MB.C.18947.2 from locality MOU-E07, at $15.7 \mathrm{~mm} \mathrm{dm}, 7.2 \mathrm{~mm}$ ww, $7.2 \mathrm{~mm}$ wh; $\times 5.0$. E. Suture line and constriction of holotype MB.C.18947.1 from locality MOU-E07, at $24.2 \mathrm{~mm} \mathrm{dm}, 9.7 \mathrm{~mm}$ ww, $10.8 \mathrm{~mm} \mathrm{wh} \times 5.0$. F-H. Ontogenetic development of the conch width index (ww/dm), umbilical width index (uw/dm), whorl width index (ww/wh), and whorl expansion rate (WER) of all available specimens.

Figure 35. Temertassetia temertassetensis n. sp.; all $\times 2$. A. Holotype MB.C.18947.1 from locality MOU-E07. B. Paratype MB.C.18936 from locality MOU-E06. C. Paratype MB.C.18865.1 from locality MOU-D1. D. Paratype MB.C.18947.2 from locality MOU-E07. E. Paratype MB.C.18947.3 from locality MOU-E07. F. Paratype MB.C.18865.2 from locality MOU-D1. 


\section{Temertassetia secunda n. sp.}

Figures 37,38

Derivation of name. From Latin secunda = the second, it accompanies the type species.

Holotype. Specimen MB.C.18948.1, illustrated in Figure 37A.

Type locality and horizon. Oued Temertasset, locality and sample MOU-E07 (Mouydir, South Algeria); upper Pericyclus-Progoniatites Assemblage. Material. 107 specimens, conch diameter up to $27 \mathrm{~mm}$.

Diagnosis. Temertassetia with thickly pachyconic conch in the juvenile stage and continuously becoming more slender and being thinly discoidal at $20 \mathrm{~mm} \mathrm{dm}$; conch subinvolute in early and intermediate growth stages, widening of the umbilicus causes a subinvolute or subevolute conch in the adult stage; umbilical margin subangular, umbilical wall steep and flattened; aperture moderate or low throughout ontogeny without significant changes. Steinkern with concavo-convex constrictions that extend, in the adult stage, with a very shallow lateral sinus across the flanks and form a moderately deep and narrow ventral sinus; weak but rather sharp riblets between the constrictions on the flanks, without intercalated riblets. Suture line with narrow, V-shaped external lobe and low median saddle; ventrolateral saddle almost symmetric, broadly rounded; adventive lobe V-shaped, strongly asymmetric.

Table 52. Conch ontogeny (Figs 38A, B, F-H) of Temertassetia secunda n. sp.

\begin{tabular}{|c|c|c|c|}
\hline $\mathrm{dm}$ & conch shape & whorl cross section shape & aperture \\
\hline $2 \mathrm{~mm}$ & $\begin{array}{l}\text { thinly or thickly pachyconic; subinvolute } \\
\text { (ww/dm }=0.68-0.75 ; \text { uw/dm } \sim 0.24 \text { ) }\end{array}$ & $\begin{array}{l}\text { moderately depressed; strongly embracing } \\
\text { (ww/wh } \sim 1.70 \text {; IZR } \sim 0.40 \text { ) }\end{array}$ & $\begin{array}{l}\text { low } \\
\text { (WER 1.65) }\end{array}$ \\
\hline $8 \mathrm{~mm}$ & $\begin{array}{l}\text { thickly discoidal to thinly pachyconic; } \\
\text { subinvolute to subevolute } \\
\text { (ww/dm }=0.55-0.65 ; \text { uw/dm }=0.27-0.35 \text { ) }\end{array}$ & $\begin{array}{l}\text { weakly depressed; strongly embracing } \\
\text { (ww/wh }=1.40-1.50 ; \text { IZR } \sim 0.42)\end{array}$ & $\begin{array}{l}\text { moderate } \\
(\text { WER } \sim 1.80)\end{array}$ \\
\hline $20 \mathrm{~mm}$ & $\begin{array}{l}\text { thinly discoidal; subinvolute to subevolute } \\
(\mathrm{ww} / \mathrm{dm}=0.40-0.50 ; \mathrm{uw} / \mathrm{dm}=0.27-0.35 \text { ) }\end{array}$ & $\begin{array}{l}\text { weakly depressed; strongly embracing } \\
(\mathrm{ww} / \mathrm{wh}=1.00-1.30 ; \mathrm{IZR}=0.35-0.45)\end{array}$ & $\begin{array}{l}\text { low } \\
(\text { WER }=1.60-1.75)\end{array}$ \\
\hline
\end{tabular}

Table 53. Conch dimensions (in $\mathrm{mm}$ ) and proportions for reference specimens of Temertassetia secunda $\mathrm{n}$. sp.

\begin{tabular}{lllllllllll}
\hline & $\mathrm{dm}$ & ww & wh & uw & ah & ww/dm & ww/wh & uw/dm & WER & IZR \\
\hline holotype MB.C.18948.1 & 23.1 & 9.8 & 8.8 & 7.6 & 4.6 & 0.42 & 1.11 & 0.33 & 1.56 & 0.47 \\
paratype MB.C.18948.2 & 18.4 & 8.5 & 7.6 & 5.1 & 4.2 & 0.46 & 1.12 & 0.28 & 1.69 & 0.44 \\
paratype MB.C.18948.3 & 10.6 & 5.8 & 4.3 & 2.8 & 2.3 & 0.55 & 1.34 & 0.27 & 1.64 & 0.46 \\
\hline
\end{tabular}

Table 54. Suture line proportions (Figs $38 \mathrm{C}-\mathrm{E}$ ) for Temertassetia secunda $\mathrm{n}$. sp.

\begin{tabular}{llllllll}
\hline specimen & at dm & EL w/d & EL/VLS & EL/AL & MS h & VLS w/h & remarks \\
\hline holotype MB.C.18948.1 & $21.7 \mathrm{~mm}$ & 0.60 & 0.86 & 1.19 & 0.20 & 0.69 & A lobe very asymmetric \\
paratype MB.C.18948.2 & $16.6 \mathrm{~mm}$ & 0.55 & 0.82 & 1.26 & 0.25 & 0.67 & M saddle comparatively high \\
paratype MB.C.18948.3 & $10.1 \mathrm{~mm}$ & 0.70 & 0.89 & 1.21 & 0.14 & 0.78 & E lobe with incurved flanks \\
\hline
\end{tabular}
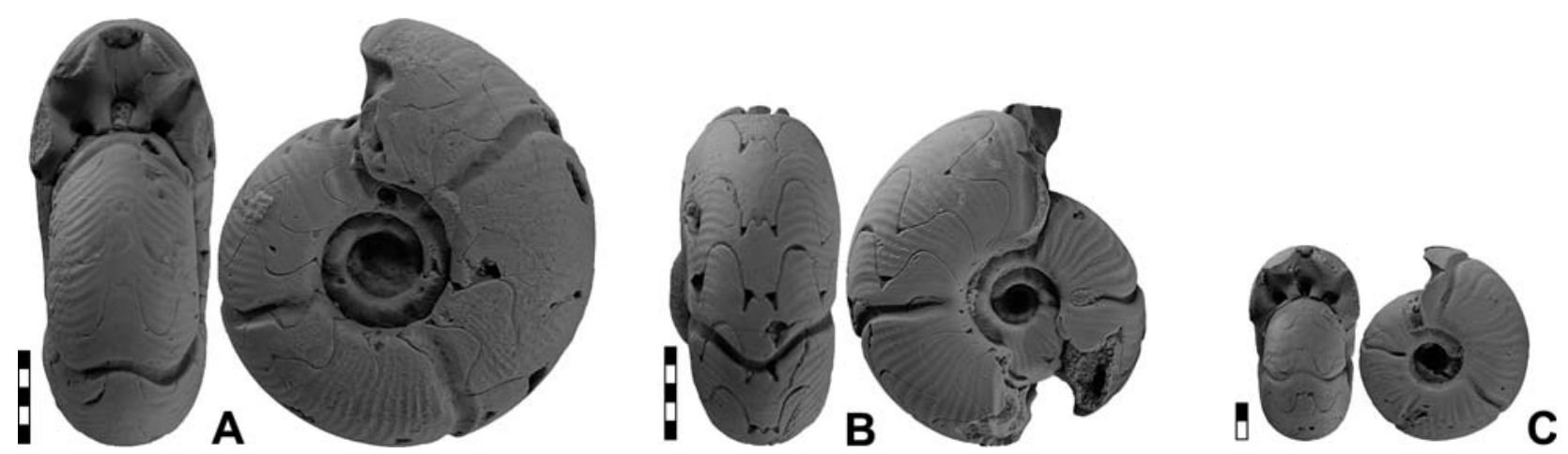

Figure 37. Temertassetia secunda n. sp. from locality MOU-E07; all ×2. A. Holotype MB.C.18948.1. B. Paratype MB.C.18948.2. C. Paratype MB.C.18948.3. 


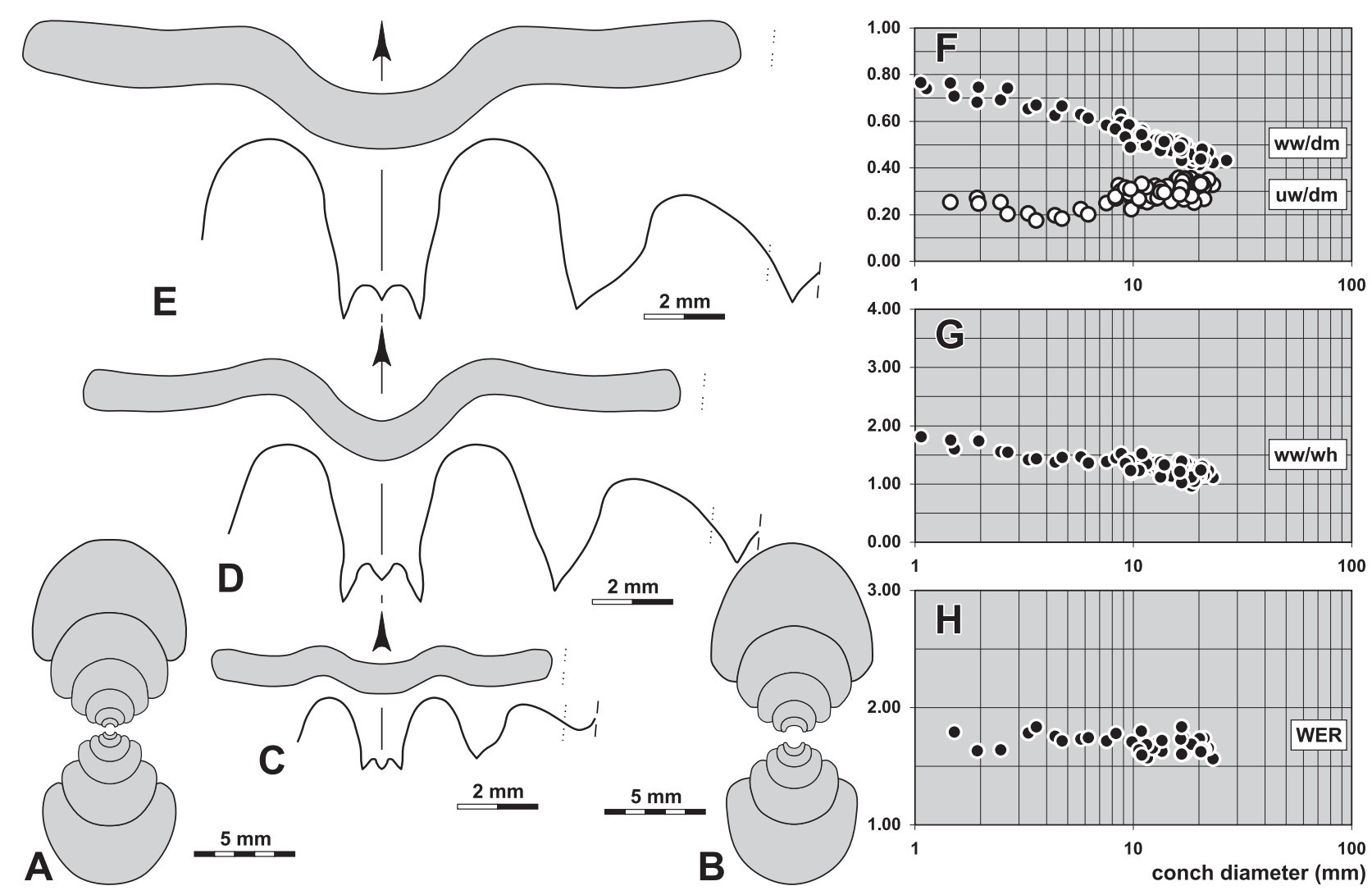

Figure 38. Temertassetia secunda n. sp. from locality MOU-E07. A. Cross section of paratype MB.C.18948.4; $\times 2.5$. B. Cross section of paratype MB.C.18948.5; $\times 2.5$. C. Suture line and constriction of paratype MB.C.18948.3, at $10.1 \mathrm{~mm} \mathrm{dm}, 5.6 \mathrm{~mm}$ ww, $4.2 \mathrm{~mm}$ wh; $\times 5.0$. D. Suture line and constriction of paratype MB.C.18948.2, at $16.6 \mathrm{~mm} \mathrm{dm}, 8.4 \mathrm{~mm}$ ww, $7.8 \mathrm{~mm}$ wh; $\times 5.0$. E. Suture line and constriction of holotype MB.C.18948.1, at $21.7 \mathrm{~mm} \mathrm{dm}, 9.7 \mathrm{~mm} \mathrm{ww}, 8.8 \mathrm{~mm}$ wh; $\times 5.0$. F-H. Ontogenetic development of the conch width index (ww/dm), umbilical width index (uw/dm), whorl width index (ww/wh), and whorl expansion rate (WER) of all available specimens.

\section{Temertassetia decorata n. sp.}

Figures 39, 40

Derivation of name. From Latin decorata, because of the well-decorated conch.

Holotype. Specimen MB.C.19072.1, illustrated in Figure 39B.

Type locality and horizon. Oued Temertasset, locality and sample MOU-Les (Mouydir, South Algeria); upper Pericyclus-Progoniatites Assemblage.

Material. 149 specimens, conch diameter up to $26 \mathrm{~mm}$.

Diagnosis. Temertassetia with thickly pachyconic conch in the early juvenile stage, above $4 \mathrm{~mm} \mathrm{dm}$ continuously becoming more slender and being thinly discoidal at $25 \mathrm{~mm} \mathrm{dm}$; conch subevolute throughout ontogeny with a subinvolute interval between 3 and $9 \mathrm{~mm}$ dm; umbilical margin subangular, umbilical wall steep and flattened; aperture low throughout ontogeny without significant changes. Steinkern with concavo-convex constrictions, often arranged in distances of $90^{\circ}$, course with a shallow lateral sinus across the flanks and a deep sinus on the venter; sharp riblets between the constrictions on the flanks, additional riblets intercalate in the midflank area. Suture line with narrow, V-shaped external lobe with a very low median saddle and hook-shaped secondary prongs; ventrolateral saddle almost symmetric, narrowly rounded; adventive lobe V-shaped, asymmetric.

Table 55. Conch ontogeny (Figs 40A, B, E-H) of Temertassetia decorata n. sp.

\begin{tabular}{llll}
\hline $\mathrm{dm}$ & conch shape & whorl cross section shape & aperture \\
\hline $2 \mathrm{~mm}$ & thinly pachyconic; subevolute & moderately depressed; strongly embracing & low \\
& $($ ww/dm $\sim 0.70 ;$ uw/dm $\sim 0.35)$ & $($ ww/wh $\sim 1.80 ;$ IZR $\sim 0.40)$ & $($ WER $\sim 1.70)$ \\
$8 \mathrm{~mm}$ & thickly discoidal; subinvolute & moderately depressed; strongly embracing & low \\
& $($ ww/dm $\sim 0.60 ;$ uw/dm $\sim 0.28)$ & $($ ww/wh $=1.50-1.75 ;$ IZR $\sim 0.40)$ & $($ WER $\sim 1.70)$ \\
$20 \mathrm{~mm}$ & thinly discoidal; subevolute & weakly to moderately depressed; strongly embracing & low \\
& $($ ww/dm $=0.40-0.50 ;$ uw/dm $=0.33-0.45)$ & $($ ww/wh $=1.10-1.65 ;$ IZR $=0.30-0.40)$ & $($ WER $=1.50-1.70)$ \\
\hline
\end{tabular}


Table 56. Conch dimensions (in $\mathrm{mm}$ ) and proportions for reference specimens of Temertassetia decorata $\mathrm{n}$. sp.

\begin{tabular}{lcccccccccc}
\hline & $\mathrm{dm}$ & ww & wh & uw & ah & ww/dm & ww/wh & uw/dm & WER & IZR \\
\hline paratype MB.C.18725 & 24.8 & 10.2 & 9.2 & 8.9 & 5.7 & 0.41 & 1.11 & 0.36 & 1.68 & 0.38 \\
holotype MB.C.19072.1 & 21.9 & 9.7 & 7.3 & 9.5 & 4.4 & 0.44 & 1.33 & 0.43 & 1.56 & 0.40 \\
paratype MB.C.18949.1 & 21.2 & 9.5 & 7.1 & 10.2 & 4.4 & 0.45 & 1.34 & 0.48 & 1.59 & 0.38 \\
paratype MB.C.19072.2 & 18.5 & 9.0 & 5.8 & 8.3 & 3.4 & 0.49 & 1.57 & 0.45 & 1.50 & 0.41 \\
paratype MB.C.18867.1 & 14.4 & 8.1 & 5.1 & 6.1 & 3.2 & 0.56 & 1.60 & 0.42 & 1.65 & 0.37 \\
paratype MB.C.18891.1 & 14.0 & 7.6 & 4.6 & 6.7 & 2.8 & 0.55 & 1.68 & 0.48 & 1.56 & 0.39 \\
paratype MB.C.18891.2 & 13.0 & 6.3 & 4.7 & 5.2 & 2.8 & 0.48 & 1.34 & 0.40 & 1.61 & 0.41 \\
\hline
\end{tabular}

Table 57. Suture line proportions (Figs 40C, D) for Temertassetia decorata $\mathrm{n}$. sp.

\begin{tabular}{llllllll}
\hline specimen & at dm & EL w/d & EL/NLS & EL/AL & MS h & VLS w/h & remarks \\
\hline paratype MB.C.18949.4 & $24.2 \mathrm{~mm}$ & 0.59 & 0.95 & 1.22 & 0.19 & 0.62 & \\
paratype MB.C.18949.3 & $15.7 \mathrm{~mm}$ & 0.70 & 0.91 & 1.18 & 0.20 & 0.77 & prongs of E lobe narrowly rounded \\
\hline
\end{tabular}

Discussion. Temertassetia decorata shows some resemblance to species of the genera Pericyclus and Helicocyclus. The co-occurrence of sharp ribs and steinkern constrictions is also known from Pericyclus intercisus, but this species has a wider conch and shows clear differences in the suture line: the external lobe has almost parallel flanks and possesses lanceolate secondary prongs, unlike the hook-shaped prongs of T. decorata. H. formosus has weaker ribs and a suture line with a wider external lobe and a much higher median saddle.
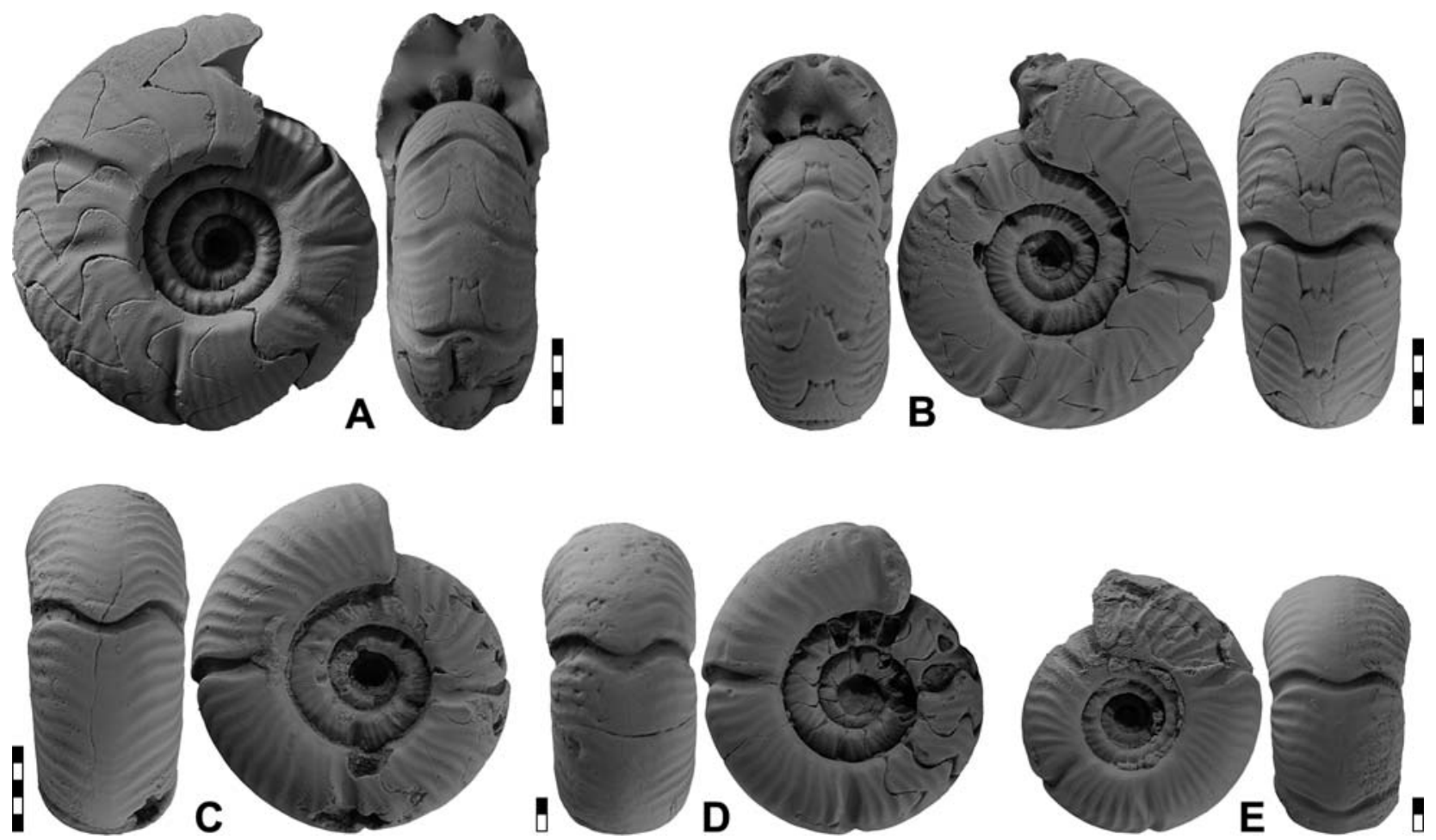

Figure 39. Temertassetia decorata n. sp.; all $\times 2$. A. Paratype MB.C.18725 from locality A-264. B. Holotype MB.C.19072.1 from an unrecorded locality. C. Paratype MB.C.18949.1 from locality MOU-E07. D. Paratype MB.C.19072.2 from an unrecorded locality. E. Paratype MB.C.18867.1 from locality MOU-D1. 

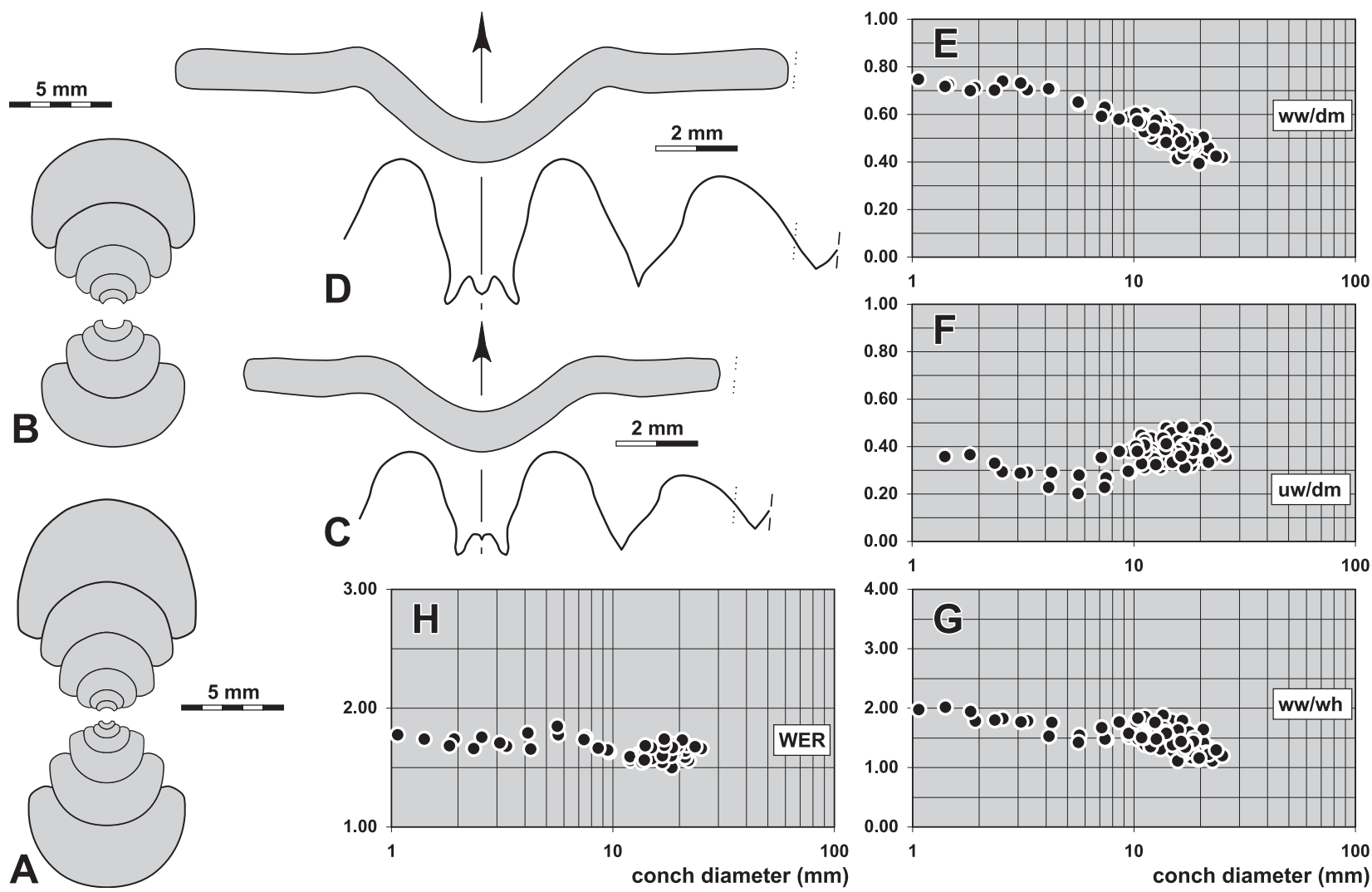

Figure 40. Temertassetia decorata $n$. sp. A. Cross section of paratype MB.C. 18949.2 from locality MOU-E07; $\times 2.5$. B. Cross section of paratype MB.C.18867.2 from locality MOU-D1; $\times 2.5$. C. Suture line and constriction of paratype MB.C.18949.3 from locality MOU-E07, at $14.1 \mathrm{~mm} \mathrm{dm}, 7.5 \mathrm{~mm}$ ww, $5.7 \mathrm{~mm}$ wh; $\times 5.0$. D. Suture line and constriction of paratype MB.C.18949.4 from locality MOU-E07, at $19.2 \mathrm{~mm} \mathrm{dm}, 9.0 \mathrm{~mm}$ ww, $7.8 \mathrm{~mm}$ wh; $\times 5.0$. E-H. Ontogenetic development of the conch width index (ww/dm), umbilical width index (uw/dm), whorl width index (ww/wh), and whorl expansion rate (WER) of all available specimens.

\section{Temertassetia coarta $\mathbf{n}$. sp.}

Figures 41,42

Derivation of name. From Latin co-artus = narrowing, because of the narrow external lobe.

Holotype. Specimen MB.C.18868.1, illustrated in Figure 41A.

Type locality and horizon. Oued Temertasset, locality and sample MOU-D1 (Mouydir, South Algeria); upper Pericyclus-Progoniatites Assemblage. Material. 183 specimens, conch diameter up to $34 \mathrm{~mm}$.

Diagnosis. Temertassetia with thinly pachyconic conch in the early juvenile stage, above $8 \mathrm{~mm} \mathrm{dm}$ continuously becoming more slender and being thinly discoidal at $30 \mathrm{~mm} \mathrm{dm}$; conch subevolute in early juveniles up to $3 \mathrm{~mm} \mathrm{dm}$ and later subinvolute; umbilical margin subangular, umbilical wall steep and flat; aperture low or moderate throughout ontogeny without significant changes. Steinkern with constrictions of different prominence, course concavo-convex with a wide projection across the flanks and a rather deep, narrow ventral sinus; faint riblets between the constrictions on the flanks, they often split or intercalate on the midflank. Suture line with very narrow external lobe with subparallel flanks and low median saddle; ventrolateral saddle almost symmetric, broadly rounded; adventive lobe V-shaped with almost straight flanks.

Table 58. Conch ontogeny (Figs $42 \mathrm{~A}-\mathrm{E}, \mathrm{I}-\mathrm{K}$ ) of Temertassetia coarta $\mathrm{n}$. sp.

\begin{tabular}{|c|c|c|c|}
\hline $\mathrm{dm}$ & conch shape & whorl cross section shape & aperture \\
\hline $2 \mathrm{~mm}$ & $\begin{array}{l}\text { thinly to thickly pachyconic; subevolute } \\
(\mathrm{ww} / \mathrm{dm}=0.67-0.74 ; \mathrm{uw} / \mathrm{dm}=0.35-0.40)\end{array}$ & $\begin{array}{l}\text { moderately depressed; strongly embracing } \\
\text { (ww/wh } \sim 1.95 ; \text { IZR } \sim 0.30 \text { ) }\end{array}$ & $\begin{array}{l}\text { low to moderate } \\
\text { (WER }=1.70-1.80)\end{array}$ \\
\hline $8 \mathrm{~mm}$ & $\begin{array}{l}\text { thinly pachyconic; subinvolute } \\
(\text { ww/dm }=0.65-0.70 ; \text { uw } / \mathrm{dm}=0.18-0.25)\end{array}$ & $\begin{array}{l}\text { weakly or moderately depressed; strongly embracing } \\
\text { (ww/wh }=1.30-1.60 ; \text { IZR } \sim 0.38 \text { ) }\end{array}$ & $\begin{array}{l}\text { moderate } \\
(\text { WER }=1.80-1.90)\end{array}$ \\
\hline $20 \mathrm{~mm}$ & $\begin{array}{l}\text { thickly discoidal; subinvolute } \\
(\mathrm{ww} / \mathrm{dm}=0.48-0.55 ; \mathrm{uw} / \mathrm{dm}=0.18-0.30)\end{array}$ & $\begin{array}{l}\text { weakly depressed; strongly embracing } \\
(\mathrm{ww} / \mathrm{wh}=1.00-1.40 ; \mathrm{IZR}=0.38-0.45)\end{array}$ & $\begin{array}{l}\text { low to moderate } \\
(\mathrm{WER}=1.70-1.90)\end{array}$ \\
\hline $30 \mathrm{~mm}$ & $\begin{array}{l}\text { thinly discoidal; subinvolute } \\
(\mathrm{ww} / \mathrm{dm} \sim 0.43 ; \mathrm{uw} / \mathrm{dm}=0.15-0.25)\end{array}$ & $\begin{array}{l}\text { weakly depressed; strongly embracing } \\
\text { (ww/wh }=1.00-1.10 ; \mathrm{IZR}=0.40-0.45)\end{array}$ & $\begin{array}{l}\text { moderate } \\
(\mathrm{WER}=1.80-1.90)\end{array}$ \\
\hline
\end{tabular}


Table 59. Conch dimensions (in $\mathrm{mm}$ ) and proportions for reference specimens of Temertassetia coarta $\mathrm{n}$. sp.

\begin{tabular}{lcccccccccc}
\hline & $\mathrm{dm}$ & ww & wh & uw & ah & ww/dm & ww/wh & uw/dm & WER & IZR \\
\hline paratype MB.C.18868.9 & 28.2 & 13.6 & 13.0 & 5.4 & 7.3 & 0.48 & 1.04 & 0.19 & 1.82 & 0.44 \\
holotype MB.C.18868.1 & 26.0 & 12.3 & 12.8 & 5.5 & 6.8 & 0.47 & 0.96 & 0.21 & 1.83 & 0.47 \\
paratype MB.C.18868.2 & 21.9 & 11.4 & 10.7 & 4.4 & 6.0 & 0.52 & 1.07 & 0.20 & 1.91 & 0.44 \\
paratype MB.C.19073.1 & 18.3 & 9.3 & 7.5 & 5.4 & 4.3 & 0.51 & 1.24 & 0.29 & 1.71 & 0.43 \\
paratype MB.C.18868.3 & 15.7 & 8.6 & 6.8 & 3.3 & 4.0 & 0.55 & 1.27 & 0.21 & 1.81 & 0.41 \\
paratype MB.C.19073.2 & 13.3 & 7.4 & 5.5 & 3.9 & 3.0 & 0.56 & 1.35 & 0.30 & 1.67 & 0.45 \\
\hline
\end{tabular}

Table 60. Suture line proportions (Figs $42 \mathrm{~F}-\mathrm{H}$ ) for Temertassetia coarta $\mathrm{n}$. sp.

\begin{tabular}{llllllll}
\hline specimen & at dm & EL w/d & EL/NLS & EL/AL & MS h & VLS w/h & remarks \\
\hline holotype MB.C.18868.1 & $24.5 \mathrm{~mm}$ & 0.39 & 0.54 & 1.12 & 0.24 & 0.73 & flanks of A lobe almost straight \\
paratype MB.C.18868.2 & $21.8 \mathrm{~mm}$ & 0.49 & 0.64 & 1.36 & 0.27 & 0.77 & E lobe slightly pouched \\
paratype MB.C.18868.3 & $14.8 \mathrm{~mm}$ & 0.46 & 0.59 & 0.97 & 0.25 & 0.77 & \\
\hline
\end{tabular}

Discussion. Temertassetia coarta has, within the genus Temertassetia, a similar position like Jerania persimilis in the genus Jerania, i.e. it is a homeomorph of a species that is only clearly separable by the suture line. As $J$. persimilis differs from $J$. jeranensis, T. coarta differs from T. temertassetensis in the very narrow external lobe with subparallel flanks. This mosaic pattern in the distribution of characters cannot be explained at this time.
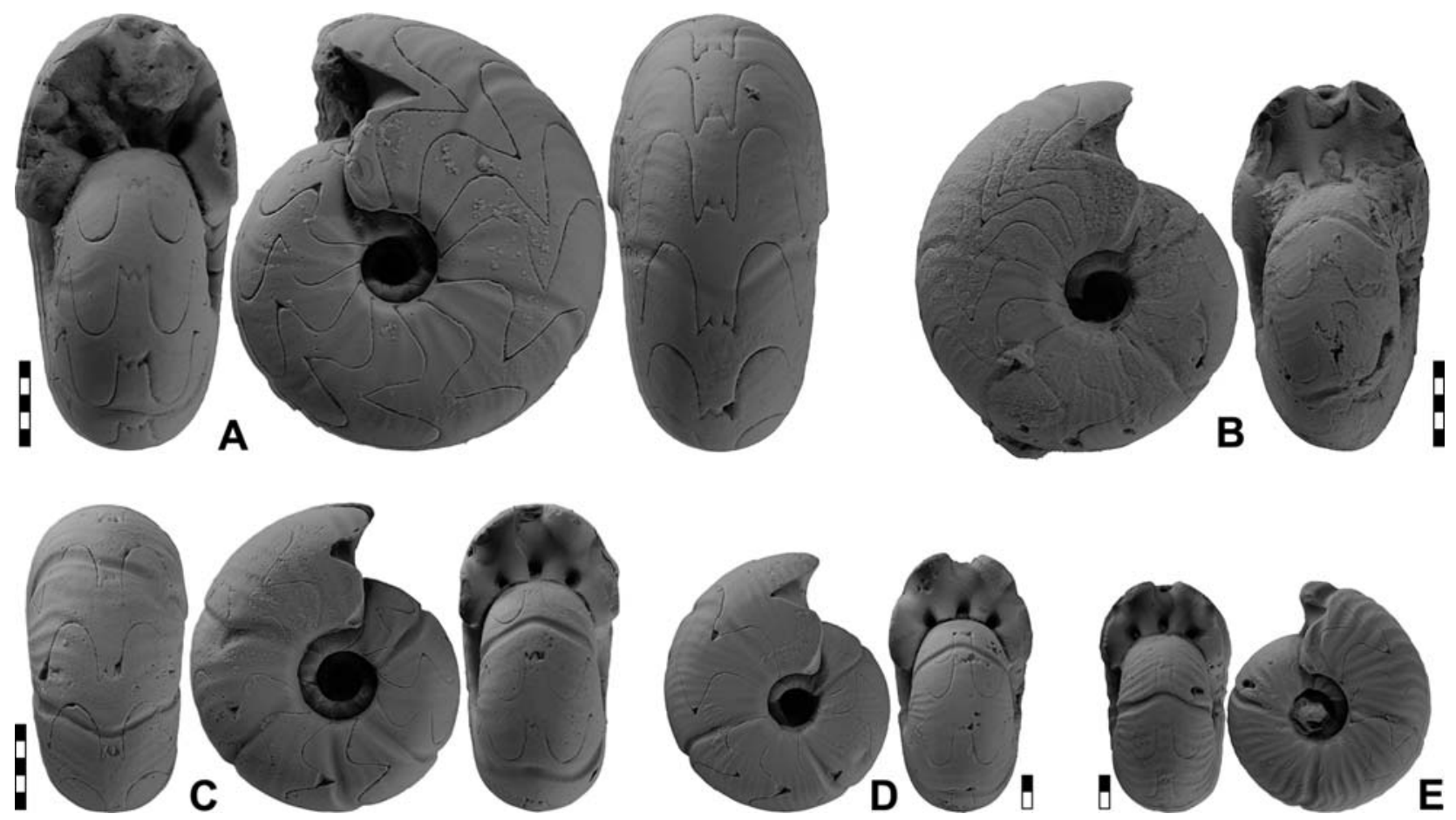

Figure 41. Temertassetia coarta n. sp.; all $\times 2$. A. Holotype MB.C.18868.1 from locality MOU-D1. B. Paratype MB.C.18868.2 from locality MOU-D1. C. Paratype MB.C.19073.1 from locality MOU-Les. D. Paratype MB.C.18868.3 from locality MOU-D1. E. Paratype MB.C.19073.2 from locality MOU-Les. 


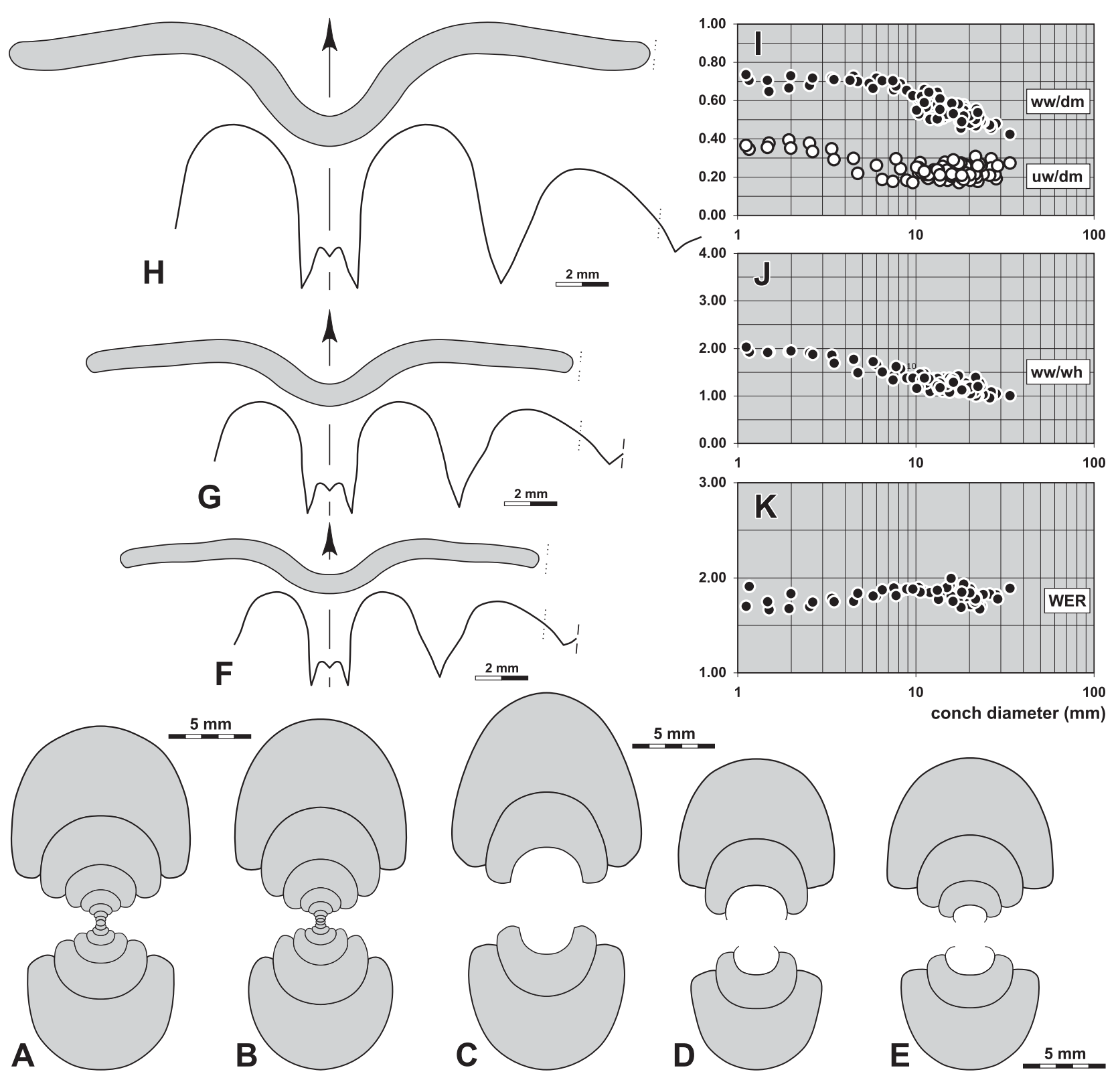

Figure 42. Temertassetia coarta n. sp. A. Cross section of paratype MB.C.18868.4 from locality MOU-D1; $\times 2.5$. B. Cross section of paratype MB.C.18868.5 from locality MOU-D1; $\times 2.5$. C. Cross section of paratype MB.C.18868.6 from locality MOU-D1; $\times 2.5$. D. Cross section of paratype MB.C.18868.7 from locality MOU-D1; $\times 2.5$. E. Cross section of paratype MB.C.18868.8 from locality MOU-D1; $\times 2.5$. F. Suture line and constriction of paratype MB.C.18868.3 from locality MOU-D1, at $14.8 \mathrm{~mm} \mathrm{dm}$, $8.2 \mathrm{~mm}$ ww, $6.8 \mathrm{~mm}$ wh; $\times 4.0$. G. Suture line and constriction of paratype MB.C.18868.2 from locality MOU-D1, at $21.8 \mathrm{~mm} \mathrm{dm}$, $11.8 \mathrm{~mm}$ ww, $10.9 \mathrm{~mm}$ wh; $\times$ 4.0. H. Suture line and constriction of holotype MB.C.18868.1 from locality MOU-D1, at $24.5 \mathrm{~mm}$ $\mathrm{dm}, 11.8 \mathrm{~mm}$ ww, $11.9 \mathrm{~mm}$ wh; $\times 4.0$. I-K. Ontogenetic development of the conch width index (ww/dm), umbilical width index (uw/dm), whorl width index (ww/wh), and whorl expansion rate (WER) of all available specimens.

\section{Jerania n. gen.}

Derivation of name. After Djebel El Jerane in the Mouydir.

Type species. Jerania jeranensis $\mathrm{n}$. sp.

Genus definition. Temertassetiidae with rather small conch, reaching a conch diameter of $50 \mathrm{~mm}$. Early whorls subinvolute, slight closure of the umbilicus in juvenile stages smaller than $5 \mathrm{~mm}$ conch diameter. Steinkern with prominent biconvex constrictions. Suture line with V-shaped, very narrow or narrow external lobe $(\mathrm{EL} w / \mathrm{d}=0.45-0.75 ; \mathrm{EL} / \mathrm{AL}=0.85-1.35)$ and very low or low median saddle $(\mathrm{MS} \mathrm{h}=0.08-0.35)$; ventrolateral saddle rounded, slightly asymmetric; adventive lobe V-shaped, symmetric or asymmetric.

Included species.

antiatlanteum: Winchelloceras antiatlanteum Korn, Bockwinkel, Ebbighausen \& Klug, 2003, p. 87; Anti-Atlas, Morocco.

complanatum: Goniatites complanatus de Koninck, 1880, p. 106; Belgium. 
jeranensis: Jerania jeranensis n. sp.; Mouydir, Algeria. persimilis: Jerania persimilis n. sp.; Mouydir, Algeria. pusillens: Jerania pusillens n. sp.; Mouydir, Algeria. sicilicula: Jerania sicilicula n. sp.; Mouydir, Algeria.

Separation of the new species. The four species of Jerania from Oued Temertasset can be separated by means of conch morphology and the suture line. Based on conch morphology, they can be distinguished as follows:

- J. jeranensis and J. persimilis - uw/dm ratio rather constant between 10 and $30 \mathrm{~mm}$ diameter, with an average value close to 0.20 and a range between 0.15 and 0.24 ;

- J. sicilicula - uw/dm ratio amounts, between 10 and $30 \mathrm{~mm}$ diameter, an average value of 0.12 ;

- J. pusillens and J. subvexa - uw/dm ratio always low, ranging between 0.05 and 0.12 .

The suture line offers further differences:

- J. jeranensis - width/height ratio of the external lobe is, in specimens larger than $10 \mathrm{~mm}$ dm, between about 0.60 and 0.75 ; the median saddle reaches, in the largest specimens $(30 \mathrm{~mm} \mathrm{dm})$ a height of 0.35 of the external lobe depth;

- J. sicilicula - width/height ratio of the external lobe is, in specimens larger than $10 \mathrm{~mm} \mathrm{dm}$, between about 0.55 and 0.70 ; the median saddle reaches, in the largest specimens $(17 \mathrm{~mm} \mathrm{dm})$ a height of 0.10 of the external lobe depth;

- J. pusillens - width/height ratio of the external lobe is, in specimens of $10 \mathrm{~mm} \mathrm{dm}$, about 0.55 ; the median saddle reaches, in the largest specimens $(10 \mathrm{~mm} \mathrm{dm})$ a height of 0.15 of the external lobe depth, adventive lobe $\mathrm{V}$-shaped and acute;

- J. subvexa - width/height ratio of the external lobe is, in specimens of $20 \mathrm{~mm} \mathrm{dm}$, about 0.50 ; the median saddle reaches, in the largest specimens $(20 \mathrm{~mm} \mathrm{dm})$ a height of 0.15 of the external lobe depth, adventive lobe V-shaped and blunt;

- J. persimilis - width/height ratio of the external lobe is, in specimens larger than $10 \mathrm{~mm}$ dm, slightly less than 0.50 ; the median saddle reaches, in the largest specimens $(20-30 \mathrm{~mm} \mathrm{dm})$ a height of 0.25 of the external lobe depth.

Discussion. Some species of Jerania resemble species of the genus Temertassetia in conch shape and ornament. Temertassetia temertassetensis, for example is a species that has a wider umbilicus (uw/dm $\sim 0.28$ ) than Jerania jeranensis (uw/dm $\sim 0.20$ ), and the aperture is slightly lower (WER 1.80 at $20 \mathrm{~mm} \mathrm{dm}$ in Temertassetia temertassetensis, 1.95 in Jerania jeranensis). The ornament shows more differences, with stronger riblets in Temertassetia temertassetensis; more and deeper steinkern constrictions and a riblet-like folding on the flanks between the constrictions. The umbilical margin is sharper, sometimes rim-like, in Temertassetia.

Winchelloceras Ruzhencev, 1965 (type species: Goniatites allei Winchell, 1862) has a very similar conch morphology and also ornament, but possesses a much wider external lobe. Winchelloceras may be a close relative of Jerania, being derived by significant widening of the external lobe.

\section{Jerania jeranensis $\mathbf{n}$. sp.}

Figures 43, 44

Derivation of name. After Djebel El Jerane near the type locality.

Holotype. Specimen MB.C.18950.1, illustrated in Figure 43D.

Type locality and horizon. Oued Temertasset, locality and sample MOU-E07 (Mouydir, South Algeria); upper Pericyclus-Progoniatites Assemblage.

Material. 180 specimens, conch diameter up to $46 \mathrm{~mm}$.

Diagnosis. Jerania with thickly pachyconic conch in the early juvenile stage, continuously becoming more slender and being thinly discoidal at $30 \mathrm{~mm} \mathrm{dm}$; conch subinvolute throughout ontogeny with an involute interval between 4 and $7 \mathrm{~mm}$ dm; umbilicus funnel-shaped with subangular margin and oblique umbilical wall; aperture moderately high throughout ontogeny. Steinkern with biconvex constrictions that extend with low projections and a shallow lateral sinus across the flanks and form a deep and narrow ventral sinus. Suture line with narrow, V-shaped external lobe and very low or low median saddle; ventrolateral saddle slightly asymmetric, rounded; adventive lobe V-shaped, acute, with flexed dorsal side and concavely incurved ventral flank.

Table 61. Conch ontogeny (Figs 44A, B, F-H) of Jerania jeranensis n. sp.

\begin{tabular}{|c|c|c|c|}
\hline$d m$ & conch shape & whorl cross section shape & aperture \\
\hline $2 \mathrm{~mm}$ & $\begin{array}{l}\text { thickly pachyconic; subinvolute } \\
\text { (ww/dm } \sim 0.75 ; \text { uw/dm } \sim 0.23 \text { ) }\end{array}$ & $\begin{array}{l}\text { moderately depressed; strongly embracing } \\
\text { (ww/wh } \sim 1.65 ; \text { IZR } \sim 0.40)\end{array}$ & $\begin{array}{l}\text { moderate } \\
(\text { WER } \sim 1.85)\end{array}$ \\
\hline $8 \mathrm{~mm}$ & $\begin{array}{l}\text { thinly pachyconic; subinvolute } \\
(\mathrm{ww} / \mathrm{dm}=0.60-0.68 ; \mathrm{uw} / \mathrm{dm}=0.15-0.20)\end{array}$ & $\begin{array}{l}\text { weakly depressed; strongly embracing } \\
(\text { ww/wh }=1.20-1.40 ; \mathrm{IZR}=0.40-0.45)\end{array}$ & $\begin{array}{l}\text { moderate } \\
(\text { WER } \sim 1.95)\end{array}$ \\
\hline $20 \mathrm{~mm}$ & $\begin{array}{l}\text { thinly discoidal; subinvolute } \\
(\mathrm{ww} / \mathrm{dm}=0.40-0.45 ; \mathrm{uw} / \mathrm{dm}=0.15-0.25)\end{array}$ & $\begin{array}{l}\text { weakly compressed to weakly depressed; strongly } \\
\text { embracing ( } w w / w h=0.85-1.20 ; \mathrm{IZR}=0.35-0.45 \text { ) }\end{array}$ & $\begin{array}{l}\text { low to moderate } \\
(\mathrm{WER}=1.70-2.00)\end{array}$ \\
\hline $30 \mathrm{~mm}$ & $\begin{array}{l}\text { thinly discoidal; subinvolute } \\
(w w / d m=0.35-0.42 ; u w / d m=0.15-0.22)\end{array}$ & $\begin{array}{l}\text { weakly compressed; strongly embracing } \\
(\text { ww/wh }=0.75-0.90 ; \text { IZR }=0.35-0.45)\end{array}$ & $\begin{array}{l}\text { moderate } \\
(\mathrm{WER}=1.80-2.00)\end{array}$ \\
\hline
\end{tabular}


Table 62. Conch dimensions (in $\mathrm{mm}$ ) and proportions for reference specimens of Jerania jeranensis n. sp.

\begin{tabular}{|c|c|c|c|c|c|c|c|c|c|c|}
\hline & $\mathrm{dm}$ & ww & wh & uw & ah & $w w / d m$ & ww/wh & $\mathrm{uw} / \mathrm{dm}$ & WER & IZR \\
\hline paratype MB.C.18788.1 & 38.9 & 13.6 & 16.6 & 9.0 & - & 0.35 & 0.82 & 0.23 & - & - \\
\hline holotype MB.C.18950.1 & 32.0 & 10.8 & 14.3 & 6.6 & 9.0 & 0.34 & 0.76 & 0.21 & 1.94 & 0.37 \\
\hline paratype MB.C.18726.1 & 30.5 & 12.9 & 15.0 & 4.4 & 8.0 & 0.42 & 0.86 & 0.14 & 1.84 & 0.47 \\
\hline paratype MB.C.18950.2 & 16.9 & 7.6 & 7.8 & 3.1 & 4.7 & 0.45 & 0.97 & 0.18 & 1.93 & 0.40 \\
\hline paratype MB.C.18950.3 & 9.8 & 5.3 & 4.3 & 2.0 & 2.4 & 0.54 & 1.24 & 0.20 & 1.73 & 0.45 \\
\hline
\end{tabular}

Table 63. Suture line proportions (Figs 44C-E) for Jerania jeranensis n. sp.

\begin{tabular}{lllllllll}
\hline specimen & at dm & EL w/d & EL/NLS & EL/AL & MS h & VLS w/h & remarks \\
\hline holotype MB.C.18950.1 & $30.5 \mathrm{~mm}$ & 0.72 & 1.18 & 1.44 & 0.32 & 0.61 & E lobe flanks strongly curved \\
paratype MB.C.18950.2 & $15.7 \mathrm{~mm}$ & 0.62 & 0.95 & 1.04 & 0.15 & 0.65 & M saddle comparatively low \\
paratype MB.C.18950.3 & $8.8 \mathrm{~mm}$ & 0.57 & 0.74 & 1.29 & 0.20 & 0.78 & VL saddle broadly rounded \\
\hline
\end{tabular}
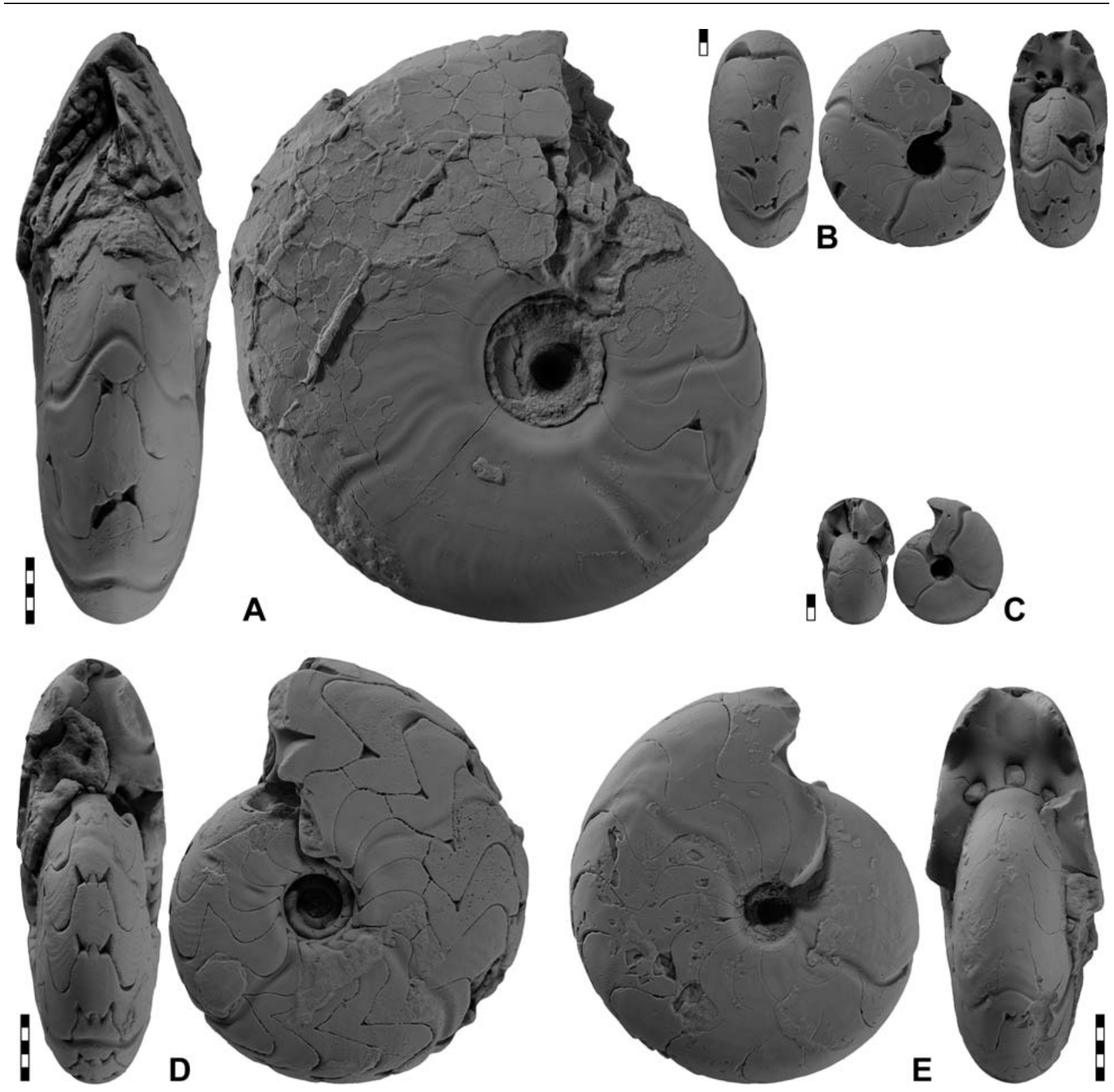

Figure 43. Jerania jeranensis $n$. $\mathrm{sp}$.; all $\times 2$. A. Paratype MB.C.18788.1 from locality MOU-B. B. Paratype MB.C.18950.2 from locality MOU-E07. C. Paratype MB.C.18950.3 from locality MOU-E07. D. Holotype MB.C.18950.1 from locality MOU-E07. E. Paratype MB.C.18726.1 from locality A-264. 

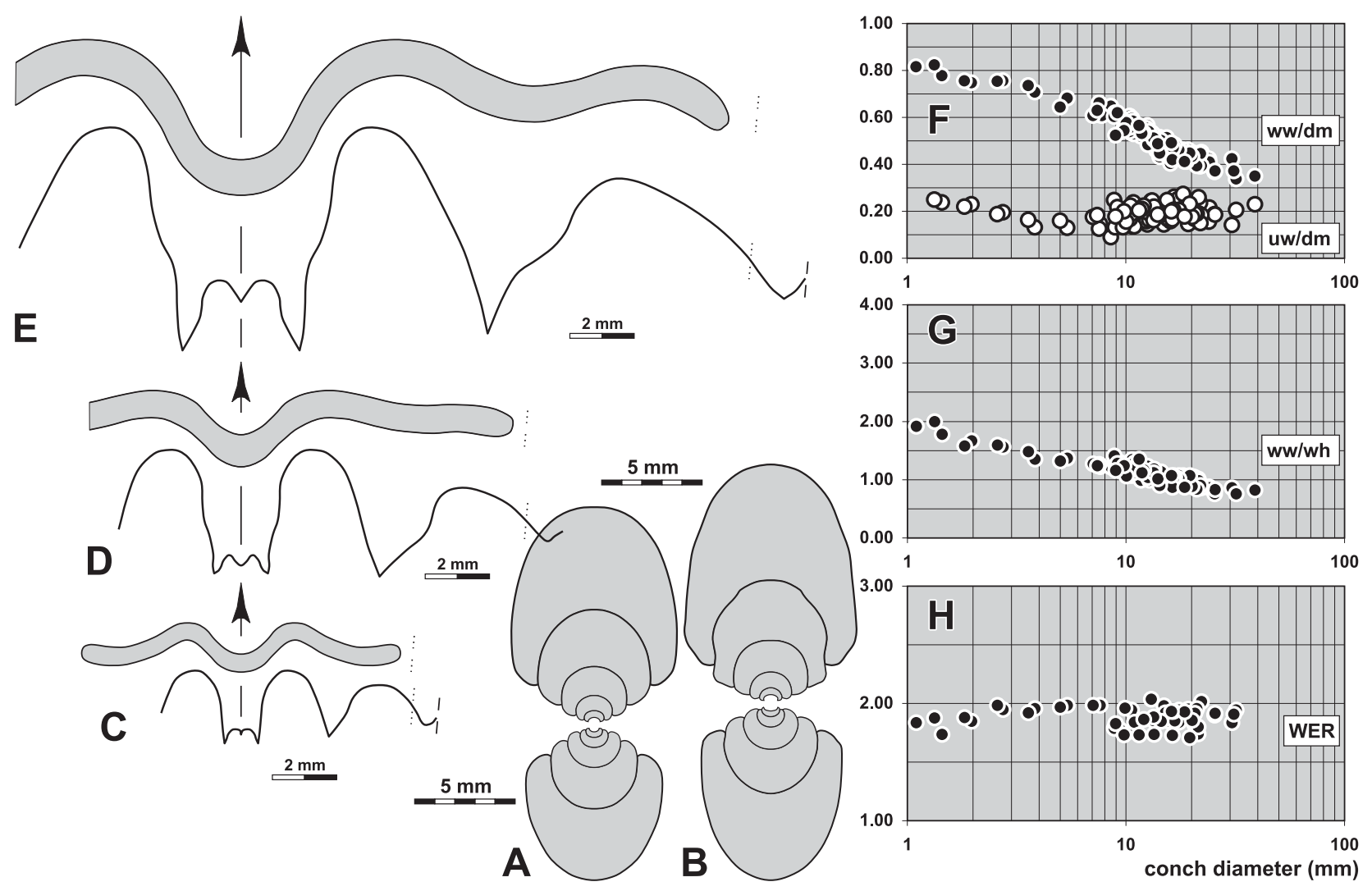

Figure 44. Jerania jeranensis n. sp. A. Cross section of paratype MB.C. 18950.4 from locality MOU-E07; $\times 2.5$. B. Cross section of paratype MB.C.18869.1 from locality MOU-D1; ×2.5. C. Suture line and constriction of paratype MB.C.18950.3 from locality MOU-E07, at $8.8 \mathrm{~mm} \mathrm{dm}, 5.7 \mathrm{~mm} w w, 4.7 \mathrm{~mm}$ wh; $\times 4.0$. D. Suture line and constriction of paratype MB.C.18950.2 from locality MOU-E07, at $15.7 \mathrm{~mm} \mathrm{dm}, 7.6 \mathrm{~mm}$ ww, $8.3 \mathrm{~mm}$ wh; $\times 4.0$. E. Suture line and constriction of holotype MB.C.18950.1 from locality MOU-E07, at $30.5 \mathrm{~mm} \mathrm{dm}, 10.8 \mathrm{~mm}$ ww, $14.9 \mathrm{~mm}$ wh; $\times 4.0$. F-H. Ontogenetic development of the conch width index (ww/dm), umbilical width index (uw/dm), whorl width index (ww/wh), and whorl expansion rate (WER) of all available specimens.

\section{Jerania sicilicula $\mathbf{n}$. sp.}

Figures 45, 46

Derivation of name. From Latin sicilicula $=$ a small sickle, because of the constrictions.

Holotype. Specimen MB.C.18870.1, illustrated in Figure 45B.

Type locality and horizon. Oued Temertasset, locality and sample MOU-D1 (Mouydir, South Algeria); upper Pericyclus-Progoniatites Assemblage. Material. 199 specimens, conch diameter up to $33 \mathrm{~mm}$.

Diagnosis. Jerania with a thickly pachyconic conch in the early juvenile stage, continuously becoming more slender and being thinly discoidal at $30 \mathrm{~mm} \mathrm{dm}$; conch subinvolute in the juvenile stage up to $5 \mathrm{~mm} \mathrm{dm}$, thereafter involute; umbilicus funnel-shaped with subangular margin and oblique umbilical wall; aperture moderate except for low early juvenile stage. Steinkern with biconvex constrictions that extend with a shallow lateral sinus, a rather prominent ventrolateral projection, and deep ventral sinus. Suture line with narrow, V-shaped external lobe with almost straight flanks and very low median saddle; ventrolateral saddle slightly asymmetric, broadly rounded; adventive lobe rather wide and V-shaped, with almost straight flanks.

Table 64. Conch ontogeny (Figs 46A-C, F-H) of Jerania sicilicula n. sp.

\begin{tabular}{|c|c|c|c|}
\hline $\mathrm{dm}$ & conch shape & whorl cross section shape & aperture \\
\hline $2 \mathrm{~mm}$ & $\begin{array}{l}\text { thickly pachyconic; subinvolute } \\
\text { (ww/dm } \sim 0.75 ; \text { uw/dm } \sim 0.21 \text { ) }\end{array}$ & $\begin{array}{l}\text { moderately depressed; very strongly embracing } \\
\text { (ww/wh } \sim 1.65 ; \text { IZR } \sim 0.50 \text { ) }\end{array}$ & $\begin{array}{l}\text { low } \\
\text { (WER 1.70) }\end{array}$ \\
\hline $8 \mathrm{~mm}$ & $\begin{array}{l}\text { thickly discoidal; involute } \\
\text { (ww/dm }=0.55-0.60 ; \mathrm{u} / \mathrm{dm}=0.10-0.15 \text { ) }\end{array}$ & $\begin{array}{l}\text { weakly depressed; very strongly embracing } \\
\text { (ww/wh }=1.00-1.20 ; \mathrm{IZR}=0.45-0.50)\end{array}$ & $\begin{array}{l}\text { moderate } \\
(\text { WER }=1.80-2.00)\end{array}$ \\
\hline $20 \mathrm{~mm}$ & $\begin{array}{l}\text { thinly discoidal; involute } \\
\text { (ww/dm }=0.40-0.45 ; \mathrm{uw} / \mathrm{dm}=0.10-0.15)\end{array}$ & $\begin{array}{l}\text { weakly compressed; very strongly embracing } \\
(\mathrm{ww} / \mathrm{wh}=0.80-1.00 ; \mathrm{IZR}=0.45-0.50)\end{array}$ & $\begin{array}{l}\text { moderate } \\
(\mathrm{WER}=1.80-2.00)\end{array}$ \\
\hline $30 \mathrm{~mm}$ & $\begin{array}{l}\text { thinly discoidal; involute } \\
(\mathrm{w} w / \mathrm{dm}=0.36-0.43 ; \mathrm{uw} / \mathrm{dm}=0.10-0.15)\end{array}$ & $\begin{array}{l}\text { weakly compressed; very strongly embracing } \\
(\mathrm{ww} / \mathrm{wh}=0.70-0.80 ; \mathrm{IZR}=0.45-0.50)\end{array}$ & $\begin{array}{l}\text { moderate } \\
(\text { WER } \sim 1.90)\end{array}$ \\
\hline
\end{tabular}



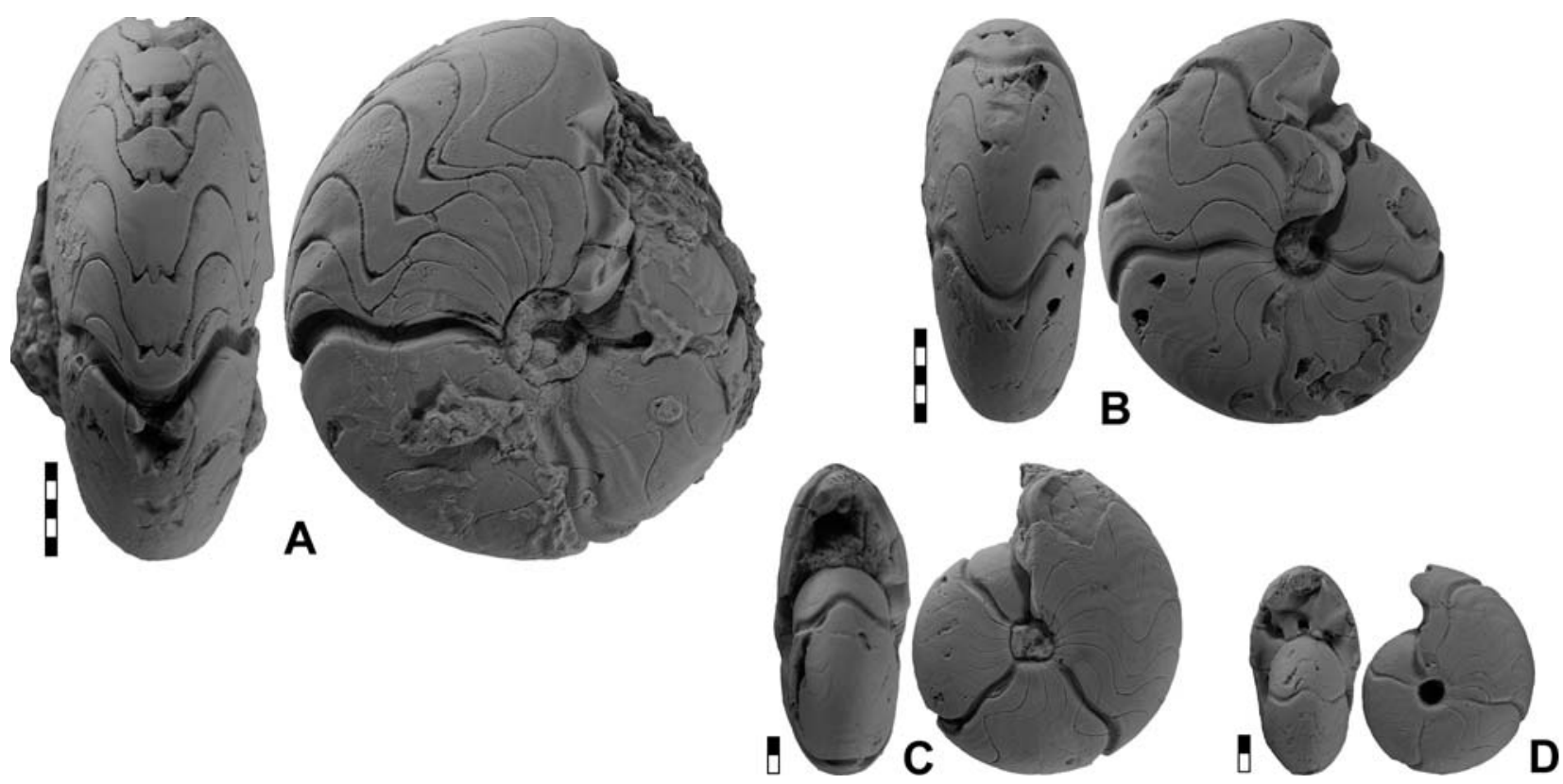

Figure 45. Jerania sicilicula n. sp.; all $\times 2$. A. Paratype MB.C.18894.1 from locality MOU-D2. B. Holotype MB.C.18870.1 from locality MOU-D1. C. Paratype MB.C.18951.1 from locality MOU-E07. D. Paratype MB.C.18951.2 from locality MOU-E07.
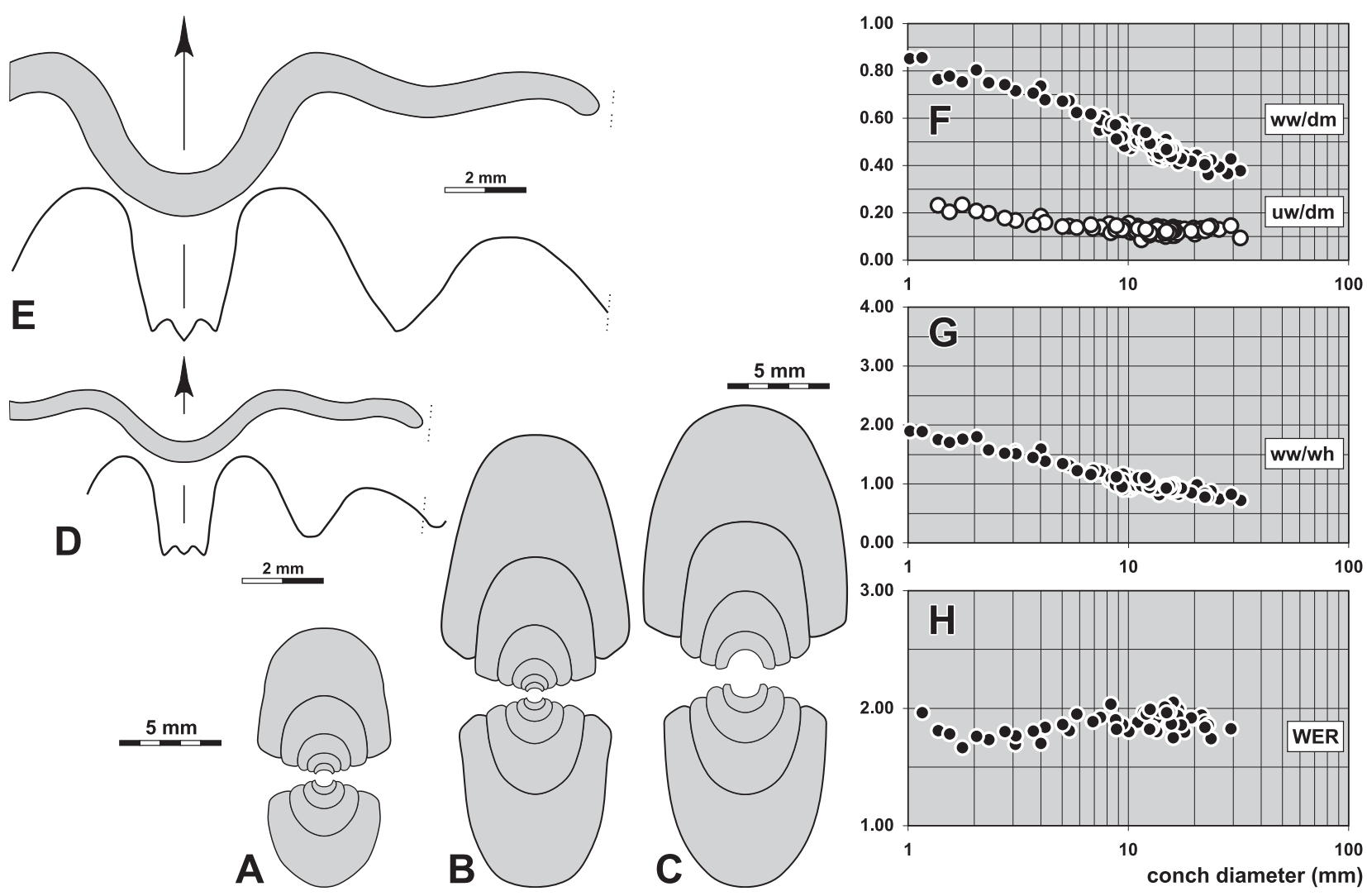

Figure 46. Jerania sicilicula n. sp. A. Cross section of paratype MB.C.18951.3 from locality MOU-E07; $\times 2.5$. B. Cross section of paratype MB.C.18951.4 from locality MOU-E07; ×2.5. C. Cross section of paratype MB.C.18951.5 from locality MOU-E07; $\times 2.5$. D. Suture line and constriction of paratype MB.C.18951.2 from locality MOU-E07, at $10.4 \mathrm{~mm} \mathrm{dm}, 5.4 \mathrm{~mm} \mathrm{ww}, 5.5 \mathrm{~mm}$ wh; $\times$ 4.0. E. Suture line and constriction of paratype MB.C.18951.6 from locality MOU-E07, at $17.1 \mathrm{~mm} \mathrm{dm,} 7.6 \mathrm{~mm}$ ww, $9.4 \mathrm{~mm}$ wh; $\times 4.0$. F-H. Ontogenetic development of the conch width index (ww/dm), umbilical width index (uw/dm), whorl width index (ww/wh), and whorl expansion rate (WER) of all available specimens. 
Table 65. Conch dimensions (in $\mathrm{mm}$ ) and proportions for reference specimens of Jerania sicilicula $\mathrm{n}$. sp.

\begin{tabular}{|c|c|c|c|c|c|c|c|c|c|c|}
\hline & $\mathrm{dm}$ & ww & wh & uw & ah & $w w / d m$ & ww/wh & $\mathrm{uw} / \mathrm{dm}$ & WER & IZR \\
\hline paratype MB.C.18894.1 & 29.3 & 12.5 & 15.2 & 4.3 & 7.9 & 0.43 & 0.82 & 0.15 & 1.88 & 0.48 \\
\hline holotype MB.C.18870.1 & 21.5 & 8.8 & 10.5 & 2.9 & 6.1 & 0.41 & 0.84 & 0.13 & 1.94 & 0.42 \\
\hline paratype MB.C.18951.1 & 16.9 & 6.9 & 8.4 & 2.2 & 4.8 & 0.41 & 0.82 & 0.13 & 1.99 & 0.42 \\
\hline paratype MB.C.18951.2 & 11.1 & 5.6 & 5.3 & 1.6 & 3.0 & 0.51 & 1.06 & 0.14 & 1.88 & 0.43 \\
\hline
\end{tabular}

Table 66. Suture line proportions (Figs 46D, E) for Jerania sicilicula n. sp.

\begin{tabular}{llllllll}
\hline specimen & at dm & EL w/d & EL/NLS & EL/AL & MS h & VLS w/h & remarks \\
\hline paratype MB.C.18951.6 & $17.1 \mathrm{~mm}$ & 0.69 & 0.85 & 0.88 & 0.08 & 0.81 & A lobe rounded at base \\
paratype MB.C.18951.2 & $10.4 \mathrm{~mm}$ & 0.58 & 0.77 & 0.88 & 0.09 & 0.75 & \\
\hline
\end{tabular}

\section{Jerania pusillens n. sp.}

Figures 47, 48

Derivation of name. From Latin pusilla $=$ small and lens $=$ lentil, because of the conch shape.

Holotype. Specimen MB.C.18871.1, illustrated in Figure 47B.

Type locality and horizon. Oued Temertasset, locality and sample MOU-D1 (Mouydir, South Algeria); upper Pericyclus-Progoniatites Assemblage.

Material. 26 specimens, conch diameter up to $20 \mathrm{~mm}$.

Diagnosis. Jerania with very small, thickly pachyconic conch in the early juvenile stage, rapidly becoming more slender and being thinly discoidal at $16 \mathrm{~mm} \mathrm{dm}$; conch subinvolute in the early juvenile stage up to $2 \mathrm{~mm} \mathrm{dm}$, thereafter involute; umbilicus funnel-shaped with narrowly rounded margin and oblique umbilical wall; aperture moderate except for low early juvenile stage. Steinkern with slightly biconvex constrictions that extend with a very shallow lateral sinus, a low ventrolateral projection, and moderately deep ventral sinus. Suture line with narrow, V-shaped external lobe and very low median saddle; ventrolateral saddle slightly asymmetric, rounded; adventive lobe V-shaped, acute, with almost straight flanks.

Table 67. Conch ontogeny (Figs 48A, C-E) of Jerania pusillens $\mathrm{n}$. sp.

\begin{tabular}{|c|c|c|c|}
\hline$d m$ & conch shape & whorl cross section shape & aperture \\
\hline $2 \mathrm{~mm}$ & $\begin{array}{l}\text { thickly pachyconic; involute } \\
\text { (ww/dm } \sim 0.75 ; \text { uw/dm } \sim 0.12 \text { ) }\end{array}$ & $\begin{array}{l}\text { weakly depressed; very strongly embracing } \\
\text { (ww/wh } \sim 1.45 ; \text { IZR } \sim 0.55 \text { ) }\end{array}$ & $\begin{array}{l}\text { low } \\
(\text { WER } \sim 1.70)\end{array}$ \\
\hline $8 \mathrm{~mm}$ & $\begin{array}{l}\text { thinly discoidal; involute } \\
(\mathrm{ww} / \mathrm{dm}=0.44-0.50 ; \mathrm{uw} / \mathrm{dm}=0.05-0.15 \text { ) }\end{array}$ & $\begin{array}{l}\text { weakly compressed; very strongly embracing } \\
\text { (ww/wh }=0.85-1.00 ; \mathrm{IZR}=0.45-0.55)\end{array}$ & $\begin{array}{l}\text { moderate } \\
(\mathrm{WER}=1.75-1.90)\end{array}$ \\
\hline $16 \mathrm{~mm}$ & $\begin{array}{l}\text { thinly discoidal; involute } \\
\text { (ww/dm } \sim 0.36 ; \text { uw/dm } \sim 0.10 \text { ) }\end{array}$ & $\begin{array}{l}\text { weakly compressed; very strongly embracing } \\
\text { (ww/wh } \sim 0.75 ; \mathrm{IZR} \sim 0.50 \text { ) }\end{array}$ & $\begin{array}{l}\text { moderate } \\
(\mathrm{WER}=1.75-1.85)\end{array}$ \\
\hline
\end{tabular}

Table 68. Conch dimensions (in $\mathrm{mm}$ ) and proportions for reference specimens of Jerania pusillens $\mathrm{n}$. $\mathrm{sp}$.

\begin{tabular}{|c|c|c|c|c|c|c|c|c|c|c|}
\hline & $\mathrm{dm}$ & ww & wh & uw & ah & $w w / d m$ & ww/wh & $\mathrm{uw} / \mathrm{dm}$ & WER & IZR \\
\hline paratype MB.C.18764.1 & 12.5 & 5.0 & 6.6 & 1.6 & 3.5 & 0.40 & 0.75 & 0.13 & 1.93 & 0.47 \\
\hline holotype MB.C.18871.1 & 11.2 & 4.9 & 5.5 & 1.4 & 2.8 & 0.43 & 0.88 & 0.13 & 1.78 & 0.49 \\
\hline paratype MB.C.18871.2 & 8.3 & 3.7 & 4.3 & 0.5 & 2.2 & 0.44 & 0.87 & 0.06 & 1.82 & 0.49 \\
\hline
\end{tabular}


Table 69. Suture line proportions (Fig. 48B) for Jerania pusillens n. sp.

\begin{tabular}{llllllll}
\hline specimen & at dm & EL w/d & EL/VLS & EL/AL & MS h & VLS w/h & remarks \\
\hline holotype MB.C.18871.1 & $10.6 \mathrm{~mm}$ & 0.56 & 0.67 & 1.25 & 0.14 & 0.83 \\
\hline
\end{tabular}

Discussion. Jerania pusillens is mainly distinguished from the other species of the genus by its small lenticular conch. Only J. subvexa has a very similar conch, but differs in the very shallow, blunt adventive lobe.
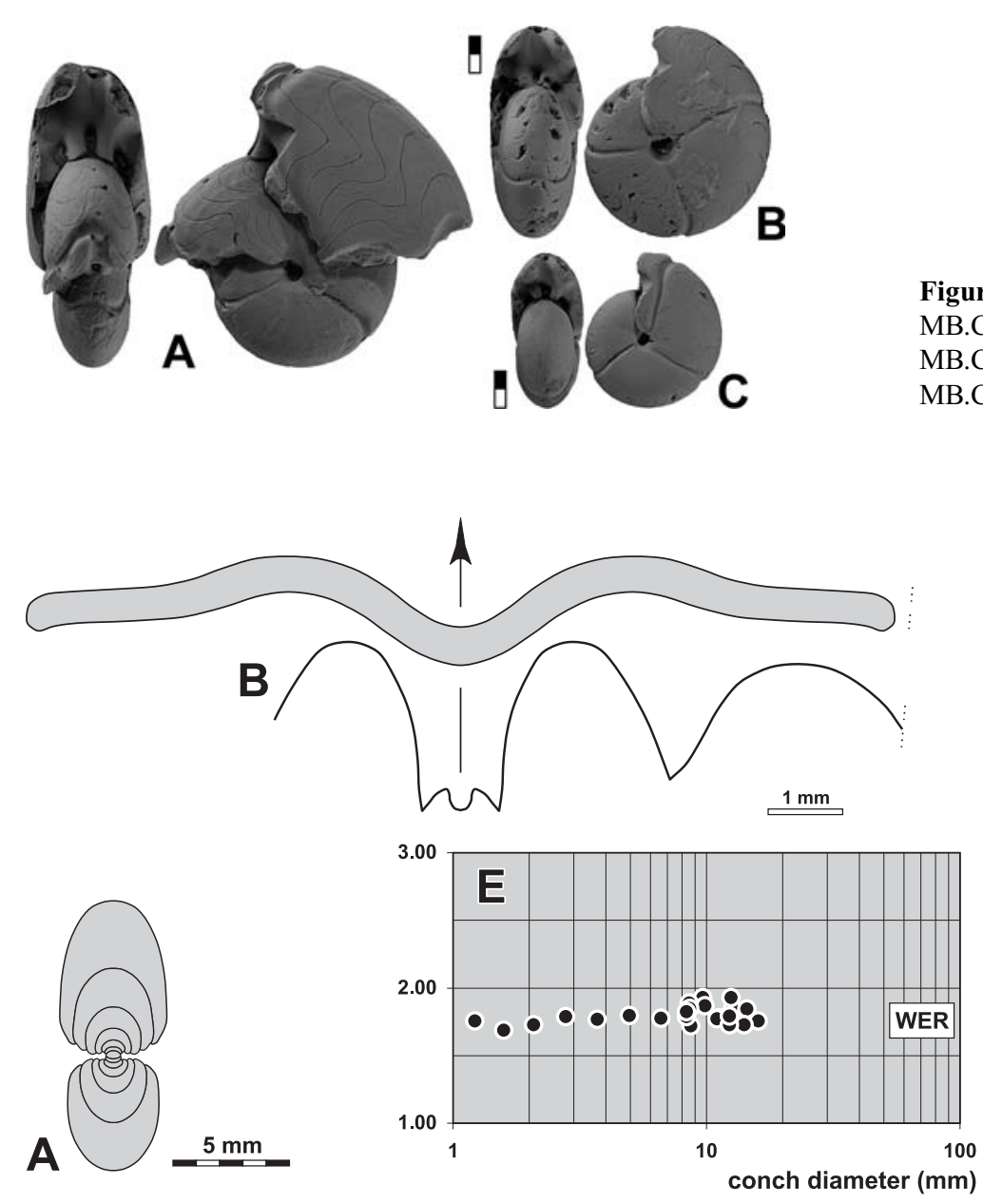

Figure 47. Jerania pusillens n. sp.; all $\times 2$. A. Paratype MB.C.18764.1 from locality MOU-A. B. Holotype MB.C.18871.1 from locality MOU-D1. C. Paratype MB.C.18871.2 from locality MOU-D1.

Figure 48. Jerania pusillens n. sp. A. Cross section of paratype MB.C.18871.3 from locality MOU-D1; $\times 2.5$. B. Suture line and constriction of holotype MB.C.18871.1 from locality MOU-D1, at $10.6 \mathrm{~mm} \mathrm{dm}, 5.0 \mathrm{~mm} w w, 6.0 \mathrm{~mm}$ wh; $\times 8.0$. C-E. Ontogenetic development of the conch width index (ww/dm), umbilical width index (uw/dm), whorl width index (ww/wh), and whorl expansion rate (WER) of all available specimens.

\section{Jerania persimilis n. sp.}

Figures 49, 50

Derivation of name. From Latin persimilis = very similar, because of the resemblance with the type species.

Holotype. Specimen MB.C.18940.1, illustrated in Figure 49A.

Type locality and horizon. Oued Temertasset, locality and sample MOU-E06 (Mouydir, South Algeria); upper Pericyclus-Progoniatites Assemblage. Material. 71 specimens, conch diameter up to $37 \mathrm{~mm}$.

Diagnosis. Jerania with thickly pachyconic conch in the early juvenile stage, almost continuously becoming more slender and being thinly discoidal at $20 \mathrm{~mm} \mathrm{dm}$; conch subinvolute throughout ontogeny; umbilicus funnel-shaped with subangular margin and oblique umbilical wall; aperture moderate throughout ontogeny except for a low early juvenile aperture. Steinkern with biconvex constrictions with shallow lateral sinus and deep ventral sinus; week riblets between the constrictions. Suture line with very narrow external lobe with subparallel flanks and low median saddle; ventrolateral saddle slightly asymmetric, broadly rounded; adventive lobe V-shaped. 
Table 70. Conch ontogeny (Figs 50A, D-F) of Jerania persimilis n. sp.

\begin{tabular}{|c|c|c|c|}
\hline$d m$ & conch shape & whorl cross section shape & aperture \\
\hline $2 \mathrm{~mm}$ & $\begin{array}{l}\text { thinly pachyconic; subinvolute } \\
\text { (ww/dm } \sim 0.70 ; \text { uw/dm } \sim 0.25 \text { ) }\end{array}$ & $\begin{array}{l}\text { moderately depressed; very strongly embracing } \\
\text { (ww/wh } \sim 1.75 ; \text { IZR } \sim 0.45 \text { ) }\end{array}$ & $\begin{array}{l}\text { low } \\
\text { (WER 1.65) }\end{array}$ \\
\hline $8 \mathrm{~mm}$ & $\begin{array}{l}\text { thinly pachyconic; subinvolute } \\
\text { (ww/dm } \sim 0.60 ; \text { uw/dm } \sim 0.18 \text { ) }\end{array}$ & $\begin{array}{l}\text { weakly depressed; very strongly embracing } \\
\text { (ww/wh } \sim 1.30 \text {; IZR } \sim 0.45 \text { ) }\end{array}$ & $\begin{array}{l}\text { moderate } \\
(\text { WER } \sim 1.80)\end{array}$ \\
\hline $20 \mathrm{~mm}$ & $\begin{array}{l}\text { thinly discoidal; subinvolute } \\
\text { (ww/dm }=0.40-0.50 ; u w / d m=0.18-0.25)\end{array}$ & $\begin{array}{l}\text { weakly compressed; strongly embracing } \\
(\mathrm{ww} / \mathrm{wh}=0.95-1.00 ; \mathrm{IZR}=0.40-0.45)\end{array}$ & $\begin{array}{l}\text { moderate } \\
(\text { WER }=1.80-1.90)\end{array}$ \\
\hline $30 \mathrm{~mm}$ & $\begin{array}{l}\text { thinly discoidal; subinvolute } \\
(w w / d m=0.36-0.40 ; \text { uw } / \mathrm{dm}=0.18-0.25)\end{array}$ & $\begin{array}{l}\text { weakly compressed; strongly embracing } \\
(\mathrm{ww} / \mathrm{wh}=0.75-1.00 ; \mathrm{IZR}=0.40-0.45)\end{array}$ & $\begin{array}{l}\text { moderate } \\
(\mathrm{WER}=1.80-1.90)\end{array}$ \\
\hline
\end{tabular}

Table 71. Conch dimensions (in $\mathrm{mm}$ ) and proportions for reference specimens of Jerania persimilis n. sp.

\begin{tabular}{lccccccccccc}
\hline & $\mathrm{dm}$ & ww & wh & uw & ah & ww/dm & ww/wh & uw/dm & WER & IZR \\
\hline paratype MB.C.18790.1 & 33.1 & 11.8 & 15.4 & 6.9 & 8.0 & 0.36 & 0.77 & 0.21 & 1.73 & 0.48 \\
holotype MB.C.18940.1 & 32.5 & 12.0 & 13.9 & 7.2 & 8.3 & 0.37 & 0.86 & 0.22 & 1.80 & 0.40 \\
paratype MB.C.18872.2 & 28.4 & 11.4 & 13.0 & 5.9 & 7.4 & 0.40 & 0.88 & 0.21 & 1.83 & 0.43 \\
paratype MB.C.18749.1 & 23.5 & 10.4 & 10.5 & 4.4 & 6.2 & 0.44 & 0.99 & 0.19 & 1.85 & 0.41 \\
paratype MB.C.18872.1 & 20.4 & 9.4 & 9.2 & 4.2 & 5.1 & 0.46 & 1.02 & 0.21 & 1.78 & 0.44 \\
\hline
\end{tabular}
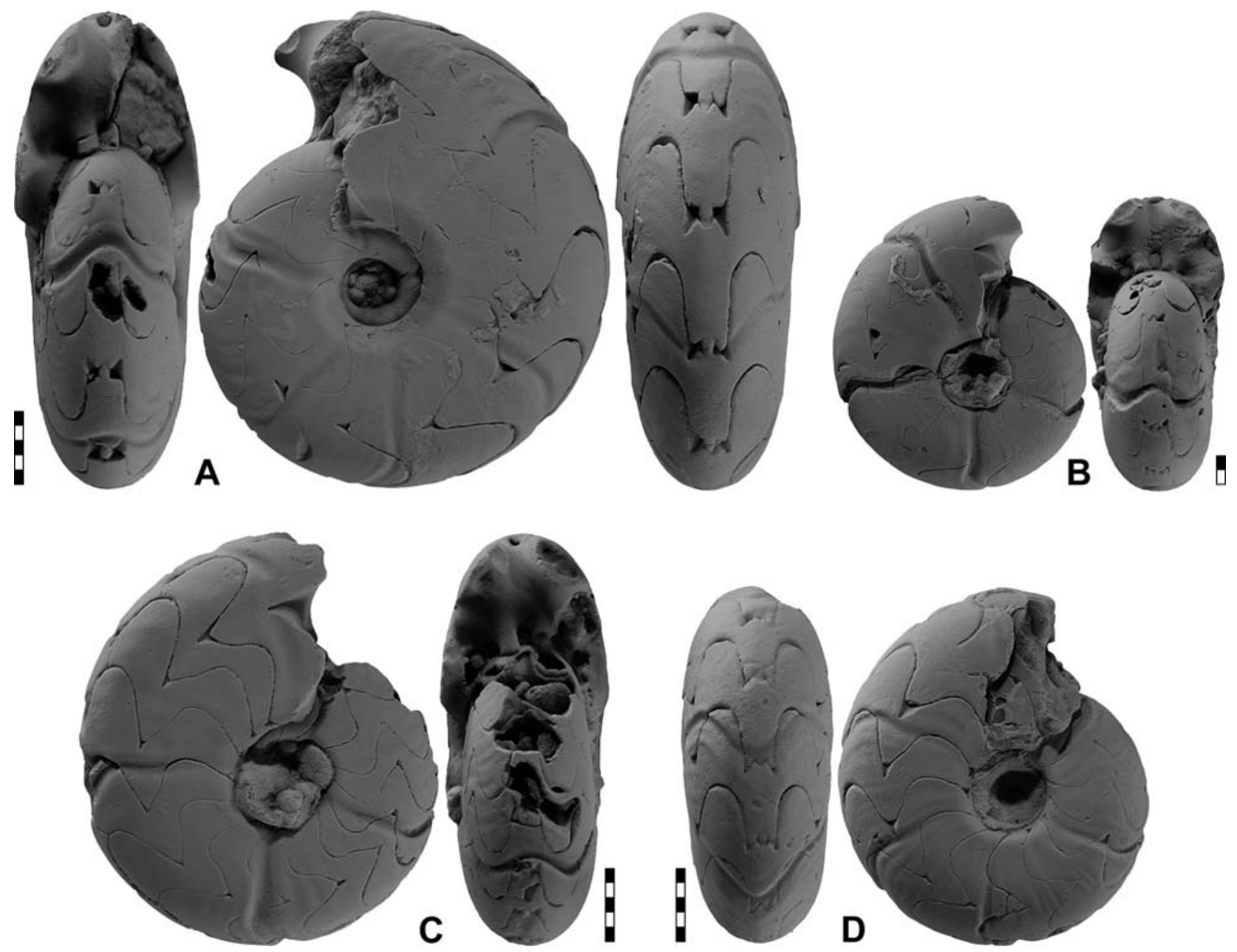

Figure 49. Jerania persimilis n. sp.; all $\times 2$. A. Holotype MB.C.18940.1 from locality MOU-E06. B. Paratype MB.C.18872.1 from locality MOU-D1. C. Paratype MB.C.18872.2 from locality MOU-D1. D. Paratype MB.C.18749.1 from locality A321. 
Table 72. Suture line proportions (Figs 50B, C) for Jerania persimilis n. sp.

\begin{tabular}{llllllll}
\hline specimen & at dm & EL w/d & EL/VLS & EL/AL & MS h & VLS w/h & remarks \\
\hline paratype MB.C.18790.2 & $32.9 \mathrm{~mm}$ & 0.48 & 0.87 & 1.12 & 0.23 & 0.55 & A lobe asymmetric \\
paratype MB.C.18790.1 & $20.1 \mathrm{~mm}$ & 0.49 & 0.59 & 1.35 & 0.20 & 0.83 & A lobe symmetric V-shaped \\
\hline
\end{tabular}

Discussion. Jerania persimilis is very similar to J. jeranensis, and the two species are hard to separate solely on the basis of conch morphology. Only the suture line provides clear distinguishing characters, with J. jeranensis possessing a much wider, V-shaped external lobe with curved flanks, in contrast to the much narrower external lobe with subparallel flanks in $J$. persimilis.

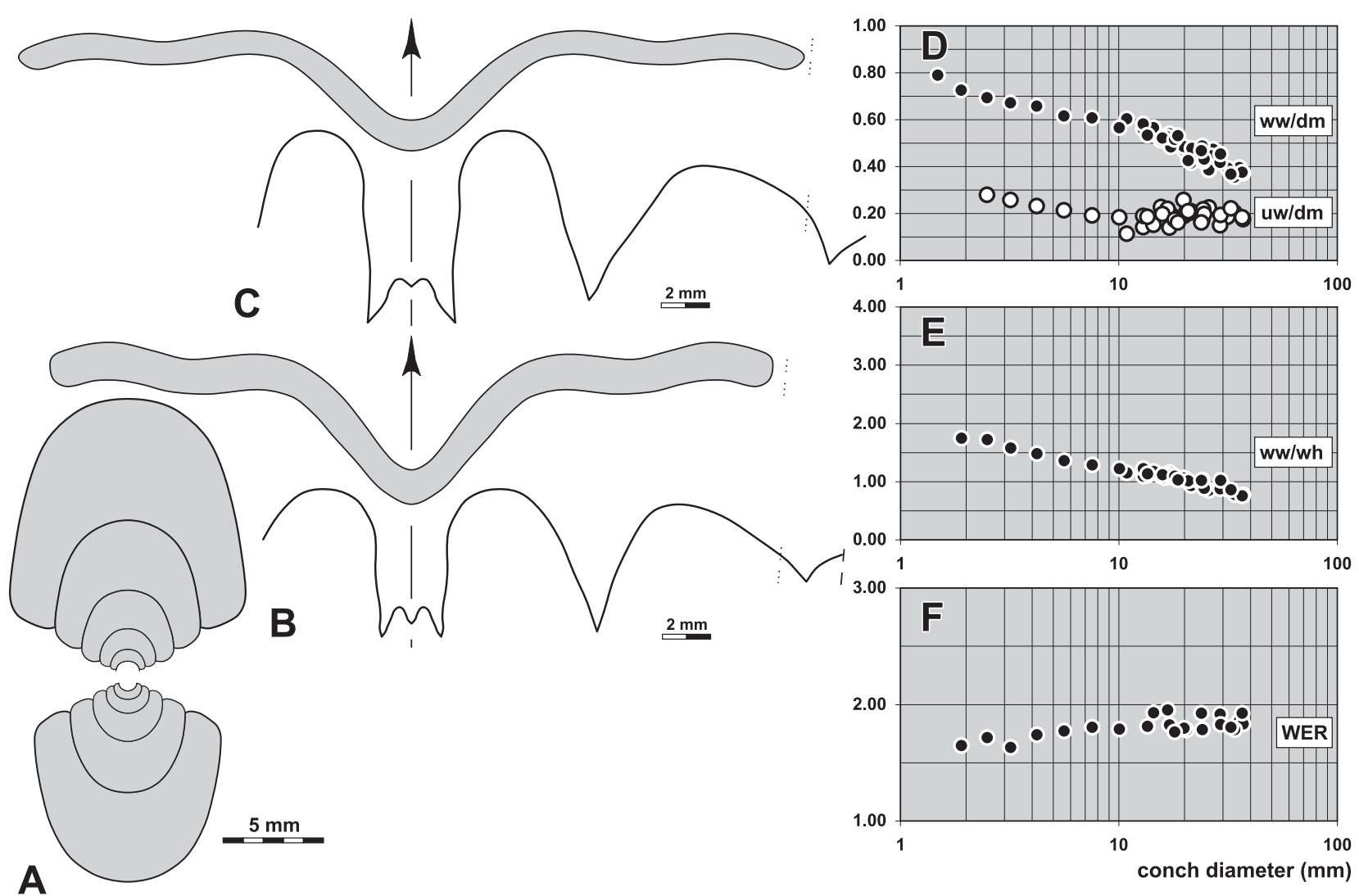

Figure 50. Jerania persimilis n. sp. A. Cross section of paratype MB.C.18896 from locality MOU-D2; $\times 2.5$. B. Suture line and constriction of paratype MB.C.18790.1 from locality MOU-B0, at $31.8 \mathrm{~mm} \mathrm{dm}, 11.7 \mathrm{~mm} w w, 15.4 \mathrm{~mm}$ wh; $\times 3.0$. C. Suture line and constriction of paratype MB.C.18790.2 from locality MOU-B0, at $34.2 \mathrm{~mm} \mathrm{dm}, 12.4 \mathrm{~mm} w w, 16.0 \mathrm{~mm}$ wh; $\times 3.0$. D-F. Ontogenetic development of the conch width index (ww/dm), umbilical width index (uw/dm), whorl width index (ww/wh), and whorl expansion rate (WER) of all available specimens.

\section{Jerania subvexa n. sp.}

Figures 51, 52

Derivation of name. From Latin subvexa = oblique, because of the umbilical wall.

Holotype. Specimen MB.C.19027.1, illustrated in Figure 51C.

Type locality and horizon. Oued Temertasset, locality and sample MOU-V (Mouydir, South Algeria); lower part of the Pericyclus-Progoniatites Assemblage.

Material. 180 specimens, conch diameter up to $24 \mathrm{~mm}$.

Diagnosis. Jerania with small, thickly pachyconic conch in the early juvenile stage, rapidly becoming more slender and being thinly discoidal at $10 \mathrm{~mm} \mathrm{dm}$; conch subinvolute in the early juvenile stage up to $2 \mathrm{~mm} \mathrm{dm}$, thereafter involute with a trend towards slight re-opening of the umbilicus above $8 \mathrm{~mm} \mathrm{dm}$; umbilicus funnel-shaped with narrowly rounded margin and oblique umbilical wall; aperture moderate except for low early juvenile stage. Steinkern with slightly biconvex constrictions that extend with a very shallow lateral sinus, a low ventrolateral projection, and moderately deep ventral sinus. Suture line with narrow, V-shaped external lobe and very low median saddle; ventrolateral saddle slightly asymmetric, rounded; adventive lobe very shallow, V-shaped, blunt at its base, with convex flanks. 
Table 73. Conch ontogeny (Figs 52A-C, G-I) of Jerania subvexa n. sp.

\begin{tabular}{llll}
\hline $\mathrm{dm}$ & conch shape & whorl cross section shape & aperture \\
\hline $2 \mathrm{~mm}$ & thickly pachyconic; involute & weakly depressed; very strongly embracing & moderate \\
& $($ ww/dm $\sim 0.75 ;$ uw/dm $=0.10-0.15)$ & $($ ww/wh $\sim 1.45 ;$ IZR $\sim 0.50)$ & $($ WER $\sim 1.80)$ \\
$8 \mathrm{~mm}$ & thickly discoidal; involute & weakly compressed; very strongly embracing & moderate \\
& $($ ww/dm $=0.50-0.55 ;$ uw $/ \mathrm{dm}=0.08-0.12)$ & $($ ww/wh $=0.90-1.00 ;$ IZR $=0.45-0.55)$ & $($ WER $=1.75-1.90)$ \\
$20 \mathrm{~mm}$ & thinly discoidal; involute & weakly compressed; very strongly embracing & moderate \\
& $($ ww/dm $\sim 0.36 ;$ uw/dm $\sim 0.12)$ & $($ ww/wh $\sim 0.75 ;$ IZR $\sim 0.50)$ & $($ WER $\sim 1.75)$ \\
\hline
\end{tabular}

Table 74. Conch dimensions (in $\mathrm{mm}$ ) and proportions for reference specimens of Jerania subvexa n. sp.

\begin{tabular}{lccccccccccc}
\hline & $\mathrm{dm}$ & ww & wh & uw & ah & ww/dm & ww/wh & uw/dm & WER & IZR \\
\hline paratype MB.C.19027.2 & 23.6 & 8.0 & 11.5 & 3.2 & 5.8 & 0.34 & 0.69 & 0.14 & 1.76 & 0.50 \\
holotype MB.C.19027.1 & 20.3 & 7.5 & 9.6 & 2.4 & 4.9 & 0.37 & 0.78 & 0.12 & 1.75 & 0.49 \\
paratype MB.C.19027.4 & 15.1 & 5.9 & 7.2 & 2.2 & 3.8 & 0.39 & 0.82 & 0.14 & 1.78 & 0.48 \\
paratype MB.C.19027.3 & 12.3 & 5.2 & 6.1 & 1.4 & 3.0 & 0.42 & 0.85 & 0.11 & 1.75 & 0.50 \\
\hline
\end{tabular}

Table 75. Suture line proportions (Figs 52D-F) for Jerania subvexa n. sp.

\begin{tabular}{llllllll}
\hline specimen & at dm & EL w/d & EL/NLS & EL/AL & MS h & VLS w/h & remarks \\
\hline holotype MB.C.19027.1 & $19.6 \mathrm{~mm}$ & 0.51 & 0.53 & 0.75 & 0.15 & 0.96 & A lobe much shorter than E lobe \\
paratype MB.C.19027.4 & $14.7 \mathrm{~mm}$ & 0.60 & 0.63 & 0.94 & 0.13 & 0.96 & \\
paratype MB.C.19027.3 & $12.0 \mathrm{~mm}$ & 0.55 & 0.55 & 0.80 & 0.13 & 0.99 & E lobe very narrow at the base \\
\hline
\end{tabular}

Discussion. Jerania subvexa is easily distinguished from all the other species of the genus by its very shallow, blunt adventive lobe. In the conch shape, J. pusillens is very similar to $J$. subvexa making it very hard to separate them with regards to this character.

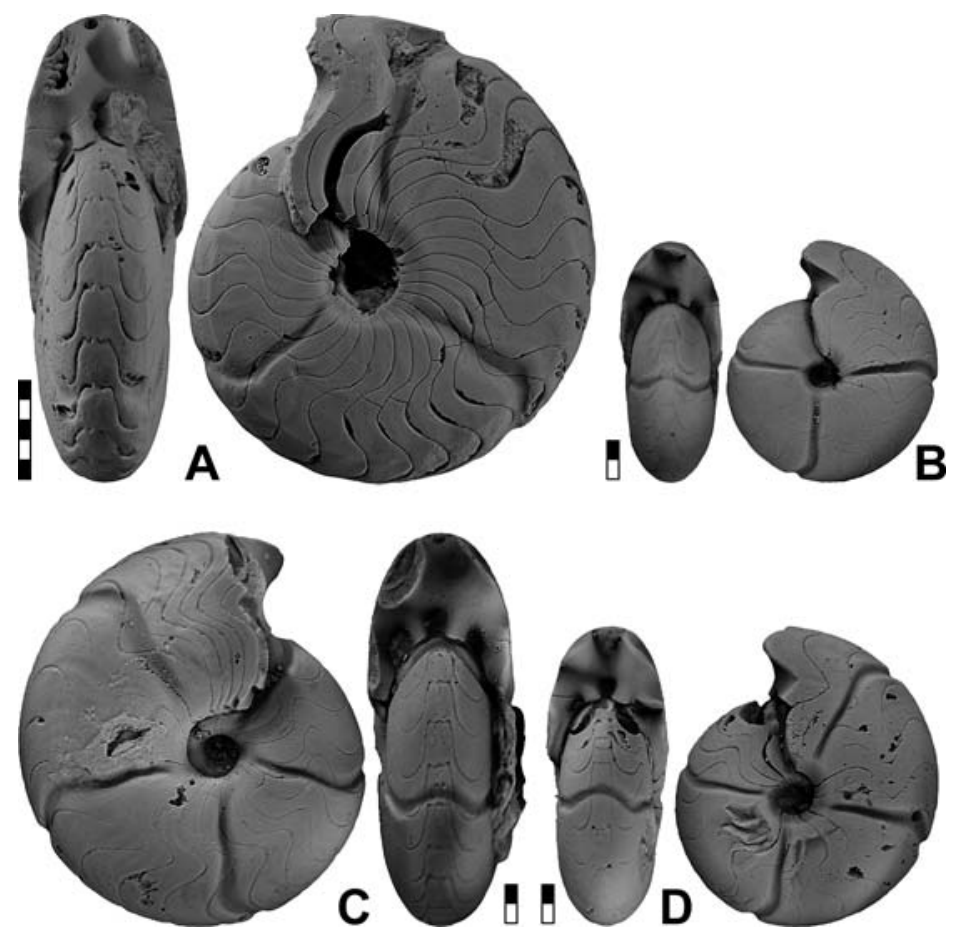

Figure 51. Jerania subvexa $\mathrm{n}$. sp. from locality MOUV; all $\times 2$. A. Paratype MB.C.19027.2. B. Paratype MB.C.19027.3. C. Holotype MB.C.19027.1. D. Paratype MB.C.19027.4. 

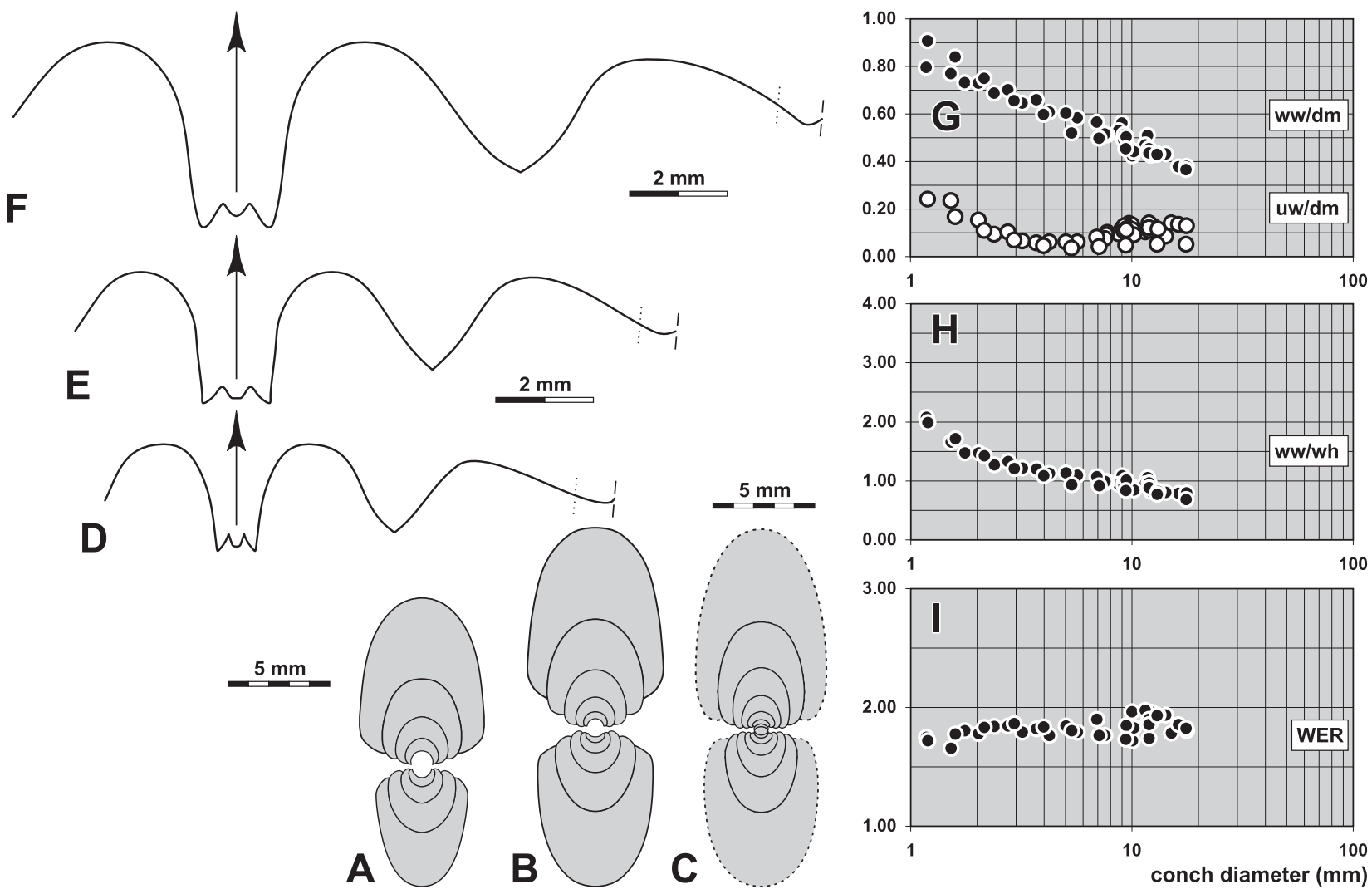

Figure 52. Jerania subvexa $\mathrm{n}$. sp. from locality MOU-V. A. Cross section of paratype MB.C.19027.5; $\times 2.5$. B. Cross section of paratype MB.C.19027.6; $\times 2.5$. C. Cross section of paratype MB.C.19027.7; $\times 2.5$. D. Suture line of paratype MB.C.19027.3, at $12.0 \mathrm{~mm} \mathrm{dm}, 5.3 \mathrm{~mm}$ ww, $6.3 \mathrm{~mm}$ wh; $\times 6.0$. E. Suture line of paratype MB.C.19027.4, at $14.7 \mathrm{~mm} \mathrm{dm}, 5.8 \mathrm{~mm} w w, 15.2 \mathrm{~mm} w$; $\times$ 7.3. F. Suture line of holotype MB.C.19027.1, at $19.6 \mathrm{~mm} \mathrm{dm}, 7.4 \mathrm{~mm}$ ww, $9.5 \mathrm{~mm}$ wh; $\times 6.0$. G-I. Ontogenetic development of the conch width index (ww/dm), umbilical width index (uw/dm), whorl width index (ww/wh), and whorl expansion rate (WER) of all available specimens.

\section{Kusinia n. gen.}

Derivation of name. After the late Lidiya Kusina ( $†$ 2009), in honour of her contribution to the knowledge of the Tournaisian ammonoids.

Type species. Kusinia falcifera $\mathrm{n}$. sp.

Genus definition. Temertassetiidae with small conch, reaching approximately $35 \mathrm{~mm}$ diameter; conch ontogeny simple, juvenile stage thickly pachyconic and subinvolute, adult stage thinly discoidal and involute with narrowly rounded venter. Ornament with strongly biconvex riblets and intercalatory riblets; strong biconvex constrictions of the internal mould. Suture line with $\mathrm{V}$-shaped, narrow external lobe $(\mathrm{EL}$ w/d $\sim 0.60$; EL/AL $\sim 1.00$ in the adult stage) and very low median saddle (MS h $\sim 0.20$ ); ventrolateral saddle rounded; adventive lobe wide, V-shaped, asymmetric and acute.

Included species. falcifera: Kusinia falcifera n. sp.; Mouydir, Algeria.

Discussion. Kusinia has some superficial resemblance with Nigrocyclus Korn \& Feist, 2007 (type species: Pericyclus niger Delépine, 1935), but that genus possesses ribs with a more or less convex course and a very narrow external lobe with strongly diverging flanks. Kusinia is related to Jerania, but differs in the presence of sharp ribs.

\section{Kusinia falcifera n. sp.}

Figures 53, 54

Derivation of name. From Latin falcifera = sickle bearing, because of the ornament.

Holotype. Specimen MB.C.19046.1, illustrated in Figure 53A.

Type locality and horizon. Oued Temertasset, locality and sample MOU-Y (Mouydir, South Algeria); Helicocyclus-Ouaoufilalites Assemblage.

Material. 452 specimens, conch diameter up to $22 \mathrm{~mm}$.

Diagnosis. Kusinia with thickly pachyconic or globular conch in the early juvenile stage, becoming rapidly slender during ontogeny and being thinly discoidal at $20 \mathrm{~mm} \mathrm{dm}$; conch subinvolute in the early juvenile stage and involute above $2 \mathrm{~mm} \mathrm{dm}$; umbilical margin rounded; aperture low in juveniles and very high in the adult stage. Steinkern with strongly biconvex riblets and constrictions with shallow lateral sinus and a very deep and narrow ventral sinus; rib splitting and intercalated ribs common, adult stage without riblets. Suture line with narrow, V-shaped external lobe and very low median saddle in the adult stage; ventrolateral saddle asymmetric, broadly rounded; adventive lobe V-shaped, asymmetric with strongly curved ventral flank. 
Table 76. Conch ontogeny (Figs 54A-D, G-I) of Kusinia falcifera n. sp.

\begin{tabular}{|c|c|c|c|}
\hline$d m$ & conch shape & whorl cross section shape & aperture \\
\hline $2 \mathrm{~mm}$ & $\begin{array}{l}\text { thickly pachyconic; involute } \\
(\mathrm{ww} / \mathrm{dm}=0.75-0.80 ; \mathrm{uw} / \mathrm{dm}=0.12-0.15)\end{array}$ & $\begin{array}{l}\text { moderately depressed; very strongly embracing } \\
\text { (ww/wh }=1.50-1.60 ; \text { IZR }=0.50-0.58)\end{array}$ & $\begin{array}{l}\text { low } \\
(\text { WER }=1.60-1.70)\end{array}$ \\
\hline $8 \mathrm{~mm}$ & $\begin{array}{l}\text { thickly discoidal; involute } \\
(\mathrm{ww} / \mathrm{dm}=0.50-0.55 ; \mathrm{uw} / \mathrm{dm}=0.05-0.10)\end{array}$ & $\begin{array}{l}\text { weakly compressed; very strongly embracing } \\
\text { (ww/wh }=0.90-1.00 ; \mathrm{IZR} \sim 0.50 \text { ) }\end{array}$ & $\begin{array}{l}\text { moderate } \\
(\mathrm{WER}=1.80-2.00)\end{array}$ \\
\hline $20 \mathrm{~mm}$ & $\begin{array}{l}\text { thinly discoidal; involute } \\
\text { (ww/dm } \sim 0.36 ; \text { uw/dm } \sim 0.05 \text { ) }\end{array}$ & $\begin{array}{l}\text { weakly compressed; strongly embracing } \\
\text { (ww/wh } \sim 0.60 ; \text { IZR } \sim 0.40 \text { ) }\end{array}$ & $\begin{array}{l}\text { very high } \\
(\text { WER } \sim 2.40)\end{array}$ \\
\hline
\end{tabular}
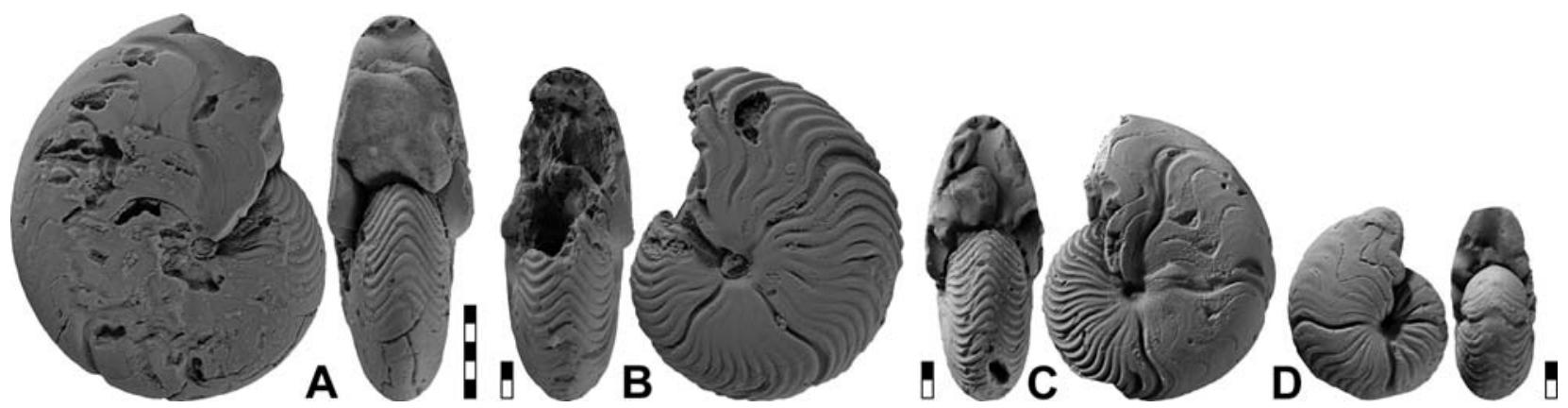

Figure 53. Kusinia falcifera n. sp.; all $\times 2$. A. Holotype MB.C.19046.1 from locality MOU-Y. B. Paratype MB.C.19046.2 from locality MOU-Y. C. Paratype MB.C.19038.1 from locality MOU-X. D. Paratype MB.C.19038.2 from locality MOU-X.
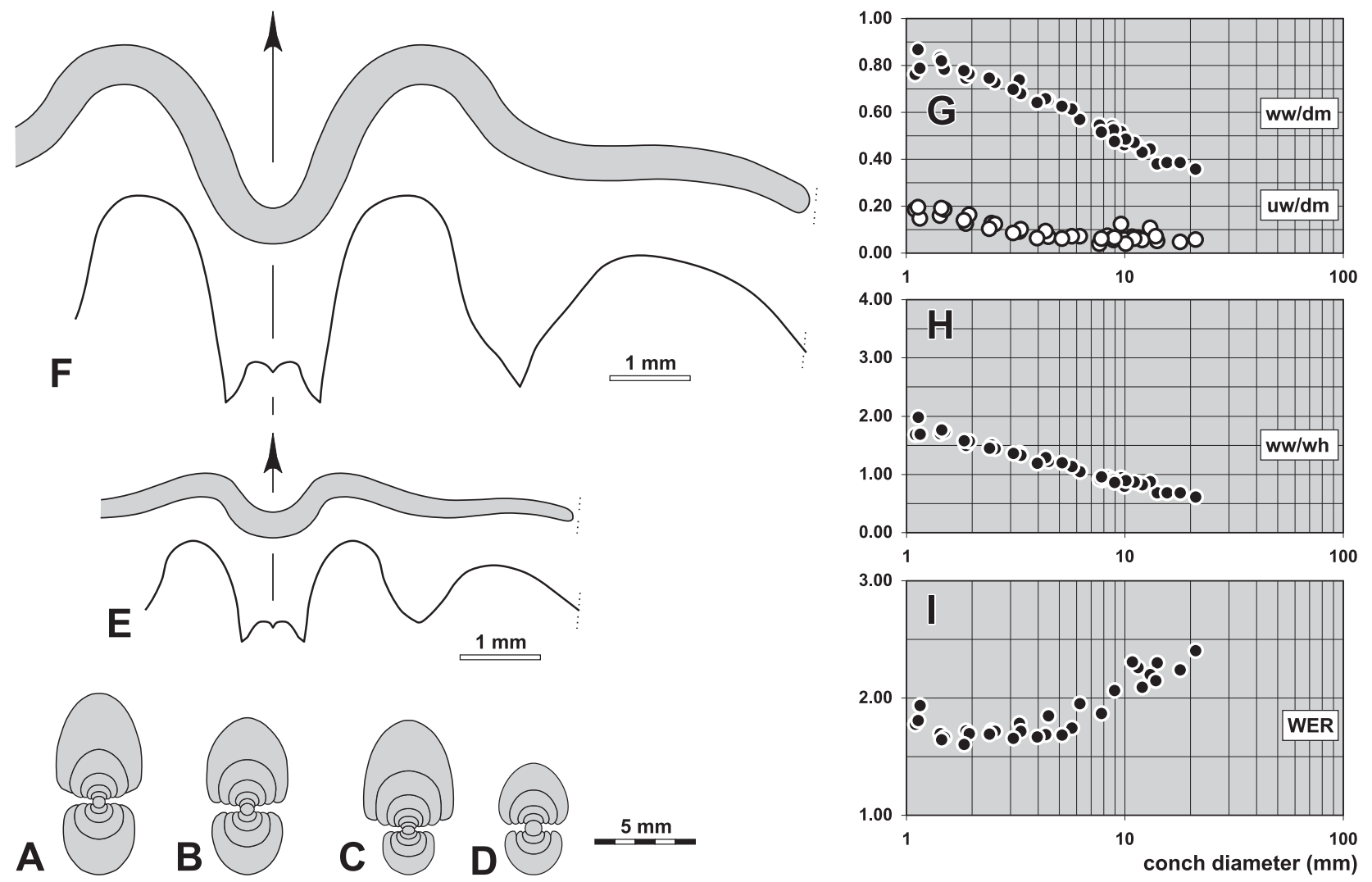

Figure 54. Kusinia falcifera n. sp. A. Cross section of paratype MB.C.19038.3 from locality MOU-X; $\times 2.5$. B. Cross section of paratype MB.C.19038.4 from locality MOU-X; $\times 2.5$. C. Cross section of paratype MB.C.19038.5 from locality MOU-X; $\times 2.5$. D. Cross section of paratype MB.C.18812.1 from locality MOU-C2; $\times 2.5$. E. Suture line and constriction of paratype MB.C.18984.1 from locality MOU-E11, at $10.3 \mathrm{~mm} \mathrm{dm}, 5.2 \mathrm{~mm} \mathrm{ww}, 6.0 \mathrm{~mm} \mathrm{wh} ; \times 10.0$. F. Suture line and constriction of holotype MB.C.19046.1 from locality MOU-Y, at $20.1 \mathrm{~mm} \mathrm{dm}, 7.9 \mathrm{~mm}$ ww, $12.9 \mathrm{~mm}$ wh; $\times 10.0$. G-I. Ontogenetic development of the conch width index $(w w / d m)$, umbilical width index (uw/dm), whorl width index (ww/wh), and whorl expansion rate (WER) of all available specimens. 
Table 77. Conch dimensions (in $\mathrm{mm}$ ) and proportions for reference specimens of Kusinia falcifera n. sp.

\begin{tabular}{|c|c|c|c|c|c|c|c|c|c|c|}
\hline & $\mathrm{dm}$ & ww & wh & uw & ah & $w w / d m$ & ww/wh & $\mathrm{uw} / \mathrm{dm}$ & WER & IZR \\
\hline holotype MB.C.19046.1 & 21.1 & 7.6 & 12.4 & 1.2 & 7.5 & 0.36 & 0.61 & 0.06 & 2.40 & 0.39 \\
\hline paratype MB.C.19046.2 & 17.9 & 6.9 & 10.2 & 0.9 & 5.9 & 0.39 & 0.68 & 0.05 & 2.24 & 0.41 \\
\hline paratype MB.C.18984.1 & 11.0 & 5.2 & 6.0 & 0.7 & 3.6 & 0.47 & 0.87 & 0.06 & 2.23 & 0.39 \\
\hline paratype MB.C.18984.2 & 10.8 & 4.5 & 5.9 & 0.8 & 3.7 & 0.42 & 0.77 & 0.07 & 2.31 & 0.37 \\
\hline
\end{tabular}

Table 78. Suture line proportions (Figs 54E, F) for Kusinia falcifera n. sp.

\begin{tabular}{llllllll}
\hline specimen & at dm & EL w/d & EL/VLS & EL/AL & MS h & VLS w/h & remarks \\
\hline holotype MB.C.19046.1 & $19.0 \mathrm{~mm}$ & 0.60 & 0.97 & 1.05 & 0.20 & 0.62 & A lobe strikingly asymmetric \\
paratype MB.C.18984.1 & $11.4 \mathrm{~mm}$ & 0.77 & 1.00 & 1.11 & 0.20 & 0.77 & E lobe comparatively wide \\
\hline
\end{tabular}

Discussion. Kusinia falcifera can easily be separated from any other species from Oued Temertasset by its combination of sickle-shaped ribs and biconvex constrictions on a discoidal conch. A similar conch, but not decorated with coarse ornamentation, can be seen in Jerania pusillens, which also possesses a similar suture line.

\section{Bouhamedites Korn, Bockwinkel, Ebbighausen \& Klug, 2003}

Type species. Bouhamedites enigmaticus Korn, Bockwinkel, Ebbighausen \& Klug, 2003

Genus definition. Temertassetiidae with small conch, reaching approximately $40 \mathrm{~mm}$ conch diameter; conch ontogeny simple, juvenile stage thickly pachyconic or globular and subinvolute, adult stage discoidal and involute with subacute venter. Ornament with biconvex riblets and intercalatory riblets. Suture line with V-shaped, narrow external lobe (EL w/d $\sim 0.60$; EL/AL $\sim 0.75$ ) and very low median saddle (MS h $<0.20$ ); ventrolateral saddle broadly rounded; adventive lobe wide, V-shaped.

Included species.

enigmaticus: Bouhamedites enigmaticus Korn, Bockwinkel, Ebbighausen \& Klug, 2003, p. 87; Anti-Atlas, Morocco.

insalahensis: Bouhamedites insalahensis n. sp.; Mouydir, Algeria.

ryckholti: Goniatites Ryckholti De Koninck, 1880, p. 100. Belgium.

Discussion. Bouhamedites can easily be separated from the other genera of the family by its subacute venter.

\section{Bouhamedites insalahensis $\mathbf{n} . \mathbf{s p}$.}

Figures 55, 56

Derivation of name. After the town In Salah north-west of the Mouydir.

Holotype. Specimen MB.C.18772, illustrated in Figure 55.

Type locality and horizon. Oued Temertasset, locality and sample MOU-D2 (Mouydir, South Algeria); upper Pericyclus-Progoniatites Assemblage.

Material. Two specimens, conch diameter 19 and $11 \mathrm{~mm}$.

Diagnosis. Bouhamedites with thinly globular conch up to $4 \mathrm{~mm} \mathrm{dm}$, thereafter rapidly becoming thickly discoidal at $20 \mathrm{~mm}$ dm; conch subinvolute in the early juvenile stage and involute in the adult stage; umbilical margin rounded, venter becoming oxyconic in the adult stage. Ornament with 50 weak, shallow ribs; rib course biconvex with very shallow lateral sinus and wide and deep ventral sinus; rib splitting on the inner flank. Steinkern without constrictions. Suture line with V-shaped, narrow external lobe with slowly diverging flanks; median saddle very low; ventrolateral saddle slightly asymmetric, broadly rounded; adventive lobe V-shaped, very wide.

Table 79. Conch ontogeny (Figs 56A, C-E) of Bouhamedites insalahensis n. sp.

\begin{tabular}{llll}
\hline $\mathrm{dm}$ & conch shape & whorl cross section shape & aperture \\
\hline $2 \mathrm{~mm}$ & thinly globular; subinvolute & moderately depressed; very strongly embracing & low \\
& $($ ww/dm $\sim 0.88 ;$ uw/dm $\sim 0.25)$ & $($ ww/wh $\sim 2.00 ;$ IZR $\sim 0.50)$ & mederate
\end{tabular}


Table 80. Conch dimensions (in $\mathrm{mm}$ ) and proportions for reference specimens of Bouhamedites insalahensis $\mathrm{n}$. $\mathrm{sp}$.

\begin{tabular}{lcccccccccc}
\hline & $\mathrm{dm}$ & ww & wh & uw & ah & ww/dm & ww/wh & uw/dm & WER & IZR \\
\hline holotype MB.C.18772 & 18.9 & 10.0 & 9.1 & 1.9 & 4.7 & 0.53 & 1.10 & 0.10 & 1.77 & 0.49 \\
paratype MB.C.18766 & 11.2 & 7.3 & 5.5 & 1.5 & 2.8 & 0.65 & 1.32 & 0.13 & 1.77 & 0.50 \\
\hline
\end{tabular}

Table 81. Suture line proportions (Fig. 56B) for Bouhamedites insalahensis n. sp.

\begin{tabular}{llllllll}
\hline specimen & at $\mathrm{dm}$ & EL w/d & EL/VLS & EL/AL & MS h & VLS w/h & remarks \\
\hline holotype MB.C.18772 & $17.1 \mathrm{~mm}$ & 0.60 & 0.67 & 0.74 & 0.16 & 0.89 & sutural elements rather low \\
\hline
\end{tabular}

Discussion. Bouhamedites insalahensis differs from the type species B. enigmaticus in its thicker conch and the coarser but shallower ribs. B. ryckholti is only poorly known and possesses a stouter conch and a narrowly rounded venter.
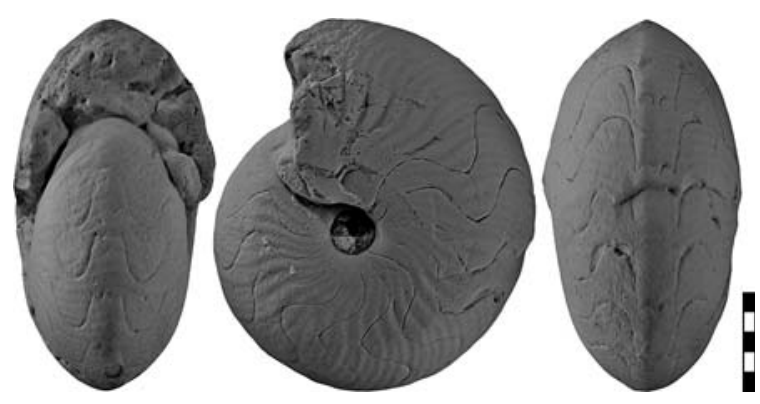

Figure 55. Bouhamedites insalahensis n. sp., holotype MB.C.18772 from locality MOU-D2; $\times 2.0$.

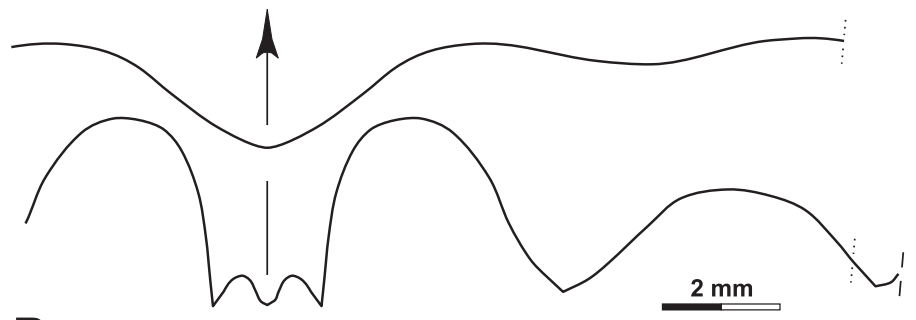

B
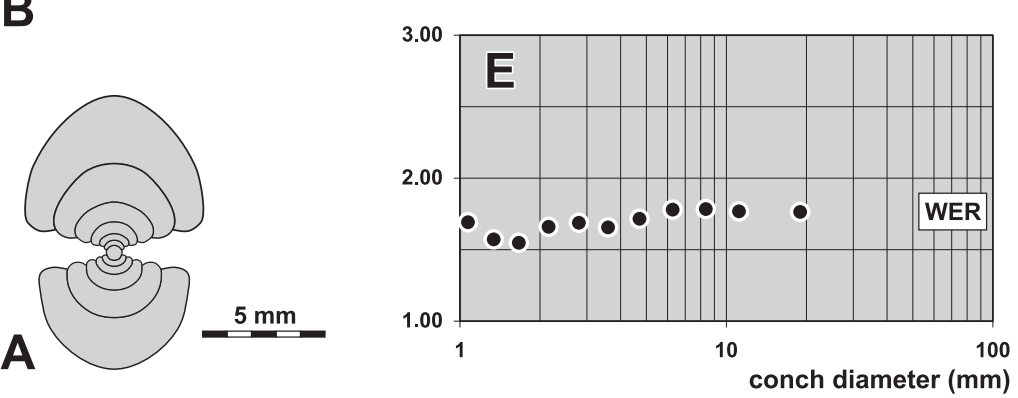
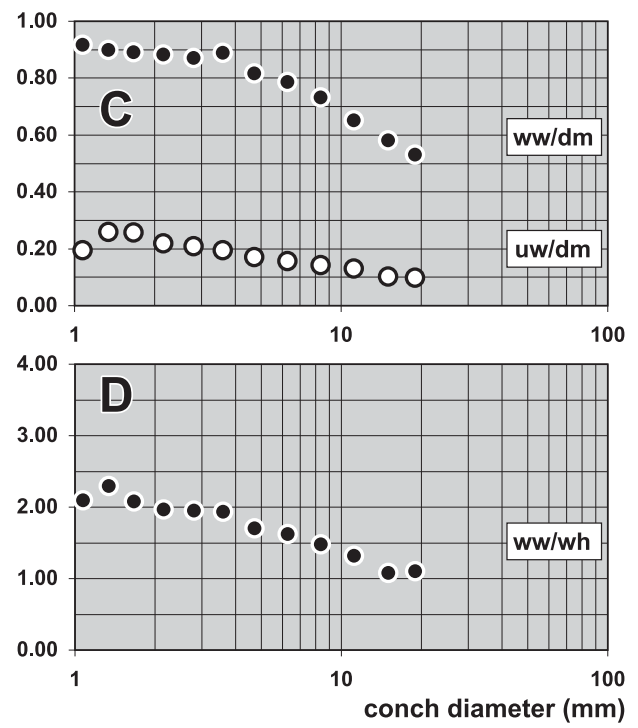

Figure 56. Bouhamedites insalahensis n. sp. A. Cross section of paratype MB.C.18766 from locality MOU-A; $\times 2.5$. B. Suture line and rib course of holotype MB.C.18772 from locality MOU-D2, at $17.1 \mathrm{~mm} \mathrm{dm}, 9.4 \mathrm{~mm} w w, 9.2 \mathrm{~mm}$ wh; $\times 6.0$. C-E. Ontogenetic development of the conch width index (ww/dm), umbilical width index (uw/dm), whorl width index (ww/wh), and whorl expansion rate (WER) of all available specimens.

Family Muensteroceratidae Librovitch, 1957

Family definition. Muensteroceratid ammonoids with usually discoidal and involute or subinvolute conch, rarely pachyconic or globular. Suture line with subparallel-sided or parallel-sided external lobe with straight flanks (external lobe V-shaped in ancestral forms); prongs of the external lobe lanceolate; median saddle very low to moderately low.

Included genera.

Muensteroceras Hyatt, 1884

Follotites n. gen.

Xinjiangites Ruan, 1995 
Akeshakeceras Liang \& Wang, 1991

Cluthoceras Currie, 1954

Eoglyphioceras Brüning, 1923

Itimaites Korn \& Ebbighausen, 2006

Terektytes Librovitch, 1957

Beyrichoceratoides Bisat, 1924

\section{Muensteroceras Hyatt, 1884}

Type species. Goniatites oweni var. parallela Hall, 1860 (OD).

Included species.

barroisi: Glyphioceras Barroisi Holzapfel, 1889, p. 30; Rhenish Mountains.

beniabbesense: Muensteroceras beniabbesense Korn, Ebbighausen \& Bockwinkel, 2010; Saoura Valley, Algeria.

collinsoni: Muensteroceras collinsoni Gordon, 1965, p. 178; Arkansas.

compressum: Muensteroceras kazakhstanicum var. compressa Librovitch, 1940, p. 106; Karaganda.

cordatum: Glyphioceras cordatum Crick, 1899, p. 445; Ireland.

esbaughi: Muensteroceras esbaughi Miller, Downs \& Youngquist, 1949, p. 604; Missouri.

fabrei: Muensteroceras fabrei Ebbighausen, Korn \& Bockwinkel, 2010; Gourara, Algeria.

frequens: Muensteroceras frequens Kusina, 1973, p. 18; North Urals.

inconstans: Goniatites inconstans de Koninck, 1880, p. 120; Belgium. [homonym of Goniatites inconstans Phillips, 1841; synonym of M. koninckianum]

jenkinsi: Muensteroceras jenkinsi Campbell, Brown \& Coleman, 1983, p. 86; New South Wales.

kazakhstanicum: Muensteroceras kazakhstanicum Librovitch, 1940, p. 99; Karaganda.

koninckianum: Münsteroceras koninckianum Schindewolf, 1951, p. 64; Belgium.

kozhimense: Muensteroceras kozhimense Kusina, 1980, p. 45; North Urals.

malladae: Goniatites Malladae Barrois, 1882, p. 293; Cantabrian Mountains.

medium: Munsteroceras medium Miller \& Collinson, 1951, p. 472; Missouri.

merlewoodense: Muensteroceras merlewoodense Campbell, Brown \& Coleman, 1983, p. 88; New South Wales.

multiseptatum: Muensteroceras kazakhstanicum var. multiseptata Librovitch, 1940, p. 108; Karaganda.

multitudum: Muensteroceras multitudum n. sp.; Mouydir, Algeria.

nandanense: Muensteroceras nandanense Chao \& Liang, 1964, p. 87; Guangxi.

occidentale: Glyphioceras (Beyrichoceras) occidentale Foord, 1903, p. 170; Ireland.

oweni: Goniatites oweni Hall, 1860, p. 100; Indiana.

pachydiscus: Muensteroceras pachydiscus Kusina, 1980, p. 43; North Urals.

parallelum: Goniatites oweni var. parallela Hall, 1860, p. 100; Indiana.

parvulum: Muensteroceras parvulum Kusina, 1983, p. 92; North Urals.

pergibbosum: Münsteroceras pergibbosum Miller \& Garner, 1955, p. 140; Michigan.

pfefferae: Imitoceras pfefferae Miller \& Werner, 1942, p. 480; Illinois.

quadriconstrictum: Muensteroceras quadriconstrictum Korn, Bockwinkel, Ebbighausen \& Klug, 2003, p. 80; Anti-Atlas.

recticonstrictum: Muensteroceras recticonstrictum Kusina, 1973, p. 17; North Urals.

roemeri: Glyphioceras Roemeri Holzapfel, 1889, p. 27; Rhenish Mountains.

rowleyi: Muensteroceras rowleyi Miller \& Furnish, 1958, p. 272; Missouri.

stoliczkai: Karakoramoceras stoliczkai Miller, 1931, p. 423; Kashmir.

subparallelum: Muensteroceras subparallelum n. sp.; Mouydir, Algeria

? holmesii: Goniatites Holmesii Swallow, 1860, p. 659; Missouri.

? mitchelli: Münsteroceras mitchelli Miller, 1935, p. 435; Missouri.

? morganense: Goniatites Morganensis Swallow, 1860, p. 659; Missouri.

? pygmaeum: Münsteroceras pygmaeus Winchell, 1862, p. 366; Michigan.

Separation of the new species. The two species of Muensteroceras from Oued Temertasset can be separated by means of conch morphology and the steinkern constrictions:

- M. subparallelum - conch at $8 \mathrm{~mm} \mathrm{dm}$ thickly discoidal; involute (ww/dm $=0.55-0.60$; uw/dm $0.10-0.15$ ); at 20 mm dm thinly discoidal; involute $(\mathrm{ww} / \mathrm{dm}=0.45-0.50 ; \mathrm{uw} / \mathrm{dm}=0.10-0.15)$; constrictions rectiradiate, usually convex.

- M. multitudum - conch at $8 \mathrm{~mm} \mathrm{dm}$ thinly pachyconic; involute or subinvolute $(\mathrm{ww} / \mathrm{dm}=0.60-0.75 ; \mathrm{uw} / \mathrm{dm}=0.10-0.25)$; at $18 \mathrm{~mm} \mathrm{dm}$ thickly discoidal; involute $(\mathrm{ww} / \mathrm{dm}=0.50-0.58 ; \mathrm{uw} / \mathrm{dm}=0.12-0.15)$; constrictions prorsiradiate, concavo-convex.

Discussion. Many of the species attributed to the genus Muensteroceras are insufficiently described and require revision. Characters of the inner whorls, for instance, are poorly known for many of them, casting doubts on their correct assignment. Particularly the stratigraphically younger species with rather stout conches have to be investigated in greater detail, because some of them might belong to the new genera proposed here.

\section{Muensteroceras subparallelum n. sp.}

Figures 57, 58

Derivation of name. From Latin parallelus, because of the not perfectly parallel flanks of the external lobe.

Holotype. Specimen MB.C.19058.1, illustrated in Figure 57A. 
Type locality and horizon. Oued Temertasset, locality and sample MOU-F (Mouydir, South Algeria); upper Pericyclus-Progoniatites Assemblage.

Material. 267 specimens, conch diameter up to $41 \mathrm{~mm}$.

Diagnosis. Muensteroceras with thickly pachyconic conch in early juveniles, thereafter continuous transformation into a thinly discoidal conch at $20 \mathrm{~mm} \mathrm{dm}$; conch subinvolute in the early juvenile stage and involute in stages above $8 \mathrm{~mm} \mathrm{dm}$; umbilicus funnel-shaped, umbilical margin subangular, umbilical wall flattened and oblique; aperture low in juveniles and moderately high above $6 \mathrm{~mm} \mathrm{dm}$. Steinkern with sharp rectiradiate constrictions, course convex or slightly biconvex with extremely shallow lateral sinus and deep ventral sinus; weak riblets occur occasionally between the constrictions. Suture line with very narrow, parallel-sided external lobe and very low median saddle (external lobe with slightly diverging flanks rare in adults and more common in juveniles); ventrolateral saddle broadly rounded and asymmetric; adventive lobe V-shaped, almost symmetric with slightly curved flanks.

Table 82. Conch ontogeny (Figs 58A-F, I-K) of Muensteroceras subparallelum $\mathrm{n}$. sp.

\begin{tabular}{llll}
\hline $\mathrm{dm}$ & conch shape & whorl cross section shape & aperture \\
\hline $2 \mathrm{~mm}$ & thickly pachyconic; subinvolute & moderately depressed; very strongly embracing & low to moderate \\
& $($ ww/dm $=0.70-0.85 ;$ uw $/ \mathrm{dm}=0.22-0.30)$ & $($ ww/wh $=1.55-1.75 ;$ IZR $=0.45-0.50)$ & (WER $=1.65-1.85)$ \\
$8 \mathrm{~mm}$ & thickly discoidal; involute & weakly depressed; very strongly embracing & moderate \\
& $($ ww/dm $=0.55-0.60 ;$ uw $/ \mathrm{dm}=0.10-0.15)$ & $($ ww/wh $=1.10-1.25 ;$ IZR $=0.45-0.50)$ & $($ WER $=1.80-2.00)$ \\
$20 \mathrm{~mm}$ & thinly discoidal; involute & weakly compressed; very strongly embracing & moderate \\
& $($ ww/dm $=0.45-0.50 ;$ uw $/ \mathrm{dm}=0.10-0.15)$ & $($ ww/wh $=0.85-1.00 ;$ IZR $=0.45-0.50)$ & $($ WER $=1.75-1.95)$ \\
$30 \mathrm{~mm}$ & thinly discoidal; involute & weakly compressed; very strongly embracing & moderate \\
& $($ ww/dm $=0.42-0.48 ;$ uw/dm $=0.12-0.15)$ & $($ ww/wh $=0.85-1.00 ;$ IZR $=0.45-0.50)$ & $($ WER $\sim 1.80)$ \\
\hline
\end{tabular}

Table 83. Conch dimensions (in $\mathrm{mm}$ ) and proportions for reference specimens of Muensteroceras subparallelum $\mathrm{n}$. $\mathrm{sp}$.

\begin{tabular}{lccccccccccc}
\hline & $\mathrm{dm}$ & ww & wh & uw & ah & ww/dm & ww/wh & uw/dm & WER & IZR \\
\hline paratype 1798 & 40.4 & 18.3 & 19.0 & 6.6 & 10.6 & 0.45 & 0.96 & 0.16 & 1.84 & 0.44 \\
holotype MB.C.19058.1 & 25.8 & 11.3 & 12.3 & 4.1 & - & 0.44 & 0.92 & 0.16 & - & - \\
paratype MB.C.18874.1 & 22.6 & 10.7 & 11.0 & 3.2 & 5.7 & 0.47 & 0.97 & 0.14 & 1.79 & 0.48 \\
paratype MB.C.19058.2 & 17.1 & 9.2 & 8.0 & 2.4 & 4.4 & 0.54 & 1.16 & 0.14 & 1.83 & 0.44 \\
paratype MB.C.18874.2 & 13.3 & 8.1 & 5.8 & 2.5 & 3.2 & 0.61 & 1.39 & 0.19 & 1.74 & 0.45 \\
\hline
\end{tabular}
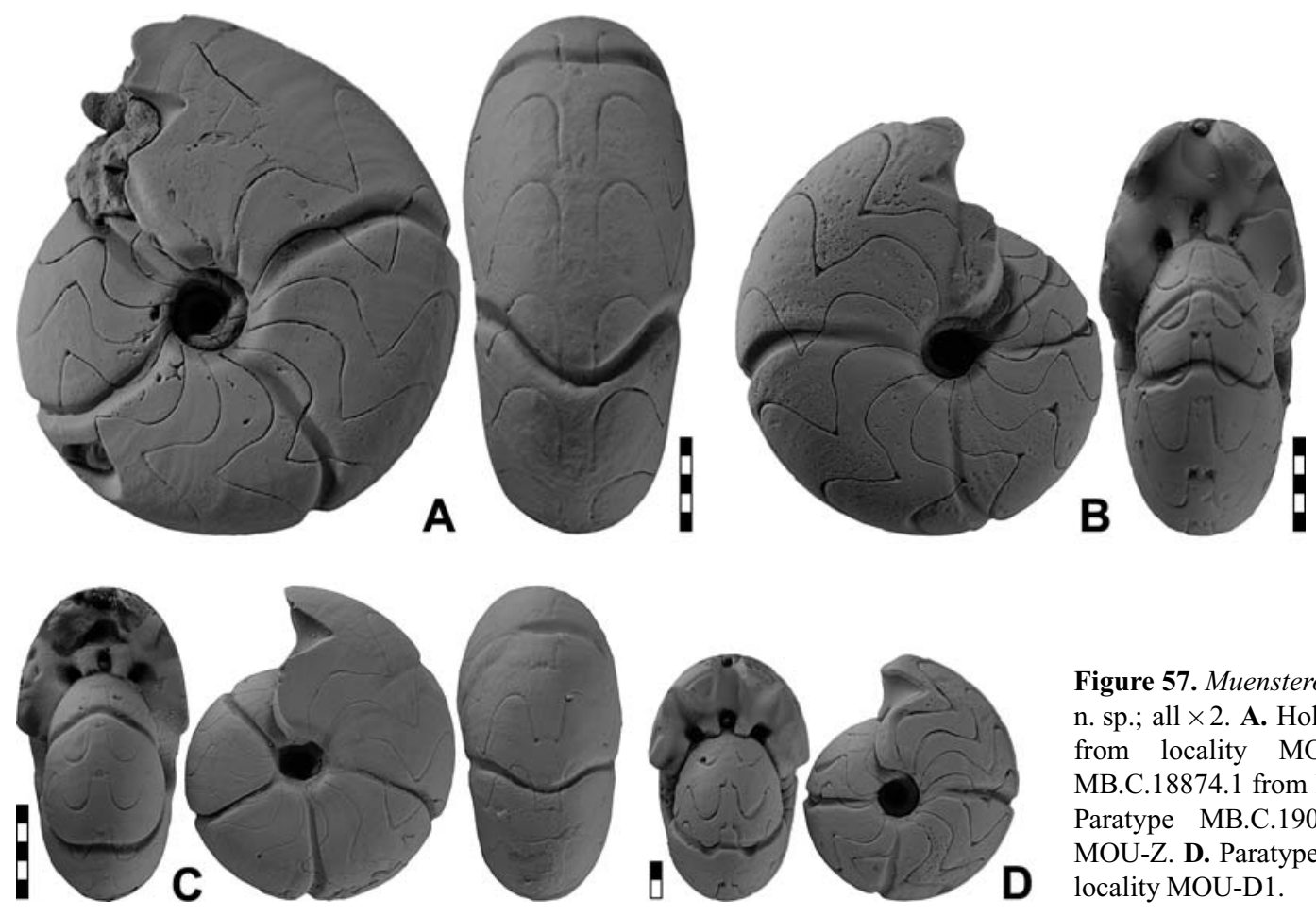

Figure 57. Muensteroceras subparallelum n. sp.; all $\times 2$. A. Holotype MB.C. 19058.1 from locality MOU-F. B. Paratype MB.C.18874.1 from locality MOU-D1. C. Paratype MB.C.19058.2 from locality MOU-Z. D. Paratype MB.C.18874.2 from locality MOU-D1. 
Table 84. Suture line proportions (Figs 58G, H) for Muensteroceras subparallelum n. sp.

\begin{tabular}{llllllll}
\hline specimen & at dm & EL w/d & EL/VLS & EL/AL & MS h & VLS w/h & remarks \\
\hline holotype MB.C.19058.1 & $23.7 \mathrm{~mm}$ & 0.38 & 0.47 & 0.61 & 0.17 & 0.80 & A lobe with almost straight flanks \\
paratype MB.C.18874.1 & $19.1 \mathrm{~mm}$ & 0.34 & 0.44 & 0.72 & 0.19 & 0.78 & A lobe with curved flanks \\
\hline
\end{tabular}
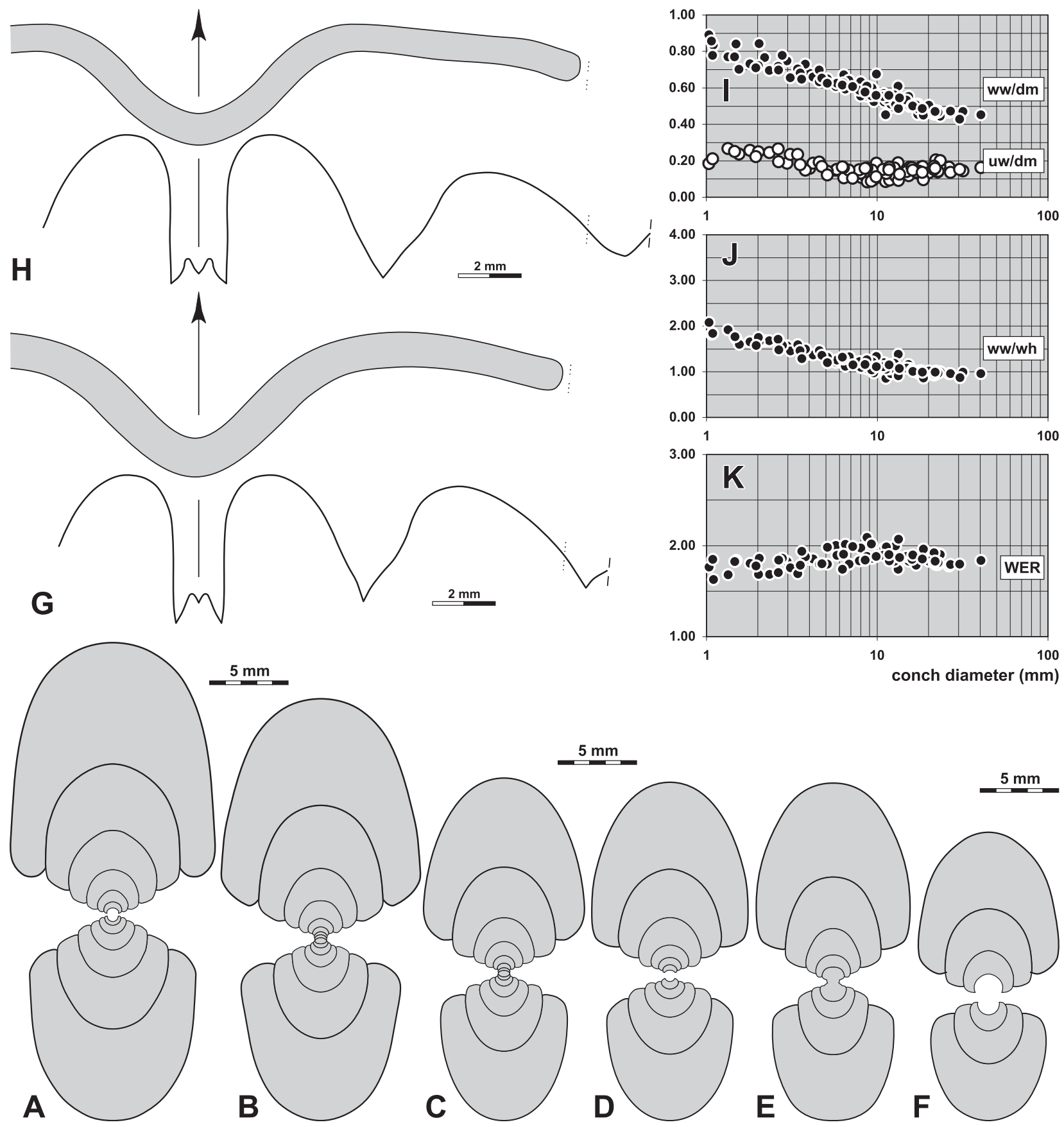

Figure 58. Muensteroceras subparallelum n. sp. A. Cross section of paratype MB.C.18874.3 from locality MOU-D1; $\times 2.5$. B. Cross section of paratype MB.C.18874.4 from locality MOU-D1; $\times 2.5$. C. Cross section of paratype MB.C.19058.3 from locality MOU-Z; $\times 2.5$. D. Cross section of paratype MB.C.19058.4 from locality MOU-Z; $\times 2.5$. E. Cross section of paratype MB.C.19012.1 from locality MOU-F; $\times 2.5$. F. Cross section of paratype MB.C.18874.5 from locality MOU-D1; $\times 2.5$. G. Suture line and constriction of paratype MB.C.18874.1 from locality MOU-D1, at $19.1 \mathrm{~mm} \mathrm{dm}, 10.5 \mathrm{~mm} \mathrm{ww}, 10.7 \mathrm{~mm}$ wh; $\times 5.0$. H. Suture line and constriction of holotype MB.C.19058.1 from locality MOU-Z, at $23.7 \mathrm{~mm} \mathrm{dm}, 11.1 \mathrm{~mm} \mathrm{ww}, 11.8 \mathrm{~mm} \mathrm{wh} ; \times 5.0$. IK. Ontogenetic development of the conch width index (ww/dm), umbilical width index (uw/dm), whorl width index (ww/wh), and whorl expansion rate (WER) of all available specimens. 
Discussion. Muensteroceras subparallelum belongs to the narrowly umbilicate species of the genus and is thus separated from most of the other species (see Korn et al. 2003 for a discussion of M. quadriconstrictum). M. quadriconstrictum from the Anti-Atlas is similar but has a much narrower umbilicus (at $20 \mathrm{~mm} \mathrm{dm}$ : uw/dm usually less than 0.10 in M. quadriconstrictum but around 0.15 in M. subparallelum).

M. subparallelum resembles the type species of the genus in the ornament and suture line, but has a more slender juvenile conch (at $10 \mathrm{~mm} \mathrm{dm}$ : ww/dm $=0.50-0.55$ in M. subparallelum but 0.65-0.70 in M. parallelum).

\section{Muensteroceras multitudum n. sp.}

Figures 59, 60

Derivation of name. From Latin multitudum = large number, because of the frequency of the species.

Holotype. Specimen MB.C.18848.1, illustrated in Figure 59D.

Type locality and horizon. Oued Temertasset, locality and sample MOU-C (Mouydir, South Algeria); Helicocyclus-Ouaoufilalites Assemblage.

Material. 1,170 specimens, conch diameter up to $28 \mathrm{~mm}$.

Diagnosis. Muensteroceras with thickly pachyconic conch in the early juvenile stage, almost continuously becoming more slender and being thickly discoidal at $18 \mathrm{~mm} \mathrm{dm}$; conch subinvolute in the juvenile stage and later becoming involute; umbilical margin and umbilical wall rounded; aperture low to moderate in juveniles and becoming high during ontogeny. Steinkern with prorsiradiate constrictions, course slightly biconvex with shallow lateral sinus, moderately high ventrolateral projection, and deep ventral sinus. Suture line with very narrow, parallel-sided external lobe and very low median saddle; ventrolateral saddle almost symmetric, broadly rounded; adventive lobe V-shaped, acute.

Table 85. Conch ontogeny (Figs $60 \mathrm{~A}-\mathrm{H}, \mathrm{L}-\mathrm{N}$ ) of Muensteroceras multitudum $\mathrm{n}$. sp.

\begin{tabular}{|c|c|c|c|}
\hline$d m$ & conch shape & whorl cross section shape & aperture \\
\hline $2 \mathrm{~mm}$ & $\begin{array}{l}\text { thickly pachyconic; subinvolute } \\
(\mathrm{ww} / \mathrm{dm}=0.75-0.85 ; \mathrm{uw} / \mathrm{dm}=0.15-0.25)\end{array}$ & $\begin{array}{l}\text { moderately depressed; strongly or very strongly } \\
\text { embracing ( } w w / w h=1.50-1.90 ; \mathrm{IZR}=0.40-0.50 \text { ) }\end{array}$ & $\begin{array}{l}\text { low to moderate } \\
(\mathrm{WER}=1.65-1.80)\end{array}$ \\
\hline $8 \mathrm{~mm}$ & $\begin{array}{l}\text { thinly to thickly pachyconic; involute or subinvolute } \\
\text { (ww/dm }=0.60-0.75 ; \mathrm{ww} / \mathrm{dm}=0.10-0.25 \text { ) }\end{array}$ & $\begin{array}{l}\text { weakly or moderately depressed; strongly } \\
\text { embracing ( } w w / w h=1.15-1.65 ; \mathrm{IZR}=0.30-0.45 \text { ) }\end{array}$ & $\begin{array}{l}\text { moderate to high } \\
(\mathrm{WER}=1.85-2.10)\end{array}$ \\
\hline $20 \mathrm{~mm}$ & $\begin{array}{l}\text { thickly discoidal; involute } \\
(\mathrm{ww} / \mathrm{dm}=0.50-0.58 ; \mathrm{uw} / \mathrm{dm}=0.12-0.15)\end{array}$ & $\begin{array}{l}\text { weakly compressed or weakly depressed; } \\
\text { strongly embracing } \\
(\text { ww/wh }=0.90-1.10 ; \text { IZR }=0.30-0.40)\end{array}$ & $\begin{array}{l}\text { high } \\
(\text { WER }=2.00-2.15)\end{array}$ \\
\hline
\end{tabular}
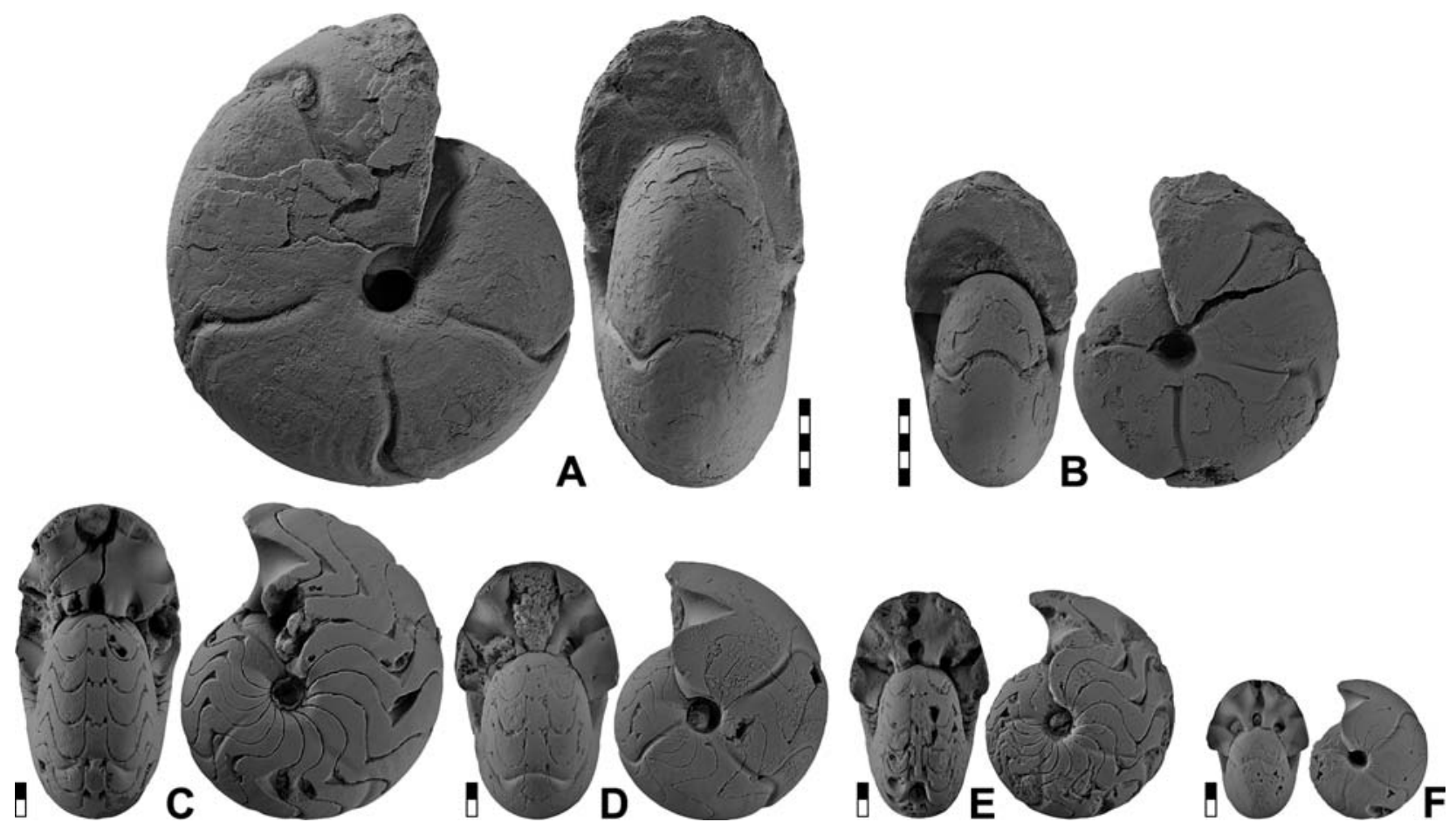

Figure 59. Muensteroceras multitudum n. sp.; all $\times 2$. A. Paratype MB.C.18818.1 from locality MOU-C3. B. Paratype MB.C.18818.2 from locality MOU-C3. C. Paratype MB.C.18992.1 from locality MOU-E12. D. Holotype MB.C.18848.1 from locality MOU-C. E. Paratype MB.C.18848.2 from locality MOU-C. F. Paratype MB.C.18848.3 from locality MOU-C. 


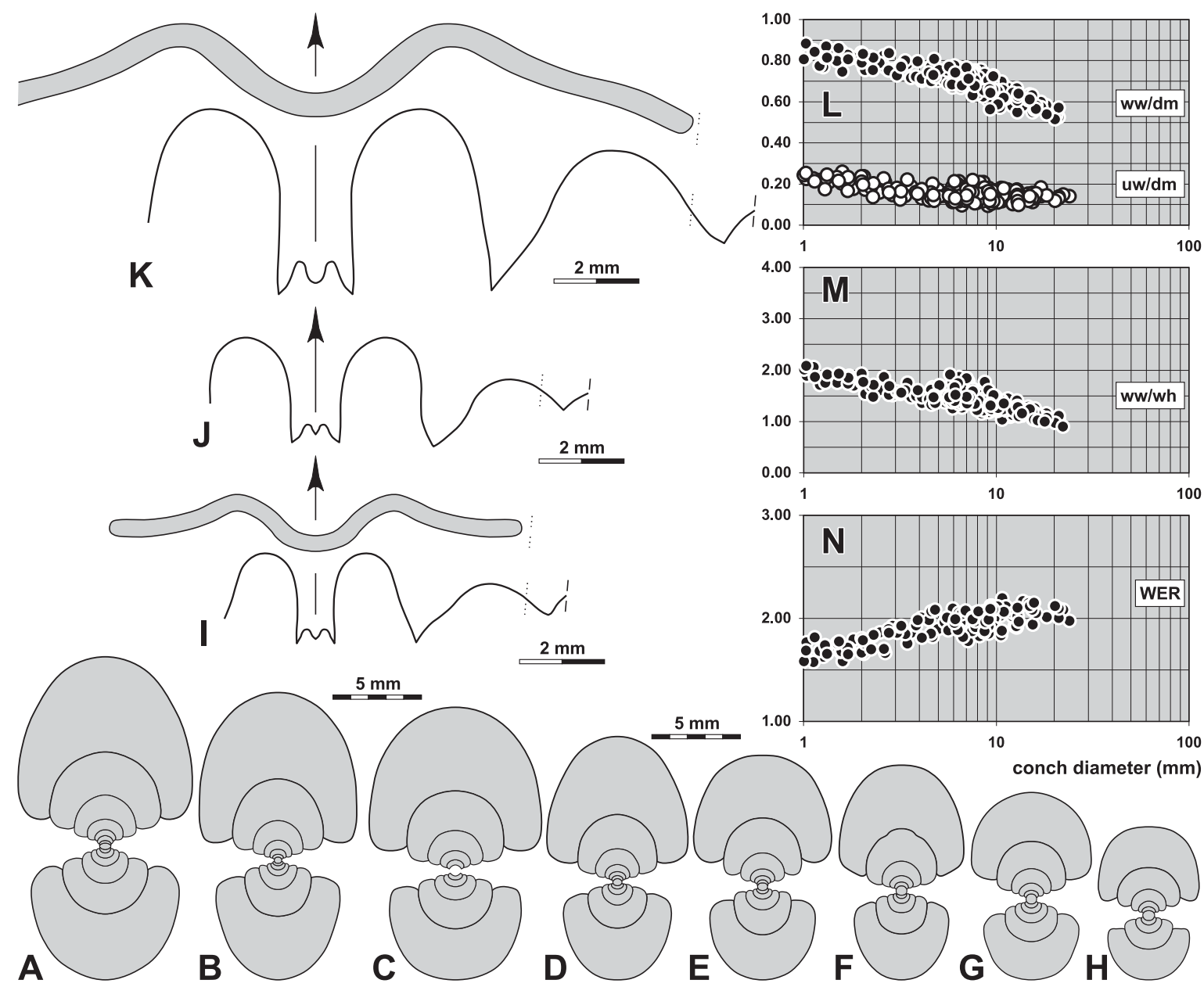

Figure 60. Muensteroceras multitudum n. sp. A. Cross section of paratype MB.C.19039.1 from locality MOU-X; $\times 2.5$. B. Cross section of paratype MB.C.19039.2 from locality MOU-X; $\times 2.5$. C. Cross section of paratype MB.C.19039.3 from locality MOU-X; $\times 2.5$. D. Cross section of paratype MB.C.19039.4 from locality MOU-X; $\times 2.5$. E. Cross section of paratype MB.C.19039.5 from locality MOUX; $\times 2.5$. F. Cross section of paratype MB.C.19039.6 from locality MOU-X; $\times 2.5$. G. Cross section of paratype MB.C.19039.7 from locality MOU-X; $\times 2.5$. H. Cross section of paratype MB.C.19039.8 from locality MOU-X; $\times 2.5$. I. Suture line and constriction of paratype MB.C.18848.3 from locality MOU-C4 + 5, at $7.9 \mathrm{~mm} \mathrm{dm}, 5.6 \mathrm{~mm}$ ww, $4.1 \mathrm{~mm}$ wh; $\times 6.0$. J. Suture line of holotype MB.C.18848.1 from locality MOU-C4 +5 , at $5.9 \mathrm{~mm}$ ww, $4.2 \mathrm{~mm}$ wh; $\times 6.0$. K. Suture line and constriction of holotype MB.C.18848.1 from locality MOU-C4 + 5, at $13.3 \mathrm{~mm} \mathrm{dm}, 8.6 \mathrm{~mm}$ ww, $7.5 \mathrm{~mm}$ wh; $\times 6.0$. L-N. Ontogenetic development of the conch width index (ww/dm), umbilical width index (uw/dm), whorl width index (ww/wh), and whorl expansion rate (WER) of all available specimens.

Table 86. Conch dimensions (in $\mathrm{mm}$ ) and proportions for reference specimens of Muensteroceras multitudum $\mathrm{n}$. $\mathrm{sp}$.

\begin{tabular}{lrrrrrrrrrr}
\hline & dm & ww & wh & uw & ah & ww/dm & ww/wh & uw/dm & WER & IZR \\
\hline paratype MB.C.18818.1 & 27.5 & 13.3 & 13.8 & 3.7 & 7.8 & 0.48 & 0.96 & 0.14 & 1.95 & 0.43 \\
paratype MB.C.18818.2 & 18.2 & 9.8 & 8.9 & 1.9 & 5.9 & 0.54 & 1.10 & 0.10 & 2.18 & 0.34 \\
paratype MB.C.18992.1 & 17.1 & 9.0 & 8.4 & 2.0 & 5.5 & 0.53 & 1.08 & 0.12 & 2.16 & 0.35 \\
holotype MB.C.18848.1 & 15.0 & 9.1 & 7.4 & 2.1 & 4.7 & 0.61 & 1.24 & 0.14 & 2.12 & 0.36 \\
paratype MB.C.18848.2 & 12.9 & 7.8 & 6.0 & 1.8 & 3.8 & 0.61 & 1.30 & 0.14 & 2.02 & 0.36 \\
paratype MB.C.18848.3 & 8.1 & 5.6 & 4.0 & 1.0 & 2.5 & 0.70 & 1.40 & 0.12 & 2.07 & 0.39 \\
\hline
\end{tabular}

Table 87. Suture line proportions (Figs 60I-K) for Muensteroceras multitudum n. sp.

\begin{tabular}{llllllll}
\hline specimen & at dm & EL w/d & EL/VLS & EL/AL & MS h & VLS w/h & remarks \\
\hline holotype MB.C.18848.1 & $14.9 \mathrm{~mm}$ & 0.38 & 0.55 & 0.98 & 0.17 & 0.69 & A lobe asymmetric \\
dto. & c. $8.0 \mathrm{~mm}$ & 0.50 & 0.66 & 0.95 & 0.17 & 0.76 & A lobe lanceolate \\
paratype MB.C.18848.3 & $7.7 \mathrm{~mm}$ & 0.41 & 0.56 & 0.65 & 0.16 & 0.73 & A lobe V-shaped, wide \\
\hline
\end{tabular}


Discussion. Muensteroceras multitudum has a marginal position within the genus because of its prorsiradiate steinkern constrictions, which separates the new species from all other species that possess, if at all, rectiradiate constrictions.

\section{Follotites n. gen.}

Derivation of name. After Jacques Follot, in honour to his discovery of the Tournaisian ammonoid occurrence at Oued Temertasset.

Type species. Follotites folloti n. sp.

Genus definition. Muensteroceratidae with rather small conch, reaching $50 \mathrm{~mm}$ conch diameter. Conch pachyconic, subinvolute or involute with moderate ontogenetic changes. Steinkern without or with weak convex or concavo-convex constrictions. Suture line with parallel-sided, very narrow external lobe $(E L \mathrm{w} / \mathrm{d}=0.35-0.45 ; \mathrm{EL} / \mathrm{AL}=0.60-0.90)$ and very low median saddle $(\mathrm{MS} \mathrm{h}=0.15-0.20)$; ventrolateral saddle broadly rounded, slightly asymmetric; adventive lobe V-shaped, slightly asymmetric.

Included species.

flexus: Follotites flexus n. sp.; Mouydir, Algeria.

folloti: Follotites folloti n. sp.; Mouydir, Algeria.

stelus: Follotites stelus n. sp.; Mouydir, Algeria.

Separation of the new species. The three species of Follotites from Oued Temertasset can be separated by means of conch morphology and the suture line. In the conch ontogeny, they can be distinguished as follows:

- F. folloti - the uw/dm ratio remains, between 1 and $8 \mathrm{~mm} \mathrm{dm}$, stable at $0.14-0.20$, followed by a slight decrease to $0.07-0.11$ in larger stages; the ww/dm ratio is rather stable up to $13 \mathrm{~mm} \mathrm{dm}(0.83-0.88)$ with a subsequent decrease to $0.70-0.75$ at $20-30 \mathrm{~mm}$ dm; the aperture height is not constant during ontogeny with a value between 1.80 and 2.00 above $10 \mathrm{~mm} \mathrm{dm}$.

- F. stelus - the uw/dm ratio amounts, between 1 and $8 \mathrm{~mm} \mathrm{dm}$, to approximately 0.14 , followed by a slight increase to $0.17-0.24$ in larger stages; the ww/dm ratio is rather stable up to $16 \mathrm{~mm} \mathrm{dm}(0.83-0.86)$ with a subsequent decrease to $0.64-0.68$ at $20-30 \mathrm{~mm}$ dm; the aperture height is not constant during ontogeny and the whorl expansion rate ranges between 1.60 and 1.80 above $10 \mathrm{~mm} \mathrm{dm}$.

- F. flexus - the uw/dm ratio ranges, throughout ontogeny, between 0.10 and 0.15 , with the exception of a growth interval between 5 and $20 \mathrm{~mm}$ dm in which the umbilicus is opened wider (uw/dm up to 0.26 ); the ww/dm ratio is unstable up to $13 \mathrm{~mm} \mathrm{dm}(0.83-0.98)$ with a subsequent reduction to 0.65 at $20-30 \mathrm{~mm} \mathrm{dm}$; the aperture height is rather constant during ontogeny with a slight increase to 1.80 and 2.00 above $20 \mathrm{~mm}$ dm.

The steinkern surface displays more differences:

- F. folloti and F. stelus - constrictions are, if present at all, very weak; they are convex with a wide and low projection on the flank and a wide and shallow ventral sinus.

- F. flexus - constrictions are strong; they form a weak lateral sinus, a low ventrolateral projection, and a wide and shallow ventral sinus.

Discussion. Follotites differs from Muensteroceras in the much stouter conch and the different ontogeny of the umbilicus; in Muensteroceras the umbilicus is normally slightly opened in the adult stage, whereas it is being closed in Follotites. Species of Eurites possess also a stout conch, but in these species, the umbilicus is almost constantly opened during ontogeny with a temporary acceleration in the intermediate growth stage. Trimorphoceras Ebbighausen et al., 2010 shows an adult closure of the umbilicus, but differs from Follotites in the much more conspicuous ontogenetic changes.

\section{Follotites folloti n. sp.}

Figures 61, 62

Derivation of name. After Jaques Follot.

Holotype. Specimen MB.C.18734.1, illustrated in Figure 61A.

Type locality and horizon. Oued Temertasset, locality and sample A320-5 (Mouydir, South Algeria); Helicocyclus-Ouaoufilalites Assemblage.

Material. 13 specimens, conch diameter up to $35 \mathrm{~mm}$.

Diagnosis. Follotites with thickly pachyconic or globular and subinvolute conch up to $8 \mathrm{~mm}$ dm, thereafter transformation into a thinly pachyconic and involute adult conch; umbilical margin rounded, umbilical wall convex; aperture low in juveniles and moderate in the adult stage. Steinkern without or with very weak convex constrictions with moderately deep and wide ventral sinus. Suture line with very narrow, subparallel-sided or parallel-sided external lobe and very low median saddle; ventrolateral saddle broadly rounded and slightly asymmetric; adventive lobe V-shaped, almost symmetric.

Table 88. Conch ontogeny (Figs 62A, E-G) of Follotites folloti n. sp.

\begin{tabular}{|c|c|c|c|}
\hline $\mathrm{dm}$ & conch shape & whorl cross section shape & aperture \\
\hline $2 \mathrm{~mm}$ & $\begin{array}{l}\text { thinly globular; subinvolute } \\
\text { (ww/dm } \sim 0.85 ; \text { uw/dm } \sim 0.18 \text { ) }\end{array}$ & $\begin{array}{l}\text { moderately depressed; very strongly embracing } \\
\text { (ww/wh } \sim 1.80 ; \text { IZR } \sim 0.50 \text { ) }\end{array}$ & $\begin{array}{l}\text { low } \\
(\text { WER } \sim 1.70)\end{array}$ \\
\hline $8 \mathrm{~mm}$ & $\begin{array}{l}\text { thinly globular; subinvolute } \\
\text { (ww/dm } \sim 0.90 ; \text { uw/dm } \sim 0.15 \text { ) }\end{array}$ & $\begin{array}{l}\text { moderately depressed; very strongly embracing } \\
\text { (ww/wh } \sim 1.80 ; \mathrm{IZR} \sim 0.50 \text { ) }\end{array}$ & $\begin{array}{l}\text { low } \\
(\text { WER } \sim 1.75)\end{array}$ \\
\hline $20 \mathrm{~mm}$ & $\begin{array}{l}\text { thickly pachyconic; involute } \\
(\mathrm{ww} / \mathrm{dm}=0.70-0.80 ; \mathrm{uw} / \mathrm{dm}=0.05-0.10)\end{array}$ & $\begin{array}{l}\text { weakly to moderately depressed; very strongly } \\
\text { embracing ( } w w / w h=1.40-1.60 ; I Z R=0.45-0.50 \text { ) }\end{array}$ & $\begin{array}{l}\text { moderate } \\
(\text { WER } \sim 1.95)\end{array}$ \\
\hline $30 \mathrm{~mm}$ & $\begin{array}{l}\text { thickly pachyconic; involute } \\
\text { (ww/dm } \sim 0.75 ; \mathrm{uw} / \mathrm{dm} \sim 0.10 \text { ) }\end{array}$ & $\begin{array}{l}\text { weakly depressed; very strongly embracing } \\
\text { (ww/wh } \sim 1.40 ; \text { IZR } \sim 0.50 \text { ) }\end{array}$ & $\begin{array}{l}\text { moderate } \\
(\text { WER } \sim 1.90)\end{array}$ \\
\hline
\end{tabular}


Table 89. Conch dimensions (in $\mathrm{mm}$ ) and proportions for reference specimens of Follotites folloti $\mathrm{n}$. sp.

\begin{tabular}{lccccccccccc}
\hline & $\mathrm{dm}$ & ww & wh & uw & ah & ww/dm & ww/wh & uw/dm & WER & IZR & \\
\hline holotype MB.C.18734.1 & 34.2 & 25.2 & 18.5 & 3.8 & 9.6 & 0.74 & 1.36 & 0.11 & 1.93 & 0.48 \\
paratype MB.C.18734.2 & 27.4 & 20.0 & 14.7 & 3.1 & 7.2 & 0.73 & 1.36 & 0.11 & 1.84 & 0.51 \\
paratype MB.C.18734.3 & 23.0 & 16.6 & 12.5 & 1.8 & 6.1 & 0.72 & 1.33 & 0.08 & 1.86 & 0.51 \\
paratype MB.C.18734.5 & 19.8 & 15.2 & 10.4 & 1.4 & 5.6 & 0.77 & 1.46 & 0.07 & 1.93 & 0.47 \\
paratype MB.C.18792.1 & 15.3 & 11.9 & 9.1 & 1.0 & 4.2 & 0.78 & 1.32 & 0.07 & 1.91 & 0.53 \\
\hline
\end{tabular}

Table 90. Suture line proportions (Figs 62B-D) for Follotites folloti n. sp.

\begin{tabular}{llllllll}
\hline specimen & at dm & EL w/d & EL/VLS & EL/AL & MS h & VLS w/h & remarks \\
\hline holotype MB.C.18734.1 & c. $28.0 \mathrm{~mm}$ & 0.39 & 0.57 & 0.81 & 0.20 & 0.68 & E lobe wider at base \\
paratype MB.C.18734.2 & $21.5 \mathrm{~mm}$ & 0.36 & 0.46 & 0.64 & 0.17 & 0.79 & E lobe exactly parallel-sided \\
paratype MB.C.18734.3 & $18.1 \mathrm{~mm}$ & 0.37 & 0.52 & 0.72 & 0.20 & 0.72 & E lobe wider at base \\
\hline
\end{tabular}

Discussion. Follotites folloti differs from the other species of Follotites from the Argiles de Teguentour in the thickly discoidal and involute adult conch, which does not show steinkern constrictions.

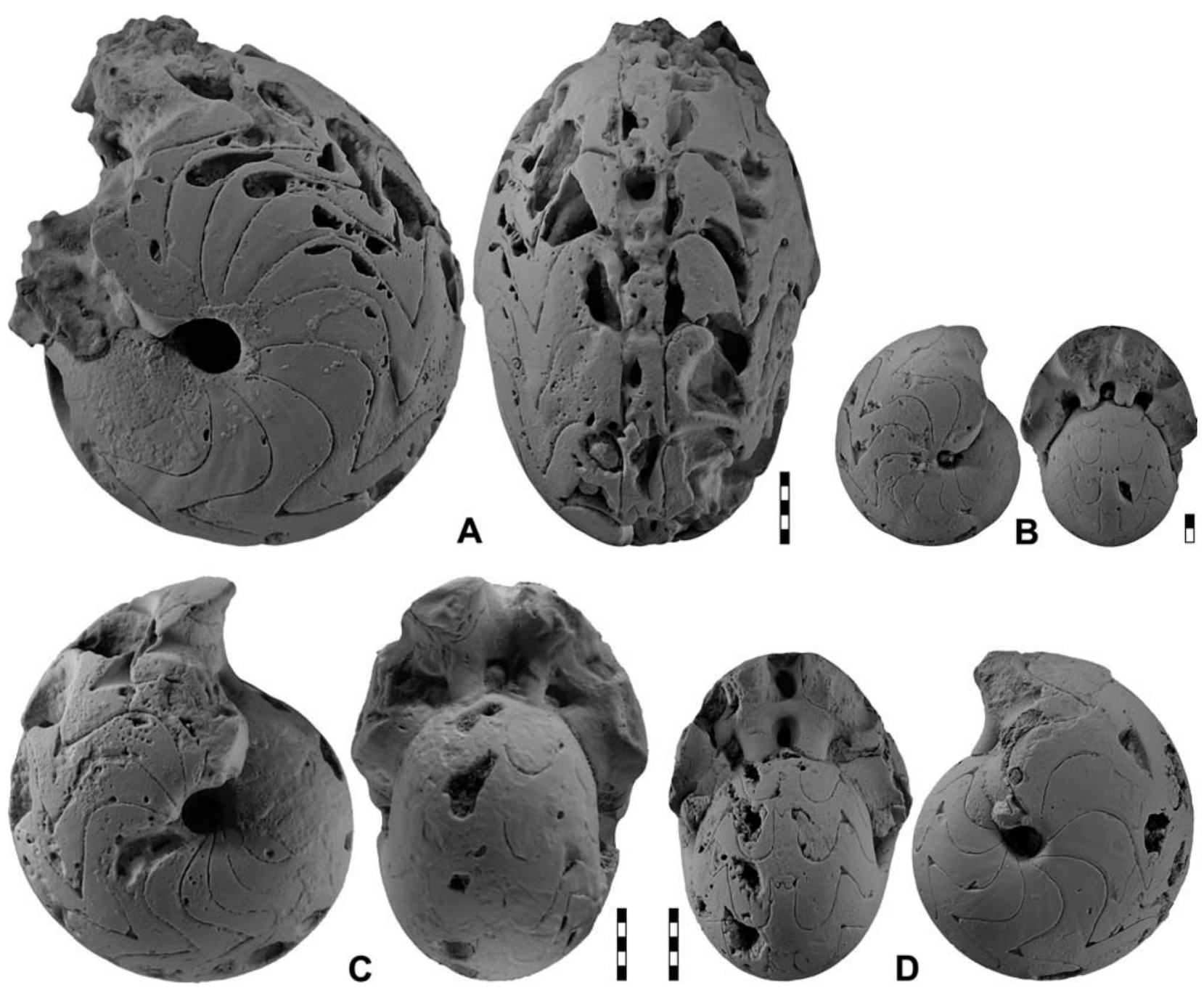

Figure 61. Follotites folloti $n$. sp.; all $\times 2$. A. Holotype MB.C.18734.1 from locality A320-5. B. Paratype MB.C.18792.1 from locality MOU-B0. C. Paratype MB.C.18734.2 from locality A320-5. D. Paratype MB.C.18734.3 from locality A320-5. 


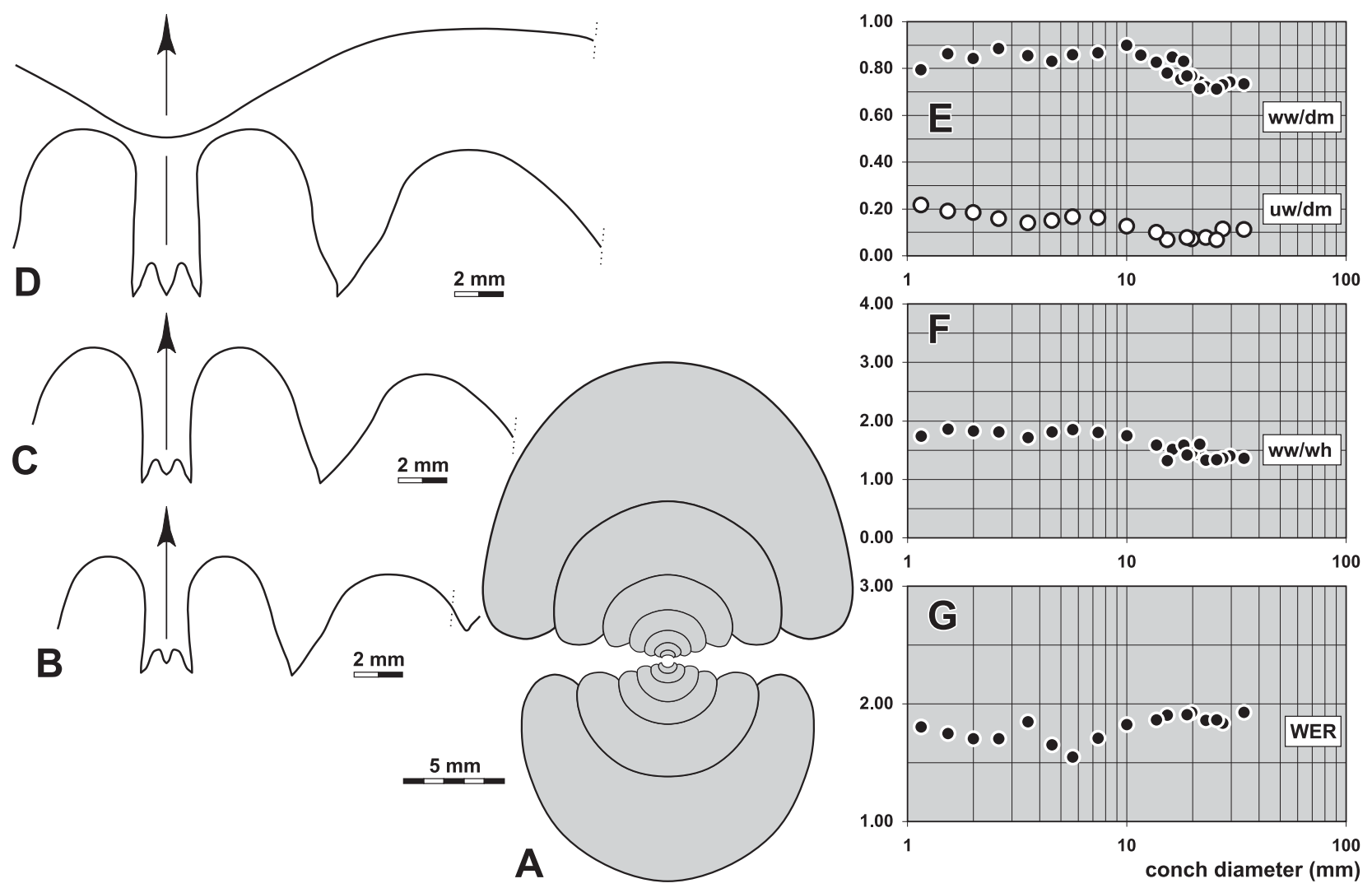

Figure 62. Follotites folloti n. sp. from locality A320-5. A. Cross section of paratype MB.C.18734.4 from locality A320-5; $\times 2.5$. B. Suture line of paratype MB.C.18734.3, at $18.1 \mathrm{~mm} \mathrm{dm}, 15.1 \mathrm{~mm} \mathrm{ww}, 10.5 \mathrm{~mm} \mathrm{wh} ; \times 3.0$. C. Suture line of paratype MB.C. 18734.2 , at $21.5 \mathrm{~mm} \mathrm{dm}, 16.6 \mathrm{~mm} \mathrm{ww}, 11.1 \mathrm{~mm} \mathrm{wh;} \times 3.0$. D. Suture line and growth line course of holotype MB.C.18734.1, at $19.6 \mathrm{~mm}$ ww, $12.6 \mathrm{~mm}$ wh; $\times 3.0 . \mathbf{E}-$ G. Ontogenetic development of the conch width index (ww/dm), umbilical width index (uw/dm), whorl width index (ww/wh), and whorl expansion rate (WER) of all available specimens.

\section{Follotites stelus n. sp.}

Figures 63, 64

Derivation of name. From Latin stelus = pillar, because of the shape of the external lobe.

Holotype. Specimen MB.C.18793.1, illustrated in Figure 63B.

Type locality and horizon. Oued Temertasset, locality and sample MOU-B6 (Mouydir, South Algeria); upper Pericyclus-Progoniatites Assemblage. Material. 22 specimens, conch diameter up to $35 \mathrm{~mm}$.

Diagnosis. Follotites with thickly pachyconic or globular conch up to $16 \mathrm{~mm} \mathrm{dm}$, thereafter transforming into a thinly pachyconic adult conch; conch involute in juveniles, becoming subinvolute at $6 \mathrm{~mm} \mathrm{dm}$; umbilical margin subangular, umbilical wall convex; aperture moderate in juveniles and low in the adult stage. Steinkern without or with very weak convex constrictions with moderately deep and wide ventral sinus. Suture line with very narrow, subparallel-sided external lobe and very low median saddle; ventrolateral saddle broadly rounded and slightly asymmetric; adventive lobe V-shaped, slightly asymmetric.

Table 91. Conch ontogeny (Figs 64A, B, D-F) of Follotites stelus n. sp.

\begin{tabular}{|c|c|c|c|}
\hline $\mathrm{dm}$ & conch shape & whorl cross section shape & aperture \\
\hline $2 \mathrm{~mm}$ & $\begin{array}{l}\text { thinly globular; involute } \\
(\mathrm{ww} / \mathrm{dm} \sim 0.85 ; \text { uw/dm } \sim 0.14)\end{array}$ & $\begin{array}{l}\text { moderately depressed; very strongly embracing } \\
(\text { ww/wh } \sim 1.70 \text {; IZR } \sim 0.50)\end{array}$ & $\begin{array}{l}\text { moderate } \\
(\text { WER } \sim 1.80)\end{array}$ \\
\hline $8 \mathrm{~mm}$ & $\begin{array}{l}\text { thinly globular; subinvolute } \\
\text { (ww/dm } \sim 0.85 ; \text { uw/dm } \sim 0.20 \text { ) }\end{array}$ & $\begin{array}{l}\text { moderately depressed; very strongly embracing } \\
\text { (ww/wh } \sim 1.90 \text {; IZR } \sim 0.50)\end{array}$ & $\begin{array}{l}\text { low } \\
\text { (WER 1.65) }\end{array}$ \\
\hline $20 \mathrm{~mm}$ & $\begin{array}{l}\text { thinly to thickly pachyconic; subinvolute } \\
\text { (ww/dm }=0.65-0.75 ; \mathrm{w} / \mathrm{dm}=0.20-0.25 \text { ) }\end{array}$ & $\begin{array}{l}\text { weakly to moderately depressed; very strongly } \\
\text { embracing ( } w w / w h=1.40-1.65 ; \text { IZR } \sim 0.50 \text { ) }\end{array}$ & $\begin{array}{l}\text { low } \\
\text { (WER 1.70) }\end{array}$ \\
\hline $30 \mathrm{~mm}$ & $\begin{array}{l}\text { thinly pachyconic; subinvolute } \\
\text { (ww/dm } \sim 0.65 ; \text { uw/dm } \sim 0.18)\end{array}$ & $\begin{array}{l}\text { weakly depressed; very strongly embracing } \\
\text { (ww/wh } \sim 1.50 ; \text { IZR } \sim 0.45)\end{array}$ & $\begin{array}{l}\text { low } \\
\text { (WER 1.70) }\end{array}$ \\
\hline
\end{tabular}


Table 92. Conch dimensions (in $\mathrm{mm}$ ) and proportions for reference specimens of Follotites stelus $\mathrm{n}$. sp.

\begin{tabular}{lccccccccccc}
\hline & $\mathrm{dm}$ & ww & wh & uw & ah & ww/dm & ww/wh & uw/dm & WER & IZR \\
\hline paratype MB.C.18769.1 & 24.3 & 15.6 & 11.1 & 5.7 & 5.9 & 0.64 & 1.40 & 0.23 & 1,75 & 0.47 \\
holotype MB.C.18793.1 & 20.9 & 15.6 & 9.5 & 4.9 & 4.7 & 0.75 & 1.65 & 0.24 & 1.67 & 0.50 \\
\hline
\end{tabular}

Table 93. Suture line proportions (Fig. 64C) for Follotites stelus n. sp.

\begin{tabular}{llllllll}
\hline specimen & at dm & EL w/d & EL/VLS & EL/AL & MS h & VLS w/h & remarks \\
\hline holotype MB.C.18793.1 & $17.5 \mathrm{~mm}$ & 0.43 & 0.64 & 0.79 & 0.18 & 0.67 & flanks of E lobe slightly incurved \\
\hline
\end{tabular}
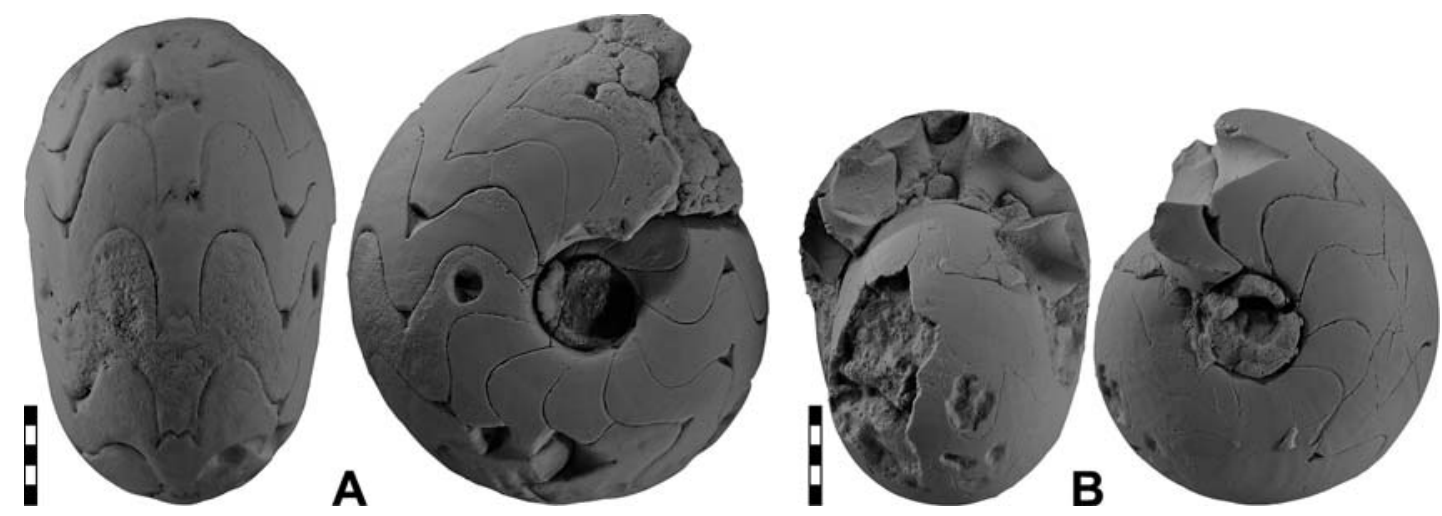

Figure 63. Follotites stelus n. sp.; all $\times 2$. A. Paratype MB.C.18769.1 from locality MOU-A. B. Holotype MB.C.18793.1 from locality MOU-B6.
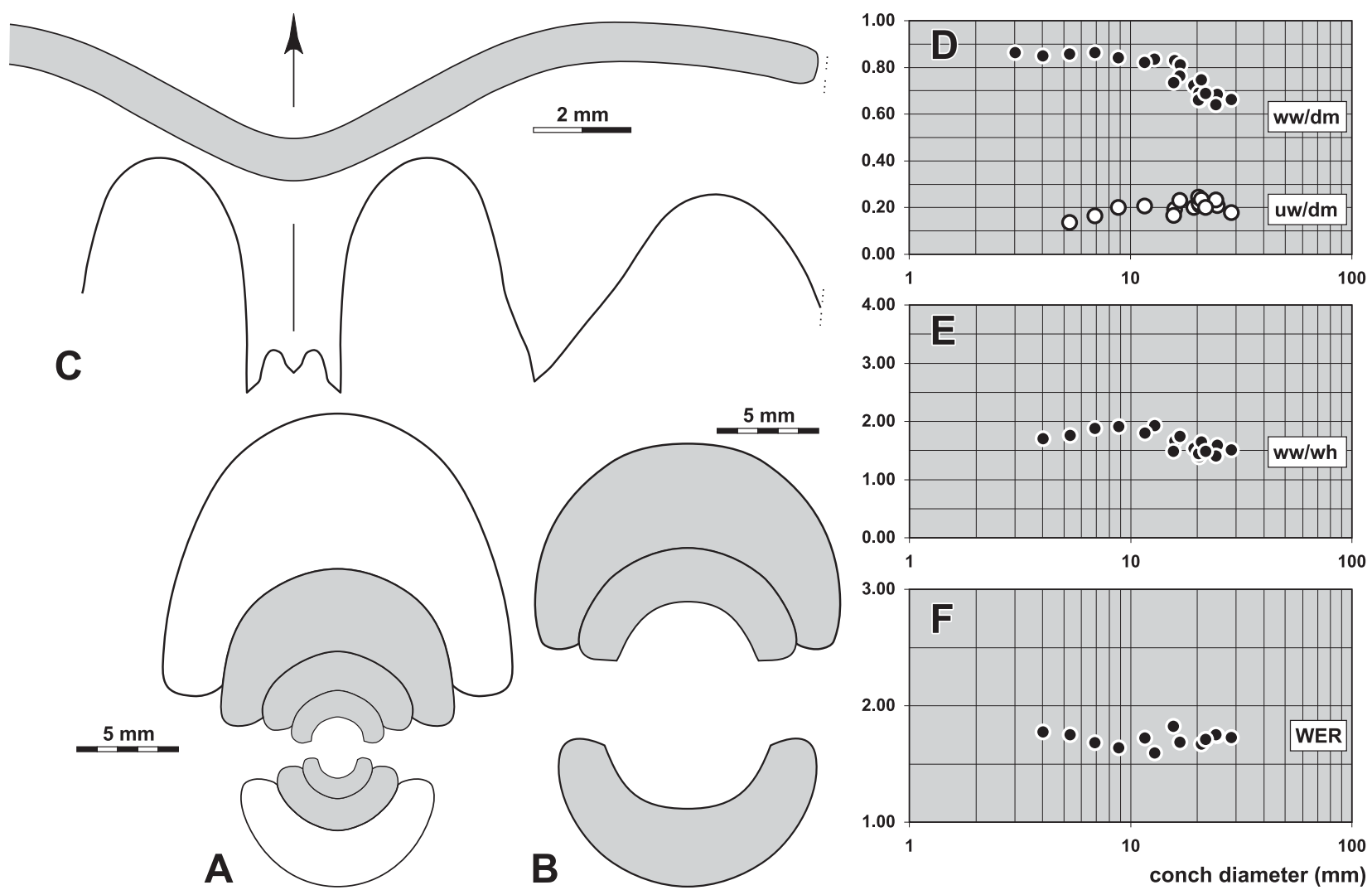

Figure 64. Follotites stelus n. sp. A. Cross section of paratype MB.C.18793.2 from locality MOU-B0; $\times 2.5$. B. Cross section of paratype MB.C.18793.3 from locality MOU-B0; $\times 2.5$. C. Suture line and constriction of holotype MB.C.18793.1 from locality MOU-B6, at $17.5 \mathrm{~mm} \mathrm{dm}, 13.9 \mathrm{~mm}$ ww, $7.9 \mathrm{~mm}$ wh; $\times 6.0$. D-F. Ontogenetic development of the conch width index (ww/dm), umbilical width index (uw/dm), whorl width index (ww/wh), and whorl expansion rate (WER) of all available specimens. 


\section{Follotites flexus n. sp.}

\section{Figures 65, 66}

Derivation of name. From Latin flexus $=$ bow, because of the wide ventral sinus of the constrictions.

Holotype. Specimen MB.C.18735.1, illustrated in Figure 65A.

Type locality and horizon. Oued Temertasset, locality and sample A320-5 (Mouydir, South Algeria); Helicocyclus-Ouaoufilalites Assemblage. Material. 13 specimens, conch diameter up to $35 \mathrm{~mm}$.

Diagnosis. Follotites with thickly pachyconic or globular conch up to $12 \mathrm{~mm} \mathrm{dm}$, thereafter transforming into a thinly pachyconic adult conch; conch involute with a subinvolute interval between 5 and $20 \mathrm{~mm} \mathrm{dm}$; umbilical margin narrowly rounded, umbilical wall convex; aperture moderately high throughout ontogeny. Steinkern with very weak concavo-convex constrictions with low and wide ventral sinus. Suture line with very narrow, subparallel-sided external lobe and very low median saddle; ventrolateral saddle broadly rounded and slightly asymmetric; adventive lobe V-shaped, slightly asymmetric.

Table 94. Conch ontogeny (Figs 66A, B, D-F) of Follotites flexus n. sp.

\begin{tabular}{llll}
\hline $\mathrm{dm}$ & conch shape & whorl cross section shape & aperture \\
\hline $2 \mathrm{~mm}$ & thinly globular; involute & moderately depressed; very strongly embracing & moderate \\
& $($ ww/dm $\sim 0.90 ;$ uw/dm $\sim 0.14)$ & $($ ww/wh $\sim 1.80 ;$ IZR $\sim 0.50)$ & $($ WER $\sim 1.80)$ \\
$8 \mathrm{~mm}$ & thinly globular; subinvolute & strongly depressed; very strongly embracing & moderate \\
& $($ ww/dm $\sim 0.90 ;$ uw/dm $\sim 0.25)$ & $($ ww/wh $\sim 2.05 ;$ IZR $\sim 0.50)$ & $($ WER $\sim 1.80)$ \\
$20 \mathrm{~mm}$ & thinly pachyconic; subinvolute & weakly depressed; very strongly embracing & moderate \\
& $($ ww/dm = 0.64-0.73; uw/dm $=0.15-0.20)$ & $($ ww/wh $=1.20-1.45 ;$ IZR $\sim 0.50)$ & $($ WER $\sim 1.80)$ \\
$30 \mathrm{~mm}$ & thinly pachyconic; involute & weakly depressed; very strongly embracing & moderate \\
& $($ ww/dm $\sim 0.65 ;$ uw/dm $\sim 0.10)$ & $($ ww/wh $\sim 1.25 ;$ IZR $\sim 0.50)$ & $($ WER $\sim 1.90)$
\end{tabular}

Table 95. Conch dimensions (in $\mathrm{mm}$ ) and proportions for reference specimens of Follotites flexus $\mathrm{n}$. sp.

\begin{tabular}{llllllllllll}
\hline & $\mathrm{dm}$ & ww & wh & uw & ah & ww/dm & ww/wh & uw/dm & WER & IZR \\
\hline paratype MB.C.18735.5 & 34.7 & 22.3 & 18.7 & 3.7 & 9.1 & 0.64 & 1.19 & 0.11 & 1.84 & 0.51 \\
paratype MB.C.18735.6 & 23.9 & 15.2 & 12.1 & 3.3 & 6.0 & 0.64 & 1.25 & 0.14 & 1.79 & 0.50 \\
holotype MB.C.18735.1 & 23.7 & 15.6 & 12.9 & 3.5 & 6.8 & 0.66 & 1.21 & 0.15 & 1.96 & 0.48 \\
\hline
\end{tabular}

Table 96. Suture line proportions (Fig. 66C) for Follotites flexus n. sp.

\begin{tabular}{llllllll}
\hline specimen & at dm & EL w/d & EL/VLS & EL/AL & MS h & VLS w/h & remarks \\
\hline holotype MB.C.18735.1 & c. $16.0 \mathrm{~mm}$ & 0.38 & 0.52 & 0.89 & 0.20 & 0.73 & flanks of E lobe slightly incurved \\
\hline
\end{tabular}

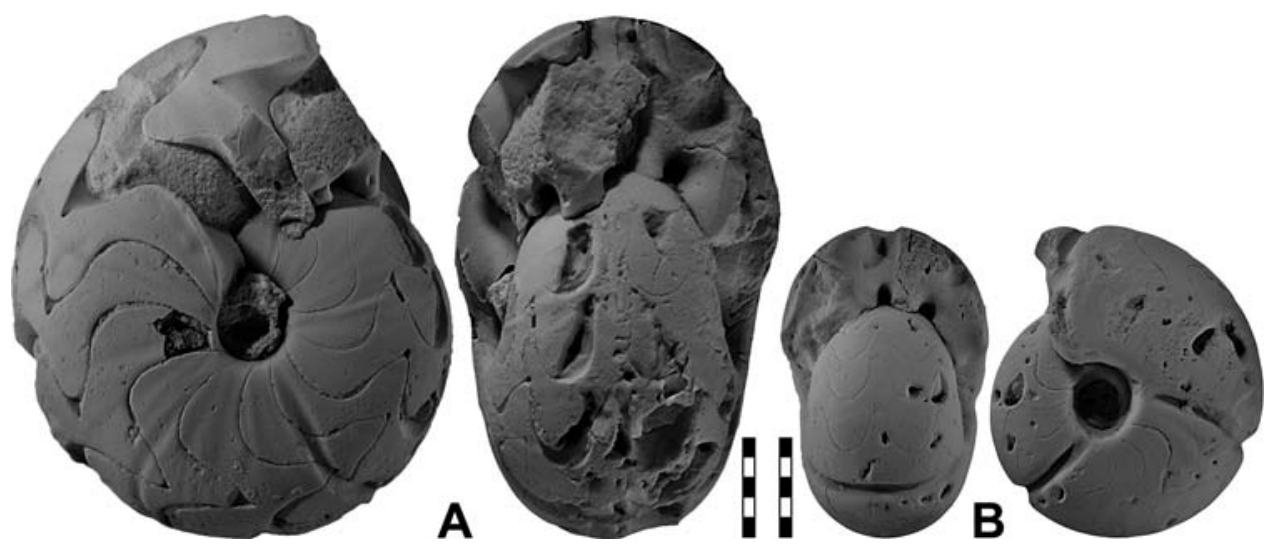

Figure 65. Follotites flexus n. sp. from locality A3205; all $\times 2$. A. Holotype MB.C.18735.1. B. Paratype MB.C.18735.2. 

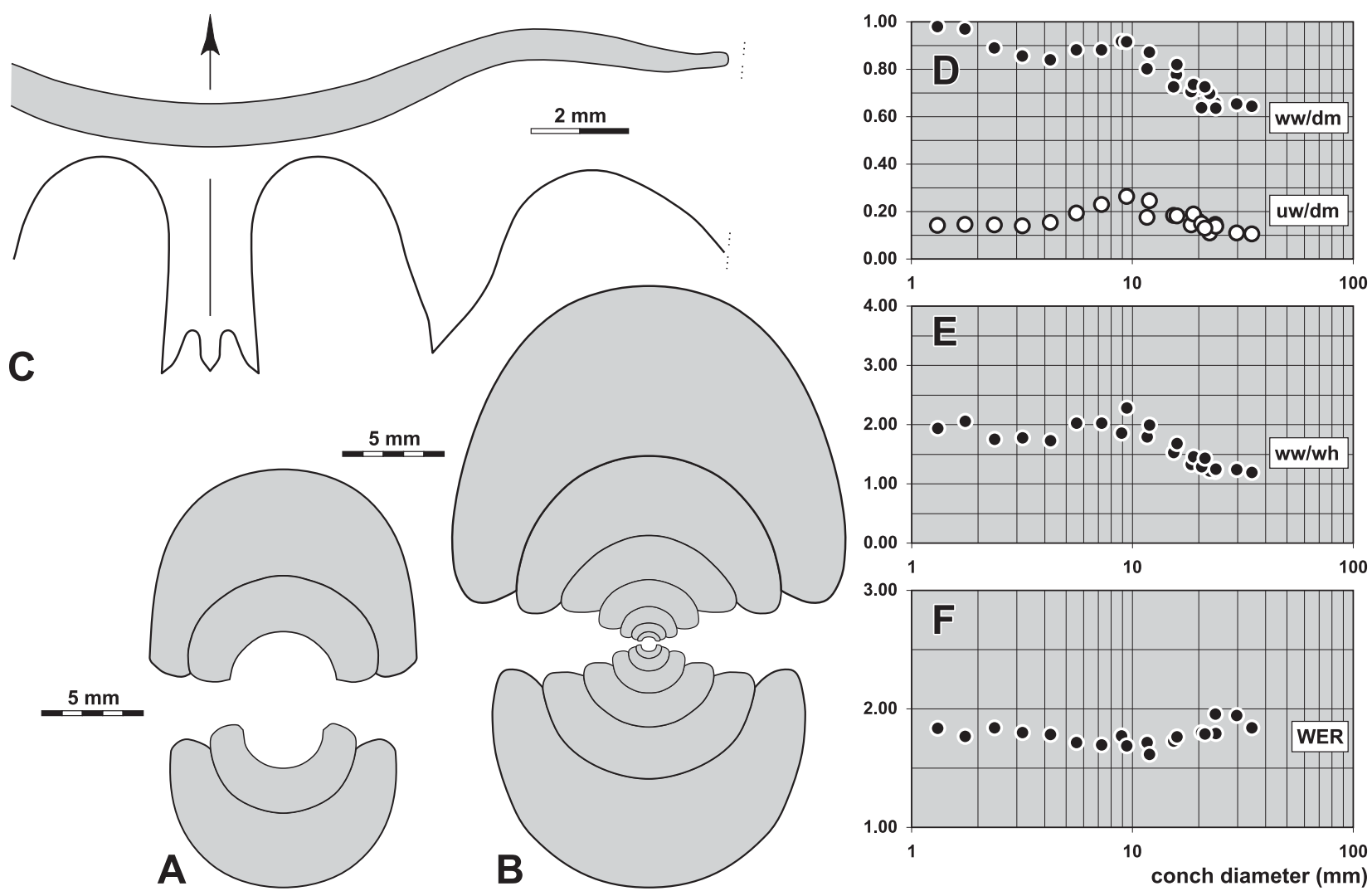

Figure 66. Follotites flexus n. sp. A. Cross section of paratype MB.C.18735.3 from locality A320-5; $\times 2.5$. B. Cross section of paratype MB.C.18735.4 from locality A320-5; $\times 2.5$. C. Suture line and constriction of holotype MB.C.18735.1 from locality A320-5, at $11.5 \mathrm{~mm}$ ww, $8.5 \mathrm{~mm}$ wh; $\times 6.0$. D-F. Ontogenetic development of the conch width index (ww/dm), umbilical width index (uw/dm), whorl width index (ww/wh), and whorl expansion rate (WER) of all available specimens.

Family Rotopericyclidae n. fam.

Family definition. Pericyclaceae with a conch ontogeny that includes an increase of the uw/dm ratio, beginning in the adult stage and progressing onto juveniles. Suture line with parallel-sided or V-shaped external lobe with subparallel flanks.

Included subfamilies.

Rotopericyclinae n. subfam.

Trimorphoceratinae Ebbighausen, Korn \& Bockwinkel, 2010

Discussion. The spectrum of characters of the new family suggests that it derived from the family Muensteroceratidae by the modification of the conch ontogeny. While the conch ontogeny in the Muensteroceratidae is rather simple with a more or less stable umbilical width, an almost continuous decrease of the ww/dm and ww/wh ratio, and an almost continuous increase of the whorl expansion rate, it is much more complex in the Rotopericyclidae.

\section{Subfamily Rotopericyclinae n. subfam.}

Subfamily definition. Rotopericyclidae with a conch ontogeny that includes an increase of the uw/dm ratio in the intermediate or adult stage, without significant re-closure of the umbilicus in the adult stage.

Included genera.

Eurites Kusina, 1973

Mouydiria n. gen.

Rotopericyclus Turner, 1948

Rhnetites Bockwinkel, Korn \& Ebbighausen, 2010

Parahammatocyclus Riley, 1996

Discussion. The members of the subfamily differ from the subfamily Trimorphoceratinae in the lack of an adult stage with re-closure of the umbilicus. 


\section{Eurites Kusina, 1973}

Type species. Eurites latus Kusina, 1973 (OD).

Genus definition. Rotopericyclidae with significant ontogenetic changes in the conch; shape pachyconic or globular, involute or subinvolute in juveniles and the adult stage, intermediate stage with striking opening of the umbilicus; flanks and venter broadly rounded with $\mathrm{C}$-shaped whorl cross section; umbilical wall often flattened, umbilical margin narrowly rounded or subangular. Ornament with very fine, concavo-convex rectiradiate growth-lines with subangular ventrolateral projection and rather deep ventral sinus; often with shell constrictions parallel to the growth lines. Suture line with very narrow, parallel-sided external lobe and very low or low median saddle; ventrolateral saddle broadly rounded; adventive lobe V-shaped, symmetric or slightly asymmetric.

Included species.

commutatus: Eurites commutatus Ebbighausen, Korn \& Bockwinkel, 2010; Gourara, Algeria.

corpulentissimus: Münsteroceras corpulentissimum Schindewolf, 1951: 65. Harz.

corpulentus: Glyphioceras corpulentum Crick, 1899: 447. Ireland.

doliaris: Eurites doliaris n. sp.; Mouydir, Algeria.

ellipsoidalis: Glyphioceras ellipsoidale Crick, 1899: 499. Ireland.

inflatus: Munsteroceras inflatum Delépine, 1940: 53. Belgium.

kusinae: Eurites kusinae Work \& Nassichuk, 2000: 41. British Columbia.

latus: Eurites latus Kusina, 1973: 22. North Urals.

obesus: Glyphioceras (Beyrichoceras) obesum Foord, 1903: 198. Ireland.

permutus: Eurites permutus n. sp.; Mouydir, Algeria.

pondus: Eurites pondus Ebbighausen, Korn \& Bockwinkel, 2010; Gourara, Algeria.

saginatus: Münsteroceras saginatum Gordon, 1957: 35. Alaska.

? browni: Goniatites Browni M'Coy, 1844: 12. Ireland.

Separation of the new species. The two species of Eurites from Oued Temertasset can be separated by means of conch morphology and the suture line. In the conch ontogeny, they can be distinguished as follows:

- E. permutus - the uw/dm ratio decreases almost continuously from 0.20 at $2 \mathrm{~mm} \mathrm{dm}$ to $0.13-0.20$ at $5 \mathrm{~mm}$ dm, thereafter an increase to $0.17-0.26$ takes place until $20 \mathrm{~mm} \mathrm{dm}$; the ww/dm ratio decreases from $0.77-0.85$ at $2 \mathrm{~mm} \mathrm{dm}$ to $0.54-0.68 \mathrm{at} 20 \mathrm{~mm} \mathrm{dm}$.

- E. doliaris - the uw/dm ratio increases almost continuously from 0.20 at $2 \mathrm{~mm} \mathrm{dm}$ to 0.30 at $20 \mathrm{~mm} \mathrm{dm}$; the ww/dm ratio decreases, during the same interval, continuously from $0.80-0.90$ to $0.70-0.75$.

The suture line offers more differences:

- E. permutus - the external lobe has parallel flanks.

- E. doliaris - the external lobe has slightly incurved flanks; the adventive lobe is almost symmetric.

Discussion. The ontogenetic development of the species within the genus Eurites is known in great detail only from the two new Algerian species, and hence it is not clear if all the listed species in fact belong to this genus. A species that shows the ontogenetic loop with temporary opening of the umbilicus is E. corpulentissimus (Schindewolf, 1951), which, according to the figures and measurement list provided by Schindewolf(1951), resembles the Algerian species.

The type species E. latus Kusina, 1973 from the North Urals possesses a clear trend of strong umbilical opening during intervals of its ontogeny, but a closure of the umbilicus cannot be seen.

\section{Eurites permutus n. sp.}

Figures 67, 68

Derivation of name. From Latin permutus = change, because of the significant ontogenetic changes.

Holotype. Specimen MB.C.19040.1, illustrated in Figure 67A.

Type locality and horizon. Oued Temertasset, locality and sample MOU-X (Mouydir, South Algeria); Helicocyclus-Ouaoufilalites Assemblage. Material. 383 specimens, conch diameter up to $44 \mathrm{~mm}$.

Diagnosis. Eurites with thickly pachyconic conch in the early juvenile stage, becoming more slender during ontogeny and being thickly discoidal at $20 \mathrm{~mm} \mathrm{dm}$; conch subinvolute throughout ontogeny with an involute interval between 3 and $7 \mathrm{~mm}$ dm; umbilical margin subangular, umbilical wall steep; aperture low or moderate throughout ontogeny. Steinkern with concavo-convex, prorsiradiate constrictions with moderately high ventrolateral projection and moderately deep ventral sinus. Suture line with very narrow, parallel-sided external lobe and very low or low median saddle; ventrolateral saddle almost symmetric, broadly rounded; adventive lobe V-shaped, symmetric or asymmetric.

Table 97. Conch ontogeny (Figs 68A-D, H-J) of Eurites permutus n. sp.

\begin{tabular}{|c|c|c|c|}
\hline $\mathrm{dm}$ & conch shape & whorl cross section shape & aperture \\
\hline $2 \mathrm{~mm}$ & $\begin{array}{l}\text { thickly pachyconic; subinvolute } \\
\text { (ww/dm }=0.78-0.85 ; \text { uw/dm } \sim 0.20 \text { ) }\end{array}$ & $\begin{array}{l}\text { moderately depressed; very strongly embracing } \\
\text { (ww/wh } \sim 1.65 ; \text { IZR }=0.45-0.50 \text { ) }\end{array}$ & $\begin{array}{l}\text { low to moderate } \\
(\mathrm{WER}=1.60-1.80)\end{array}$ \\
\hline $8 \mathrm{~mm}$ & $\begin{array}{l}\text { thickly pachyconic; involute or subinvolute } \\
\text { (ww/dm }=0.70-0.80 ; u w / d m=0.10-0.25 \text { ) }\end{array}$ & $\begin{array}{l}\text { weakly to moderately depressed; very strongly embracing } \\
\text { (ww/wh }=1.25-1.75 ; \mathrm{IZR}=0.45-0.50 \text { ) }\end{array}$ & $\begin{array}{l}\text { low to moderate } \\
(\text { WER }=1.70-2.00)\end{array}$ \\
\hline $20 \mathrm{~mm}$ & $\begin{array}{l}\text { thickly discoidal to thinly pachyconic; subinvolute } \\
\text { (ww/dm }=0.54-0.68 ; u w / d m=0.15-0.25 \text { ) }\end{array}$ & $\begin{array}{l}\text { weakly to moderately depressed; strongly embracing } \\
\text { (ww/wh }=1.20-1.60 ; \text { IZR }=0.40-0.45 \text { ) }\end{array}$ & $\begin{array}{l}\text { low to moderate } \\
(\mathrm{WER}=1.70-1.90)\end{array}$ \\
\hline
\end{tabular}


Table 98. Conch dimensions (in $\mathrm{mm}$ ) and proportions for reference specimens of Eurites permutus n. sp.

\begin{tabular}{lrrrrrrrrrr}
\hline & dm & ww & wh & uw & ah & ww/dm & ww/wh & uw/dm & WER & IZR \\
\hline holotype MB.C.19040.1 & 19.8 & 12.8 & 9.1 & 4.2 & 4.9 & 0.65 & 1.41 & 0.21 & 1.77 & 0.46 \\
paratype MB.C.18993.1 & 17.3 & 11.9 & 8.5 & 3.6 & 4.2 & 0.69 & 1.40 & 0.21 & 1.73 & 0.51 \\
paratype MB.C.18978.1 & 14.0 & 10.5 & 7.0 & 3.1 & 3.5 & 0.75 & 1.49 & 0.22 & 1.78 & 0.50 \\
paratype MB.C.18835.1 & 11.1 & 8.0 & 5.4 & 2.4 & 2.9 & 0.72 & 1.48 & 0.22 & 1.82 & 0.47 \\
paratype MB.C.19040.2 & 7.7 & 5.9 & 3.4 & 1.7 & 1.8 & 0.77 & 1.76 & 0.23 & 1.72 & 0.46 \\
\hline
\end{tabular}
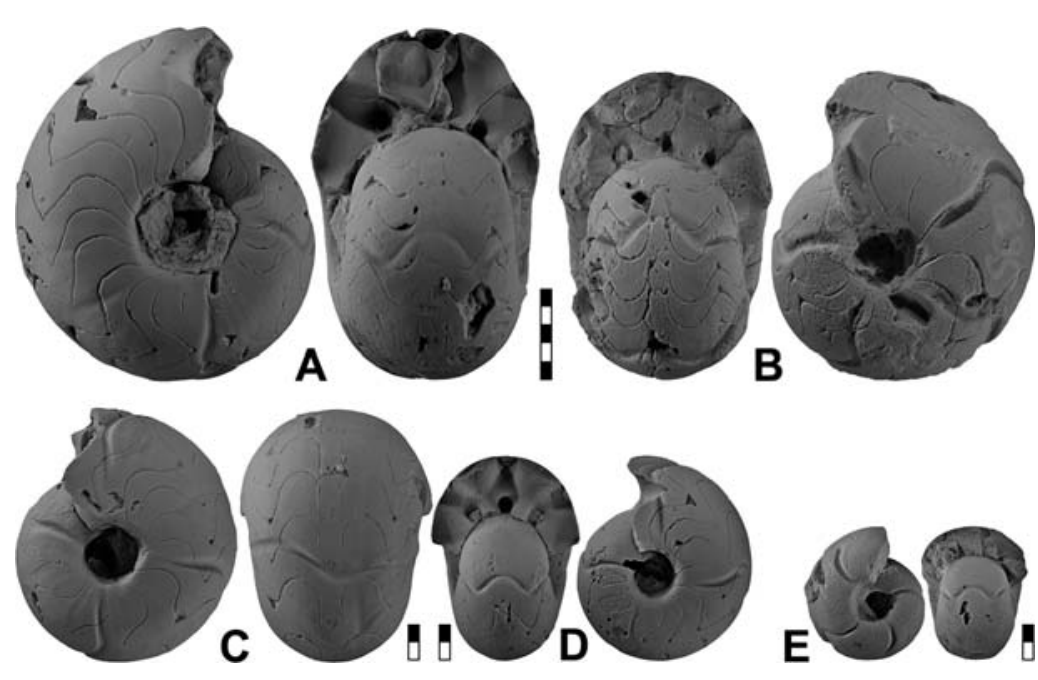

Figure 67. Eurites permutus n. sp.; all $\times 2$. A. Holotype MB.C.19040.1 from locality MOU-X. B. Paratype MB.C.18993.1 from locality MOU-E12. C. Paratype MB.C.18978.1 from locality MOU-E10. D. Paratype MB.C.18835.1 from locality MOU-C5. E. Paratype MB.C.19040.2 from locality MOU-X.

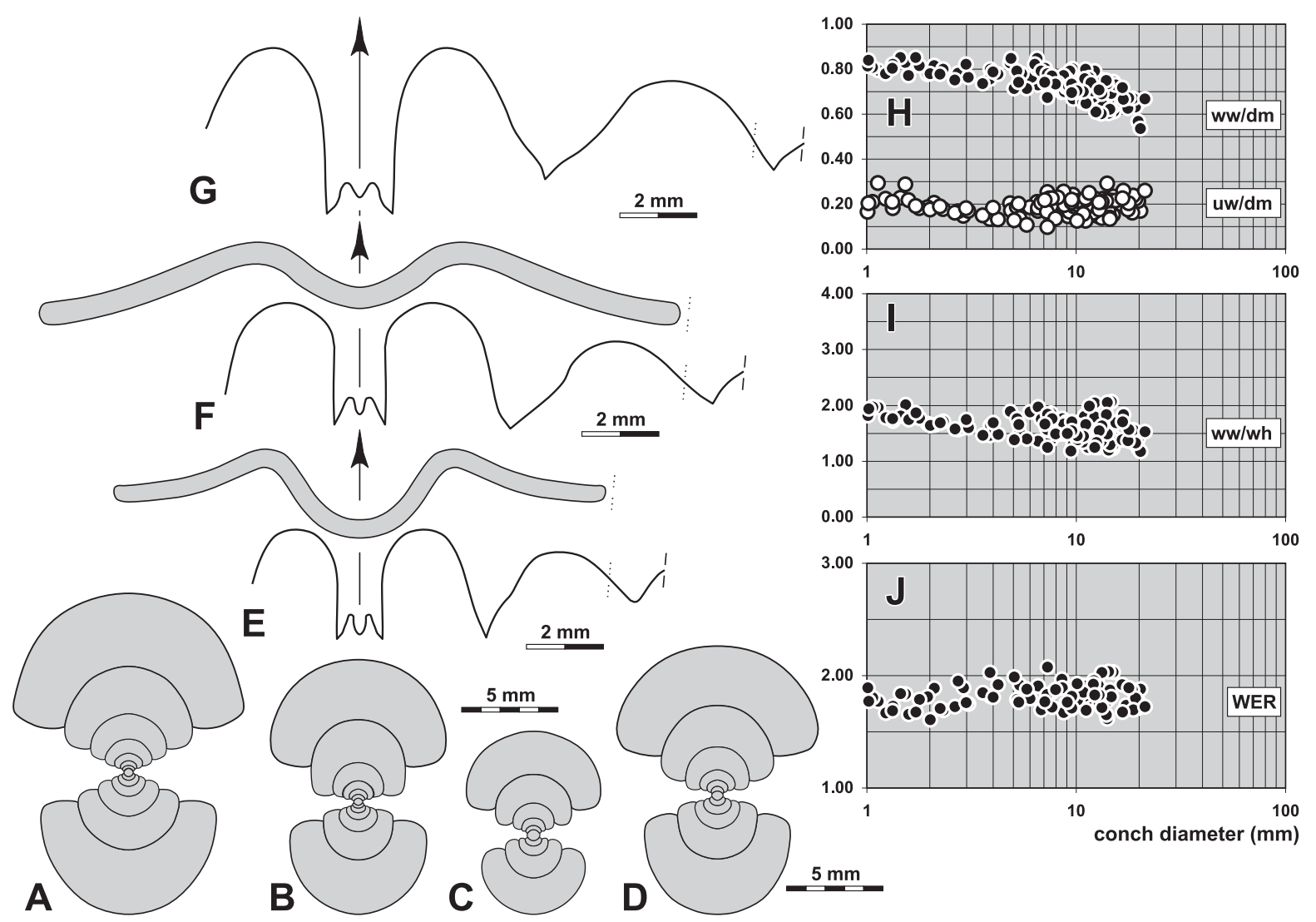

Figure 68. Eurites permutus n. sp. A. Cross section of paratype MB.C.18849.1 from locality MOU-C4 $+5 ; \times 2.5$. B. Cross section of paratype MB.C.19040.3 from locality MOU-X; $\times 2.5$. C. Cross section of paratype MB.C.19040.4 from locality MOU-X; $\times 2.5$. D. Cross section of paratype MB.C.19040.5 from locality MOU-X; $\times 2.5$. E. Suture line and constriction of paratype MB.C.18835.1 from locality MOU-C5, at $11.0 \mathrm{~mm} \mathrm{dm}, 7.9 \mathrm{~mm}$ ww, $5.3 \mathrm{~mm}$ wh; $\times 5.0$. F. Suture line and constriction of paratype MB.C.18978.1 from locality MOU-E12, at $14.0 \mathrm{~mm} \mathrm{dm}, 10.4 \mathrm{~mm}$ ww, $7.0 \mathrm{~mm}$ wh; $\times 5.0$. G. Suture line of holotype MB.C.19040.1 from locality MOU-X, at $19.0 \mathrm{~mm} \mathrm{dm}, 12.5 \mathrm{~mm}$ ww, $9.0 \mathrm{~mm}$ wh; $\times 5.0$. H-J. Ontogenetic development of the conch width index (ww/dm), umbilical width index (uw/dm), whorl width index (ww/wh), and whorl expansion rate (WER) of all available specimens. 
Table 99. Suture line proportions (Figs $68 \mathrm{E}-\mathrm{G}$ ) for Eurites permutus n. sp.

\begin{tabular}{llllllll}
\hline specimen & at dm & EL w/d & EL/VLS & EL/AL & MS h & VLS w/h & remarks \\
\hline holotype MB.C.19040.1 & $19.0 \mathrm{~mm}$ & 0.44 & 0.62 & 0.68 & 0.18 & 0.71 & A lobe very wide, symmetric \\
paratype MB.C.18978.1 & $14.0 \mathrm{~mm}$ & 0.42 & 0.50 & 0.62 & 0.22 & 0.84 & A lobe asymmetric \\
paratype MB.C.18835.1 & $11.0 \mathrm{~mm}$ & 0.40 & 0.52 & 0.89 & 0.22 & 0.78 & A lobe V-shaped, narrow \\
\hline
\end{tabular}

Discussion. Eurites permutus can be regarded as one of the earliest species of the genus, where the opening rate of the umbilicus is rather low. However, the cross sections show the trend towards opening of the umbilicus, and hence, the new species is attributed to Eurites.

\section{Eurites doliaris n. sp.}

Figures 69, 70

Derivation of name. From Latin doliaris = barrel-like (or barrel-shaped), because of the conch shape.

Holotype. Specimen MB.C.18994, illustrated in Figure 69A.

Type locality and horizon. Oued Temertasset, locality and sample MOU-E12 (Mouydir, South Algeria); Helicocyclus-Ouaoufilalites Assemblage. Material. 90 specimens, conch diameter up to $37 \mathrm{~mm}$.

Diagnosis. Eurites with thickly pachyconic or globular conch in early juveniles, becoming slowly more slender during ontogeny; conch subinvolute in the juvenile stage and subevolute at $20 \mathrm{~mm} \mathrm{dm}$; umbilical margin subangular, umbilical wall rounded; aperture low or moderate throughout ontogeny. Steinkern with concavo-convex, prorsiradiate constrictions with moderately high ventrolateral projection and deep ventral sinus. Suture line with very narrow, parallel-sided external lobe with slightly incurved flanks and very low or low median saddle; ventrolateral saddle slightly asymmetric, broadly rounded; adventive lobe V-shaped with weakly curved flanks.

Table 100. Conch ontogeny (Figs 70A-C, F-H) of Eurites doliaris n. sp.

\begin{tabular}{|c|c|c|c|}
\hline$d m$ & conch shape & whorl cross section shape & aperture \\
\hline $2 \mathrm{~mm}$ & $\begin{array}{l}\text { thickly pachyconic to thinly globular; subinvolute } \\
\text { (ww/dm }=0.80-0.90 ; \mathrm{uw} / \mathrm{dm} \sim 0.20 \text { ) }\end{array}$ & $\begin{array}{l}\text { moderately depressed; very strongly embracing } \\
(\mathrm{ww} / \mathrm{wh}=1.80-2.00 ; \mathrm{IZR}=0.45-0.50)\end{array}$ & $\begin{array}{l}\text { low } \\
(\text { WER } \sim 1.70)\end{array}$ \\
\hline $8 \mathrm{~mm}$ & $\begin{array}{l}\text { thickly pachyconic to thinly globular; subinvolute to } \\
\text { subevolute } \\
\text { (ww/dm }=0.72-0.88 ; \text { uw/dm }=0.20-0.35 \text { ) }\end{array}$ & $\begin{array}{l}\text { moderately to strongly depressed; strongly to very } \\
\text { strongly embracing } \\
\text { (ww/wh }=1.75-2.25 ; \mathrm{IZR}=0.40-0.50 \text { ) }\end{array}$ & $\begin{array}{l}\text { low to moderate } \\
(\mathrm{WER}=1.60-1.85)\end{array}$ \\
\hline $20 \mathrm{~mm}$ & $\begin{array}{l}\text { thinly to thickly pachyconic; subevolute } \\
\text { (ww/dm }=0.65-0.75 ; u w / d m=0.30-0.35)\end{array}$ & $\begin{array}{l}\text { moderately depressed; strongly embracing } \\
(\mathrm{ww} / \mathrm{wh}=1.50-2.00 ; \mathrm{IZR}=0.40-0.45)\end{array}$ & $\begin{array}{l}\text { low } \\
(\text { WER } \sim 1.70)\end{array}$ \\
\hline
\end{tabular}

Table 101. Conch dimensions (in $\mathrm{mm}$ ) and proportions for reference specimens of Eurites doliaris n. sp.

\begin{tabular}{|c|c|c|c|c|c|c|c|c|c|c|}
\hline & $\mathrm{dm}$ & wW & wh & uw & ah & $w w / d m$ & ww/wh & $\mathrm{uw} / \mathrm{dm}$ & WER & IZR \\
\hline holotype MB.C.18994 & 11.4 & 8.8 & 4.7 & 3.4 & 2.7 & 0.78 & 1.87 & 0.30 & 1.74 & 0.42 \\
\hline paratype MB.C.19041.1 & 10.7 & 8.1 & 4.4 & 2.9 & 2.8 & 0.76 & 1.84 & 0.27 & 1.85 & 0.36 \\
\hline paratype MB.C.18815.1 & 10.1 & 8.5 & 3.8 & 3.3 & 2.4 & 0.84 & 2.22 & 0.33 & 1.72 & 0.37 \\
\hline paratype MB.C.19041.2 & 9.9 & 7.7 & 4.2 & 3.0 & 2.3 & 0.78 & 1.84 & 0.30 & 1.70 & 0.45 \\
\hline
\end{tabular}

Table 102. Suture line proportions (Figs 70D, E) for Eurites doliaris n. sp.

\begin{tabular}{llllllll}
\hline specimen & at dm & EL w/d & EL/VLS & EL/AL & MS h & VLS w/h & remarks \\
\hline holotype MB.C.18994 & $11.4 \mathrm{~mm}$ & 0.43 & 0.57 & 0.87 & 0.25 & 0.76 & A lobe shallow \\
paratype MB.C.18815.1 & $10.5 \mathrm{~mm}$ & 0.46 & 0.49 & 0.86 & 0.19 & 0.94 & A lobe very deep \\
\hline
\end{tabular}

Discussion. Eurites doliaris differs from E. commutatus of the Dalle à Merocanites in the constant increase of the $\mathrm{uw} / \mathrm{dm}$ ratio and the decrease of the ww/dm rate above $15 \mathrm{~mm} \mathrm{dm}$ (increasing in E. commutatus). E. pondus has also a rather constant increase of the uw/dm ratio, but differs in the angular umbilical margin and the wider conch. A comparison is difficult because of the significant size difference between the two occurrences; the largest specimens of E. doliaris reach only $23 \mathrm{~mm}$ in conch diameter, whereas E. commutatus and E. pondus specimens have diameters measuring up to three times larger. 

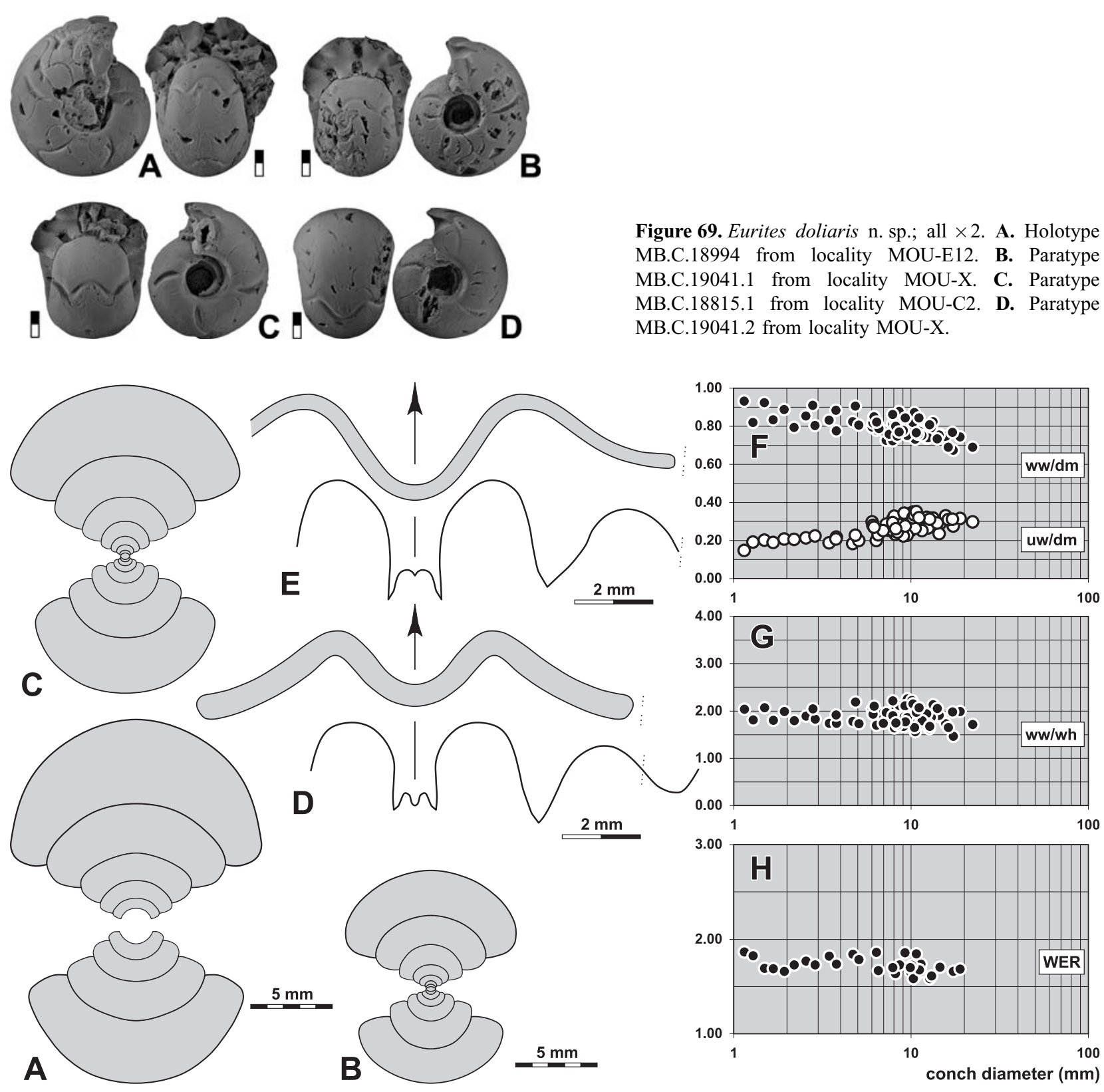

Figure 70. Eurites doliaris n. sp. A. Cross section of paratype MB.C. 18850.1 from locality MOU-C4+5; $\times 2.5$. B. Cross section of paratype MB.C.18987 from locality MOU-E11; ×2.5. C. Cross section of paratype MB.C.19041.3 from locality MOU-X; $\times 2.5$. D. Suture line and constriction of paratype MB.C.18815.1 from locality MOU-C2, at $11.5 \mathrm{~mm} w w, 8.5 \mathrm{~mm}$ wh; $\times 6.0$. E. Suture line and constriction of holotype MB.C.18994 from locality MOU-E12, at $11.5 \mathrm{~mm} w w, 8.5 \mathrm{~mm}$ wh; $\times 6.0$. F-H. Ontogenetic development of the conch width index (ww/dm), umbilical width index (uw/dm), whorl width index (ww/wh), and whorl expansion rate (WER) of all available specimens.

\section{Mouydiria n. gen.}

Derivation of name. After the type region.

Type species. Mouydiria mouydirensis $\mathrm{n}$. sp.

Genus definition. Rotopericyclidae with rather small, pachyconic or thickly discoidal conch, reaching a conch diameter of up to $50 \mathrm{~mm}$. Early whorls subinvolute, ontogenetic opening of the umbilicus to form a subevolute conch. Steinkern with prominent convex or almost linear constrictions; rounded nodes on the umbilical margin. Suture line with parallel-sided, very narrow external lobe (EL w/d $=0.40-0.50 ; \mathrm{EL} / \mathrm{AL}$ $=0.80-1.00$ ) and very low median saddle (MS $\mathrm{h}=0.15-0.20$ ); ventrolateral saddle broadly rounded, nearly symmetric; adventive lobe $\mathrm{V}$ shaped, symmetric or asymmetric.

Included species.

bouhamedensis: Eurites bouhamedensis Korn, Bockwinkel, Ebbighausen \& Klug, 2003, p. 83; Anti-Atlas, Morocco. mouydirensis: Mouydiria mouydirensis n. sp.; Mouydir, Algeria.

scutula: Mouydiria scutula n. sp.; Mouydir, Algeria. 
Separation of the new species. The two species of Mouydiria from Oued Temertasset can be separated by means of conch morphology and the suture line. In the conch ontogeny, they can be distinguished as follows:

- M. mouydirensis - the uw/dm ratio remains, between 1 and $7 \mathrm{~mm} \mathrm{dm}$, stable at $0.20-0.24$, followed by an increase to 0.40 at $30 \mathrm{~mm}$ dm; the ww/wh ratio is stable throughout ontogeny at a value of 1.60-1.80 (with intraspecific variability).

- M. scutula - the uw/dm ratio continuously increases from 0.20 at $1.3 \mathrm{~mm} \mathrm{dm}$ to 0.40 at $9.5 \mathrm{~mm}$ dm; followed by a decrease to 0.30 at $24 \mathrm{~mm} \mathrm{dm}$; the ww/wh ratio increase to a value of 2.50 at $9 \mathrm{~mm}$ dm and thereafter decreases to $1.60 \mathrm{at} 24 \mathrm{~mm} \mathrm{dm}$.

The suture line offers more differences:

- M. mouydirensis - the external lobe has parallel flanks; the adventive lobe is asymmetric with a steep ventral flank and a curved dorsal flank.

- M. scutula - the external lobe has slightly incurved flanks; the adventive lobe is symmetric.

Discussion. Mouydiria is closely related to Eurites, but a number of differences justify the separation. The course of growth lines and constrictions differs markedly; they extend almost linear with a very wide and shallow ventral sinus in Mouydiria, but form a prominent ventrolateral projection and a narrow and deep ventral sinus in Eurites.

\section{Mouydiria mouydirensis n. sp.}

Figures 71,72

Derivation of name. After the type region.

Holotype. Specimen MB.C.18736.1, illustrated in Figure 71A.

Type locality and horizon. Oued Temertasset, locality and sample A320-5 (Mouydir, South Algeria); Helicocyclus-Ouaoufilalites Assemblage. Material. 30 specimens, conch diameter up to $31 \mathrm{~mm}$.

Diagnosis. Mouydiria with thickly pachyconic and subinvolute conch up to $7 \mathrm{~mm}$ in $\mathrm{dm}$, thereafter transformation into a thickly discoidal and subevolute adult conch; umbilical margin narrowly rounded or subangular, umbilical wall steep, flattened; aperture moderate in juveniles and low in the adult stage. Steinkern with wide and deep, convex constrictions with very shallow and wide ventral sinus; umbilical margin with rounded nodes or short riblets in the intermediate growth interval. Suture line with very narrow, parallel-sided external lobe and very low or low median saddle; ventrolateral saddle broadly rounded and almost symmetric; adventive lobe V-shaped, usually asymmetric.

Table 103. Conch ontogeny (Figs 72A, D-F) of Mouydiria mouydirensis n. sp.

\begin{tabular}{|c|c|c|c|}
\hline $\mathrm{dm}$ & conch shape & whorl cross section shape & aperture \\
\hline $2 \mathrm{~mm}$ & $\begin{array}{l}\text { thickly pachyconic; subinvolute } \\
\text { (ww/dm } \sim 0.80 ; \text { uw/dm } \sim 0.25 \text { ) }\end{array}$ & $\begin{array}{l}\text { moderately depressed; strongly embracing } \\
\text { (ww/wh } \sim 1.80 \text {; IZR } \sim 0.40 \text { ) }\end{array}$ & $\begin{array}{l}\text { moderate } \\
(\text { WER } \sim 1.85)\end{array}$ \\
\hline $8 \mathrm{~mm}$ & $\begin{array}{l}\text { thickly pachyconic; subinvolute } \\
\text { (ww/dm } \sim 0.75 ; \text { uw/dm } \sim 0.25 \text { ) }\end{array}$ & $\begin{array}{l}\text { moderately depressed; strongly embracing } \\
\text { (ww/wh } \sim 1.80 ; \text { IZR } \sim 0.40)\end{array}$ & $\begin{array}{l}\text { moderate } \\
(\text { WER } \sim 1.80)\end{array}$ \\
\hline $20 \mathrm{~mm}$ & $\begin{array}{l}\text { thinly pachyconic; subevolute } \\
(\mathrm{ww} / \mathrm{dm}=0.60-0.70 ; \text { uw/dm }=0.30-0.40)\end{array}$ & $\begin{array}{l}\text { moderately to strongly depressed; strongly } \\
\text { embracing ( } w w / w h=1.50-2.15 ; \mathrm{IZR}=0.30-0.40)\end{array}$ & $\begin{array}{l}\text { low } \\
(\text { WER }=1.60-1.75)\end{array}$ \\
\hline $30 \mathrm{~mm}$ & $\begin{array}{l}\text { thickly discoidal; subevolute } \\
(\mathrm{ww} / \mathrm{dm}=0.55-0.60 ; \text { uw/dm }=0.35-0.45)\end{array}$ & $\begin{array}{l}\text { moderately depressed; strongly embracing } \\
(w w / w h=1.50-2.00 ; \text { IZR }=0.30-0.40)\end{array}$ & $\begin{array}{l}\text { low to moderate } \\
(\text { WER }=1.60-1.80)\end{array}$ \\
\hline
\end{tabular}

Table 104. Conch dimensions (in $\mathrm{mm}$ ) and proportions for reference specimens of Mouydiria mouydirensis $\mathrm{n}$. sp.

\begin{tabular}{lccccccccccc}
\hline & $\mathrm{dm}$ & ww & wh & uw & ah & ww/dm & ww/wh & uw/dm & WER & IZR \\
\hline holotype MB.C.18736.1 & 29.5 & 17.0 & 10.7 & 12.2 & 7.0 & 0.58 & 1.59 & 0.41 & 1.72 & 0.35 \\
paratype MB.C.18736.2 & 26.1 & 16.2 & 8.9 & 11.1 & 6.3 & 0.62 & 1.82 & 0.43 & 1.73 & 0.30 \\
paratype MB.C.18736.3 & 23.9 & 13.8 & 8.4 & 8.3 & 5.4 & 0.58 & 1.64 & 0.35 & 1.68 & 0.35 \\
paratype MB.C.18736.4 & 20.9 & 13.2 & 7.1 & 8.3 & 5.0 & 0.63 & 1.87 & 0.40 & 1.72 & 0.30 \\
\hline
\end{tabular}

Table 105. Suture line proportions (Figs 72B, C) for Mouydiria mouydirensis n. sp.

\begin{tabular}{llllllll}
\hline specimen & at dm & EL w/d & EL/VLS & EL/AL & MS h & VLS w/h & remarks \\
\hline holotype MB.C.18736.1 & $24.2 \mathrm{~mm}$ & 0.49 & 0.66 & 0.92 & 0.19 & 0.74 & A lobe asymmetric \\
paratype MB.C.18736.2 & c. $20.0 \mathrm{~mm}$ & 0.47 & 0.76 & 0.98 & 0.23 & 0.61 & A lobe lanceolate, symmetric \\
\hline
\end{tabular}

Discussion. Mouydiria mouydirensis differs from M. bouhamedensis in the more slender conch (at $14 \mathrm{~mm} \mathrm{dm}$ : $\mathrm{ww} / \mathrm{dm} \sim 0.70$ in M. mouydirensis and $\sim 0.80$ in M. bouhamedensis). 

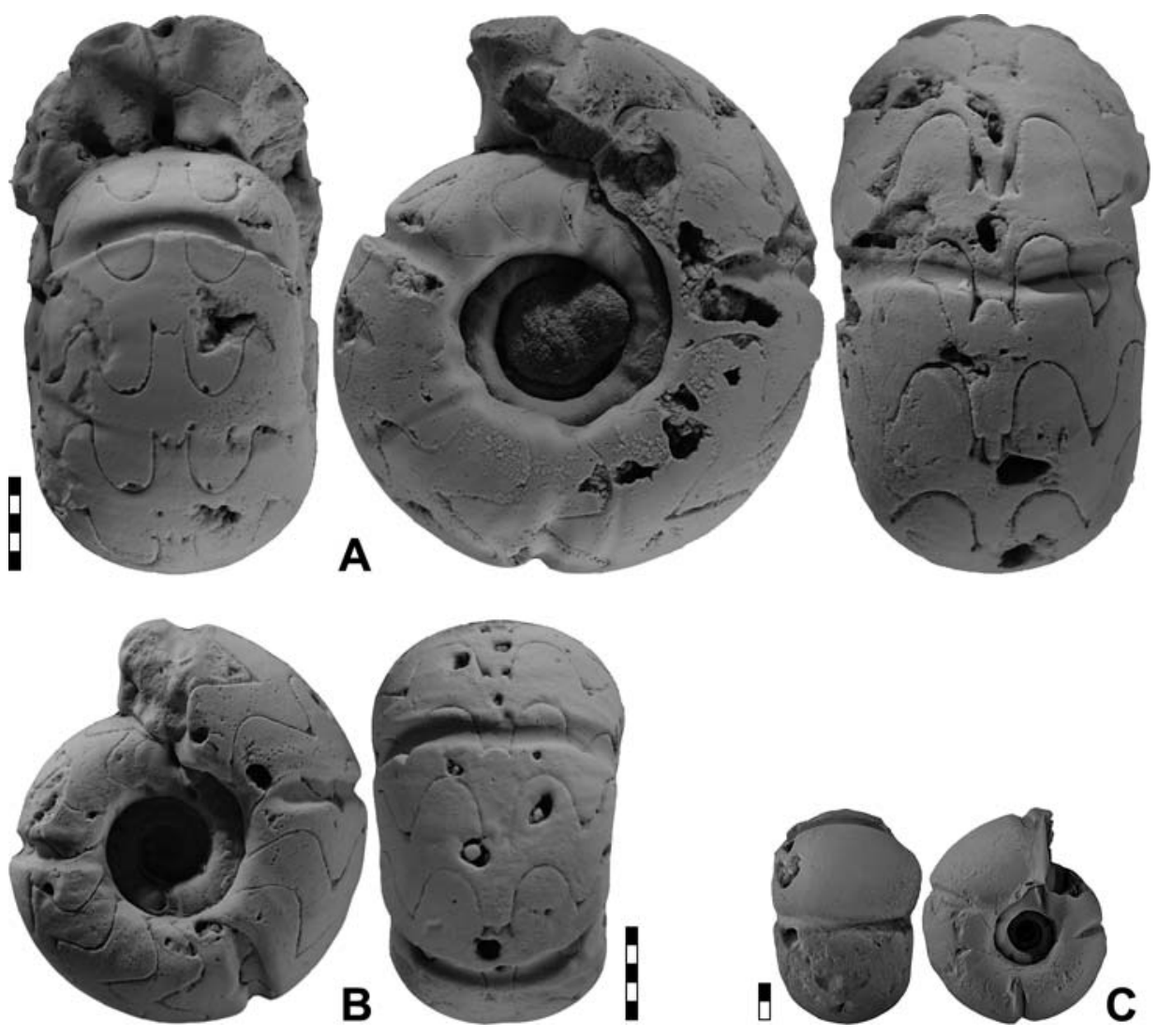

Figure 71. Mouydiria mouydirensis n. sp. from locality A320-5; all $\times 2$. A. Holotype MB.C.18736.1. B. Paratype MB.C.18736.4. C. Paratype MB.C. 18898.
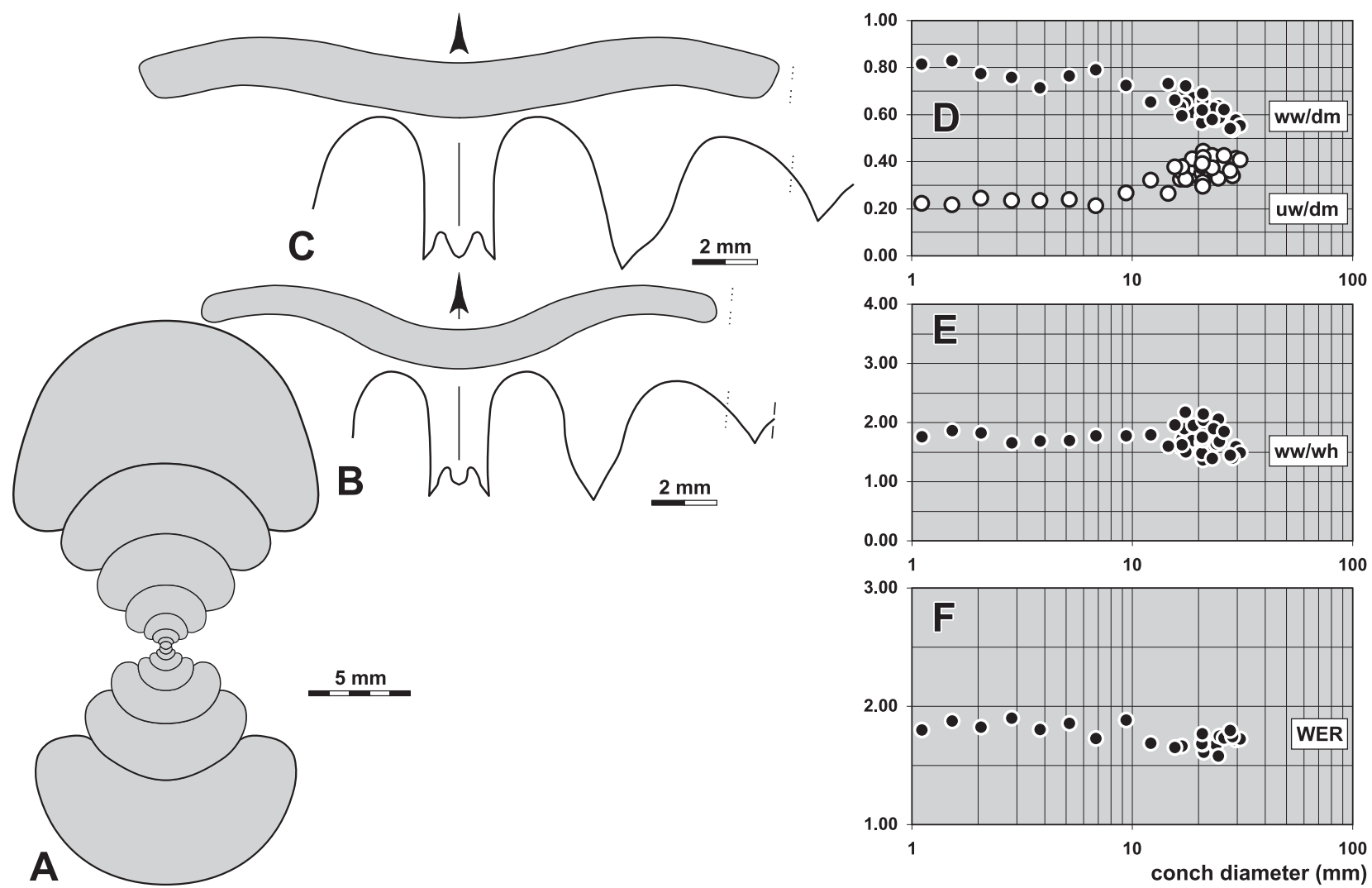

Figure 72. Mouydiria mouydirensis $n$. sp. A. Cross section of paratype MB.C.19013.1 from locality MOU-F; $\times 2.5$. B. Suture line and constriction of paratype MB.C.18736.2 from locality A320-5, at $21.1 \mathrm{~mm} \mathrm{dm}, 13.7 \mathrm{~mm} w w, 6.6 \mathrm{~mm}$ wh; $\times 4.0$. C. Suture line and constriction of holotype MB.C.18736.1 from locality A320-5, at $27.8 \mathrm{~mm} \mathrm{dm}, 16.3 \mathrm{~mm} w w, 9.1 \mathrm{~mm}$ wh; $\times 4.0$. D-F. Ontogenetic development of the conch width index (ww/dm), umbilical width index (uw/dm), whorl width index (ww/wh), and whorl expansion rate (WER) of all available specimens. 


\section{Mouydiria scutula n. sp.}

Figures 73, 74

Derivation of name. From Latin scutula $=$ roll, because of the conch shape.

Holotype. Specimen MB.C.18899, illustrated in Figure 73.

Type locality and horizon. Oued Temertasset, locality and sample MOU-D2 (Mouydir, South Algeria); Helicocyclus-Ouaoufilalites Assemblage. Material. Two specimens, conch diameter up to $25 \mathrm{~mm}$.

Diagnosis. Mouydiria with a thickly pachyconic conch up to $20 \mathrm{~mm}$ in $\mathrm{dm}$, thereafter becoming thinly pachyconic; conch subinvolute in the early juvenile stage and subevolute above $3 \mathrm{~mm} \mathrm{dm}$; umbilical margin subangular, umbilical wall steep, flattened; aperture low throughout ontogeny. Steinkern with wide and deep, convex constrictions with very shallow and wide ventral sinus; without ribs or nodes. Suture line with very narrow parallel-sided external lobe with slightly incurved flanks and very low median saddle; ventrolateral saddle broadly rounded and slightly asymmetric; adventive lobe deep and V-shaped, symmetric.
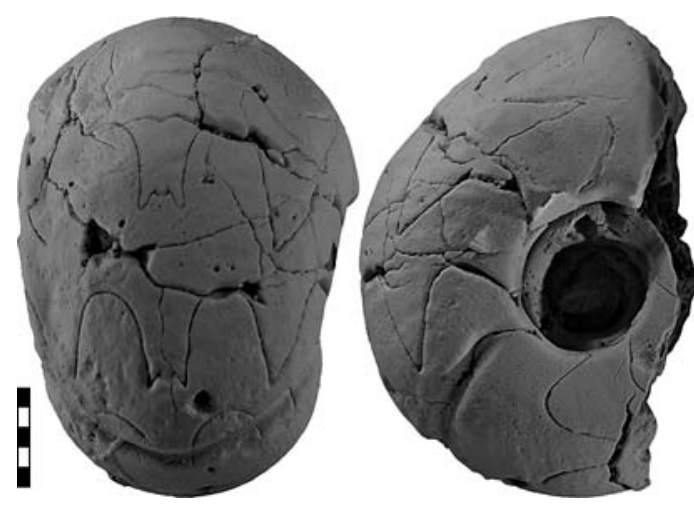

Figure 73. Mouydiria scutula n. sp., holotype MB.C.18899 from locality MOU-D2; $\times 2$.
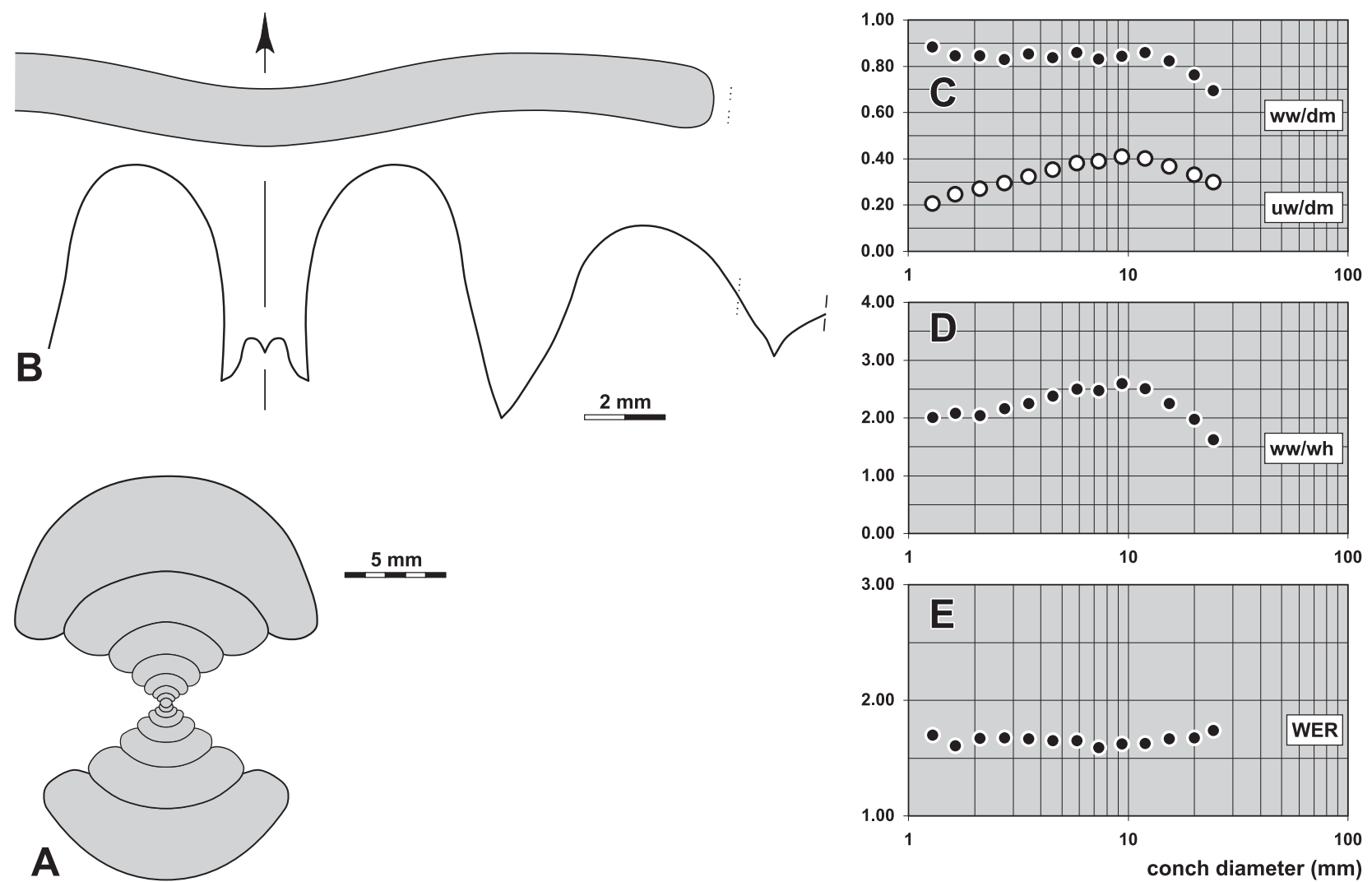

Figure 74. Mouydiria scutula n. sp. A. Cross section of paratype MB.C.18796 from locality MOU-B0; $\times 2.5$. B. Suture line and constriction of holotype MB.C.18899 from locality MOU-D2, at $18.9 \mathrm{~mm} \mathrm{dm}, 15.6 \mathrm{~mm} w w, 8.5 \mathrm{~mm}$ wh; $\times 5.0$. C-E. Ontogenetic development of the conch width index (ww/dm), umbilical width index (uw/dm), whorl width index (ww/wh), and whorl expansion rate (WER) of all available specimens. 
Table 106. Conch ontogeny (Figs 74A, C-E) of Mouydiria scutula $\mathrm{n}$. sp.

\begin{tabular}{|c|c|c|c|}
\hline $\mathrm{dm}$ & conch shape & whorl cross section shape & aperture \\
\hline $2 \mathrm{~mm}$ & $\begin{array}{l}\text { thickly pachyconic; subinvolute } \\
\text { (ww/dm } \sim 0.84 ; \text { uw/dm } \sim 0.26 \text { ) }\end{array}$ & $\begin{array}{l}\text { strongly depressed; very strongly embracing } \\
\text { (ww/wh } \sim 2.05 ; \text { IZR } \sim 0.46 \text { ) }\end{array}$ & $\begin{array}{l}\text { low } \\
(\text { WER } \sim 1.67)\end{array}$ \\
\hline $8 \mathrm{~mm}$ & $\begin{array}{l}\text { thickly pachyconic; subevolute } \\
\text { (ww/dm } \sim 0.84 ; \text { uw/dm } \sim 0.40 \text { ) }\end{array}$ & $\begin{array}{l}\text { very strongly depressed; strongly embracing } \\
\text { (ww/wh } \sim 2.60 ; \text { IZR } \sim 0.35 \text { ) }\end{array}$ & $\begin{array}{l}\text { low } \\
(\text { WER } \sim 1.62)\end{array}$ \\
\hline $20 \mathrm{~mm}$ & $\begin{array}{l}\text { thickly pachyconic; subevolute } \\
\text { (ww/dm } \sim 0.76 ; \text { uw/dm } \sim 0.33 \text { ) }\end{array}$ & $\begin{array}{l}\text { moderately depressed; strongly embracing } \\
\text { (ww/wh }=1.98 ; \text { IZR } \sim 0.41 \text { ) }\end{array}$ & $\begin{array}{l}\text { low } \\
(\text { WER }=1.68)\end{array}$ \\
\hline
\end{tabular}

Table 107. Conch dimensions (in $\mathrm{mm}$ ) and proportions for reference specimens of Mouydiria scutula $\mathrm{n}$. sp.

\begin{tabular}{llllllllllll}
\hline & $\mathrm{dm}$ & ww & wh & uw & ah & ww/dm & ww/wh & uw/dm & WER & IZR & \\
\hline holotype MB.C.18899 & 24.4 & 16.9 & 10.4 & 7.3 & 5.9 & 0.69 & 1.63 & 0.30 & 1.74 & 0.44 \\
paratype MB.C.18796 & 20.0 & 15.2 & 7.7 & 6.6 & 4.5 & 0.76 & 1.98 & 0.33 & 1.68 & 0.41 \\
\hline
\end{tabular}

Table 108. Suture line proportions (Fig. 74B) for Mouydiria scutula n. sp.

\begin{tabular}{llllllll}
\hline specimen & at dm & EL w/d & EL/NLS & EL/AL & MS h & VLS w/h & remarks \\
\hline holotype MB.C.18899 & $24.2 \mathrm{~mm}$ & 0.41 & 0.58 & 0.84 & 0.20 & 0.71 & A lobe deeper than E lobe \\
\hline
\end{tabular}

Discussion. Mouydiria scutula resembles M. bouhamedensis, but has a wider umbilicus (at $14 \mathrm{~mm} \mathrm{dm}$ : uw/dm $\sim 0.40$ in M. scutula and $\sim 0.30$ in M. bouhamedensis).

\section{Rotopericyclus Turner, 1948}

Type species. Pericyclus rotuliformis Crick, 1899 (OD).

Genus definition. Rotopericyclidae with rather large conch, reaching more than $120 \mathrm{~mm}$ in diameter. Conch subinvolute or subevolute, narrowing of the umbilicus in juvenile stages, some species with adult re-opening of the umbilicus. Shell and steinkern particularly in the juvenile and preadult stage with prominent concavo-convex or biconvex constrictions, direction rursiradiate; some species with rather prominent ribbing. Suture line with V-shaped or parallel-sided, very narrow external lobe $(\mathrm{EL} w / \mathrm{d}=0.30-0.45 ; \mathrm{EL} / \mathrm{AL}=0.80-0.95)$ and very low or low median saddle (MS $\mathrm{h}=0.15-0.30$ ); ventrolateral saddle broadly rounded, symmetric or slightly asymmetric; adventive lobe V-shaped, almost asymmetric.

Included species.

bailyi: Pericyclus Bailyi Crick, 1899, p. 438; Ireland.

clanensis: Pericyclus clanensis Crick, 1899, p. 437; Ireland.

foordi: Pericyclus Foordi Crick, 1899, p. 430; Ireland.

kaufmanni: Rotopericyclus kaufmanni n. sp.; Mouydir, Algeria.

leesoni: Pericyclus Leesoni Crick, 1899, p. 451; Ireland.

lubesederi: Rotopericyclus lubesederi n. sp.; Mouydir, Algeria.

rathi: Rotopericyclus rathi n. sp.; Mouydir, Algeria.

rotuliformis: Pericyclus rotuliformis Crick, 1899, p. 434; Ireland.

subplicatilis: Pericyclus subplicatilis Crick, 1899, p. 442; Ireland.

trapezoidalis: Pericyclus trapezoidalis Crick, 1899, p. 432; Ireland.

wendti: Rotopericyclus wendti n. sp.; Mouydir, Algeria.

? pinyonensis: Pericyclus (Rotopericyclus) pinyonensis Gordon, 1986: 30. Nevada.

? postremus: Rotopericyclus postremus Riley, 1996, p. 81; Lancashire.

Separation of the new species. The four species of Rotopericyclus from Oued Temertasset can be separated by their conch morphology and suture line. In the conch shape and its ontogenetic development, they are characterised as follows:

- R. kaufmanni - ww/dm increasing from $\sim 0.75$ at $2 \mathrm{~mm} \mathrm{dm}$ to $\sim 0.90$ at $20 \mathrm{~mm}$, thereafter decreasing to $\sim 0.50$ at $90 \mathrm{~mm} \mathrm{dm;} \mathrm{uw/dm}$ $\sim 0.30$ throughout ontogeny with little variation; umbilical margin angular;

- $R$. rathi - ww/dm rather stable between 0.65 and 0.75 up to $45 \mathrm{~mm} \mathrm{dm}$, thereafter a rapid decrease to $\sim 0.57$ at $70 \mathrm{~mm} \mathrm{dm}$; uw $/ \mathrm{dm}$ decreasing from $\sim 0.20$ at $2 \mathrm{~mm} \mathrm{dm}$ to $\sim 0.10$ at $7 \mathrm{~mm} \mathrm{dm}$, thereafter increasing to $\sim 0.35$ at $50 \mathrm{~mm} \mathrm{dm}$; umbilical margin subangular;

- R. wendti - ww/dm increasing from $\sim 0.70$ at $2 \mathrm{~mm} \mathrm{dm}$ to $0.75-0.85$ at $10 \mathrm{~mm}$, thereafter decreasing to $\sim 0.40$ at $90 \mathrm{~mm} \mathrm{dm}$; uw/dm $\sim 0.20$ up to $5 \mathrm{~mm} \mathrm{dm}$, thereafter $0.25-0.33$ with little variation; umbilical margin rounded;

- . lubesederi - ww/dm rather stable at $\sim 0.75$ up to $10 \mathrm{~mm} \mathrm{dm}$, thereafter a continuous decrease to $\sim 0.40$ at $90 \mathrm{~mm} \mathrm{dm}$; uw $/ \mathrm{dm} \sim 0.12 \mathrm{up}$ to $6 \mathrm{~mm} \mathrm{dm}$, thereafter $\sim 0.20$ with little variation; umbilical margin rounded. 
The steinkern surface differs in the four species:

- R. kaufmanni - numerous gently biconvex constrictions;

- R. rathi - numerous concavo-convex constrictions;

- $R$. wendti - numerous biconvex constrictions;

- R. lubesederi - adult stage without constrictions.

The suture line offers more distinguishing characters (in specimens larger than $24 \mathrm{~mm} \mathrm{dm}$ ):

- R. kaufmanni - external lobe V-shaped with gently sinuous flanks, median saddle very low, adventive lobe moderately wide;

- . rathi - external lobe parallel-sided with slightly incurved flanks, median saddle low, adventive lobe narrow;

- $R$. wendti - external lobe parallel-sided with slightly sinuous flanks, median saddle low, adventive lobe very narrow;

- R. lubesederi - external lobe parallel-sided, median saddle very low, adventive lobe moderately wide.

Discussion. A revision of the Irish species is necessary to define the limits of the genus and to separate the species. The Algerian material demonstrates that the variability of conch ontogeny is rather wide among the species and that it is difficult to find clear apomorphic characters. Most of the species show a temporary increase of the uw/dm ratio during ontogeny, and many possess tendencies to increase the ww/dm ratio in an intermediate phase or in the adult stage.

The Algerian species appear to be very heterogeneous with respect to their conch morphology and suture line. However, they share some characters such as the rather complex conch ontogeny. While R. lubesederi is still rather close to species of the genus Muensteroceras (such as M. multitudum), species such as $R$. kaufmanni and R. rathi show a derived morphology with a rather widely umbilicate conch.

\section{Rotopericyclus kaufmanni n. sp.}

Figures 75, 76

Derivation of name. After Bernd Kaufmann, who collected some of the material.

Holotype. Specimen MB.C.18806.1, illustrated in Figure 75A.

Type locality and horizon. Oued Temertasset, locality and sample MOU-C2 (Mouydir, South Algeria); Helicocyclus-Ouaoufilalites Assemblage. Material. 17 specimens, conch diameter up to $90 \mathrm{~mm}$.

Diagnosis. Rotopericyclus with thickly pachyconic conch in the early juvenile stage, conch thinly globular between 7 and 20 mm dm, and becoming thickly discoidal at $60 \mathrm{~mm} \mathrm{dm}$; conch subinvolute or subevolute throughout ontogeny with minor changes; umbilical margin in the adult stage angular, umbilical wall flattened and oblique; aperture low throughout ontogeny. Ornament with coarse growth lines, course slightly biconvex with very low lateral sinus and shallow ventral sinus, direction slightly rursiradiate; deep shell and steinkern constrictions parallel to the growth lines. Suture line with very narrow and V-shaped external lobe, median saddle very low; ventrolateral saddle broadly rounded and almost symmetric; adventive lobe V-shaped, symmetric.

Table 109. Conch ontogeny (Figs 76A-C, E-G) of Rotopericyclus kaufmanni n. sp.

\begin{tabular}{|c|c|c|c|}
\hline$d m$ & conch shape & whorl cross section shape & aperture \\
\hline $4 \mathrm{~mm}$ & $\begin{array}{l}\text { thickly pachyconic; subinvolute or subevolute } \\
\text { (ww/dm } \sim 0.82 ; \mathrm{uw} / \mathrm{dm}=0.28-0.32 \text { ) }\end{array}$ & $\begin{array}{l}\text { strongly depressed; very strongly embracing } \\
\text { (ww/wh }=2.00-2.20 ; \text { IZR }=0.45-0.50 \text { ) }\end{array}$ & $\begin{array}{l}\text { low } \\
(\text { WER } \sim 1.60)\end{array}$ \\
\hline $10 \mathrm{~mm}$ & $\begin{array}{l}\text { thinly globular; subinvolute } \\
\text { (ww/dm } \sim 0.90 ; \mathrm{uw} / \mathrm{dm} \sim 0.30 \text { ) }\end{array}$ & $\begin{array}{l}\text { strongly depressed; very strongly embracing } \\
\text { (ww/wh }=2.25-2.40 ; \text { IZR } \sim 0.48 \text { ) }\end{array}$ & $\begin{array}{l}\text { low } \\
(\text { WER } \sim 1.55)\end{array}$ \\
\hline $30 \mathrm{~mm}$ & $\begin{array}{l}\text { thickly pachyconic to thinly globular; subinvolute } \\
(\mathrm{ww} / \mathrm{dm}=0.75-0.90 ; \mathrm{uw} / \mathrm{dm}=0.27-0.30 \text { ) }\end{array}$ & $\begin{array}{l}\text { strongly depressed; very strongly embracing } \\
\text { (ww/wh }=2.00-2.15 ; \text { IZR } \sim 0.45 \text { ) }\end{array}$ & $\begin{array}{l}\text { low } \\
\text { (WER } \sim 1.65)\end{array}$ \\
\hline $60 \mathrm{~mm}$ & $\begin{array}{l}\text { thickly discoidal; subinvolute or subevolute } \\
\text { (ww/dm }=0.55-0.60 ; u w / d m=0.28-0.34 \text { ) }\end{array}$ & $\begin{array}{l}\text { moderately depressed; very strongly embracing } \\
(\mathrm{ww} / \mathrm{wh}=1.50-1.60 ; \mathrm{IZR}=0.45-0.48)\end{array}$ & $\begin{array}{l}\text { low } \\
\text { (WER 1.60) }\end{array}$ \\
\hline 90 mm & $\begin{array}{l}\text { discoidal; subevolute } \\
\text { (ww/dm } \sim 0.49 ; \text { uw/dm } \sim 0.31 \text { ) }\end{array}$ & $\begin{array}{l}\text { weakly depressed; very strongly embracing } \\
\text { (ww/wh }=1.25 ; \mathrm{IZR} \sim 0.45 \text { ) }\end{array}$ & $\begin{array}{l}\text { low } \\
(\text { WER } \sim 1.64)\end{array}$ \\
\hline
\end{tabular}

Table 110. Conch dimensions (in $\mathrm{mm}$ ) and proportions for reference specimens of Rotopericyclus kaufmanni n. sp.

\begin{tabular}{lllllllllll}
\hline & $\mathrm{dm}$ & ww & wh & uw & ah & ww/dm & ww/wh & uw/dm & WER & IZR \\
\hline holotype MB.C.18806.1 & 88.8 & 43.3 & 35.1 & 27.9 & 19.4 & 0.49 & 1.23 & 0.31 & 1.64 & 0.45 \\
paratype MB.C.18806.3 & 60.7 & 36.5 & 22.7 & 20.4 & 12.0 & 0.60 & 1.61 & 0.34 & 1.56 & 0.47 \\
paratype MB.C.18806.2 & 57.4 & 33.3 & 22.4 & 16.1 & 12.6 & 0.58 & 1.49 & 0.28 & 1.64 & 0.44 \\
paratype MB.C.18806.4 & 54.3 & 39.5 & 22.8 & 14.4 & 11.9 & 0.73 & 1.73 & 0.26 & 1.64 & 0.48 \\
\hline
\end{tabular}


Table 111. Suture line proportions (Fig. 76D) for Rotopericyclus kaufmanni $\mathrm{n}$. sp.

\begin{tabular}{llllllll}
\hline specimen & at dm & EL w/d & EL/VLS & EL/AL & MS h & VLS w/h & remarks \\
\hline paratype MB.C.18806.2 & c. $33.0 \mathrm{~mm}$ & 0.42 & 0.58 & 0.89 & 0.15 & 0.72 & flanks of E lobe gently sinuous \\
\hline
\end{tabular}

Discussion. Among the Irish species, it is Rotopericyclus rotuliformis that most closely resembles $R$. kaufmanni, particularly with regard to the prominent constrictions. However, $R$. rotuliformis has a more slender conch at comparable diameters (at $60 \mathrm{~mm} \mathrm{dm:} \mathrm{ww/dm} \sim 0.43$ in $R$. rotuliformis but 0.60 in $R$. kaufmanni). The other Irish species lack the strong constrictions.
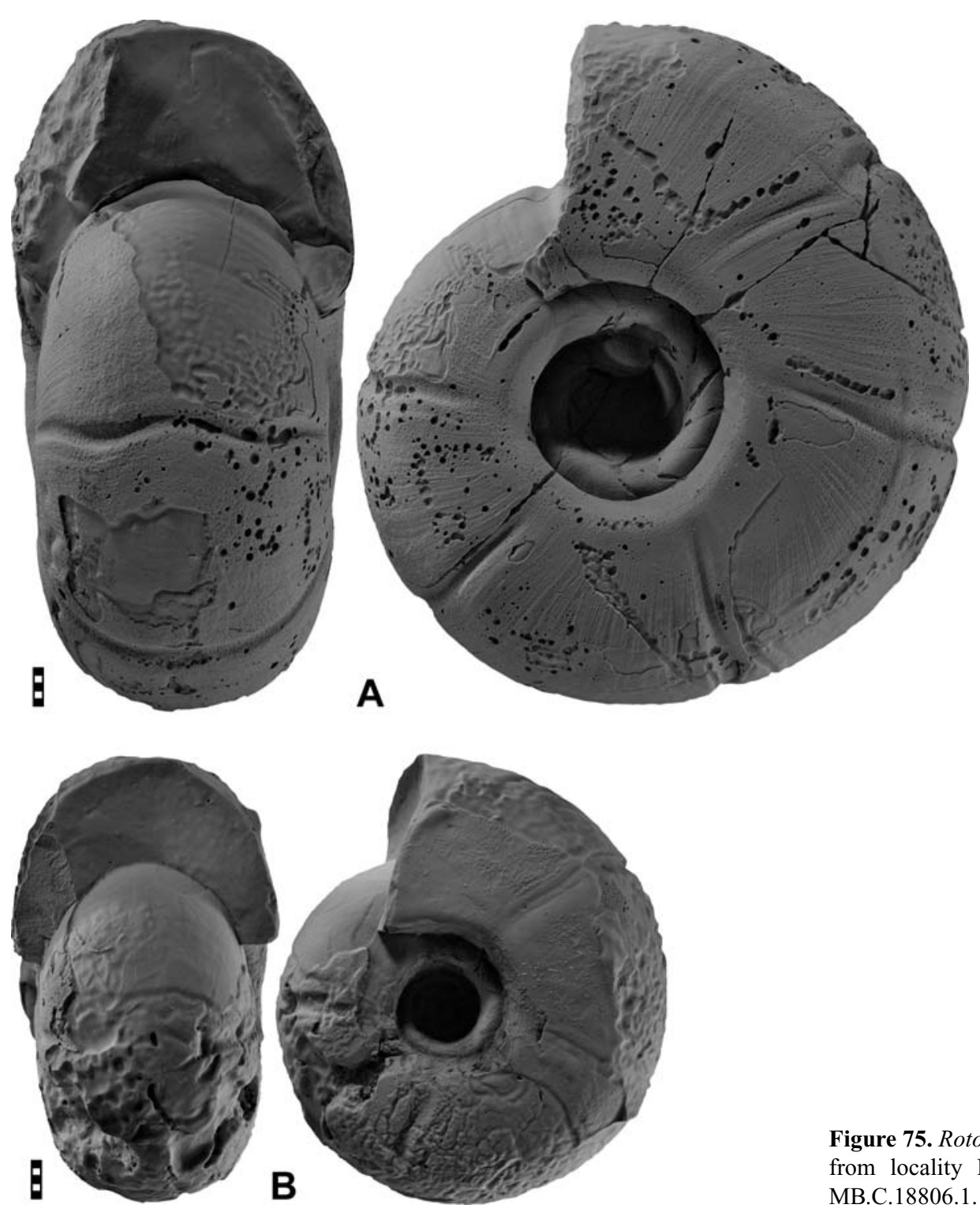

Figure 75. Rotopericyclus kaufmanni $\quad$ n. sp. from locality MOU-C1; all $\times 1$. A. Holotype MB.C.18806.1. B. Paratype MB.C.18806.2. 

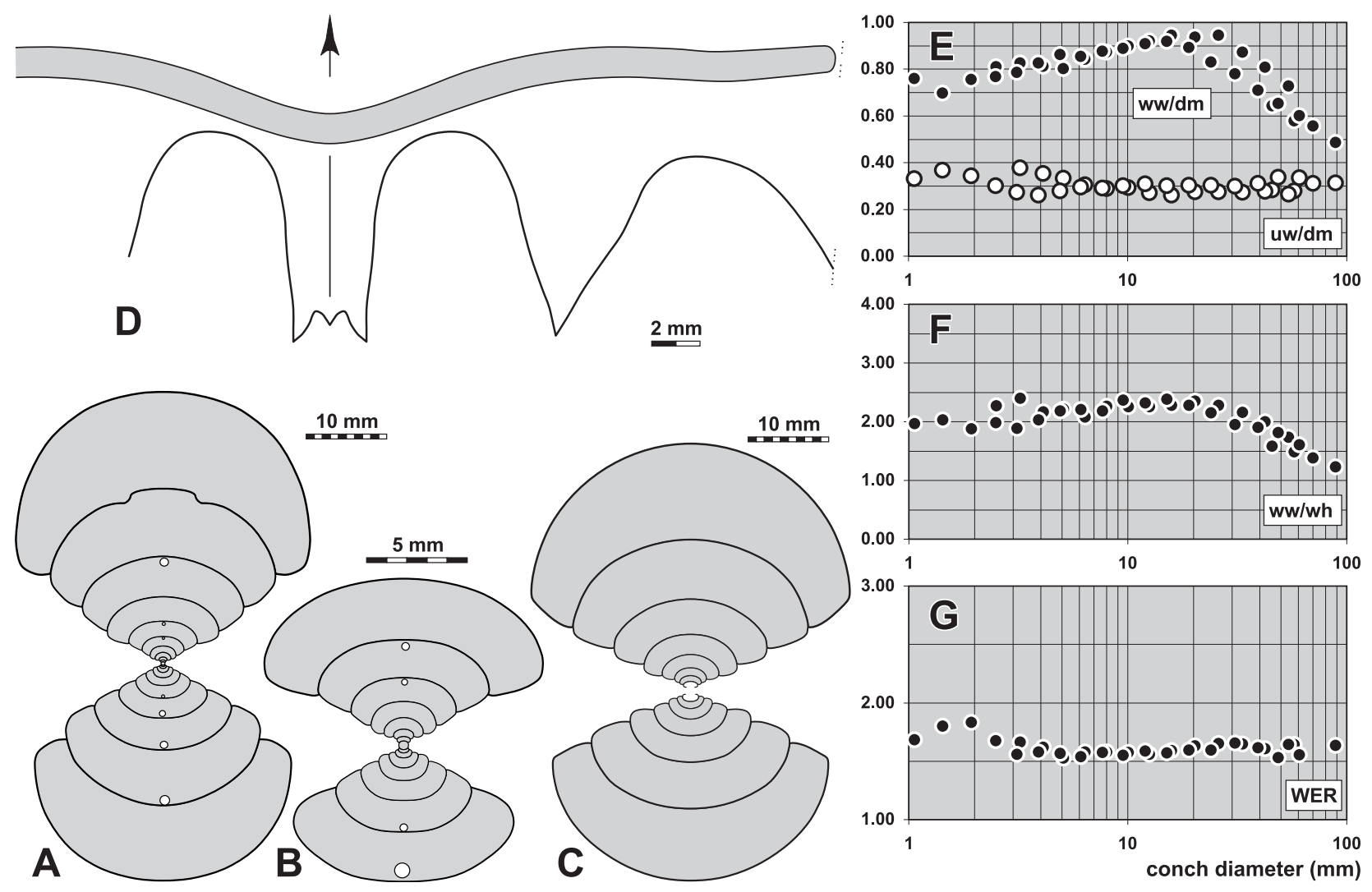

Figure 76. Rotopericyclus kaufmanni n. sp. from locality MOU-C1. A. Cross section of paratype MB.C.18806.3; $\times 1.0$. B. Cross section of the inner whorls or the same specimen; $\times 2.5$. C. Cross section of paratype MB.C.18806.4; $\times 1.0$. D. Suture line and constriction of paratype MB.C.18806.2, at $26.3 \mathrm{~mm}$ ww, $16.5 \mathrm{~mm}$ wh; $\times 3.0$. E-G. Ontogenetic development of the conch width index (ww/dm), umbilical width index (uw/dm), whorl width index (ww/wh), and whorl expansion rate (WER) of all available specimens.

\section{Rotopericyclus rathi n. sp.}

Figures 77,78

Derivation of name. After Jochen Rath, who collected some of the material.

Holotype. Specimen MB.C.18807.1, illustrated in Figure 77A.

Type locality and horizon. Oued Temertasset, locality and sample MOU-C2 (Mouydir, South Algeria); Helicocyclus-Ouaoufilalites Assemblage. Material. 13 specimens, conch diameter up to $70 \mathrm{~mm}$.

Diagnosis. Rotopericyclus with thickly pachyconic conch up to $45 \mathrm{~mm}$ in $\mathrm{dm}$, thereafter a continuous transformation into a thickly discoidal conch of about $70 \mathrm{~mm}$ in $\mathrm{dm}$; conch involute or subinvolute in the juvenile and intermediate stage and subevolute in the adult stage; umbilical margin in the adult stage subangular, umbilical wall flattened and steep; aperture moderately high in juveniles and low above $25 \mathrm{~mm} \mathrm{dm}$. Ornament with coarse growth lines, course concavo-convex with very low lateral sinus and moderately deep ventral sinus, direction slightly rursiradiate in the adult stage; deep shell and steinkern constrictions parallel to the growth lines. Suture line with very narrow parallel-sided external lobe, median saddle low; ventrolateral saddle broadly rounded and almost symmetric; adventive lobe V-shaped, narrow and symmetric.

Table 112. Conch ontogeny (Figs 78A, B, D-F) of Rotopericyclus rathi $\mathrm{n} . \mathrm{sp}$.

\begin{tabular}{|c|c|c|c|}
\hline $\mathrm{dm}$ & conch shape & whorl cross section shape & aperture \\
\hline $4 \mathrm{~mm}$ & $\begin{array}{l}\text { thickly pachyconic; involute } \\
\text { (ww/dm } \sim 0.75 ; \mathrm{uw} / \mathrm{dm} \sim 0.13 \text { ) }\end{array}$ & $\begin{array}{l}\text { weakly depressed; very strongly embracing } \\
\text { (ww/wh } \sim 1.45 ; \text { IZR } \sim 0.45 \text { ) }\end{array}$ & $\begin{array}{l}\text { moderate } \\
\text { (WER } \sim 1.90)\end{array}$ \\
\hline $10 \mathrm{~mm}$ & $\begin{array}{l}\text { thinly pachyconic; involute } \\
\text { (ww/dm } \sim 0.68 ; \text { uw/dm } \sim 0.14 \text { ) }\end{array}$ & $\begin{array}{l}\text { weakly depressed; strongly embracing } \\
\text { (ww/wh } \sim 1.38 ; \text { IZR } \sim 0.42 \text { ) }\end{array}$ & $\begin{array}{l}\text { moderate } \\
\text { (WER } \sim 1.95)\end{array}$ \\
\hline $30 \mathrm{~mm}$ & $\begin{array}{l}\text { thickly pachyconic; subinvolute } \\
\text { (ww/dm } \sim 0.75 ; \text { uw/dm } \sim 0.27 \text { ) }\end{array}$ & $\begin{array}{l}\text { moderately depressed; very strongly embracing } \\
\text { (ww/wh } \sim 1.80 \text {; IZR } \sim 0.48 \text { ) }\end{array}$ & $\begin{array}{l}\text { low } \\
\text { (WER } \sim 1.60)\end{array}$ \\
\hline $60 \mathrm{~mm}$ & $\begin{array}{l}\text { thinly pachyconic; subevolute } \\
\text { (ww/dm } \sim 0.65 ; \mathrm{uw} / \mathrm{dm} \sim 0.35 \text { ) }\end{array}$ & $\begin{array}{l}\text { moderately depressed; strongly embracing } \\
\text { (ww/wh } \sim 1.75 ; \text { IZR } \sim 0.40)\end{array}$ & $\begin{array}{l}\text { low } \\
\text { (WER 1.65) }\end{array}$ \\
\hline
\end{tabular}


Table 113. Conch dimensions (in $\mathrm{mm}$ ) and proportions for reference specimens of Rotopericyclus rathi $\mathrm{n}$. sp.

\begin{tabular}{lccccccccccc}
\hline & $\mathrm{dm}$ & ww & wh & uw & ah & ww/dm & ww/wh & uw/dm & WER & IZR \\
\hline holotype MB.C.18807.1 & 70.0 & 39.8 & 26.6 & 23.8 & 14.9 & 0.57 & 1.50 & 0.34 & 1.61 & 0.44 \\
paratype MB.C.18807.3 & 58.9 & 38.4 & 21.9 & 20.3 & 13.6 & 0.65 & 1.75 & 0.35 & 1.69 & 0.38 \\
paratype MB.C.18807.2 & 30.2 & 22.3 & 13.0 & 7.5 & 6.4 & 0.74 & 1.71 & 0.25 & 1.61 & 0.51 \\
\hline
\end{tabular}
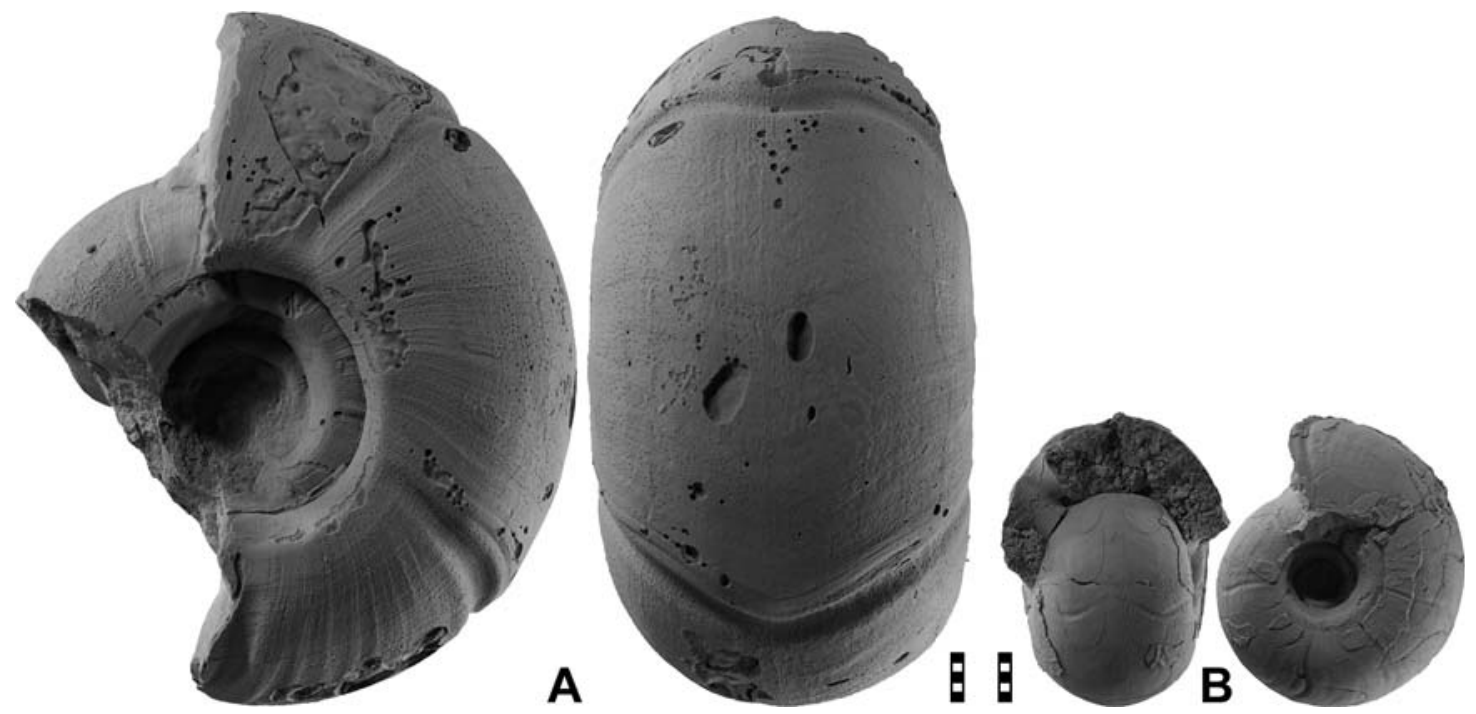

Figure 77. Rotopericyclus rathi n. sp. from locality MOU-C1; all ×1. A. Holotype MB.C.18807.1. B. Paratype MB.C.18807.2.
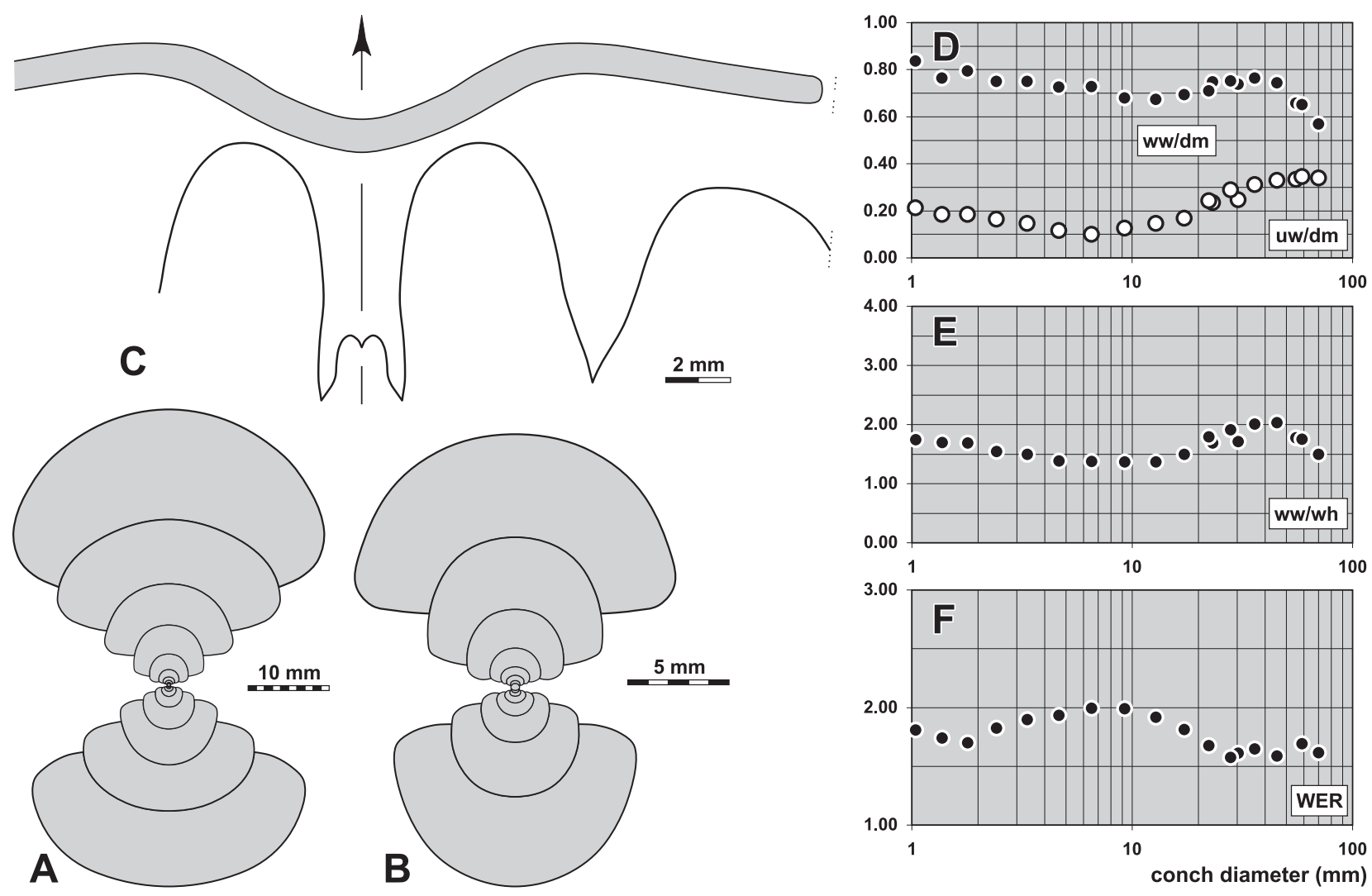

Figure 78. Rotopericyclus rathi n. sp. from locality MOU-C1. A. Cross section of paratype MB.C.18807.3; $\times 1.0$. B. Cross section of the inner whorls or the same specimen; $\times 2.5$. C. Suture line and constriction of paratype MB.C.18807.2, at $16.4 \mathrm{~mm}$ ww, $8.4 \mathrm{~mm}$ wh; $\times 4.0$. D-F. Ontogenetic development of the conch width index (ww/dm), umbilical width index (uw/dm), whorl width index (ww/wh), and whorl expansion rate (WER) of all available specimens. 
Table 114. Suture line proportions (Fig. 78C) for Rotopericyclus rathi n. sp.

\begin{tabular}{lllllllll}
\hline specimen & at dm & EL w/d & EL/VLS & EL/AL & MS h & VLS w/h & remarks \\
\hline paratype MB.C.18807.2 & c. $24.0 \mathrm{~mm}$ & 0.31 & 0.51 & 0.91 & 0.25 & 0.62 & flanks of E lobe slightly concave \\
\hline
\end{tabular}

Discussion. Rotopericyclus rathi differs from R. rotuliformis in the much stouter conch.

\section{Rotopericyclus wendti n. sp.}

Figures 79, 80

Derivation of name. After Jobst Wendt (Tübingen), who led the first excursions during which the material was discovered.

Holotype. Specimen MB.C.18808.1, illustrated in Figure 79A.

Type locality and horizon. Oued Temertasset, locality and sample MOU-C2 (Mouydir, South Algeria); Helicocyclus-Ouaoufilalites Assemblage. Material. 129 specimens, conch diameter up to $92 \mathrm{~mm}$.

Diagnosis. Rotopericyclus with thickly pachyconic conch up to $15 \mathrm{~mm}$ in $\mathrm{dm}$, thereafter continuous transformation into a thinly discoidal conch of about $90 \mathrm{~mm}$ in $\mathrm{dm}$; conch usually subinvolute, but with wider umbilicus above $8 \mathrm{~mm} \mathrm{dm}$; umbilical margin rounded, umbilical wall convex; aperture low or moderately high throughout ontogeny. Ornament with coarse growth lines, course biconvex with low lateral sinus and deep ventral sinus, direction slightly rursiradiate in the adult stage; deep shell and steinkern constrictions parallel to the growth lines. Suture line with very narrow parallel-sided external lobe, median saddle very low; ventrolateral saddle broadly rounded and almost symmetric; adventive lobe $\mathrm{V}$-shaped, very narrow and symmetric.

Table 115. Conch ontogeny (Figs 80A-C, E-G) of Rotopericyclus wendti n. sp.

\begin{tabular}{|c|c|c|c|}
\hline$d m$ & conch shape & whorl cross section shape & aperture \\
\hline $4 \mathrm{~mm}$ & $\begin{array}{l}\text { thickly pachyconic; subinvolute } \\
(\mathrm{ww} / \mathrm{dm}=0.75-0.80 ; \mathrm{uw} / \mathrm{dm}=0.15-0.20)\end{array}$ & $\begin{array}{l}\text { moderately depressed; very strongly embracing } \\
\text { (ww/wh }=1.60-1.75 ; \text { IZR }=0.45-0.55 \text { ) }\end{array}$ & $\begin{array}{l}\text { low to moderate } \\
\text { (WER }=1.65-1.85)\end{array}$ \\
\hline $10 \mathrm{~mm}$ & $\begin{array}{l}\text { thickly pachyconic; subinvolute } \\
(\mathrm{ww} / \mathrm{dm}=0.75-0.85 ; \mathrm{ww} / \mathrm{dm}=0.20-0.30)\end{array}$ & $\begin{array}{l}\text { moderately to strongly depressed; very strongly } \\
\text { embracing ( } w w / w h=1.80-2.25 ; \mathrm{IZR}=0.45-0.50 \text { ) }\end{array}$ & $\begin{array}{l}\text { low } \\
(\text { WER }=1.50-1.75)\end{array}$ \\
\hline $30 \mathrm{~mm}$ & $\begin{array}{l}\text { thinly pachyconic; subinvolute } \\
(\mathrm{ww} / \mathrm{dm}=0.60-0.70 ; \mathrm{uw} / \mathrm{dm}=0.20-0.30)\end{array}$ & $\begin{array}{l}\text { weakly to moderately depressed; strongly embracing } \\
(\mathrm{ww} / \mathrm{wh}=1.20-1.60 ; \mathrm{IZR}=0.40-0.45)\end{array}$ & $\begin{array}{l}\text { low to moderate } \\
(\mathrm{WER}=1.70-1.90)\end{array}$ \\
\hline $60 \mathrm{~mm}$ & $\begin{array}{l}\text { thinly to thickly discoidal; subinvolute or } \\
\text { subevolute (ww/dm }=0.45-0.55 \text {; } \\
\text { uw/dm }=0.25-0.33 \text { ) }\end{array}$ & $\begin{array}{l}\text { weakly depressed; strongly embracing } \\
(\mathrm{ww} / \mathrm{wh}=1.00-1.30 ; \mathrm{IZR}=0.40-0.45)\end{array}$ & $\begin{array}{l}\text { low } \\
(\text { WER }=1.60-1.75)\end{array}$ \\
\hline $90 \mathrm{~mm}$ & $\begin{array}{l}\text { thinly discoidal; subinvolute or subevolute } \\
\text { (ww/dm } \sim 0.38 ; \text { uw/dm } \sim 0.30 \text { ) }\end{array}$ & $\begin{array}{l}\text { weakly depressed; strongly embracing } \\
\text { (ww/wh } \sim 1.00 ; \text { IZR }=0.40-0.45 \text { ) }\end{array}$ & $\begin{array}{l}\text { moderate } \\
(\text { WER } \sim 1.80)\end{array}$ \\
\hline
\end{tabular}

Table 116. Conch dimensions (in $\mathrm{mm}$ ) and proportions for reference specimens of Rotopericyclus wendti $\mathrm{n}$. sp.

\begin{tabular}{|c|c|c|c|c|c|c|c|c|c|c|}
\hline & $\mathrm{dm}$ & ww & wh & uw & ah & $w w / d m$ & ww/wh & $\mathrm{uw} / \mathrm{dm}$ & WER & IZR \\
\hline holotype MB.C.18808.1 & 86.2 & 33.2 & 33.8 & 23.0 & 20.4 & 0.39 & 0.98 & 0.27 & 1.72 & 0.40 \\
\hline paratype MB.C.18808.3 & 83.3 & 34.8 & 35.0 & 22.3 & 19.1 & 0.42 & 0.99 & 0.27 & 1.68 & 0.46 \\
\hline paratype MB.C.18808.4 & 66.6 & 30.9 & 27.2 & 17.5 & 14.9 & 0.46 & 1.13 & 0.26 & 1.66 & 0.45 \\
\hline paratype MB.C.18808.2 & 54.8 & 25.4 & 25.6 & 12.1 & 13.4 & 0.46 & 0.99 & 0.22 & 1.75 & 0.48 \\
\hline paratype MB.C.18808.5 & 41.9 & 21.8 & 18.6 & 8.2 & 11.1 & 0.52 & 1.17 & 0.19 & 1.85 & 0.40 \\
\hline
\end{tabular}

Table 117. Suture line proportions (Fig. 80D) for Rotopericyclus wendti n. sp.

\begin{tabular}{llllllll}
\hline specimen & at dm & EL w/d & EL/VLS & EL/AL & MS h & VLS w/h & remarks \\
\hline paratype MB.C.18808.5 & $40.7 \mathrm{~mm}$ & 0.32 & 0.53 & 0.87 & 0.19 & 0.61 & A lobe very deep and narrow \\
\hline
\end{tabular}

Discussion. The strong constrictions of Rotopericyclus wendti differentiate it from R. subplicatilis and R. foordi. 

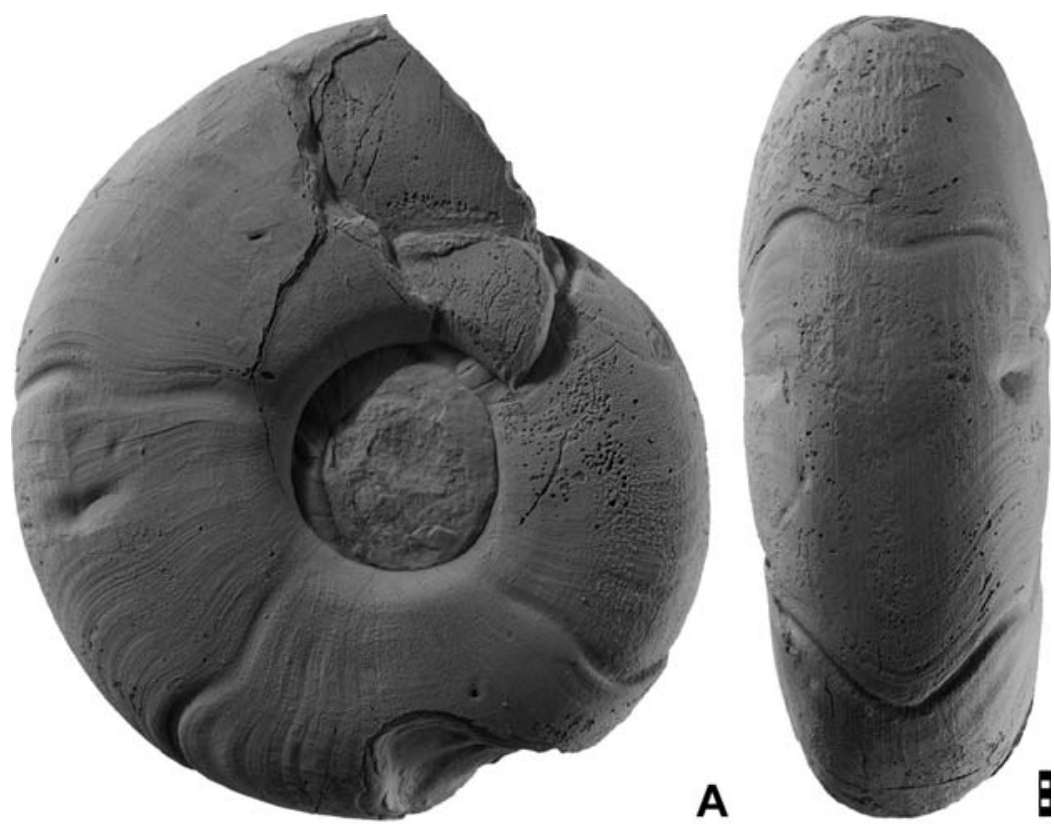

4 Figure 79. Rotopericyclus wendti n. sp. from locality MOU-C1; all $\times 1$. A. Holotype MB.C.18808.1. B. Paratype MB.C.18808.2.
Figure 80. Rotopericyclus wendti n. sp. from locality MOU-C1. A. Cross section of paratype MB.C. $18808.3 ; \times 1.0$. B. Cross section of the inner whorls or the same specimen; $\times 2.5$. C. Cross section of paratype MB.C.18808.4; $\times 1.0$. D. Suture line and constriction of paratype MB.C.18808.5, at $40.7 \mathrm{~mm}$ $\mathrm{dm}, 22.0 \mathrm{~mm}$ ww, $20.2 \mathrm{~mm}$ wh; $\times 2.5$. E-G. Ontogenetic development of the conch width index (ww/dm), umbilical width index (uw/dm), whorl width index (ww/wh), and whorl expansion rate (WER) of all available specimens.

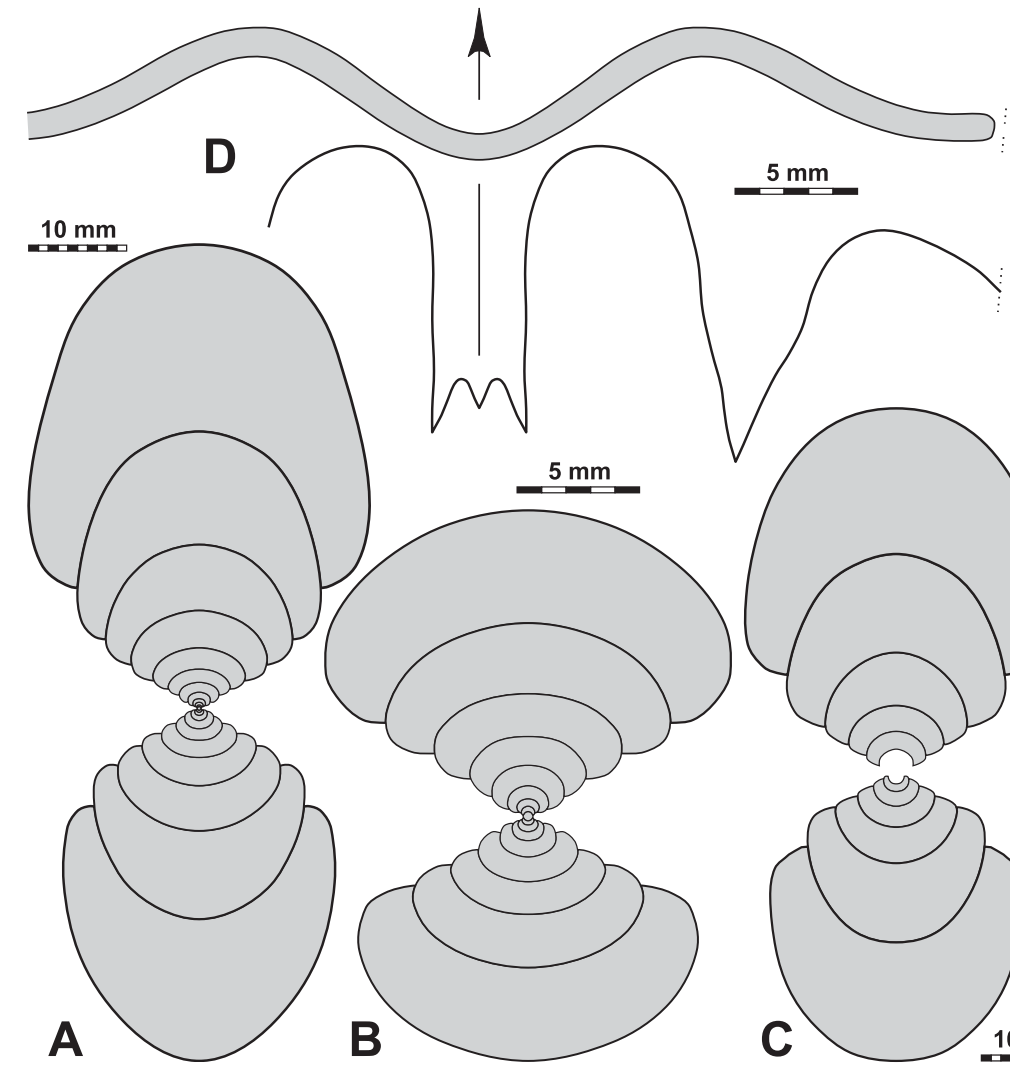

B
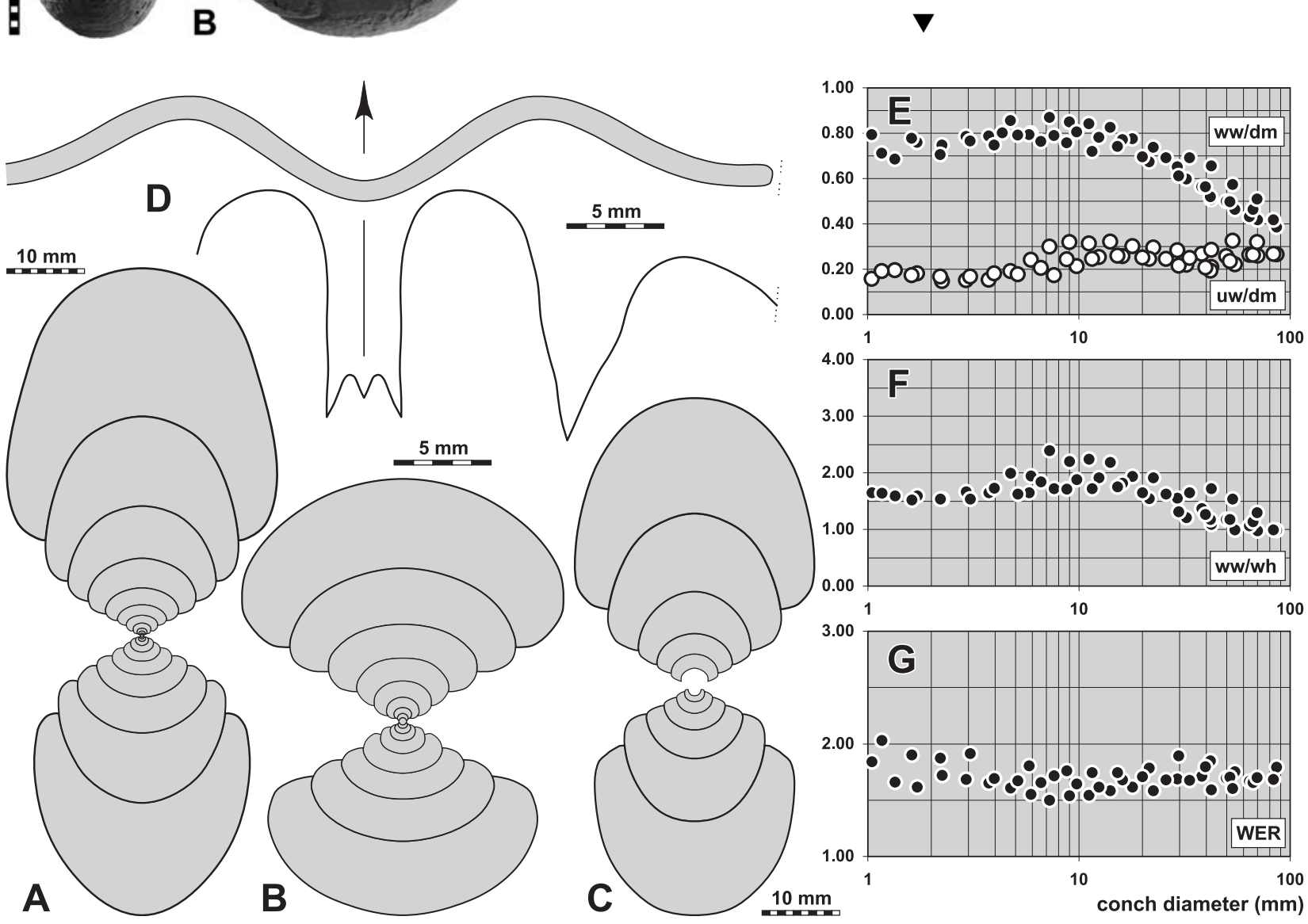


\section{Rotopericyclus lubesederi n. sp.}

Figures 81, 82

Derivation of name. After Stefan Lubeseder, who collected some of the material.

Holotype. Specimen MB.C.18809.1, illustrated in Figure 81A.

Type locality and horizon. Oued Temertasset, locality and sample MOU-C2 (Mouydir, South Algeria); Helicocyclus-Ouaoufilalites Assemblage. Material. 47 specimens, conch diameter up to $90 \mathrm{~mm}$.

Diagnosis. Rotopericyclus with thickly pachyconic conch up to $10 \mathrm{~mm}$ in $\mathrm{dm}$, thereafter continuous transformation into a thinly discoidal conch above $60 \mathrm{~mm} \mathrm{dm}$; conch involute up to $6 \mathrm{~mm} \mathrm{dm}$ and thereafter subinvolute; umbilical margin rounded, umbilical wall convex; aperture moderately high throughout ontogeny. Ornament with coarse growth lines, course biconvex with low lateral sinus and deep ventral sinus, direction slightly rursiradiate in the adult stage; adult stage without shell or steinkern constrictions. Suture line with very narrow subparallel-sided external lobe, median saddle low; ventrolateral saddle broadly rounded and slightly asymmetric; adventive lobe V-shaped, symmetric.

Table 118. Conch ontogeny (Figs $82 \mathrm{~A}-\mathrm{C}, \mathrm{E}-\mathrm{G})$ of Rotopericyclus lubesederi $\mathrm{n}$. sp.

\begin{tabular}{|c|c|c|c|}
\hline $\mathrm{dm}$ & conch shape & whorl cross section shape & aperture \\
\hline $4 \mathrm{~mm}$ & $\begin{array}{l}\text { thickly pachyconic; involute } \\
\text { (ww/dm } \sim 0.80 ; \mathrm{uw} / \mathrm{dm} \sim 0.12 \text { ) }\end{array}$ & $\begin{array}{l}\text { moderately depressed; very strongly embracing } \\
\text { (ww/wh } \sim 1.60 ; \text { IZR } \sim 0.47 \text { ) }\end{array}$ & $\begin{array}{l}\text { moderate } \\
(\text { WER } \sim 1.85)\end{array}$ \\
\hline $10 \mathrm{~mm}$ & $\begin{array}{l}\text { thickly pachyconic; subinvolute } \\
\text { (ww/dm } \sim 0.74 ; \text { uw/dm } \sim 0.20 \text { ) }\end{array}$ & $\begin{array}{l}\text { moderately depressed; strongly embracing } \\
\text { (ww/wh } \sim 1.55 ; \text { IZR } \sim 0.40 \text { ) }\end{array}$ & $\begin{array}{l}\text { moderate } \\
(\mathrm{WER}=1.80-2.00)\end{array}$ \\
\hline $30 \mathrm{~mm}$ & $\begin{array}{l}\text { thickly discoidal; subinvolute } \\
\text { (ww/dm }=0.48-0.55 ; \mathrm{uw} / \mathrm{dm}=0.15-0.20)\end{array}$ & $\begin{array}{l}\text { weakly depressed; strongly embracing } \\
\text { (ww/wh } \sim 1.05 ; \text { IZR } \sim 0.42 \text { ) }\end{array}$ & $\begin{array}{l}\text { moderate } \\
(\mathrm{WER}=1.85-1.95)\end{array}$ \\
\hline $60 \mathrm{~mm}$ & $\begin{array}{l}\text { thinly discoidal; subinvolute } \\
\text { (ww/dm } \sim 0.46 ; \text { uw/dm } \sim 0.22 \text { ) }\end{array}$ & $\begin{array}{l}\text { weakly depressed; strongly embracing } \\
\text { (ww/wh } \sim 1.05 ; \text { IZR } \sim 0.45 \text { ) }\end{array}$ & $\begin{array}{l}\text { moderate } \\
(\mathrm{WER}=1.75-1.85)\end{array}$ \\
\hline $90 \mathrm{~mm}$ & $\begin{array}{l}\text { thinly discoidal; subinvolute } \\
\text { (ww/dm } \sim 0.41 ; \text { uw/dm } \sim 0.25 \text { ) }\end{array}$ & $\begin{array}{l}\text { weakly compressed; strongly embracing } \\
\text { (ww/wh } \sim 1.00 ; \text { IZR } \sim 0.42 \text { ) }\end{array}$ & $\begin{array}{l}\text { moderate } \\
(\mathrm{WER} \sim 1.75)\end{array}$ \\
\hline
\end{tabular}

Table 119. Conch dimensions (in $\mathrm{mm}$ ) and proportions for reference specimens of Rotopericyclus lubesederi $\mathrm{n}$. sp.

\begin{tabular}{|c|c|c|c|c|c|c|c|c|c|c|}
\hline & $d m$ & wW & wh & uW & ah & $w w / d m$ & ww/wh & $\mathrm{uw} / \mathrm{dm}$ & WER & IZR \\
\hline paratype MB.C.18809.3 & 86.9 & 35.7 & 38.6 & 18.5 & 21.7 & 0.41 & 0.92 & 0.21 & 1.78 & 0.44 \\
\hline holotype MB.C.18809.1 & 51.8 & 24.9 & 23.2 & 10.7 & 14.0 & 0.48 & 1.07 & 0.21 & 1.88 & 0.40 \\
\hline paratype MB.C.18809.2 & 47.2 & 21.0 & 23.0 & 8.9 & 13.2 & 0.45 & 0.91 & 0.19 & 1.93 & 0.43 \\
\hline paratype MB.C.18809.4 & 46.6 & 23.0 & 20.8 & 9.5 & 12.7 & 0.49 & 1.10 & 0.20 & 1.89 & 0.39 \\
\hline
\end{tabular}

Table 120. Suture line proportions (Fig. 82D) for Rotopericyclus lubesederi n. sp.

\begin{tabular}{llllllll}
\hline specimen & at dm & EL w/d & EL/VLS & EL/AL & MS h & VLS w/h & remarks \\
\hline paratype MB.C.18809.2 & c. $30.0 \mathrm{~mm}$ & 0.42 & 0.67 & 0.81 & 0.25 & 0.63 flanks of A lobe almost straight \\
\hline
\end{tabular}
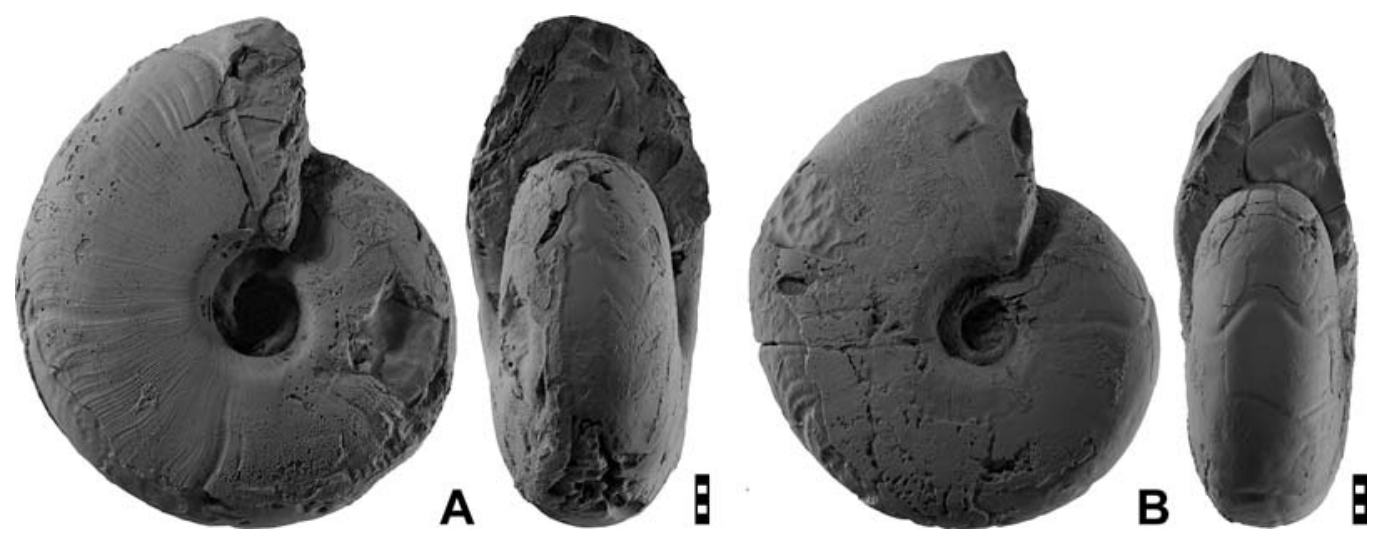

Figure 81. Rotopericyclus lubesederi n. sp. from locality MOU-C1; all ×1. A. Holotype MB.C.18809.1. B. Paratype MB.C.18809.2. 
Discussion. Rotopericyclus lubesederi is the species of the genus that shows the closest similarities to Muensteroceras. However, the conch ontogeny shows changes such as the adult opening of the umbilicus, which is not present in Muensteroceras. Similarities can be seen in the suture line with an almost parallel-sided external lobe and the ornament that consists of slightly biconvex growth lines and constrictions.

Rotopericyclus lubesederi is similar to R. subplicatilis and $R$. foordi, but differs in the narrower umbilicus (at about $90 \mathrm{~mm} \mathrm{dm}$ : uw/dm $\sim 0.26$ in R. subplicatilis, 0.30 in $R$. foordi, but 0.20 in $R$. lubesederi). Both species have a stouter conch than $R$. lubesederi (at about $90 \mathrm{~mm} \mathrm{dm}$ : ww/dm $\sim 0.45$ in $R$. subplicatilis, 0.45 in $R$. foordi, but 0.40 in $R$. lubesederi).
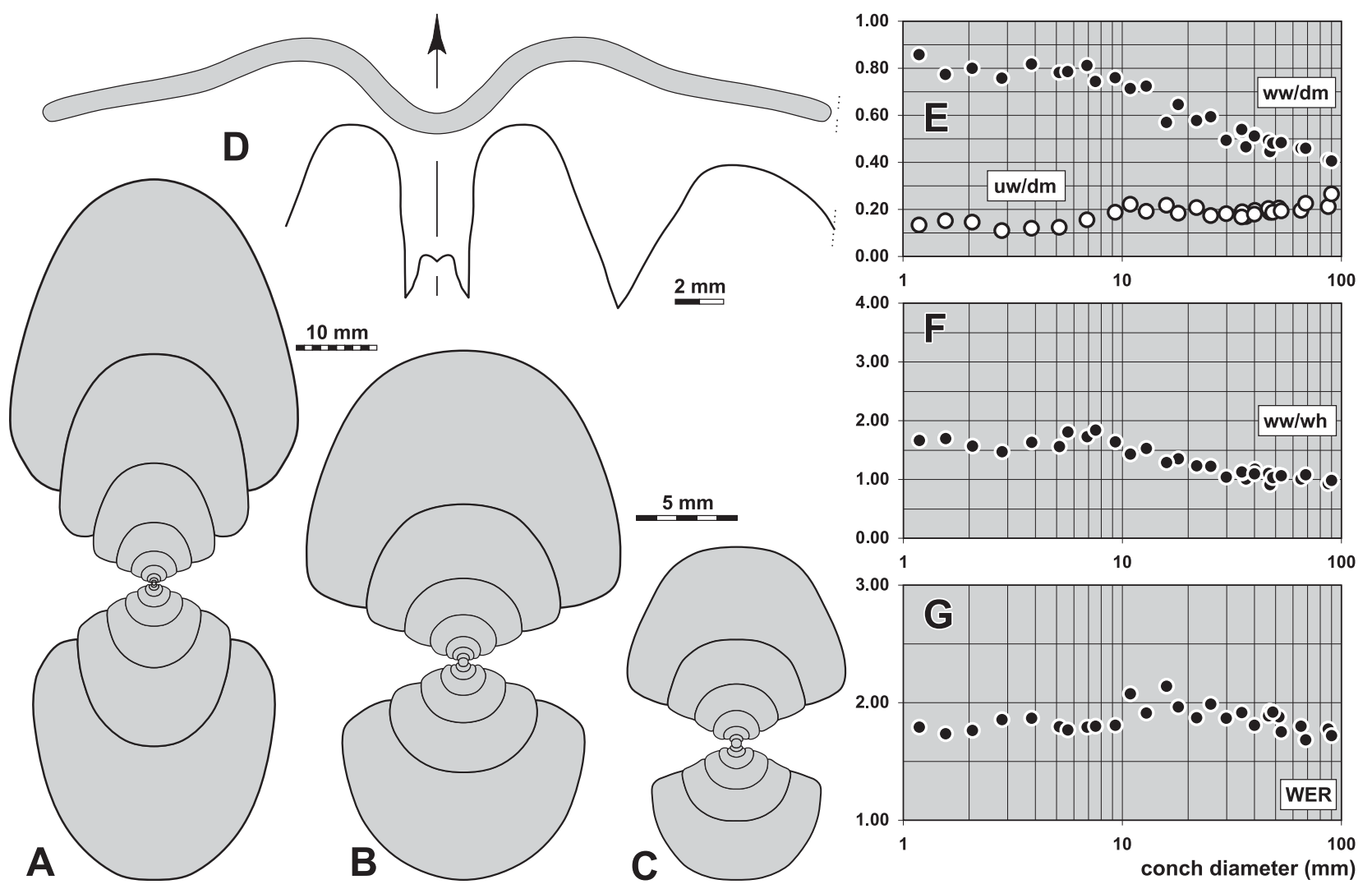

Figure 82. Rotopericyclus lubesederi n. sp. A. Cross section of paratype MB.C.18809.3 from locality MOU-C1; $\times 1.0$. B. Cross section of the inner whorls or the same specimen; $\times 2.5$. C. Cross section of paratype MB.C.18816 from locality MOU-C2; $\times 2.5$. D. Suture line and constriction of paratype MB.C.18809.2 from locality MOU-C1, at $14.8 \mathrm{~mm} \mathrm{ww}, 14.7 \mathrm{~mm}$ wh; $\times 3.0$. E-G. Ontogenetic development of the conch width index (ww/dm), umbilical width index (uw/dm), whorl width index (ww/wh), and whorl expansion rate (WER) of all available specimens.

\section{Rotopericyclus? sp.}

Figures 83, 84

Material. 9 specimens, conch diameter up to $50 \mathrm{~mm}$. The present material does not allow the description of a distinct species. All specimens are almost smooth without constrictions; which separates it from the co-occurring species. The umbilical margin is subangular (Fig. 84A) and the umbilical wall flat. The conch ontogeny resembles that of species of Rotopericyclus or Eurites (Figs 84B, C).

Family Maxigoniatitidae Korn, Klug \& Mapes, 1999

Subfamily Dzhaprakoceratinae n. subfam.

Subfamily definition. Maxigoniatitidae with a narrowly to moderately umbilicate juvenile stage and involute or subinvolute adult stage with compressed or moderately depressed whorl cross section. Ornament usually with biconvex, fine growth lines. Suture line with parallel-sided, slightly pouched external lobe, flanks of the external lobe usually strongly sinuous.

Included genera.

Dzhaprakoceras Popov, 1965

Muensteroceratoides Popov, 1965 (synonym of Dzhaprakoceras Popov, 1965) 
Discussion. The morphological evolution within the family Maxigoniatitidae includes the widening of the external lobe, which is still parallel-sided in the first representatives of the family. This plesiomorphic condition is maintained in the conservative lineage (Dzhaprakoceratinae n. subfam.) until the Late Viséan (genera Eoglyphioceras Brüning, 1923 and Beyrichoceratoides Bisat, 1924, from which the synonymy conditions still have to be solved).
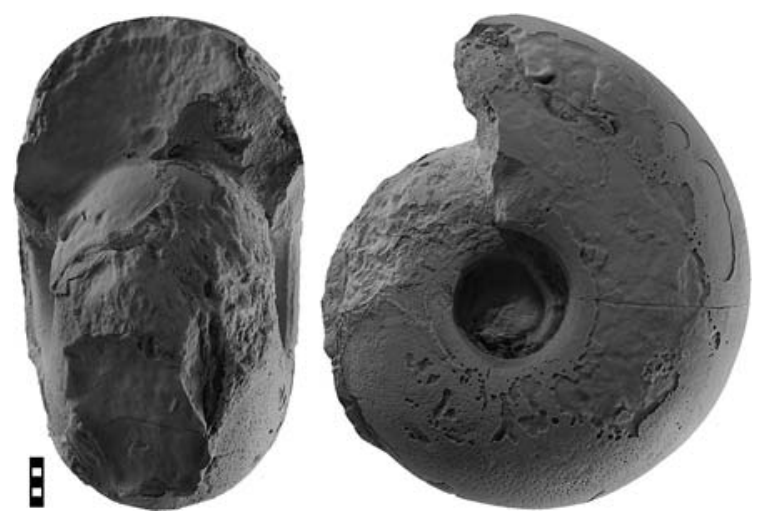

Figure 83. Rotopericyclus? sp., specimen MB.C.18741.1 from locality MOU-C1; $\times 1$.
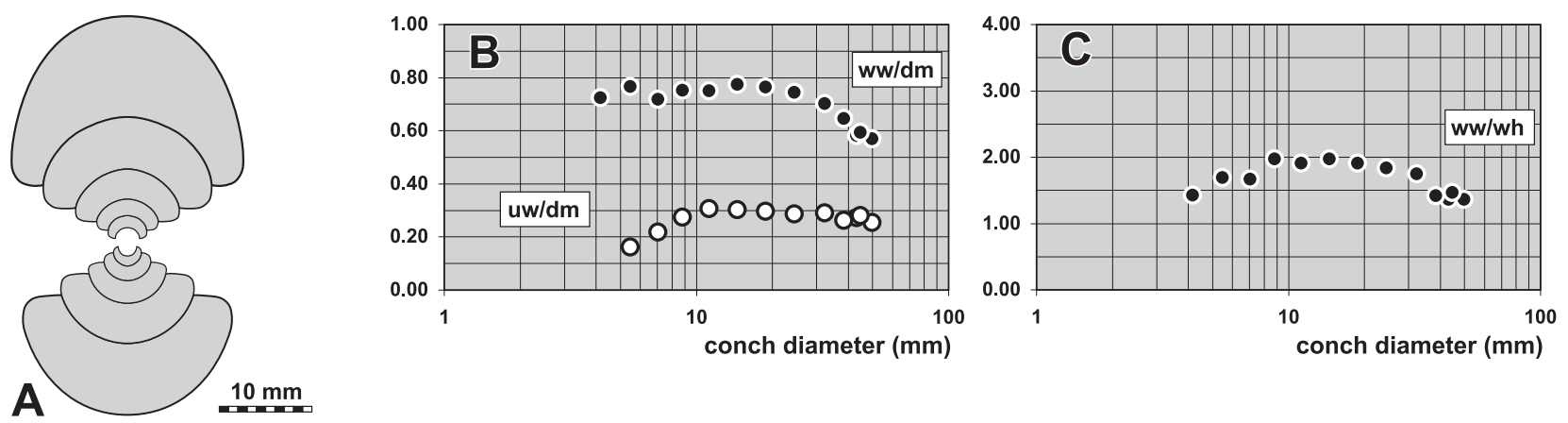

Figure 84. Rotopericyclus? sp. from locality MOU-C1. A. Cross section of specimen MB.C.18741.2; ×1.0. B, C. Ontogenetic development of the conch width index (ww/dm), umbilical width index (uw/dm), and whorl width index (ww/wh), of the available specimens.

\section{Dzhaprakoceras Popov, 1965}

Type species. Muensteroceras tianshanicum Librovitch, 1927 (OD).

Genus definition. Maxigoniatitidae with insignificant ontogenetic changes in the conch; shape pachyconic or discoidal, involute or subinvolute with an ontogenetic tendency for lateral compression of the conch and closure of the umbilicus; flanks moderately strong converging towards the rounded venter; umbilical wall and umbilical margin rounded; aperture high in the adult stage. Ornament with very fine, biconvex rectiradiate growth lines with moderately high ventrolateral projection and rather deep ventral sinus; sometimes with shell constrictions parallel to the growth lines. Suture line with very narrow, slightly pouched external lobe and very low or low median saddle; ventrolateral saddle broadly rounded and usually strikingly asymmetric; adventive lobe V-shaped, usually asymmetric with almost straight or concave ventral side and convex dorsal side.

Included species.

aksuense: Muensteroceratoides aksuensis Popov, 1965, p. 37; Tien Shan.

amplum: Dzhaprakoceras amplum n. sp.; Mouydir, Algeria.

angustum: Dzhaprakoceras angustum Kusina \& Konovalova, 2004, p. 15; North Urals.

arkansanum: Muensteroceras arkansanum Gordon, 1965, p. 177; Arkansas.

belcourtense: Dzhaprakoceras belcourtense Work \& Nassichuk, 2000, p. 44; British Columbia.

biconvexum: Dzhaprakoceras biconvexum n. sp.; Mouydir, Algeria.

catena: Dzhaprakoceras catena Riley, 1996, p. 53; Lancashire.

chermnykhi: Dzhaprakoceras chermnykhi Kusina, 1980, p. 51; North Urals.

crassum: Dzhaprakoceras crassum Work \& Nassichuk, 2000, p. 45; British Columbia.

deflexum: Dzhaprakoceras deflexum Kusina, 1980, p. 58; North Urals.

djaprakense: Muensteroceras djaprakense Librovitch, 1927, p. 37; Tien Shan.

duponti: Munsteroceras duponti Delépine, 1940, p. 58; Belgium.

dzhazairense: Dzhaprakoceras dzhazairense Ebbighausen, Korn \& Bockwinkel, 2010; Gourara, Algeria. 
flexiforme: Dzhaprakoceras flexiforme Kusina \& Konovalova, 2004, p. 15; North Urals.

flexum: Dzhaprakoceras flexum Riley, 1996, p. 58; Lancashire.

flexuosum: Nautellipsites pseudoparallelus forma flexuosa Pareyn, 1961, p. 106; Saoura Valley. [synonym of D. hispanicum] glabrum: Dzhaprakoceras glabrum Kusina \& Konovalova, 2004, p. 13; North Urals.

gordoni: Dzhaprakoceras gordoni Petersen, Korn \& Kullmann, 2000, p. 885; Utah.

gracile: Dzhaprakoceras gracile Kusina in Shimansky \& Kusina, 1977, p. 87; North Urals.

hibernicum: Nautellipsites hibernicus Delépine, 1940, p. 164; Ireland.

hispanicum: Glyphioceras hispanicum Foord \& Crick, 1903, p. 190; Cantabrian Mountains.

humile: Münsteroceras humile Schindewolf, 1951, p. 62; Harz.

improcerum: Dzhaprakoceras improcerum Kusina, 1980, p. 50; North Urals.

latilobatum: Dzhaprakoceras latilobatum Kusina, 1983, p. 93; North Urals.

levis: Dzhaprakoceras levis Riley, 1996, p. 61; Lancashire.

narynense: Bollandites narynensis Popov, 1965, p. 39; Tien Shan.

paracatena: Dzhaprakoceras paracatena Riley, 1996, p. 63; Lancashire.

planum: Dzhaprakoceras planum Kusina \& Yatskov, MB.C.18884.1, p. 103; Novaya Zemlya.

procerum: Münsteroceras procerum Schindewolf, 1951, p. 57; Harz.

pseudoparallelum: Nautellipsites pseudoparallelus Delépine, 1940, p. 54; Anti-Atlas.

punctum: Dzhaprakoceras punctum n. sp.; Mouydir, Algeria.

quantulum: Dzhaprakoceras quantulum Kusina \& Yatskov, MB.C.18884.1, p. 104; Novaya Zemlya.

shabyrense: Bollandites shabyrensis Popov, 1968, p. 93; Tien Shan.

sonkulicum: Muensteroceras kazahstanicum var. sonkulica Librovitch, 1940, p. 32; Karaganda.

subglobosum: Muensteroceras subglobosum Librovitch, 1927, p. 35; Tien Shan.

subquadratum: Glyphioceras (Beyrichoceras) subquadratum Foord, 1903, p. 172; Ireland. [synonym of D. koninckianum] subtile: Dzhaprakoceras subtile Kusina, 1980, p. 54; North Urals.

subtruncatum: Glyphioceras (Beyrichoceras) subtruncatum Foord, 1903, p. 168; Ireland. [synonym of D. koninckianum]

tianshanicum: Muensteroceras tianshanicum Librovitch, 1927, p. 33; Tien Shan.

vergum: Dzhaprakoceras vergum n. sp.; Mouydir, Algeria.

? difficile: Glyphioceras (Beyrichoceras) difficile Foord, 1903, p. 171; Ireland.

? kokdzharensis: ?Bollandites kokdzharensis Popov, 1965, p. 41; Tien Shan.

Separation of the new species. The four species of Dzhaprakoceras from Oued Temertasset can be separated by their conch morphology, steinkern surface, and suture line. In the conch shape and its ontogenetic development, they are characterised as follows:

- D. punctum - ww/dm stable at $0.80-0.90$ from $1 \mathrm{~mm}$ to $8 \mathrm{~mm}$, thereafter decrease to $\sim 0.65$ at $15 \mathrm{~mm} \mathrm{dm;} \mathrm{uw/dm} \sim 0.20$ in the initial stage, continuous decrease to 0.05 at $15 \mathrm{~mm}$ dm; umbilical margin rounded;

- D. amplum - ww/dm decreasing from $\sim 0.80$ at $2 \mathrm{~mm} \mathrm{dm}$ to $\sim 0.40$ at $35 \mathrm{~mm} \mathrm{dm}$; uw/dm decreasing from $\sim 0.30$ at $2 \mathrm{~mm}$ dm to $\sim 0.10$ at $7 \mathrm{~mm} \mathrm{dm}$; umbilical margin rounded;

- D. vergum - ww/dm continuously decreasing from $\sim 0.80$ at $1 \mathrm{~mm}$ dm to 0.40 at $25 \mathrm{~mm}$; uw/dm decreasing from $\sim 0.25$ at $2 \mathrm{~mm} \mathrm{dm}$ to $=0.10-0.20$ at $8 \mathrm{~mm} \mathrm{dm}$ and then remaining in these limits; umbilical margin subangular;

- D. biconvexum - ww/dm continuously decreasing from $\sim 0.90$ at $1 \mathrm{~mm} \mathrm{dm}$ to 0.40 at $40 \mathrm{~mm}$; uw/dm continuously decreasing from $\sim 0.20$ at $2 \mathrm{~mm}$ dm to $=0.05-0.15$ at $40 \mathrm{~mm} \mathrm{dm}$; umbilical margin rounded or subangular.

The steinkern surface differs in the four specimens:

- D. punctum - without constrictions;

- D. amplum - numerous concavo-convex constrictions;

- D. vergum - numerous biconvex constrictions;

- D. biconvexum - deep biconvex constrictions.

The suture line offers more distinguishing characters:

- D. punctum - external lobe very narrow (EL w/d less than 0.40), flanks slightly curved, ventrolateral saddle slightly asymmetric, adventive lobe with convex flanks;

- D. amplum - external lobe narrow (EL w/d about 0.50), flanks almost straight, ventrolateral saddle narrowly rounded and strongly asymmetric, adventive lobe V-shaped with concave ventral and convex dorsal flank;

- D. vergum - external lobe very narrow (EL w/d less than 0.40 ), flanks moderately curved, ventrolateral saddle broadly rounded and strongly asymmetric, adventive lobe V-shaped with concave ventral and convex dorsal flank;

- D. biconvexum - external lobe very narrow (EL w/d less than 0.40 in the adult stage but 0.50 in juveniles), flanks moderately curved, ventrolateral saddle slightly asymmetric and broadly rounded, adventive lobe with convex flanks.

Discussion. The species list shows that Dzhaprakoceras had an almost global distribution. The numerous species are very similar in their conch shape (usually thickly discoidal and involute or subinvolute) and they share a similar suture line.

Dzhaprakoceras was probably the first Carboniferous ammonoid that possessed a subparallel-sided, slightly pouched external lobe. It was thus, by Korn et al. (1999), placed in the new family Maxigoniatitidae, which is characterised by sinuous flanks of the external lobe and hook-shaped secondary prongs. However, it is not certain that this character emerged only once in the evolution of the Early Carboniferous ammonoids.

It appears to be clear that Muensteroceras is a close relative to Dzhaprakoceras, but it is not clear which genus is the plesiomorphic one. Generally it was accepted that Dzhaprakoceras is the derived genus, but this opinion may be wrong. 


\section{Dzhaprakoceras vergum n. sp.}

\section{Figures 85,86}

Derivation of name. From Latin vergum $=$ inclined, because of the shape of the ventrolateral saddle.

Holotype. Specimen MB.C.19028.1, illustrated in Figure 85A.

Type locality and horizon. Oued Temertasset, locality and sample MOU-V (Mouydir, South Algeria); lower part of the Pericyclus-Progoniatites Assemblage.

Material. 874 specimens, conch diameter up to $29 \mathrm{~mm}$.

Diagnosis. Dzhaprakoceras with thickly pachyconic conch in early juveniles, thereafter continuous transformation into a thinly discoidal conch at $20 \mathrm{~mm} \mathrm{dm}$; conch subinvolute in the early juvenile stage and involute at $8 \mathrm{~mm} \mathrm{dm}$, slight re-opening of the umbilicus in the adult stage (conch involute or subinvolute); umbilicus funnel-shaped, umbilical margin subangular, umbilical wall flattened and oblique; aperture low in juveniles and moderately high to high above $6 \mathrm{~mm} \mathrm{dm}$. Steinkern with sharp constrictions, course slightly concavo-convex with very shallow lateral sinus and deep ventral sinus; weak riblets occur occasionally between the constrictions. Suture line with very narrow, slightly pouched external lobe and very low median saddle; ventrolateral saddle rounded and strongly asymmetric; adventive lobe V-shaped, strikingly asymmetric with concave ventral side and convex dorsal side.

Table 121. Conch ontogeny (Figs 86A-F, I-K) of Dzhaprakoceras vergum n. sp.

\begin{tabular}{|c|c|c|c|}
\hline$d m$ & conch shape & whorl cross section shape & aperture \\
\hline $2 \mathrm{~mm}$ & $\begin{array}{l}\text { thickly pachyconic; subinvolute } \\
(\mathrm{ww} / \mathrm{dm}=0.75-0.85 ; \mathrm{uw} / \mathrm{dm}=0.22-0.30)\end{array}$ & $\begin{array}{l}\text { moderately depressed; very strongly embracing } \\
(\mathrm{ww} / \mathrm{wh}=1.75-2.00 ; \mathrm{IZR}=0.45-0.50)\end{array}$ & $\begin{array}{l}\text { low } \\
(\text { WER }=1.65-1.75)\end{array}$ \\
\hline $8 \mathrm{~mm}$ & $\begin{array}{l}\text { thickly discoidal to thinly pachyconic; involute } \\
\text { (ww/dm }=0.50-0.65 ; \mathrm{uw} / \mathrm{dm} 0.08-0.15 \text { ) }\end{array}$ & $\begin{array}{l}\text { weakly compressed to weakly depressed; strongly } \\
\text { embracing ( } w w / w h=0.90-1.25 ; I Z R=0.40-0.45)\end{array}$ & $\begin{array}{l}\text { moderate to high } \\
(\mathrm{WER}=1.90-2.10)\end{array}$ \\
\hline $20 \mathrm{~mm}$ & $\begin{array}{l}\text { thinly discoidal; involute or subinvolute } \\
(\mathrm{ww} / \mathrm{dm}=0.40-0.50 ; \mathrm{uw} / \mathrm{dm}=0.10-0.20)\end{array}$ & $\begin{array}{l}\text { weakly compressed; strongly embracing } \\
(\mathrm{ww} / \mathrm{wh}=0.80-1.00 ; \mathrm{IZR}=0.35-0.45)\end{array}$ & $\begin{array}{l}\text { moderate to high } \\
(\mathrm{WER}=1.85-2.15)\end{array}$ \\
\hline
\end{tabular}

Table 122. Conch dimensions (in $\mathrm{mm}$ ) and proportions for reference specimens of Dzhaprakoceras vergum $\mathrm{n}$. sp.

\begin{tabular}{lllllllllll}
\hline & $\mathrm{dm}$ & $w w$ & $w h$ & uw & ah & ww/dm & ww/wh & uw/dm & WER & IZR \\
\hline holotype MB.C.19028.1 & 19.5 & 8.3 & 9.8 & 2.9 & 5.9 & 0.43 & 0.85 & 0.15 & 2.04 & 0.40 \\
paratype MB.C.19028.2 & 17.8 & 8.6 & 8.3 & 2.6 & 5.2 & 0.48 & 1.04 & 0.14 & 2.00 & 0.37 \\
paratype MB.C.19028.3 & 13.9 & 7.2 & 7.6 & 1.2 & 4.2 & 0.52 & 0.95 & 0.09 & 2.04 & 0.45 \\
paratype MB.C.19028.4 & 11.1 & 5.8 & 5.6 & 1.1 & 3.3 & 0.52 & 1.04 & 0.10 & 2.02 & 0.41 \\
\hline
\end{tabular}

Table 123. Suture line proportions (Figs $86 \mathrm{G}, \mathrm{H}$ ) for Dzhaprakoceras vergum $\mathrm{n}$. $\mathrm{sp}$.

\begin{tabular}{llllllll}
\hline specimen & at $\mathrm{dm}$ & EL w/d & EL/VLS & EL/AL & MS h & VLS w/h & remarks \\
\hline holotype MB.C.19028.1 & $19.4 \mathrm{~mm}$ & 0.40 & 0.51 & 0.80 & 0.20 & 0.78 & A lobe strikingly asymmetric \\
paratype MB.C.19028.3 & $12.3 \mathrm{~mm}$ & 0.37 & 0.54 & 0.66 & 0.19 & 0.69 & A lobe slightly asymmetric \\
\hline
\end{tabular}

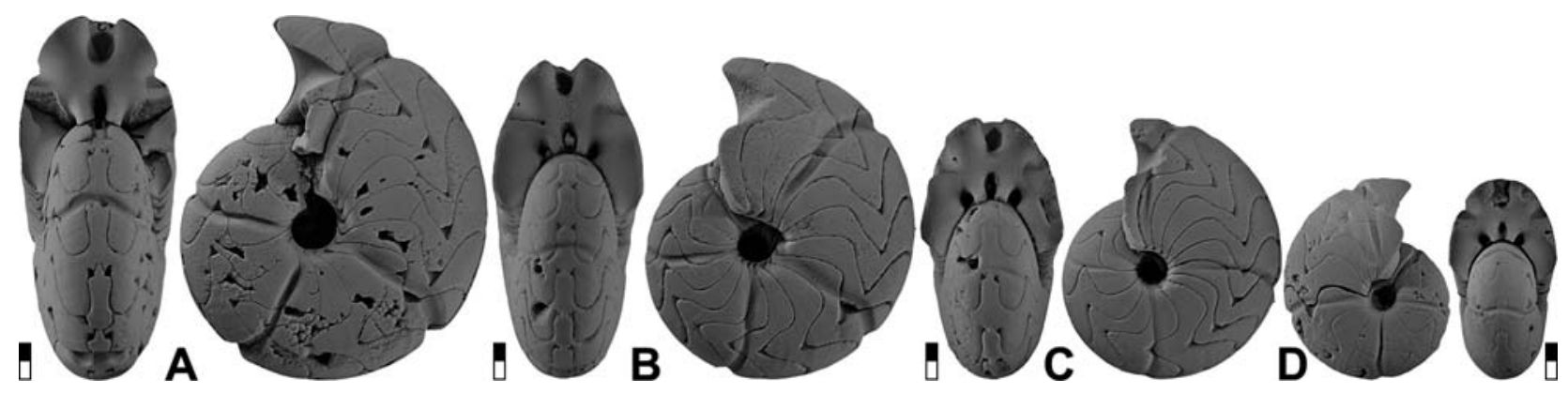

Figure 85. Dzhaprakoceras vergum n. sp. from locality MOU-V; all $\times 2$. A. Holotype MB.C.19028.1. B. Paratype MB.C.19028.2. C. Paratype MB.C.19028.3. D. Paratype MB.C.19028.4. 
Discussion. Dzhaprakoceras vergum shows only slightly curved flanks of the E lobe and can thus be regarded as a rather basal member of the genus. Apart from the slightly pouched external lobe, it resembles Muensteroceras quadriconstrictum from the Anti-Atlas.

The strong steinkern constrictions of D. vergum help to separate the new species from other species with a similar conch morphology, such as D. tianshanicum and D. dzhazairense. Another separating criterion is the umbilicus, which is narrower in D. tianshanicum, D. chermnykhi, D. gracile, D. hispanicum, D. pseudoparallelum, D. belcourtense, and D. dzhazairense (uw/dm is in the adult stage less than 0.10).
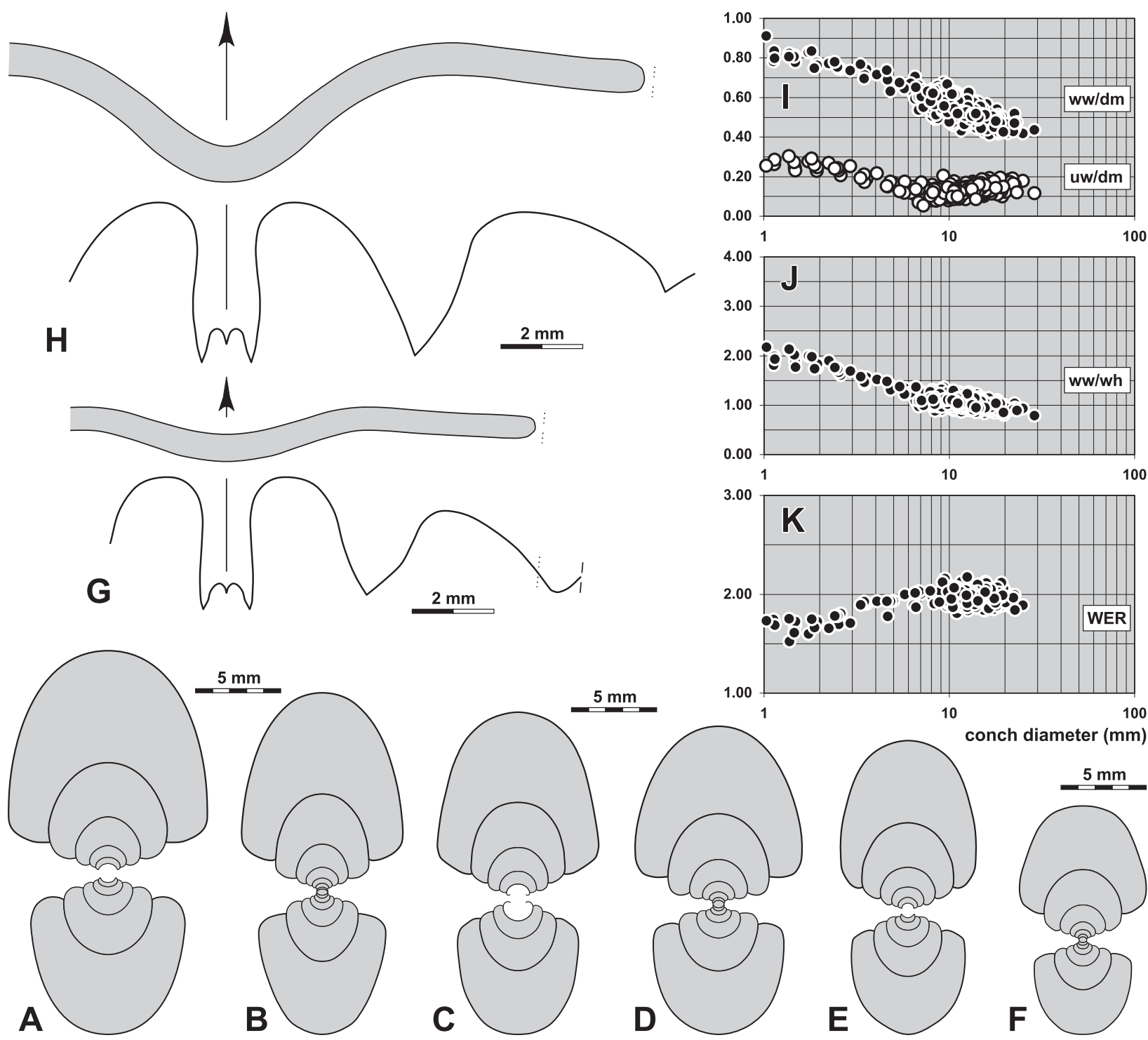

Figure 86. Dzhaprakoceras vergum n. sp. A. Cross section of paratype MB.C.19028.5 from locality MOU-V; $\times 2.5$. B. Cross section of paratype MB.C.19028.6 from locality MOU-V; $\times 2.5$. C. Cross section of paratype MB.C.18875.1 from locality MOU-D1; $\times 2.5$. D. Cross section of paratype MB.C.19028.7 from locality MOU-V; $\times 2.5$. E. Cross section of paratype MB.C.18875.2 from locality MOU-D1; $\times 2.5$. F. Cross section of paratype MB.C.18922.1 from locality MOU-E03; $\times 2.5$. G. Suture line and constriction of paratype MB.C.19028.3 from locality MOU-V, at $12.3 \mathrm{~mm} \mathrm{dm}, 7.2 \mathrm{~mm} w w, 6.7 \mathrm{~mm} w \mathrm{wh} \times 6.0$. H. Suture line and constriction of holotype MB.C.19028.1 from locality MOU-V, at $19.4 \mathrm{~mm} \mathrm{dm}, 8.4 \mathrm{~mm} w w, 10.1 \mathrm{~mm} w \mathrm{w} ; \times 6.0$. I-K. Ontogenetic development of the conch width index (ww/dm), umbilical width index (uw/dm), whorl width index (ww/wh), and whorl expansion rate (WER) of all available specimens. 


\section{Dzhaprakoceras amplum n. sp.}

\section{Figures 87,88}

Derivation of name. From Latin amplum $=$ wide, because of the comparatively wide external lobe.

Holotype. Specimen MB.C.18912.1, illustrated in Figure 87.

Type locality and horizon. Oued Temertasset, locality and sample MOU-D3 (Mouydir, South Algeria); Helicocyclus-Ouaoufilalites Assemblage. Material. 20 specimens, conch diameter up to $36 \mathrm{~mm}$.

Diagnosis. Dzhaprakoceras with thickly pachyconic and subinvolute conch in the early juvenile stage, thereafter almost continuous transformation into a thinly discoidal and involute conch at $30 \mathrm{~mm} \mathrm{dm}$; umbilical margin rounded, umbilical wall convex; aperture moderate in juveniles and high above $8 \mathrm{~mm} \mathrm{dm}$. Steinkern usually without constrictions. Suture line with narrow, slightly pouched external lobe and low median saddle; ventrolateral saddle narrowly rounded and asymmetric; adventive lobe V-shaped, asymmetric with steep ventral flank.

Table 124. Conch ontogeny (Figs 88A, D-F) of Dzhaprakoceras amplum n. sp.

\begin{tabular}{|c|c|c|c|}
\hline $\mathrm{dm}$ & conch shape & whorl cross section shape & aperture \\
\hline $2 \mathrm{~mm}$ & $\begin{array}{l}\text { thickly pachyconic; subinvolute } \\
\text { (ww/dm } \sim 0.80 ; \text { uw/dm } \sim 0.20 \text { ) }\end{array}$ & $\begin{array}{l}\text { moderately depressed; strongly embracing } \\
\text { (ww/wh } \sim 1.70 ; \text { IZR } \sim 0.44 \text { ) }\end{array}$ & $\begin{array}{l}\text { moderate } \\
(\text { WER } \sim 1.85)\end{array}$ \\
\hline $8 \mathrm{~mm}$ & $\begin{array}{l}\text { thinly pachyconic; involute } \\
\text { (ww/dm } \sim 0.65 ; \text { uw/dm } \sim 0.08 \text { ) }\end{array}$ & $\begin{array}{l}\text { weakly depressed; strongly embracing } \\
\text { (ww/wh } \sim 1.10 ; \text { IZR } \sim 0.44 \text { ) }\end{array}$ & $\begin{array}{l}\text { high } \\
(\text { WER } \sim 2.10)\end{array}$ \\
\hline $20 \mathrm{~mm}$ & $\begin{array}{l}\text { thickly discoidal; involute } \\
\text { (ww/dm =0.50-0.55; uw/dm } \sim 0.10 \text { ) }\end{array}$ & $\begin{array}{l}\text { weakly compressed; strongly embracing } \\
\text { (ww/wh } \sim 0.95 ; \text { IZR } \sim 0.40 \text { ) }\end{array}$ & $\begin{array}{l}\text { high } \\
\text { (WER 2.10) }\end{array}$ \\
\hline $30 \mathrm{~mm}$ & $\begin{array}{l}\text { thinly discoidal; involute } \\
\text { (ww/dm =0.40-0.48; uw/dm } \sim 0.10 \text { ) }\end{array}$ & $\begin{array}{l}\text { weakly compressed; strongly embracing } \\
\text { (ww/wh } \sim 0.85 \text {; IZR } \sim 0.40 \text { ) }\end{array}$ & $\begin{array}{l}\text { high } \\
\text { (WER 2.10) }\end{array}$ \\
\hline
\end{tabular}

Table 125. Conch dimensions (in $\mathrm{mm}$ ) and proportions for reference specimens of Dzhaprakoceras amplum $\mathrm{n}$. sp.

\begin{tabular}{lllllllllll}
\hline & $\mathrm{dm}$ & ww & wh & uw & ah & ww/dm & ww/wh & uw/dm & WER & IZR \\
\hline paratype MB.C.18900.1 & 32.1 & 14.0 & 17.8 & 2.8 & 10.0 & 0.43 & 0.78 & 0.09 & 2.12 & 0.44 \\
holotype MB.C.18912.1 & 29.7 & 13.6 & 16.3 & 2.8 & 9.1 & 0.46 & 0.83 & 0.10 & 2.08 & 0.44 \\
paratype MB.C.18912.4 & 23.7 & 11.6 & 12.5 & 3.0 & 7.6 & 0.49 & 0.93 & 0.12 & 2.15 & 0.40 \\
\hline
\end{tabular}

Table 126. Suture line proportions (Figs $88 \mathrm{~B}, \mathrm{C}$ ) for Dzhaprakoceras amplum n. sp.

\begin{tabular}{llllllll}
\hline specimen & at dm & EL w/d & EL/NLS & EL/AL & MS h & VLS w/h & remarks \\
\hline holotype MB.C.18912.1 & $29.0 \mathrm{~mm}$ & 0.50 & 0.88 & 1.21 & 0.32 & 0.57 & flanks of E lobe barely diverging \\
paratype MB.C.18912.3 & c. $22.0 \mathrm{~mm}$ & 0.52 & 0.94 & 1.23 & 0.30 & 0.56 & VL saddle narrowly rounded \\
\hline
\end{tabular}

Discussion. Dzhaprakoceras amplum is one of the few species within the genus that possesses a rather wide external lobe $(\mathrm{EL} \mathrm{w} / \mathrm{d} \sim 0.50$ in contrast to a value of less than 0.40 of many of the other species). The slender, very narrow umbilicate conch is characteristic for a number of species of Dzhaprakoceras, but the steinkern constrictions are much stronger in $D$. amplum than those of other members of the genus.
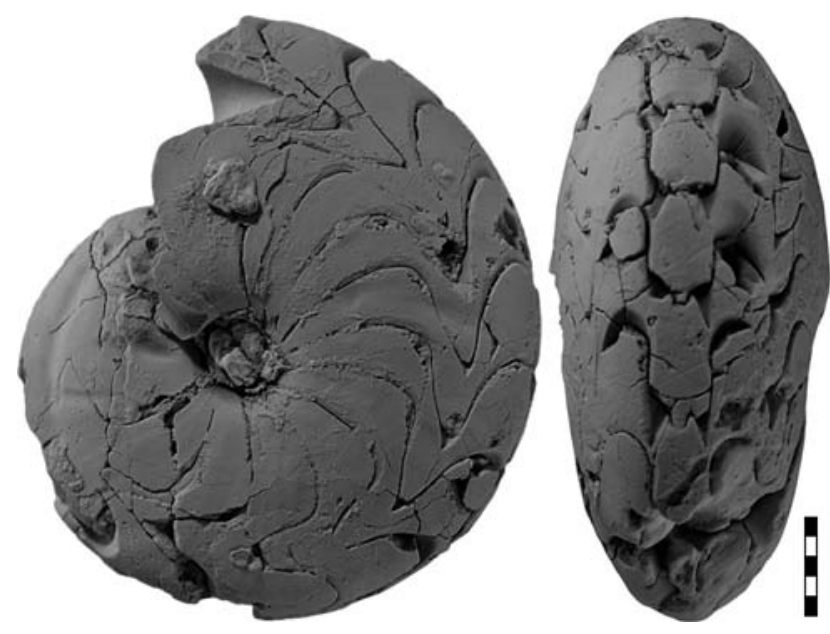

Figure 87. Dzhaprakoceras amplum n. sp., holotype MB.C.18912.1 from locality MOU-D3; $\times 2$. 

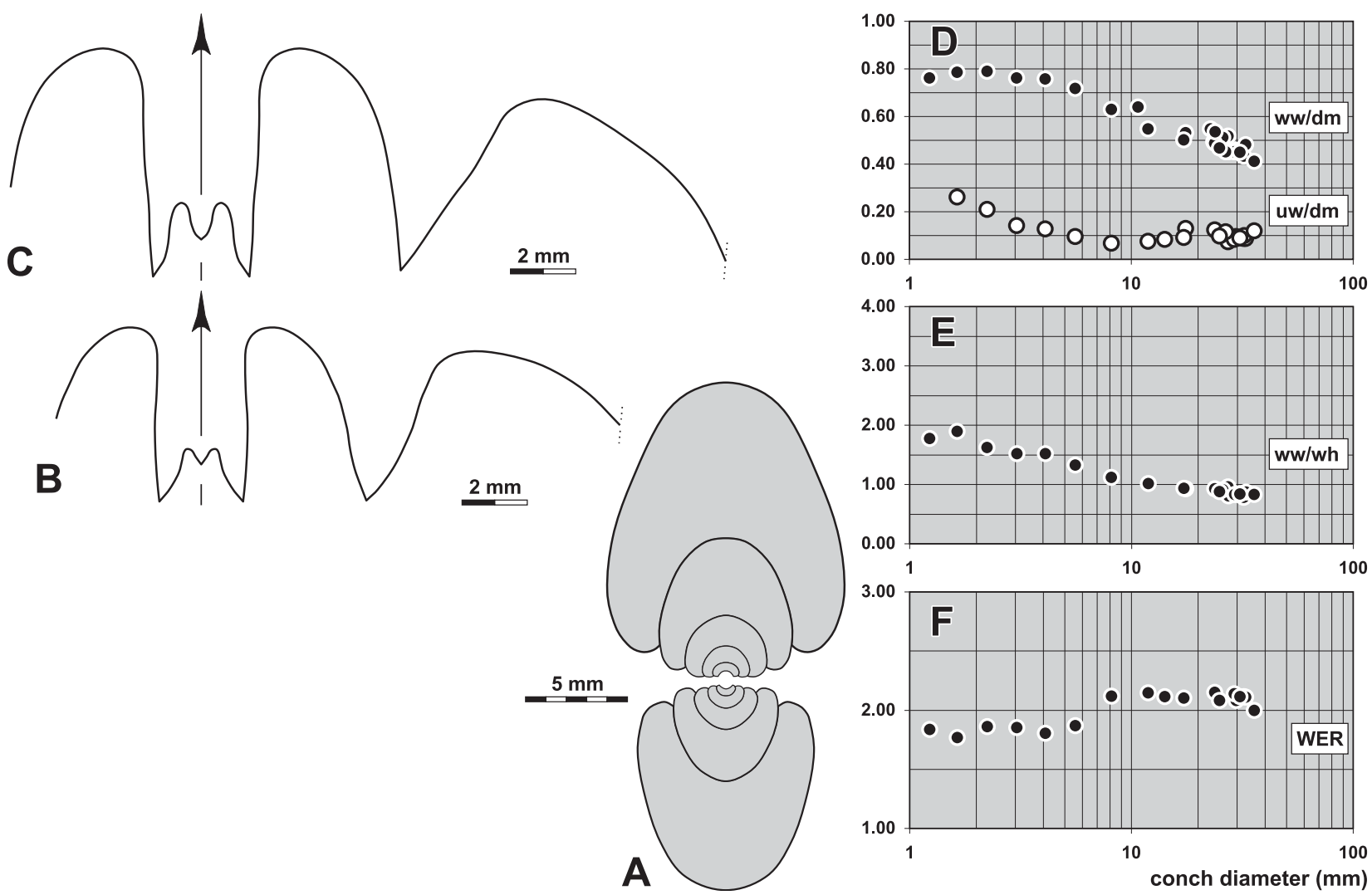

Figure 88. Dzhaprakoceras amplum n. sp. from locality MOU-D3. A. Cross section of paratype MB.C.18912.2; $\times 2.5$. B. Suture line of paratype MB.C.18912.3, at $10.5 \mathrm{~mm}$ ww, $11.8 \mathrm{~mm}$ wh; $\times 4.0$. C. Suture line of holotype MB.C.18912.1, at $29.0 \mathrm{~mm} \mathrm{dm}$, $13.6 \mathrm{~mm}$ ww, $15.2 \mathrm{~mm}$ wh; $\times$ 4.0. D-F. Ontogenetic development of the conch width index $(\mathrm{ww} / \mathrm{dm})$, umbilical width index (uw/ $\mathrm{dm})$, whorl width index (ww/wh), and whorl expansion rate (WER) of all available specimens.

\section{Dzhaprakoceras punctum n. sp.}

Figures 89, 90

Derivation of name. From Latin punctum, because of the punctiform umbilicus.

Holotype. Specimen MB.C.19050.1, illustrated in Figure 89A.

Type locality and horizon. Oued Temertasset, locality and sample MOU-Y (Mouydir, South Algeria); Helicocyclus-Ouaoufilalites Assemblage.

Material. 29 specimens, conch diameter up to $16 \mathrm{~mm}$.

Diagnosis. Dzhaprakoceras with thickly pachyconic or globular conch up to $8 \mathrm{~mm} \mathrm{dm}$, thereafter transformation into a thinly pachyconic conch at $16 \mathrm{~mm} \mathrm{dm}$; conch subinvolute in the early juvenile stage and involute above $2.5 \mathrm{~mm} \mathrm{dm}$; umbilical margin rounded, umbilical wall convex; aperture low in juveniles and high in the adult stage. Steinkern without constrictions. Suture line with very narrow, slightly pouched external lobe and low median saddle; ventrolateral saddle moderately narrowly rounded and slightly asymmetric; adventive lobe V-shaped, asymmetric.

Discussion. Dzhaprakoceras punctum differs, in its smooth steinkern without constrictions, from many of the other species of the genus. The rather stout conch and the very narrow umbilicus are further criteria for separation.

Table 127. Conch ontogeny (Figs 90A, B, F-H) of Dzhaprakoceras punctum n. sp.

\begin{tabular}{|c|c|c|c|}
\hline$d m$ & conch shape & whorl cross section shape & aperture \\
\hline $2 \mathrm{~mm}$ & $\begin{array}{l}\text { thickly pachyconic; subinvolute } \\
\text { (ww/dm } \sim 0.85 ; \text { uw/dm } \sim 0.18 \text { ) }\end{array}$ & $\begin{array}{l}\text { moderately depressed; very strongly embracing } \\
\text { (ww/wh } \sim 1.75 ; \text { IZR } \sim 0.50 \text { ) }\end{array}$ & $\begin{array}{l}\text { low } \\
(\text { WER } \sim 1.70)\end{array}$ \\
\hline $8 \mathrm{~mm}$ & $\begin{array}{l}\text { thickly pachyconic; involute } \\
\text { (ww/dm }=0.75-0.85 ; \text { uw/dm 0.07-0.12) }\end{array}$ & $\begin{array}{l}\text { moderately depressed; very strongly embracing } \\
\text { (ww/wh } \sim 1.50 \text {; IZR } \sim 0.50 \text { ) }\end{array}$ & $\begin{array}{l}\text { moderate } \\
(\mathrm{WER}=1.80-1.95)\end{array}$ \\
\hline $16 \mathrm{~mm}$ & $\begin{array}{l}\text { thinly pachyconic; involute } \\
\text { (ww/dm }=0.65-0.72 ; \text { uw/dm } \sim 0.06 \text { ) }\end{array}$ & $\begin{array}{l}\text { weakly depressed; strongly embracing } \\
\text { (ww/wh }=1.25-1.40 ; \text { IZR } \sim 0.44 \text { ) }\end{array}$ & $\begin{array}{l}\text { high } \\
\text { (WER } \sim 2.05)\end{array}$ \\
\hline
\end{tabular}


Table 128. Conch dimensions (in $\mathrm{mm}$ ) and proportions for reference specimens of Dzhaprakoceras punctum $\mathrm{n}$. sp.

\begin{tabular}{lrrrrrrrrrr}
\hline & dm & ww & wh & uw & ah & ww/dm & ww/wh & uw/dm & WER & IZR \\
\hline holotype MB.C.19050.1 & 15.5 & 10.4 & 8.5 & 0.9 & 4.8 & 0.67 & 1.23 & 0.06 & 2.09 & 0.44 \\
paratype MB.C.19050.3 & 13.1 & 9.4 & 7.4 & 0.8 & 4.0 & 0.71 & 1.27 & 0.06 & 2.05 & 0.46 \\
paratype MB.C.19050.4 & 11.9 & 8.6 & 6.9 & 0.8 & 3.5 & 0.73 & 1.26 & 0.07 & 1.99 & 0.49 \\
paratype MB.C.19050.2 & 8.7 & 6.9 & 4.7 & 0.9 & 2.2 & 0.79 & 1.47 & 0.10 & 1.81 & 0.52 \\
\hline
\end{tabular}

Table 129. Suture line proportions (Figs 90C-E) for Dzhaprakoceras punctum n. sp.

\begin{tabular}{llllllll}
\hline specimen & at $\mathrm{dm}$ & EL w/d & EL/VLS & EL/AL & MS h & VLS w/h & remarks \\
\hline holotype MB.C.19050.1 & $14.6 \mathrm{~mm}$ & 0.37 & 0.65 & 0.77 & 0.27 & 0.57 & A lobe strikingly asymmetric \\
paratype MB.C.19050.3 & $12.5 \mathrm{~mm}$ & 0.39 & 0.71 & 0.73 & 0.20 & 0.55 & M saddle comparatively low \\
paratype MB.C.19050.4 & $11.1 \mathrm{~mm}$ & 0.44 & 0.70 & 0.66 & 0.24 & 0.62 & \\
\hline
\end{tabular}

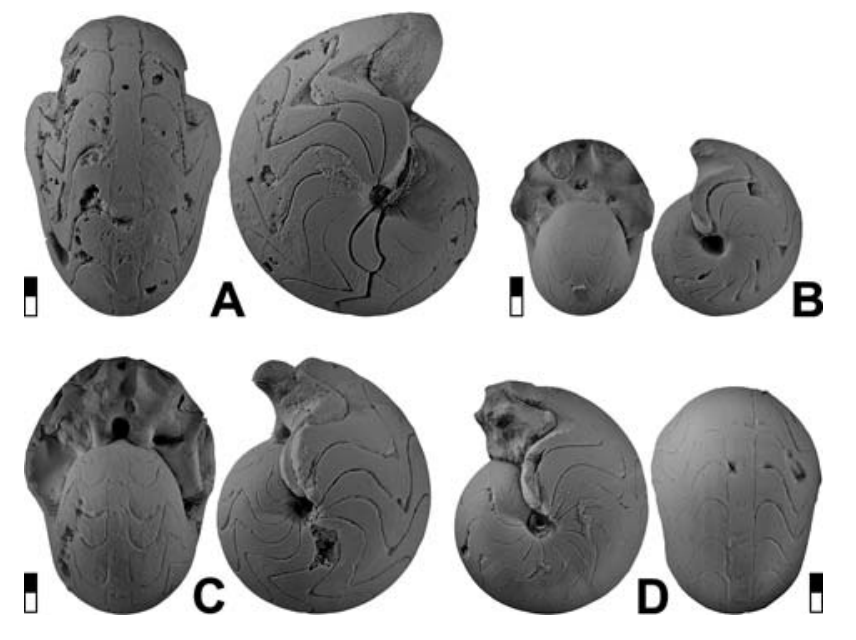

Figure 89. Dzhaprakoceras punctum n. sp. from locality MOUY; all $\times 2$. A. Holotype MB.C.19050.1. B. Paratype MB.C.19050.2. C. Paratype MB.C.19050.3. D. Paratype MB.C. 19050.4 .
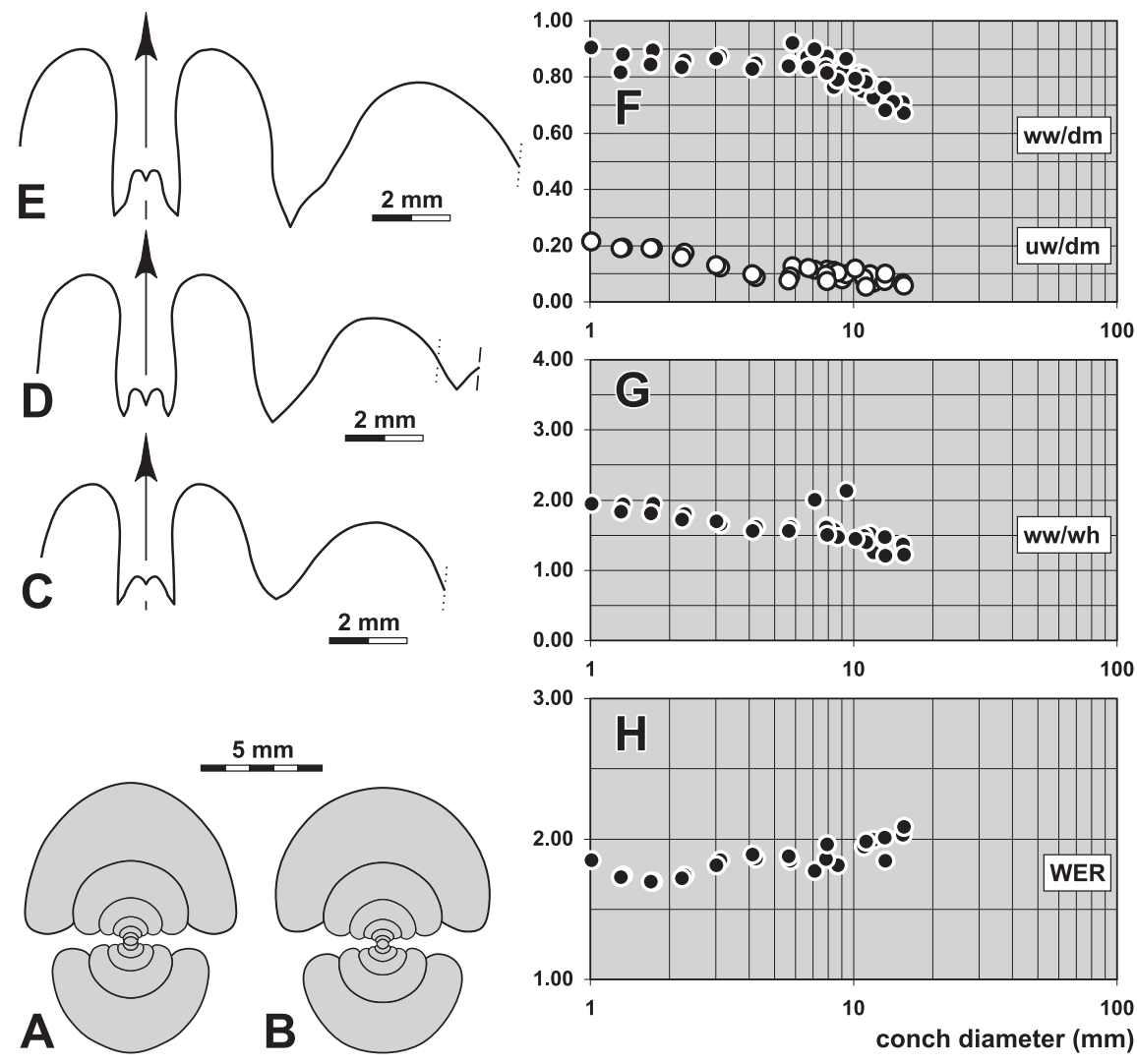

Figure 90. Dzhaprakoceras punctum n. sp. from locality MOU-Y. A. Cross section of paratype MB.C. $19050.5 ; \times 2.5$. B. Cross section of paratype MB.C.19050.6; $\times 2.5$. C. Suture line of paratype MB.C.19050.4, at $11.1 \mathrm{~mm} \mathrm{dm}$, $8.6 \mathrm{~mm}$ ww, $6.0 \mathrm{~mm}$ wh; $\times 4.0$. D. Suture line of paratype MB.C.19050.3, at $12.3 \mathrm{~mm} \mathrm{dm}$, $9.4 \mathrm{~mm}$ ww, $7.0 \mathrm{~mm}$ wh; $\times 4.0$. E. Suture line of holotype MB.C.19050.1, at $14.6 \mathrm{~mm} \mathrm{dm}$, $10.3 \mathrm{~mm} \mathrm{ww}, 8.5 \mathrm{~mm}$ wh; $\times 4.0$. FH. Ontogenetic development of the conch width index (ww/dm), umbiwidth index (ww/wh), and whorl expansion rate (WER) of all available specimens. lical width index (uw/dm), whorl 


\section{Dzhaprakoceras biconvexum n. sp.}

Figures 91, 92

Derivation of name. From Latin biconvexum, = because of the biconvex constrictions.

Holotype. Specimen MB.C.18737.1, illustrated in Figure 91A.

Type locality and horizon. Oued Temertasset, locality and sample A320-5 (Mouydir, South Algeria); Helicocyclus-Ouaoufilalites Assemblage. Material. 122 specimens, conch diameter up to $38 \mathrm{~mm}$.

Diagnosis. Dzhaprakoceras with thickly pachyconic conch in early juveniles, thereafter continuous transformation into a thinly discoidal conch at $40 \mathrm{~mm} \mathrm{dm}$; conch subinvolute in the early juvenile stage and involute in stages above $8 \mathrm{~mm} \mathrm{dm}$; umbilical margin and umbilical wall rounded; aperture moderate in juveniles and moderately high or high above $6 \mathrm{~mm} \mathrm{dm}$. Steinkern with moderately sharp constrictions, course biconvex with shallow lateral sinus and moderately deep ventral sinus. Suture line with very narrow, weakly pouched external lobe and low median saddle; ventrolateral saddle broadly rounded and slightly asymmetric; adventive lobe V-shaped, almost symmetric with slightly curved flanks.

Table 130. Conch ontogeny (Figs 92A-C, G-I) of Dzhaprakoceras biconvexum n. sp.

\begin{tabular}{|c|c|c|c|}
\hline $\mathrm{dm}$ & conch shape & whorl cross section shape & aperture \\
\hline $2 \mathrm{~mm}$ & $\begin{array}{l}\text { thickly pachyconic; subinvolute } \\
(\mathrm{w} w / \mathrm{dm}=0.80-0.85 ; \mathrm{uw} / \mathrm{dm}=0.18-0.24)\end{array}$ & $\begin{array}{l}\text { moderately depressed; strongly embracing } \\
(\mathrm{w} w / \mathrm{wh}=1.70-1.80 ; \mathrm{IZR}=0.40-0.45)\end{array}$ & $\begin{array}{l}\text { moderate } \\
(\mathrm{WER}=1.75-1.85)\end{array}$ \\
\hline $8 \mathrm{~mm}$ & $\begin{array}{l}\text { thickly pachyconic; involute or subinvolute } \\
(\mathrm{w} w / \mathrm{dm}=0.65-0.70 ; \text { uw/dm } 0.12-0.20)\end{array}$ & $\begin{array}{l}\text { weakly to moderately depressed; strongly embracing } \\
(\mathrm{ww} / \mathrm{wh}=1.30-1.65 ; \mathrm{IZR}=0.40-0.45)\end{array}$ & $\begin{array}{l}\text { moderate to high } \\
(\text { WER }=1.90-2.10)\end{array}$ \\
\hline $20 \mathrm{~mm}$ & $\begin{array}{l}\text { thickly discoidal; involute } \\
(\mathrm{ww} / \mathrm{dm}=0.50-0.60 ; \mathrm{uw} / \mathrm{dm}=0.10-0.15)\end{array}$ & $\begin{array}{l}\text { weakly depressed; strongly embracing } \\
(\mathrm{ww} / \mathrm{wh}=1.00-1.25 ; \mathrm{IZR}=0.35-0.45)\end{array}$ & $\begin{array}{l}\text { moderate to high } \\
(\mathrm{WER}=1.90-2.15)\end{array}$ \\
\hline $30 \mathrm{~mm}$ & $\begin{array}{l}\text { thinly to thickly discoidal; involute } \\
(\mathrm{ww} / \mathrm{dm}=0.44-0.52 ; \mathrm{uw} / \mathrm{dm}=0.10-0.15)\end{array}$ & $\begin{array}{l}\text { weakly compressed to weakly depressed; strongly } \\
\text { embracing ( } w w / w h=0.90-1.10 ; \mathrm{IZR}=0.40-0.45)\end{array}$ & $\begin{array}{l}\text { moderate to high } \\
(\text { WER }=1.90-2.10)\end{array}$ \\
\hline
\end{tabular}

Table 131. Conch dimensions (in $\mathrm{mm}$ ) and proportions for reference specimens of Dzhaprakoceras biconvexum $\mathrm{n}$. $\mathrm{sp}$.

\begin{tabular}{lrrrrrrrrrr}
\hline & $\mathrm{dm}$ & ww & wh & uw & ah & ww/dm & ww/wh & uw/dm & WER & IZR \\
\hline holotype MB.C.18737.1 & 33.0 & 17.5 & 15.8 & 3.5 & 9.8 & 0.53 & 1.11 & 0.11 & 2.02 & 0.38 \\
paratype MB.C.19014.1 & 21.3 & 11.2 & 10.3 & 2.5 & 6.0 & 0.52 & 1.08 & 0.12 & 1.94 & 0.42 \\
paratype MB.C.18737.2 & 19.4 & 11.5 & 9.9 & 2.8 & 5.7 & 0.59 & 1.15 & 0.15 & 2.00 & 0.43 \\
paratype MB.C.18737.6 & 10.7 & 6.8 & 5.5 & 1.2 & 3.3 & 0.63 & 1.24 & 0.11 & 2.10 & 0.39 \\
\hline
\end{tabular}
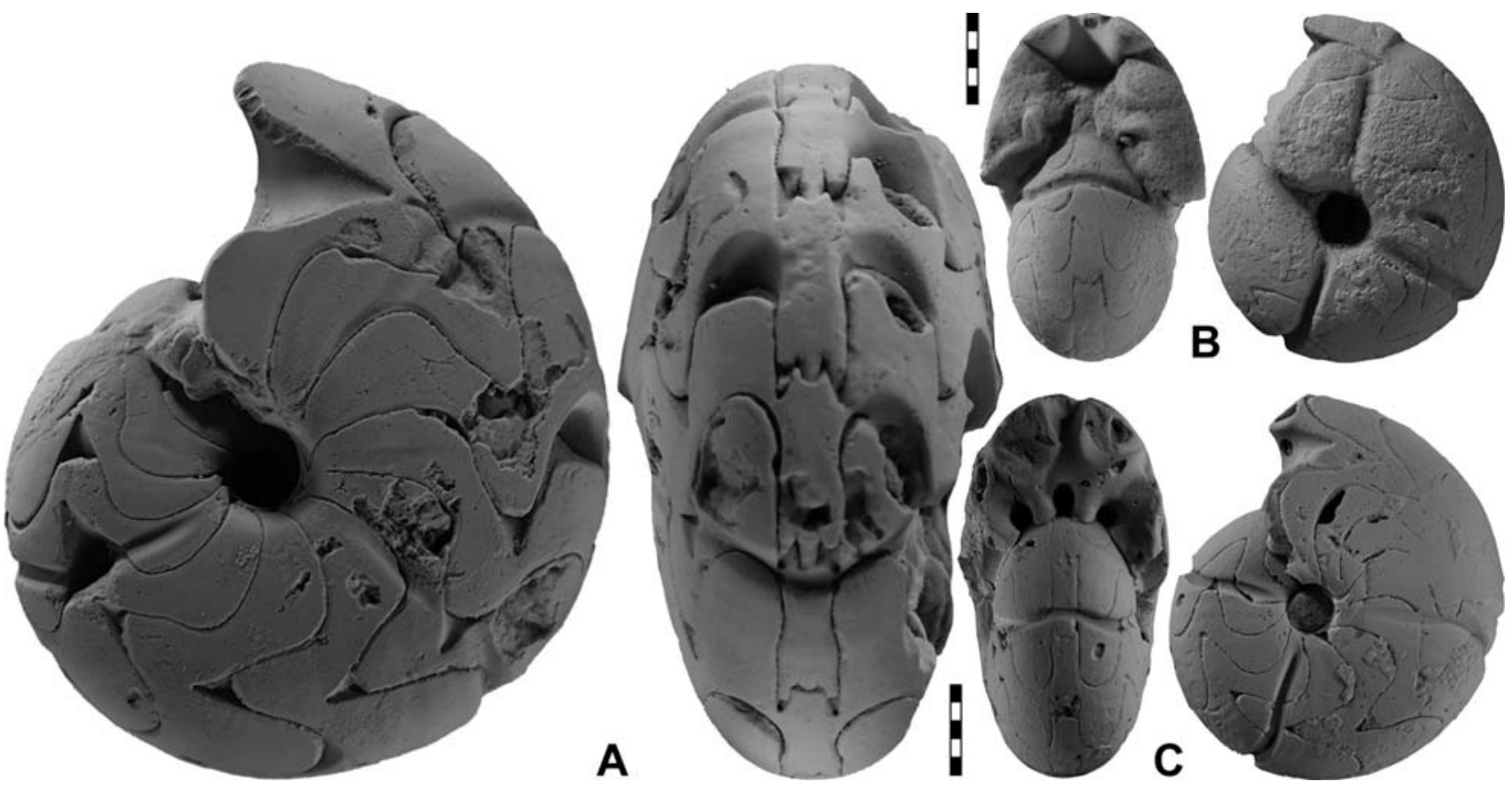

Figure 91. Dzhaprakoceras biconvexum $\quad$ n. sp.; all $\times 2$. A. Holotype MB.C.18737.1 from locality A320-5. B. Paratype MB.C.18737.2 from locality A320-5. C. Paratype MB.C.19014.1 from locality MOU-F. 
Table 132. Suture line proportions (Figs 92D-F) for Dzhaprakoceras biconvexum n. sp.

\begin{tabular}{llllllll}
\hline specimen & at $\mathrm{dm}$ & EL w/d & EL/VLS & EL/AL & MS h & VLS w/h & remarks \\
\hline holotype MB.C.18737.1 & $30.5 \mathrm{~mm}$ & 0.38 & 0.65 & 0.83 & 0.20 & 0.58 & VL saddle and A lobe asymmetric \\
paratype MB.C.18737.2 & $15.4 \mathrm{~mm}$ & 0.49 & 0.86 & 0.91 & 0.23 & 0.57 & A lobe almost symmetric \\
paratype MB.C.18737.6 & $10.1 \mathrm{~mm}$ & 0.51 & 0.71 & 0.78 & 0.23 & 0.73 & \\
\hline
\end{tabular}

Discussion. Dzhaprakoceras biconvexum is mainly characterised by its biconvex steinkern constrictions.

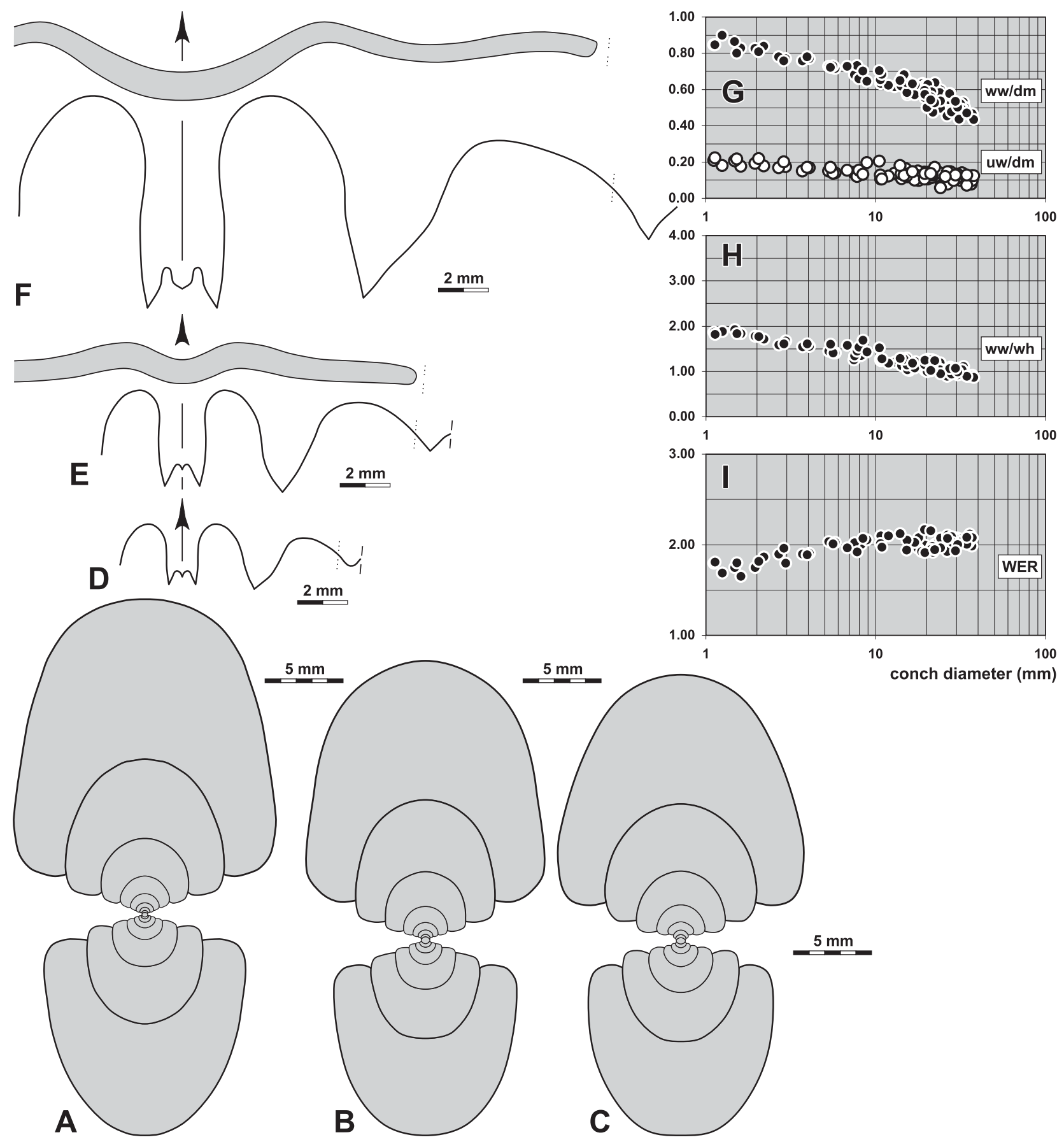

Figure 92. Dzhaprakoceras biconvexum n. sp. from locality A320-5. A. Cross section of paratype MB.C.18737.3; $\times 2.5$. B. Cross section of paratype MB.C.18737.4; $\times 2.5$. C. Cross section of paratype MB.C.18737.5; $\times 2.5$. D. Suture line of paratype MB.C.18737.6, at $10.1 \mathrm{~mm} \mathrm{dm}, 6.5 \mathrm{~mm} w w, 5.4 \mathrm{~mm} \mathrm{wh;} \times 4.0$. E. Suture line and constriction of paratype MB.C.18737.2, at $15.4 \mathrm{~mm} \mathrm{dm}, 10.7 \mathrm{~mm}$ ww, $8.3 \mathrm{~mm}$ wh; $\times 4.0$. F. Suture line and constriction of holotype MB.C.18737.1, at $30.5 \mathrm{~mm} \mathrm{dm}$, $16.6 \mathrm{~mm}$ ww, $15.2 \mathrm{~mm}$ wh; $\times$ 4.0. G-I. Ontogenetic development of the conch width index (ww/dm), umbilical width index (uw/ $\mathrm{dm})$, whorl width index (ww/wh), and whorl expansion rate (WER) of all available specimens. 
Superfamily Goniatitaceae de Haan, 1825

Family Goniatitidae de Haan, 1825

Included subfamilies.

Goniatitinae de Haan, 1825

Arnsbergitinae Korn \& Ebbighausen, 2008

Sygambritinae Korn, 1988

Sudeticeratinae Korn \& Ebbighausen, 2006

Progoniatitinae n. subfam.

Habadraitinae n. subfam.

Antegoniatitinae n. subfam.

Subfamily Progoniatitinae n. subfam.

Subfamily definition. Goniatitidae with a simple conch ontogeny. Early ontogeny up to 4-5 mm conch diameter pachyconic or globular with almost constant ww/dm ratio, the conch becomes continuously more slender in later ontogeny. Early juvenile stage subinvolute or involute. Suture line with strongly diverging external lobe $(\mathrm{EL} \mathrm{w} / \mathrm{d}>0.75 ; \mathrm{EL} / \mathrm{AL}>1.50)$ and usually with asymmetric, acute or subacute ventrolateral saddle.

Included genus.

Progoniatites Korn, Bockwinkel, Ebbighausen \& Klug, 2003

Discussion. The members of the subfamily differ from the subfamilies Goniatitinae and Arnsbergitinae in the simple juvenile conch ontogeny (Korn 1988; Klug et al. 2006; Korn \& Ebbighausen 2008). While the other two subfamilies show a narrowing of the conch at $2-3 \mathrm{~mm} \mathrm{dm}$ followed by an intermediate thickening and a subsequent narrowing, the ww/dm ratio is stable in the Progoniatitinae.

\section{Progoniatites Korn, Bockwinkel, Ebbighausen \& Klug, 2003}

Type species. Progoniatites maghribensis Korn, Bockwinkel, Ebbighausen \& Klug, 2003 (original designation).

Genus definition. Goniatitidae with moderately large conch, reaching approximately $50 \mathrm{~mm}$ in diameter; conch ontogeny two-phased, juvenile stage usually globular and subinvolute, closure of the umbilicus is accompanied by transformation into a pachyconic or discoidal conch. Suture line with V-shaped, mostly narrow or moderately narrow external lobe (EL w/d $=0.50-0.80$; EL/AL $=0.90-1.40)$ and moderately low median saddle (MS $\mathrm{h}=0.35-0.40)$; ventrolateral saddle narrowly rounded or subacute, asymmetric with a dorsadly vergent top.

Included species.

angustilobatus: Glyphioceras angustilobatum Schindewolf, 1926, p. 89: Thuringia.

divisus: Goniatites divisus de Koninck, 1880, p. 117; Belgium.

globulus: Progoniatites globulus n. sp.; Mouydir, Algeria.

karensis: Zhifangoceras karense Kusina, 2000, p. 22; North Urals.

maghribensis: Progoniatites maghribensis Korn, Bockwinkel, Ebbighausen \& Klug, 2003, p. 89; Anti-Atlas, Morocco.

paenacutus: Progoniatites paenacutus n. sp.; Mouydir, Algeria.

pilus: Progoniatites pilus n. sp.; Mouydir, Algeria.

uncus: Progoniatites uncus n. sp.; Mouydir, Algeria.

Discussion. Progoniatites is a strange component in the Tournaisian ammonoid assemblages, the first well-preserved specimens were collected in the North Urals (Kusina 2000; there listed under the genus name Zhifangoceras) and the Anti-Atlas (Korn et al. 2003). The far-reaching morphological relationship to Goniatites (sensu Korn 1988, 1997a, 1997b), which can hardly be explained by convergence, makes Progoniatites a Lazarus taxon (Korn et al. 2005). Despite their close resemblance, Progoniatites and Goniatites do possess some separating characters. The conch ontogeny of Progoniatites is simpler without a distinct widely umbilicate early juvenile stage, as known from Goniatites and the external lobe is wider in Progoniatites.

The most important difference to the co-occurring Antegoniatites n. gen. is the narrower external lobe, the lower median saddle, and the strikingly asymmetric ventrolateral saddle. Habadraites n. gen. differs from Progoniatites in the rounded ventrolateral saddle and the conch ontogeny that shows an increasing aperture height.

Separation of the new species. The four species of Progoniatites from Oued Temertasset can be separated in terms of their conch morphology and their ornament that is, in some cases, visible on the steinkern surface. The bivariate plots for morphometric properties of the four new species display some common features, but also distinguishing characters. A first common feature is the ontogenetic trend in the two-phased ontogeny of the relative conch thickness. In this character, Progoniatites differs from the other representatives of the order Goniatitida (such as the genus Goniatites), which have a three-phased ontogeny. The ontogenetic development of the conch width index differs between the species:

- P. uncus - the CWI is rather constant at 0.80-0.90 until $6 \mathrm{~mm} \mathrm{dm}$, and then continuously decreasing to 0.60 at $30 \mathrm{~mm}$ conch diameter;

- P. pilus - a rather stable CWI is maintained at $0.80-0.90$ up to $9 \mathrm{~mm} \mathrm{dm}$, followed by a decrease to 0.65 at $30 \mathrm{~mm}$ conch diameter;

- P. paenacutus - a more or less continuous decrease of the CWI can be observed, from 0.90 at $2 \mathrm{~mm}$ dm to 0.50 at $20 \mathrm{~mm}$ conch diameter; and

- P. globulus - the conch is thickest at $8 \mathrm{~mm}$ (CWI almost 1.10), and then continuously decreasing to 0.80 at $20 \mathrm{~mm}$ conch diameter. 
A common character of the four species is the early ontogenetic closure of the umbilicus. They possess an opened umbilicus (uw/dm $=0.20-$ 0.40 ) in the initial stage, and the reduction of the umbilical width index to a value of 0.10 happens at conch diameters between 3 and 5 mm. In the ontogenetic modification of the aperture height, there are two different modes to be recognised:

- P. globulus has an almost stable low whorl expansion rate (WER around 1.50) throughout ontogeny, but

- P. uncus, P. pilus, and P. paenacutus show ontogenetic variations. These include an increase of the WER in juvenile stages between 4 and $8 \mathrm{~mm}$ conch diameter, where a maximum value of 2.00 can be reached. In the adult stage, a decrease to a value of $1.50-1.60$ ( $P$. uncus and P. pilus) or 1.80 (P. paenacutus) can be observed.

The ornament, partly visible on the internal mould, reveals further criteria to separate between the species:

- P. pilus and P. paenacutus possess an ornament with weak transverse ribs on the venter, but

- P. uncus lacks ribs; a fine spiral ornament is particularly developed on the flanks near the umbilicus.

The suture lines of the four Algerian species of Progoniatites display differences, which help to separate them. A major specific character is the width of the external lobe, i.e., the ratio of width and depth.

Discussion. P. maghribensis Korn et al., 2003 has a thickly pachyconic, involute conch at $15 \mathrm{~mm} \mathrm{dm}$ (ww/ $\mathrm{dm}=0.84 ; \mathrm{uw} / \mathrm{dm}=0.13$ ) and thus resembles P. pilus. P. maghribensis lacks the riblets present in P. pilus and has a narrower external lobe.

P. karensis (Kusina, 2000) has a conch shape $(\mathrm{ww} / \mathrm{dm}=0.56, \mathrm{uw} / \mathrm{dm}=0.11$ at $34 \mathrm{~mm} \mathrm{dm})$ similar to P. uncus, but possesses weak riblets that are absent in P. uncus.

P. divisus (de Koninck, 1880) is based on poorly preserved specimens, which only allow for the recognition of a thickly pachyconic, involute conch that is ornamented with weak riblets extending across the venter. P. angustilobatus (Schindewolf, 1926) is based on distorted specimens, which do not allow for the description of all conch characters. The adventive lobe is shown to be deeper than the external lobe, but this may be caused by deformation.

Remarks. Progoniatites was proposed by Korn et al. $(2003,2005)$ for early Late Tournaisian ammonoids with a suture line that closely resembles the Late Viséan genus Goniatites. At that time, Progoniatites was only represented by a few species of which only the type species was well known. The discovery of four additional species in the Mouydir of Algeria allows now for a revision of the genus based on this new rich material.

Stratigraphic occurrence. Those species of the genus that were found in stratigraphically well-dated successions, i.e., the records from North Africa come from horizons with early Late Tournaisian ammonoid assemblages with Pericyclus, Temertassetia, Imitoceras, Muensteroceras, Eurites, Jerania, etc. The other occurrences, for instance in the Rußschiefer of Zadelsdorf, are not dated as accurately, but they do not contradict the assignment to an early Late Tournaisian age.

\section{Progoniatites uncus n. sp.}

Figures 93, 94

Derivation of name. From Latin uncus = hook, because of the top of the ventrolateral saddle.

Holotype. Specimen MB.C.18902.1, illustrated in Figure 93A.

Type locality and horizon. Oued Temertasset, locality and sample MOU-D2 (Mouydir, South Algeria); upper Pericyclus-Progoniatites Assemblage. Material. 143 specimens, conch diameter up to $35 \mathrm{~mm}$.

Diagnosis. Progoniatites with a globular conch in the juvenile stage (up to $7 \mathrm{~mm} \mathrm{dm}$ ), thereafter becoming more slender and being thinly pachyconic at $30 \mathrm{~mm} \mathrm{dm}$; conch subinvolute in early juveniles and involute above $3 \mathrm{~mm} \mathrm{dm}$; umbilical margin rounded; aperture high at $8 \mathrm{~mm}$ $\mathrm{dm}$ and moderate in smaller and larger stages. Steinkern with delicate spiral lines around the umbilicus, without riblets; convex constrictions with wide and moderately deep ventral sinus. Suture line with narrow external lobe that varies in the degree of divergence; median saddle moderately low; ventrolateral saddle subacute; adventive lobe deep, asymmetric with strongly curved ventral flank.

Table 133. Conch ontogeny (Figs 94A, F-H) of Progoniatites uncus n. sp.

\begin{tabular}{|c|c|c|c|}
\hline $\mathrm{dm}$ & conch shape & whorl cross section shape & aperture \\
\hline $2 \mathrm{~mm}$ & $\begin{array}{l}\text { thinly globular; subinvolute } \\
\text { (ww/dm } \sim 0.86 ; \text { uw/dm } \sim 0.25 \text { ) }\end{array}$ & $\begin{array}{l}\text { moderately depressed; very strongly embracing } \\
\text { (ww/wh } \sim 2.00 ; \text { IZR } \sim 0.48 \text { ) }\end{array}$ & $\begin{array}{l}\text { moderate } \\
(\text { WER } \sim 1.75)\end{array}$ \\
\hline $8 \mathrm{~mm}$ & $\begin{array}{l}\text { thickly pachyconic; involute } \\
(\mathrm{ww} / \mathrm{dm}=0.74-0.82 ; \mathrm{uw} / \mathrm{dm}=0.05-0.10)\end{array}$ & $\begin{array}{l}\text { weakly to moderately depressed; very strongly } \\
\text { embracing ( } w w / w h=1.35-1.60 ; \mathrm{IZR}=0.45-0.50 \text { ) }\end{array}$ & $\begin{array}{l}\text { high } \\
\text { (WER 2.05) }\end{array}$ \\
\hline $20 \mathrm{~mm}$ & $\begin{array}{l}\text { thinly pachyconic; involute } \\
(\mathrm{ww} / \mathrm{dm}=0.63-0.72 ; \mathrm{uw} / \mathrm{dm}=0.05-0.12)\end{array}$ & $\begin{array}{l}\text { weakly depressed; very strongly embracing } \\
(\mathrm{ww} / \mathrm{wh}=1.15-1.50 ; \mathrm{IZR}=0.45-0.50)\end{array}$ & $\begin{array}{l}\text { low to moderate } \\
(\mathrm{WER}=1.65-1.85)\end{array}$ \\
\hline $30 \mathrm{~mm}$ & $\begin{array}{l}\text { thinly pachyconic; involute } \\
(\mathrm{ww} / \mathrm{dm}=0.60-0.68 ; \mathrm{w} / \mathrm{dm}=0.08-0.12)\end{array}$ & $\begin{array}{l}\text { weakly depressed; very strongly embracing } \\
\text { (ww/wh }=1.20-1.45 ; \text { IZR }=0.45-0.50)\end{array}$ & $\begin{array}{l}\text { low } \\
(\text { WER } \sim 1.65)\end{array}$ \\
\hline
\end{tabular}


Table 134. Conch dimensions (in $\mathrm{mm}$ ) and proportions for reference specimens of Progoniatites uncus $\mathrm{n}$. sp.

\begin{tabular}{lccccccccccc}
\hline & $\mathrm{dm}$ & ww & wh & uw & ah & ww/dm & ww/wh & uw/dm & WER & IZR \\
\hline holotype MB.C.18902.1 & 28.5 & 18.2 & 14.8 & 2.4 & 6.3 & 0.64 & 1.23 & 0.09 & 1.64 & 0.58 \\
paratype MB.C.18902.2 & 26.7 & 16.8 & 13.3 & 2.8 & 6.2 & 0.63 & 1.26 & 0.10 & 1.70 & 0.53 \\
paratype MB.C.18902.3 & 24.0 & 15.3 & 10.5 & 2.6 & 5.9 & 0.64 & 1.47 & 0.11 & 1.76 & 0.44 \\
paratype MB.C.18876.1 & 19.7 & 13.4 & 9.6 & 2.2 & 4.9 & 0.68 & 1.39 & 0.11 & 1.76 & 0.50 \\
paratype MB.C.18902.4 & 15.6 & 10.1 & 7.6 & 1.2 & - & 0.65 & 1.33 & 0.08 & - & - \\
paratype MB.C.19059.1 & 14.4 & 10.8 & 7.9 & 1.5 & 3.7 & 0.75 & 1.36 & 0.10 & 1.81 & 0.54 \\
paratype MB.C.18902.5 & 10.6 & 7.8 & 5.7 & 0.8 & 2.8 & 0.74 & 1.39 & 0.08 & 1.85 & 0.51 \\
\hline
\end{tabular}

Table 135. Suture line proportions (Figs 94B-E) for Progoniatites uncus n. sp.

\begin{tabular}{llllllll}
\hline specimen & at dm & EL w/d & EL/VLS & EL/AL & MS h & VLS w/h & remarks \\
\hline holotype MB.C.18902.1 & $22.9 \mathrm{~mm}$ & 0.55 & 1.54 & 1.04 & 0.42 & 0.36 & E lobe weakly diverging \\
paratype MB.C.18902.3 & $21.8 \mathrm{~mm}$ & 0.60 & 1.25 & 1.13 & 0.39 & 0.48 & E lobe strongly diverging \\
paratype MB.C.18902.4 & $15.5 \mathrm{~mm}$ & 0.56 & 1.07 & 1.36 & 0.46 & 0.52 & VL saddle narrowly rounded \\
paratype MB.C.18902.5 & $10.6 \mathrm{~mm}$ & 0.65 & 1.66 & 0.86 & 0.35 & 0.39 & VL saddle narrowly rounded \\
\hline
\end{tabular}

Remarks. Progoniatites uncus possesses some variability in the suture line, as shown in the comparison of holotype MB.C.18902.1 and paratype MB.C.18902.3 (Figs 94D, E). The external lobe particularly differs in its shape, being strongly divergent with a very narrow base in paratype MB.C.18902.3.

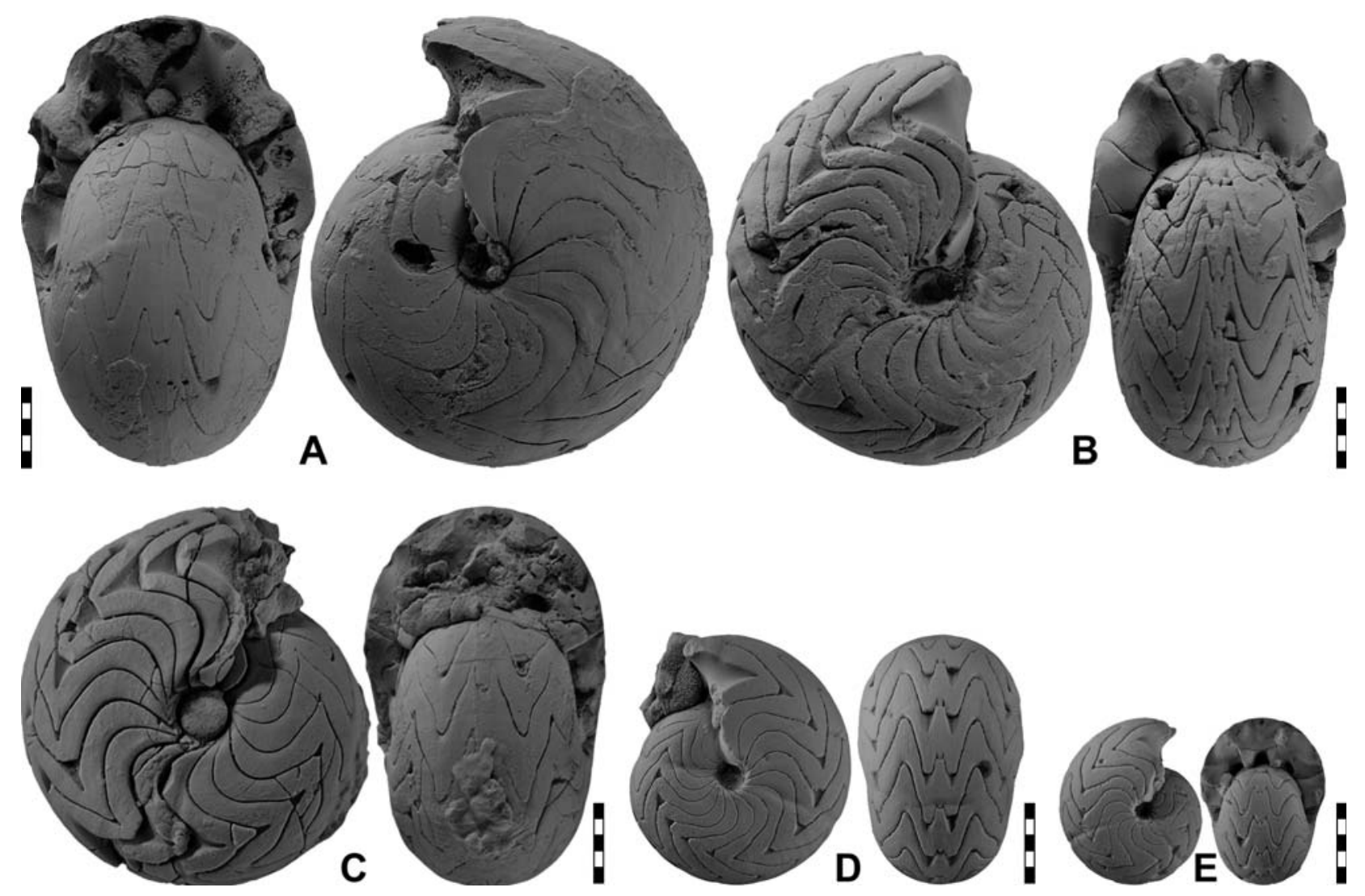

Figure 93. Progoniatites uncus n. sp. from locality MOU-D2; all ×2. A. Holotype MB.C.18902.1. B. Paratype MB.C.18902.2. C. Paratype MB.C.18902.3. D. Paratype MB.C.18902.4. E. Paratype MB.C.18902.5. 


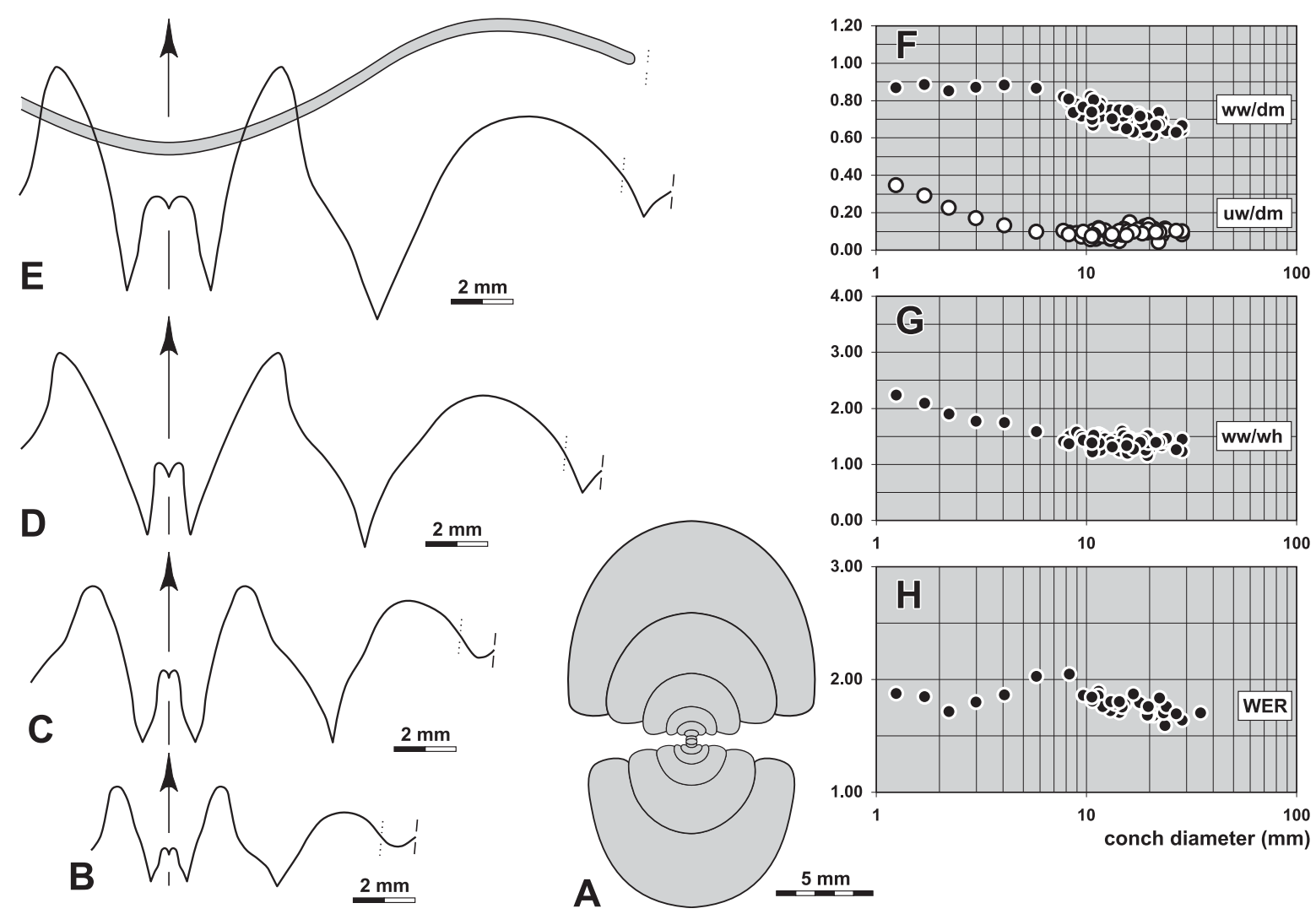

Figure 94. Progoniatites uncus n. sp. A. Cross section of paratype MB.C.18953.1 from locality MOU-E07; $\times 2.5$. B. Suture line of paratype MB.C.18902.5 from locality MOU-D2, at $10.8 \mathrm{~mm} \mathrm{dm}, 7.8 \mathrm{~mm}$ ww, $5.6 \mathrm{~mm}$ wh; $\times 5.0$. C. Suture line of paratype MB.C.18902.4 from locality MOU-D2, at $15.5 \mathrm{~mm} \mathrm{dm}, 10.1 \mathrm{~mm}$ ww, $7.5 \mathrm{~mm}$ wh; $\times 5.0$. D. Suture line of paratype MB.C.18902.3 from locality MOUD2, at $21.8 \mathrm{~mm} \mathrm{dm}, 14.3 \mathrm{~mm}$ ww, $10.0 \mathrm{~mm}$ wh; $\times 5.0$. E. Suture line and steinkern constriction of holotype MB.C.18902.1 from locality MOU-D2, at $22.9 \mathrm{~mm} \mathrm{dm}, 16.1 \mathrm{~mm}$ ww, $12.1 \mathrm{~mm}$ wh; $\times 5.0 . \mathbf{F}-\mathbf{H}$. Ontogenetic development of the conch width index (ww/dm), umbilical width index (uw/dm), whorl width index (ww/wh), and whorl expansion rate (WER) of all available specimens.

\section{Progoniatites pilus n. sp.}

Figures 95, 96

Derivation of name. From Latin pilus = ball, because of the stout conch.

Holotype. Specimen MB.C.18954.1, illustrated in Figure 95A.

Type locality and horizon. Oued Temertasset, locality and sample MOU-E07 (Mouydir, South Algeria); upper Pericyclus-Progoniatites Assemblage.

Material. 47 specimens, conch diameter up to $31 \mathrm{~mm}$.

Diagnosis. Progoniatites with thickly pachyconic or globular conch in the juvenile and preadult stage (up to $16 \mathrm{~mm} \mathrm{dm}$ ), thereafter becoming more slender and being thinly pachyconic at $30 \mathrm{~mm} \mathrm{dm}$; conch subinvolute in early juveniles and involute above $2 \mathrm{~mm}$ dm; umbilical margin subangular; aperture high at $5 \mathrm{~mm} \mathrm{dm}$ and low to moderate in smaller and larger stages. Steinkern with gentle constrictions, which extend in convex course across the flank and form a wide and deep ventral sinus; venter with shallow, rounded riblets. Suture line with narrow to moderately narrow external lobe; median saddle low or moderately low; ventrolateral saddle very asymmetric and subacute; adventive lobe strongly asymmetric with strongly curved ventral flank.

Table 136. Conch ontogeny (Figs 96A, E-G) of Progoniatites pilus n. sp.

\begin{tabular}{|c|c|c|c|}
\hline $\mathrm{dm}$ & conch shape & whorl cross section shape & aperture \\
\hline $2 \mathrm{~mm}$ & $\begin{array}{l}\text { thinly globular; involute } \\
\text { (ww/dm } \sim 0.86 ; \text { uw/dm } \sim 0.14 \text { ) }\end{array}$ & $\begin{array}{l}\text { moderately depressed; very strongly embracing } \\
\text { (ww/wh } \sim 1.75 ; \text { IZR } \sim 0.50 \text { ) }\end{array}$ & $\begin{array}{l}\text { moderate } \\
(\text { WER } \sim 1.75)\end{array}$ \\
\hline $8 \mathrm{~mm}$ & $\begin{array}{l}\text { thickly pachyconic to thinly globular; involute } \\
(\mathrm{ww} / \mathrm{dm}=0.80-0.90 ; \mathrm{uw} / \mathrm{dm}=0.07-0.10)\end{array}$ & $\begin{array}{l}\text { weakly to moderately depressed; very strongly } \\
\text { embracing }(w w / w h=1.40-1.60 ; I Z R=0.52-0.58)\end{array}$ & $\begin{array}{l}\text { low to moderate } \\
(\text { WER }=1.65-1.80)\end{array}$ \\
\hline $20 \mathrm{~mm}$ & $\begin{array}{l}\text { thinly to thickly pachyconic; involute } \\
\text { (ww/dm }=0.68-0.80 ; \mathrm{uw} / \mathrm{dm}=0.08-0.13 \text { ) }\end{array}$ & $\begin{array}{l}\text { weakly to moderately depressed; very strongly } \\
\text { embracing ( } w w / w h=1.40-1.70 ; \text { IZR }=0.54-0.60 \text { ) }\end{array}$ & $\begin{array}{l}\text { low } \\
(\text { WER }=1.55-1.70)\end{array}$ \\
\hline $30 \mathrm{~mm}$ & $\begin{array}{l}\text { thinly pachyconic; involute } \\
\text { (ww/dm } \sim 0.65 ; \text { uw/dm } \sim 0.10 \text { ) }\end{array}$ & $\begin{array}{l}\text { weakly depressed; very strongly embracing } \\
\text { (ww/wh } \sim 1.30 ; \text { IZR } \sim 0.62 \text { ) }\end{array}$ & $\begin{array}{l}\text { low } \\
(\text { WER } \sim 1.55)\end{array}$ \\
\hline
\end{tabular}


Table 137. Conch dimensions (in $\mathrm{mm}$ ) and proportions for reference specimens of Progoniatites pilus $\mathrm{n}$. sp.

\begin{tabular}{lcccccccccc}
\hline & $\mathrm{dm}$ & ww & wh & uw & ah & ww/dm & ww/wh & uw/dm & WER & IZR \\
\hline holotype MB.C.18954.1 & 30.7 & 20.3 & 15.4 & 2.6 & 6.0 & 0.66 & 1.32 & 0.09 & 1.55 & 0.61 \\
paratype MB.C.18903.1 & 22.8 & 14.8 & 12.0 & 1.8 & 5.5 & 0.65 & 1.23 & 0.08 & 1.74 & 0.54 \\
paratype MB.C.18964 & 20.6 & 14.1 & 9.7 & 2.2 & 4.4 & 0.69 & 1.45 & 0.11 & 1.63 & 0.54 \\
paratype MB.C.18777 & 15.4 & 11.9 & 7.7 & 1.4 & 3.5 & 0.77 & 1.53 & 0.09 & 1.66 & 0.55 \\
paratype MB.C.18903.3 & 11.9 & 9.1 & 6.3 & 1.2 & 2.7 & 0.77 & 1.44 & 0.10 & 1.67 & 0.58 \\
paratype MB.C.18903.2 & 10.6 & 8.3 & 5.8 & 0.6 & 2.4 & 0.78 & 1.44 & 0.06 & 1.68 & 0.58 \\
\hline
\end{tabular}

Table 138. Suture line proportions (Figs 96B-D) for Progoniatites pilus n. sp.

\begin{tabular}{llllllll}
\hline specimen & at dm & EL w/d & EL/VLS & EL/AL & MS h & VLS w/h & remarks \\
\hline holotype MB.C.18954.1 & $27.5 \mathrm{~mm}$ & 0.80 & 1.63 & 0.99 & 0.34 & 0.49 & VL saddle subacute \\
paratype MB.C.18750.1 & $20.8 \mathrm{~mm}$ & 0.67 & 1.94 & 1.13 & 0.38 & 0.35 & E lobe with almost straight flanks \\
paratype MB.C.18903.2 & $10.2 \mathrm{~mm}$ & 0.55 & 1.26 & 0.95 & 0.32 & 0.43 & VL saddle narrowly rounded \\
\hline
\end{tabular}
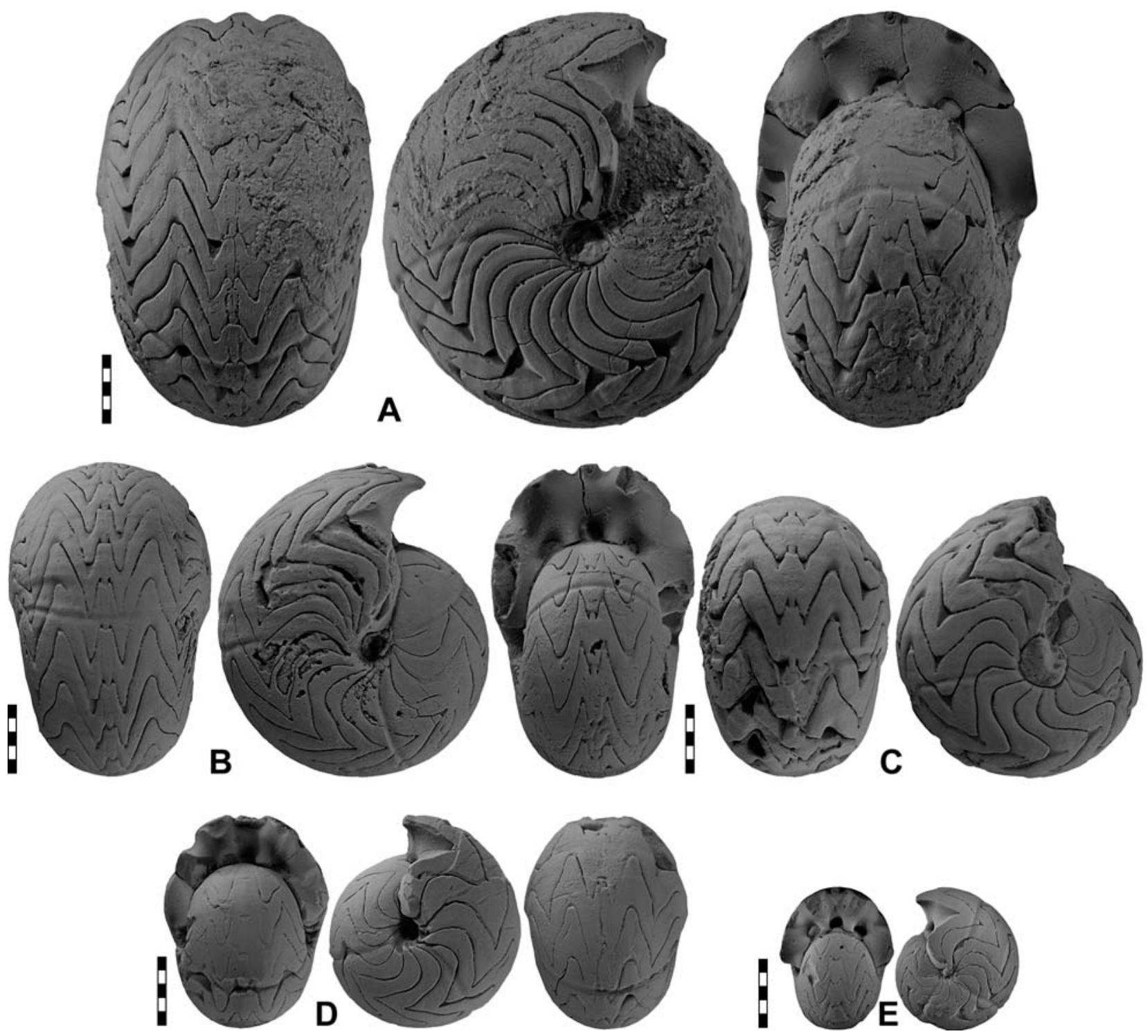

Figure 95. Progoniatites pilus n. sp.; all $\times 2$. A. Holotype MB.C.18954.1 from locality MOU-E07. B. Paratype MB.C.18903.1 from locality MOU-D2. C. Paratype MB.C.18964 from locality MOU-E08. D. Paratype MB.C.18777 from locality MOU-D1. E. Paratype MB.C.18903.2 from locality MOU-D2. 
Discussion. Suture lines of Progoniatites pilus show some variability; they differ in the shape of the external lobe and also in the width of the adventive lobe (Figs 96B-D). Common features, however are the rather wide and strikingly asymmetric adventive lobe and the shape of the narrowly rounded or subacute ventrolateral saddle.
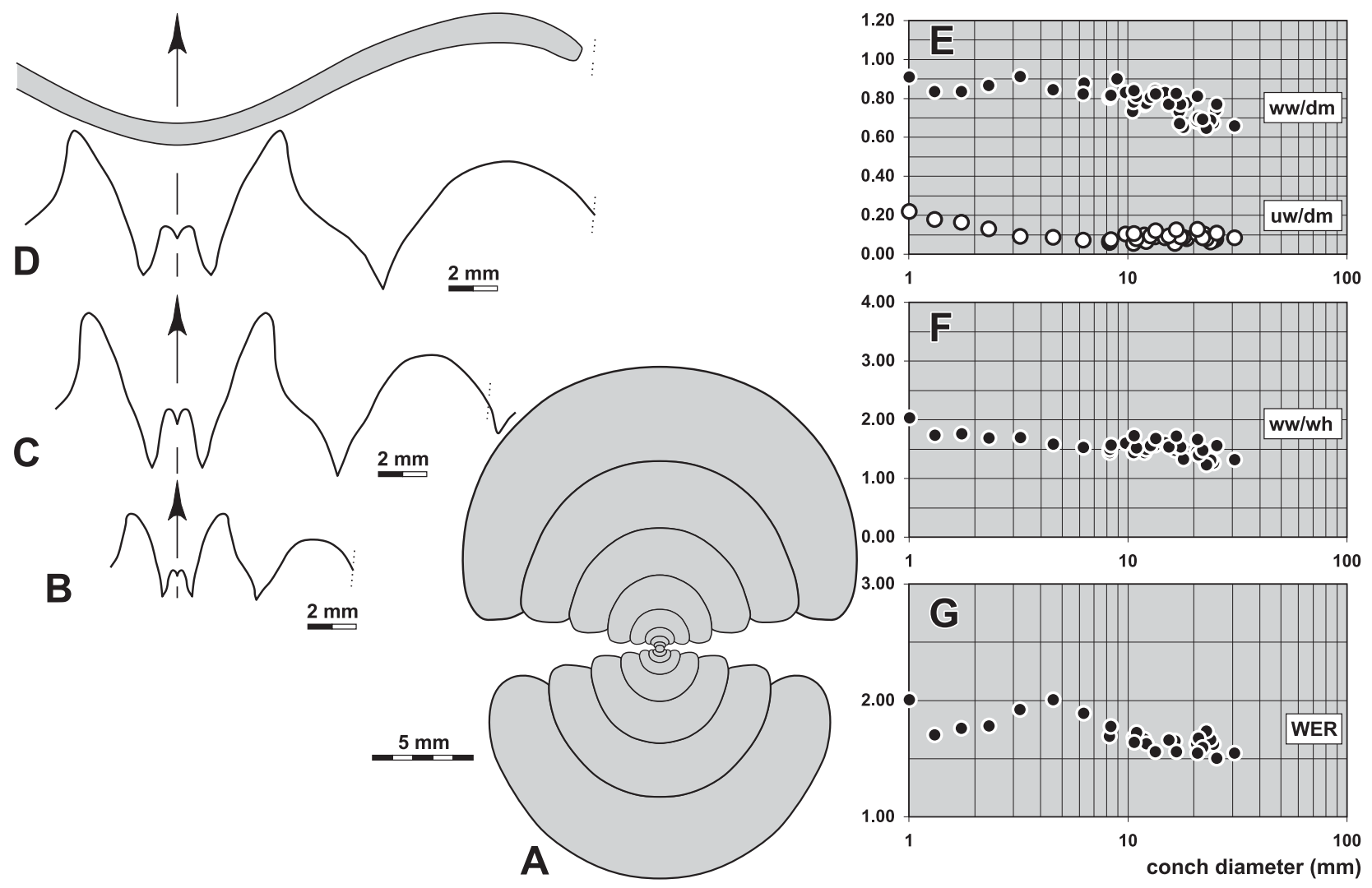

Figure 96. Progoniatites pilus n. sp. A. Cross section of paratype MB.C.18970 from locality MOU-E09; $\times 2.5$. B. Suture line of paratype MB.C.18903.2 from locality MOU-D2, at $10.2 \mathrm{~mm} \mathrm{dm}, 7.4 \mathrm{~mm}$ ww, $5.9 \mathrm{~mm}$ wh; $\times 4.0$. C. Suture line of paratype MB.C. 18750.1 from locality A321, at $20.8 \mathrm{~mm} \mathrm{dm}, 14.5 \mathrm{~mm}$ ww, $10.9 \mathrm{~mm}$ wh; $\times 4.0$. D. Suture line and steinkern constriction of holotype MB.C.18954.1 from locality MOU-E07, at $27.5 \mathrm{~mm} \mathrm{dm}, 20.5 \mathrm{~mm}$ ww, $14.2 \mathrm{~mm}$ wh; $\times 4.0$. E-G. Ontogenetic development of the conch width index (ww/dm), umbilical width index (uw/dm), whorl width index (ww/wh), and whorl expansion rate (WER) of all available specimens.

\section{Progoniatites paenacutus n. sp.}

Figures 97, 98

Derivation of name. From Latin paenus $=$ nearly and acutus $=$ sharp, because of the shape of the ventrolateral saddle.

Holotype. Specimen MB.C.18904.1, illustrated in Figure 97A.

Type locality and horizon. Oued Temertasset, sample MOU-D2 (Mouydir, South Algeria); upper Pericyclus-Progoniatites Assemblage.

Material. 18 specimens, conch diameter up to $22 \mathrm{~mm}$.

Diagnosis. Progoniatites with thickly pachyconic or globular conch in the juvenile and preadult stage (up to $10 \mathrm{~mm} \mathrm{dm}$ ), thereafter becoming more slender and being thickly discoidal at $20 \mathrm{~mm} \mathrm{dm}$; conch subinvolute in early juveniles and involute above $3 \mathrm{~mm} \mathrm{dm}$; umbilical margin narrowly rounded; aperture high at $8 \mathrm{~mm} \mathrm{dm}$ and moderate in smaller and larger stages. Steinkern with gentle constrictions, which extend in convex course, venter with shallow, rounded riblets. Suture line with narrow V-shaped external lobe; median saddle moderately low; ventrolateral saddle subacute, slightly asymmetric; adventive lobe asymmetric with curved flanks.

Table 139. Conch ontogeny (Figs 98A, D-F) of Progoniatites paenacutus n. sp.

\begin{tabular}{llll}
\hline $\mathrm{dm}$ & conch shape & whorl cross section shape & aperture \\
\hline $2 \mathrm{~mm}$ & thinly globular; subinvolute & moderately depressed; very strongly embracing & moderate \\
& $($ ww/dm $\sim 0.86 ;$ uw/dm $\sim 0.25)$ & (ww/wh $\sim 1.90 ;$ IZR $\sim 0.45)$ & $($ WER $\sim 1.75)$ \\
$8 \mathrm{~mm}$ & thickly pachyconic; involute & weakly depressed; very strongly embracing & high \\
& $($ ww/dm $\sim 0.75 ;$ uw/dm $\sim 0.08)$ & $($ ww/wh $\sim 1.40 ;$ IZR $\sim 0.47)$ & $($ WER $\sim 2.00)$ \\
$20 \mathrm{~mm}$ & thickly discoidal; involute & weakly depressed; very strongly embracing & moderate \\
& $($ ww/dm $\sim 0.55 ;$ uw/dm $\sim 0.06)$ & $($ ww/wh $=1.00-1.10 ;$ IZR $=0.45-0.55)$ & $($ WER $=1.75-1.85)$ \\
\hline
\end{tabular}


Table 140. Conch dimensions (in $\mathrm{mm}$ ) and proportions for reference specimens of Progoniatites paenacutus $\mathrm{n}$. sp.

\begin{tabular}{lccccccccccc}
\hline & $\mathrm{dm}$ & ww & wh & uw & ah & ww/dm & ww/wh & uw/dm & WER & IZR \\
\hline holotype MB.C.18904.1 & 18.5 & 11.0 & 9.6 & 1.9 & 4.6 & 0.60 & 1.15 & 0.10 & 1.78 & 0.52 \\
paratype MB.C.18965.1 & 17.6 & 11.0 & 8.7 & 1.8 & 4.6 & 0.62 & 1.27 & 0.10 & 1.83 & 0.47 \\
paratype MB.C.18904.2 & 13.6 & 9.1 & 7.6 & 1.1 & 3.4 & 0.67 & 1.20 & 0.08 & 1.79 & 0.55 \\
\hline
\end{tabular}

Table 141. Suture line proportions (Figs 98B, C) for Progoniatites paenacutus n. sp.

\begin{tabular}{llllllll}
\hline specimen & at dm & EL w/d & EL/VLS & EL/AL & MS h & VLS w/h & remarks \\
\hline holotype MB.C.18904.1 & $18.4 \mathrm{~mm}$ & 0.56 & 1.34 & 0.93 & 0.40 & 0.42 & flanks of A lobe strongly curved \\
paratype MB.C.18904.2 & $13.9 \mathrm{~mm}$ & 0.54 & 1.11 & 0.99 & 0.33 & 0.49 & \\
\hline
\end{tabular}

Discussion. P. paenacutus is the most slender of the African species of Progoniatites and thus rather easy to separate from the others. Closest to it in conch shape is P. uncus, but that species shows spiral ornament on the steinkern and lacks riblets.
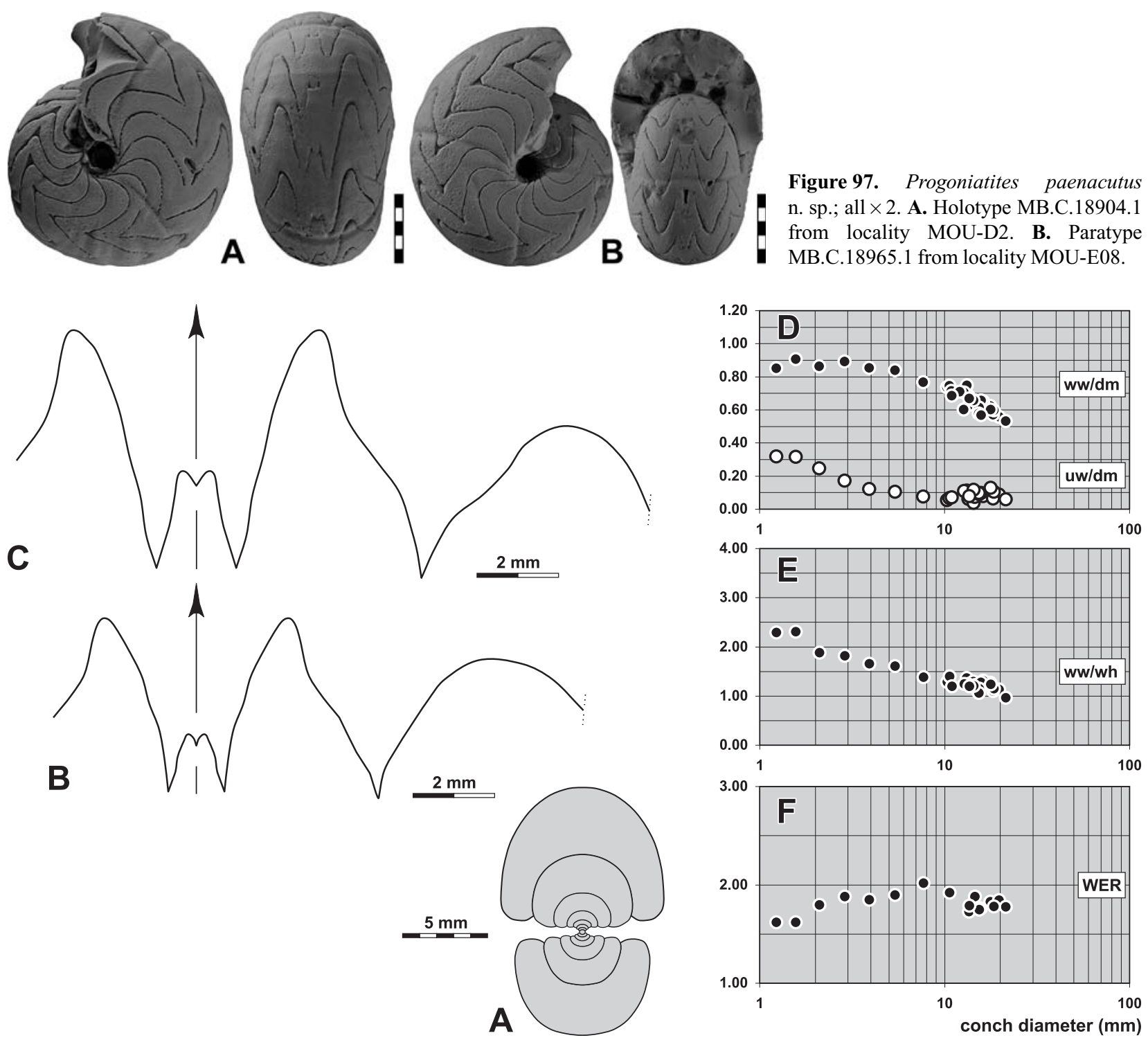

Figure 98. Progoniatites paenacutus n. sp. A. Cross section of paratype MB.C.18955 from locality MOU-E07; $\times 2.5$. B. Suture line of paratype MB.C.18904.2 from locality MOU-D2, at $13.9 \mathrm{~mm} \mathrm{dm}, 9.0 \mathrm{~mm} w w, 7.5 \mathrm{~mm} w \mathrm{wh} \times 6.0$. C. Suture line of holotype MB.C.18904.1 from locality MOU-D2, at $18.4 \mathrm{~mm} \mathrm{dm}, 11.0 \mathrm{~mm}$ ww, $9.5 \mathrm{~mm}$ wh; $\times 6.0$. D-F. Ontogenetic development of the conch width index (ww/dm), umbilical width index (uw/dm), whorl width index (ww/wh), and whorl expansion rate (WER) of all available specimens. 


\section{Progoniatites globulus n. sp.}

Figures 99, 100

Derivation of name. From Latin globulus $=$ little globe, because of the conch shape.

Holotype. Specimen MB.C.18879.1, illustrated in Figure 99A.

Type locality and horizon. Oued Temertasset, locality and sample MOU-D1 (Mouydir, South Algeria); upper Pericyclus-Progoniatites Assemblage.

Material. 12 specimens, conch diameter up to $20 \mathrm{~mm}$.

Diagnosis. Progoniatites with globular conch in the juvenile and preadult stage (up to $12 \mathrm{~mm} \mathrm{dm}$ ), thereafter becoming more slender and being thickly pachyconic at $20 \mathrm{~mm} \mathrm{dm}$; conch subinvolute in early juveniles and involute above $2 \mathrm{~mm}$ dm; umbilical margin rounded; aperture low throughout ontogeny. Steinkern with gentle constrictions, which extend in convex course, without riblets. Suture line possesses elements with almost linear flanks; external lobe narrow, median saddle moderately low; ventrolateral saddle asymmetric and subacute; adventive lobe Vshaped, deep.

Table 142. Conch ontogeny (Figs 100A, D-F) of Progoniatites globulus n. sp.

\begin{tabular}{|c|c|c|c|}
\hline$d m$ & conch shape & whorl cross section shape & aperture \\
\hline $2 \mathrm{~mm}$ & $\begin{array}{l}\text { thickly globular; subinvolute } \\
\text { (ww/dm } \sim 1.05 ; \text { uw/dm } \sim 0.16 \text { ) }\end{array}$ & $\begin{array}{l}\text { strongly depressed; very strongly embracing } \\
\text { (ww/wh } \sim 2.25 ; \mathrm{IZR} \sim 0.60 \text { ) }\end{array}$ & $\begin{array}{l}\text { low } \\
(\text { WER } \sim 1.50)\end{array}$ \\
\hline $8 \mathrm{~mm}$ & $\begin{array}{l}\text { thinly to thickly globular; involute } \\
(\mathrm{ww} / \mathrm{dm}=0.90-1.00 ; \mathrm{uw} / \mathrm{dm}=0.08-0.12)\end{array}$ & $\begin{array}{l}\text { moderately depressed; very strongly embracing } \\
(\mathrm{ww} / \mathrm{wh}=1.80-2.00 ; \mathrm{IZR} \sim 0.60)\end{array}$ & $\begin{array}{l}\text { low } \\
(\text { WER } \sim 1.55)\end{array}$ \\
\hline $20 \mathrm{~mm}$ & $\begin{array}{l}\text { thickly pachyconic; involute } \\
(\mathrm{ww} / \mathrm{dm} \sim 0.78 ; \mathrm{uw} / \mathrm{dm} \sim 0.10)\end{array}$ & $\begin{array}{l}\text { moderately depressed; very strongly embracing } \\
\text { (ww/wh } \sim 1.60 ; \text { IZR } \sim 0.60 \text { ) }\end{array}$ & $\begin{array}{l}\text { low } \\
(\text { WER } \sim 1.60)\end{array}$ \\
\hline
\end{tabular}

Table 143. Conch dimensions (in $\mathrm{mm}$ ) and proportions for reference specimens of Progoniatites globulus $\mathrm{n}$. $\mathrm{sp}$.

\begin{tabular}{lccccccccccc}
\hline & $\mathrm{dm}$ & ww & wh & uw & ah & ww/dm & ww/wh & uw/dm & WER & IZR \\
\hline holotype MB.C.18879.1 & 19.9 & 15.6 & 9.7 & 1.9 & 4.1 & 0.78 & 1.60 & 0.10 & 1.59 & 0.58 \\
paratype MB.C.19029.2 & 15.0 & 12.4 & 7.8 & 2.1 & 3.0 & 0.83 & 1.59 & 0.14 & 1.57 & 0.61 \\
paratype MB.C.18775.1 & 10.5 & 9.9 & 5.4 & 1.3 & 1.9 & 0.94 & 1.83 & 0.12 & 1.49 & 0.65 \\
paratype MB.C.19029.1 & 10.4 & 9.2 & 5.0 & 1.2 & 2.0 & 0.89 & 1.87 & 0.11 & 1.54 & 0.59 \\
\hline
\end{tabular}

Table 144. Suture line proportions (Figs 100B, C) for Progoniatites globulus n. sp.

\begin{tabular}{llllllll}
\hline specimen & at dm & EL w/d & EL/NLS & EL/AL & MS h & VLS w/h & remarks \\
\hline holotype MB.C.18879.1 & $18.8 \mathrm{~mm}$ & 0.53 & 1.53 & 1.26 & 0.37 & 0.34 & VL saddle subacute, dorsally inclined \\
paratype MB.C.18775.1 & $10.3 \mathrm{~mm}$ & 0.50 & 1.15 & 1.04 & 0.31 & 0.43 & VL saddle narrowly rounded \\
\hline
\end{tabular}

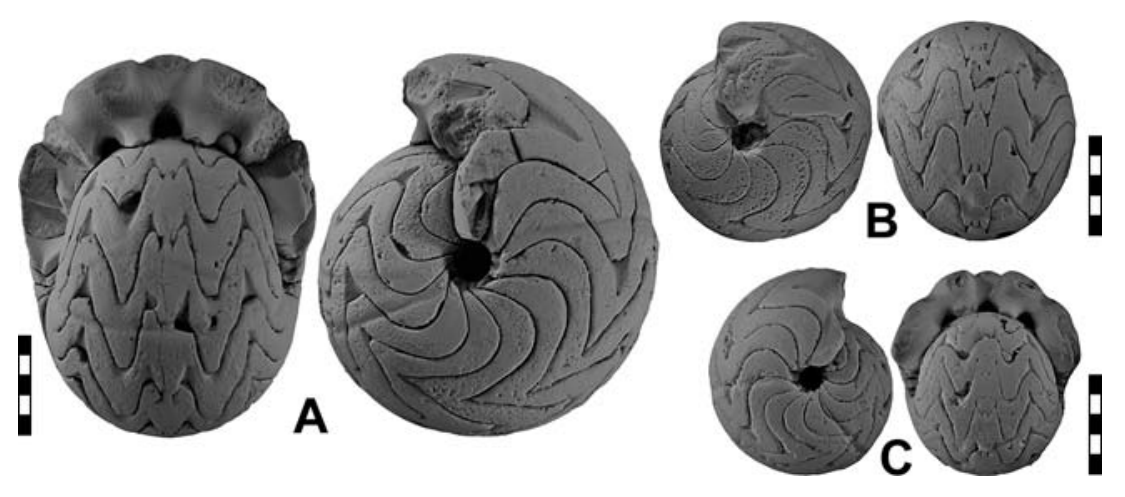

Figure 99. Progoniatites globulus n. sp.; all $\times 2$. A. Holotype MB.C.18879.1 from locality MOU-D1. B. Paratype MB.C.18775.1 from locality MOU-A. C. Paratype MB.C.19029.1 from locality MOU-V. 

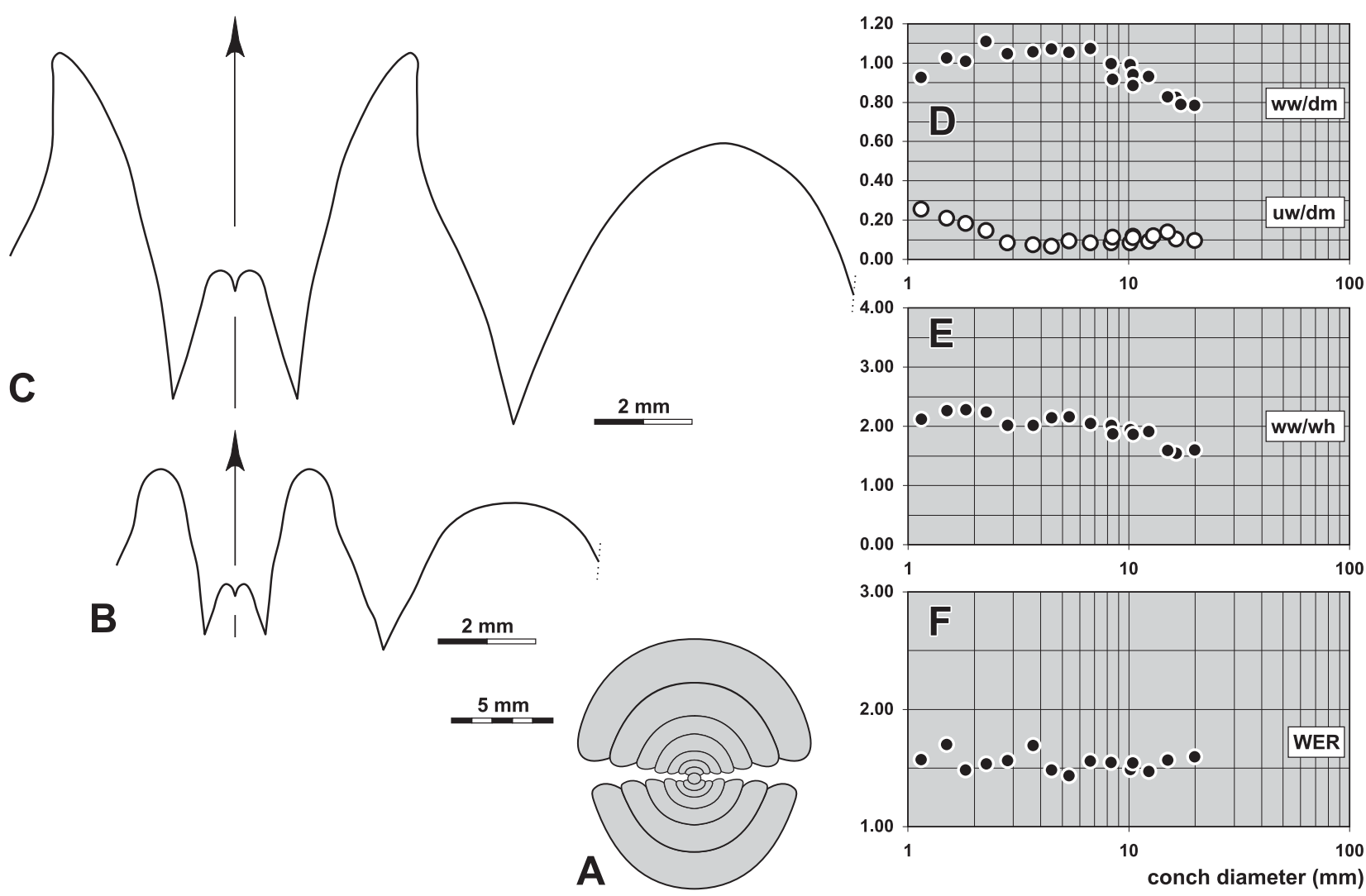

Figure 100. Progoniatites globulus n. sp. A. Cross section of paratype MB.C.18879.2 from locality MOU-D1; $\times 2.5$. B. Suture line of paratype MB.C.18775.1 from locality MOU-A, at $10.3 \mathrm{~mm} \mathrm{dm}, 9.7 \mathrm{~mm} w w, 5.7 \mathrm{~mm}$ wh; $\times 6.0$. C. Suture line of holotype MB.C.18879.1 from locality MOU-D1, at $18.8 \mathrm{~mm} \mathrm{dm}, 15.5 \mathrm{~mm}$ ww, $9.4 \mathrm{~mm}$ wh; $\times 6.0$. D-F. Ontogenetic development of the conch width index (ww/dm), umbilical width index (uw/dm), whorl width index (ww/wh), and whorl expansion rate (WER) of all available specimens.

\section{Subfamily Habadraitinae n. subfam.}

Subfamily definition. Goniatitidae with a simple conch ontogeny. Early ontogeny up to $2-3 \mathrm{~mm}$ conch diameter pachyconic or globular with almost constant ww/dm ratio, the conch becomes continuously more slender in later ontogeny. Early juvenile stage subinvolute; rapid narrowing of the umbilicus. Suture line with parallel-sided or diverging external lobe $(E L$ w/d $=0.65-1.00 ; \mathrm{EL} / \mathrm{AL}=1.20-1.60)$ with sinuous flanks and with asymmetric, rounded ventrolateral saddle.

Included genera.

Habadraites n. gen.

Primogoniatites $\mathrm{n}$. gen.

\section{Habadraites n. gen.}

Derivation of name. After the waterhole Hassi Habadra near the fossil locality.

Type species. Habadraites weyeri $\mathrm{n}$. sp.

Genus definition: Goniatitidae with rather small conch, reaching a conch diameter of up to $50 \mathrm{~mm}$. Early whorls subinvolute, slight closure of the umbilicus in juvenile stages smaller than $4 \mathrm{~mm}$ conch diameter. Suture line with narrow or moderately narrow and trapezoidal external lobe (EL $\mathrm{w} / \mathrm{d}=0.65-1.00 ; \mathrm{EL} / \mathrm{AL}=1.45-1.60)$ and moderately low median saddle ( $\mathrm{MS} \mathrm{h}=0.38-0.50)$; ventrolateral saddle narrowly rounded, almost symmetric; adventive lobe V-shaped, asymmetric.

Included species.

weyeri: Habadraites weyeri n. sp.; Mouydir, Algeria.

supralatus: Habadraites supralatus n. sp.; Mouydir, Algeria.

Discussion. Habadraites resembles, in its conch shape and suture line, some species of Progoniatites and Antegoniatites. In these two genera, however, the ventrolateral saddle is subacute or even acute, which allows clear discrimination from Habadraites with a narrowly rounded ventrolateral saddle. Further sutural criteria to separate between these genera can be seen in the width of the external lobe: In this respect, Habadraites (where the external lobe amounts 1.40 of the adventive lobe) ranges between Progoniatites (1.00-1.20) and Antegoniatites (1.60). 
The conch shape offers additional criteria to distinguish Habadraites from Progoniatites and Antegoniatites. The aperture in Habadraites (WER $\sim 1.95$ at $20 \mathrm{~mm} \mathrm{dm}$ ) is higher than in Progoniatites (1.50-1.70) and in Antegoniatites (1.70).

Separation of the new species. The two species of Habadraites can be separated by conch and suture characters:

- H. weyeri - subinvolute at $20 \mathrm{~mm} \mathrm{dm}$; EL w/d = nearly 0,75, flanks of external lobe nearly straight, adventive lobe V-shaped;

- H. supralatus - involute at $20 \mathrm{~mm} \mathrm{dm;} \mathrm{EL} \mathrm{w/d} \mathrm{=} \mathrm{nearly} \mathrm{1.00,} \mathrm{flanks} \mathrm{of} \mathrm{external} \mathrm{lobe} \mathrm{sinuous,} \mathrm{adventive} \mathrm{lobe} \mathrm{inflated.}$

\section{Habadraites weyeri n. sp.}

Figures 101, 102

Derivation of name. After Dieter Weyer (Berlin), for his cooperation in the field.

Holotype. Specimen MB.C.19030.1, illustrated in Figure 101A.

Type locality and horizon. Oued Temertasset, locality and sample MOU-V (Mouydir, South Algeria); lower part of the Pericyclus-Progoniatites Assemblage.

Material. 24 specimens, conch diameter up to $20 \mathrm{~mm}$.

Diagnosis. Habadraites with thickly pachyconic to thinly globular, subinvolute conch in the juvenile and preadult stage (up to $7 \mathrm{~mm}$ dm), thereafter becoming more slender and being thickly discoidal at $20 \mathrm{~mm} \mathrm{dm}$; umbilical margin subangular; aperture low in juveniles and becoming moderate during ontogeny. Steinkern with gentle constrictions, which extend concavo-convex with very shallow ventral sinus. Suture line with narrow or moderately narrow external lobe; median saddle moderately low; ventrolateral saddle narrowly rounded; adventive lobe V-shaped, slightly asymmetric.

Table 145. Conch ontogeny (Figs 102A, F-H) of Habadraites weyeri n. sp.

\begin{tabular}{|c|c|c|c|}
\hline $\mathrm{dm}$ & conch shape & whorl cross section shape & aperture \\
\hline $2 \mathrm{~mm}$ & $\begin{array}{l}\text { thinly globular; subinvolute } \\
\text { (ww/dm } \sim 0.86 ; \text { uw/dm } \sim 0.24 \text { ) }\end{array}$ & $\begin{array}{l}\text { moderately depressed; very strongly embracing } \\
\text { (ww/wh } \sim 1.90 ; \text { IZR } \sim 0.50 \text { ) }\end{array}$ & $\begin{array}{l}\text { low } \\
(\text { WER } \sim 1.65)\end{array}$ \\
\hline $8 \mathrm{~mm}$ & $\begin{array}{l}\text { thinly to thickly pachyconic; subinvolute } \\
\text { (ww/dm }=0.68-0.75 ; u w / d m=0.15-0.20 \text { ) }\end{array}$ & $\begin{array}{l}\text { moderately depressed; strongly embracing } \\
\text { (ww/wh } \sim 1.55 ; \text { IZR } \sim 0.44 \text { ) }\end{array}$ & $\begin{array}{l}\text { moderate } \\
(\text { WER } \sim 1.90)\end{array}$ \\
\hline $20 \mathrm{~mm}$ & $\begin{array}{l}\text { thickly discoidal; subinvolute } \\
\text { (ww/dm } \sim 0.55 ; \text { uw/dm } \sim 0.16 \text { ) }\end{array}$ & $\begin{array}{l}\text { weakly depressed; strongly embracing } \\
(\text { ww/wh }=1.10-1.30 ; \text { IZR }=0.40-0.45)\end{array}$ & $\begin{array}{l}\text { moderate } \\
(\mathrm{WER}=1.85-1.95)\end{array}$ \\
\hline
\end{tabular}

Table 146. Conch dimensions (in $\mathrm{mm}$ ) and proportions for reference specimens of Habadraites weyeri $\mathrm{n}$. sp.

\begin{tabular}{|c|c|c|c|c|c|c|c|c|c|c|}
\hline & $\mathrm{dm}$ & wW & wh & uw & ah & $w w / d m$ & ww/wh & $\mathrm{uw} / \mathrm{dm}$ & WER & IZR \\
\hline holotype MB.C.19030.1 & 20.5 & 11.6 & 10.3 & 3.1 & 5.8 & 0.56 & 1.13 & 0.15 & 1.94 & 0.44 \\
\hline paratype MB.C.18830 & 19.7 & 11.0 & 8.6 & 3.2 & 5.2 & 0.56 & 1.28 & 0.16 & 1.85 & 0.40 \\
\hline paratype MB.C.18925.1 & 18.8 & 11.3 & 9.0 & 2.7 & 5.3 & 0.60 & 1.26 & 0.14 & 1.94 & 0.41 \\
\hline paratype MB.C.18776.1 & 15.8 & 9.5 & 7.5 & 2.2 & 4.5 & 0.60 & 1.27 & 0.14 & 1.94 & 0.41 \\
\hline paratype MB.C.18776.2 & 10.5 & 7.4 & 4.9 & 1.3 & 2.9 & 0.70 & 1.52 & 0.12 & 1.90 & 0.41 \\
\hline
\end{tabular}
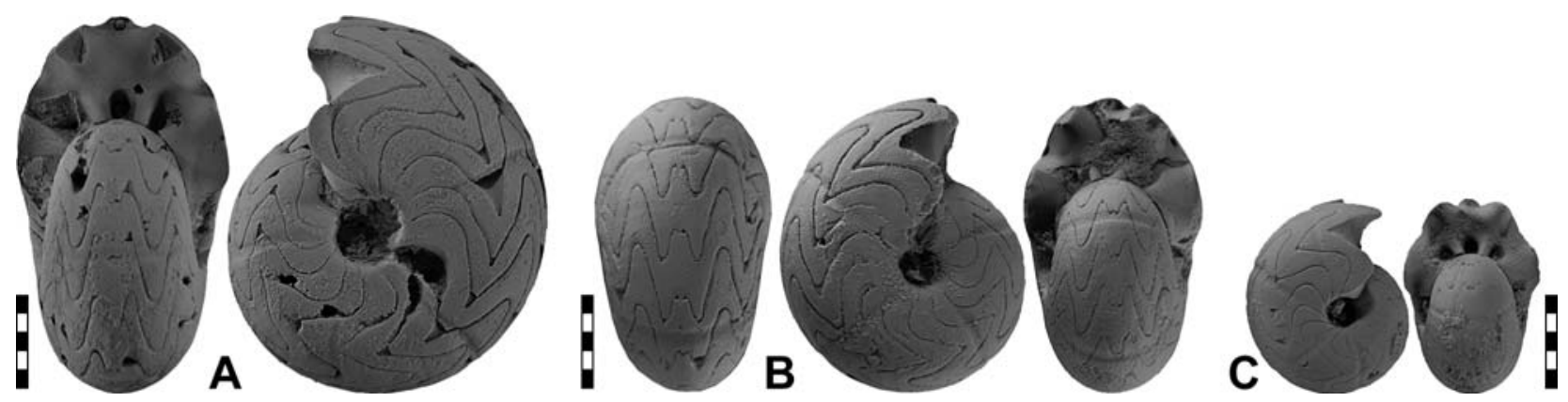

Figure 101. Habadraites weyeri n. sp.; all $\times 2$. A. Holotype MB.C.19030.1 from locality MOU-V. B. Paratype MB.C.18776.1 from locality MOU-A. C. Paratype MB.C.18776.2 from locality MOU-A. 
Table 147. Suture line proportions (Figs 102B-E) for Habadraites weyeri n. sp.

\begin{tabular}{llllllll}
\hline specimen & at dm & EL w/d & EL/VLS & EL/AL & MS h & VLS w/h & remarks \\
\hline holotype MB.C.19030.1 & $20.4 \mathrm{~mm}$ & 0.72 & 1.62 & 1.55 & 0.48 & 0.44 & prongs of E lobe subacute \\
paratype MB.C.18925.1 & $16.5 \mathrm{~mm}$ & 0.79 & 1.83 & 1.45 & 0.39 & 0.43 & M saddle comparatively low \\
paratype MB.C.18776.1 & $15.1 \mathrm{~mm}$ & 0.67 & 1.57 & 1.58 & 0.42 & 0.42 & 0.39 \\
paratype MB.C.18776.2 & $10.5 \mathrm{~mm}$ & 0.79 & 2.03 & 1.45 & 0.35 & \\
\hline
\end{tabular}
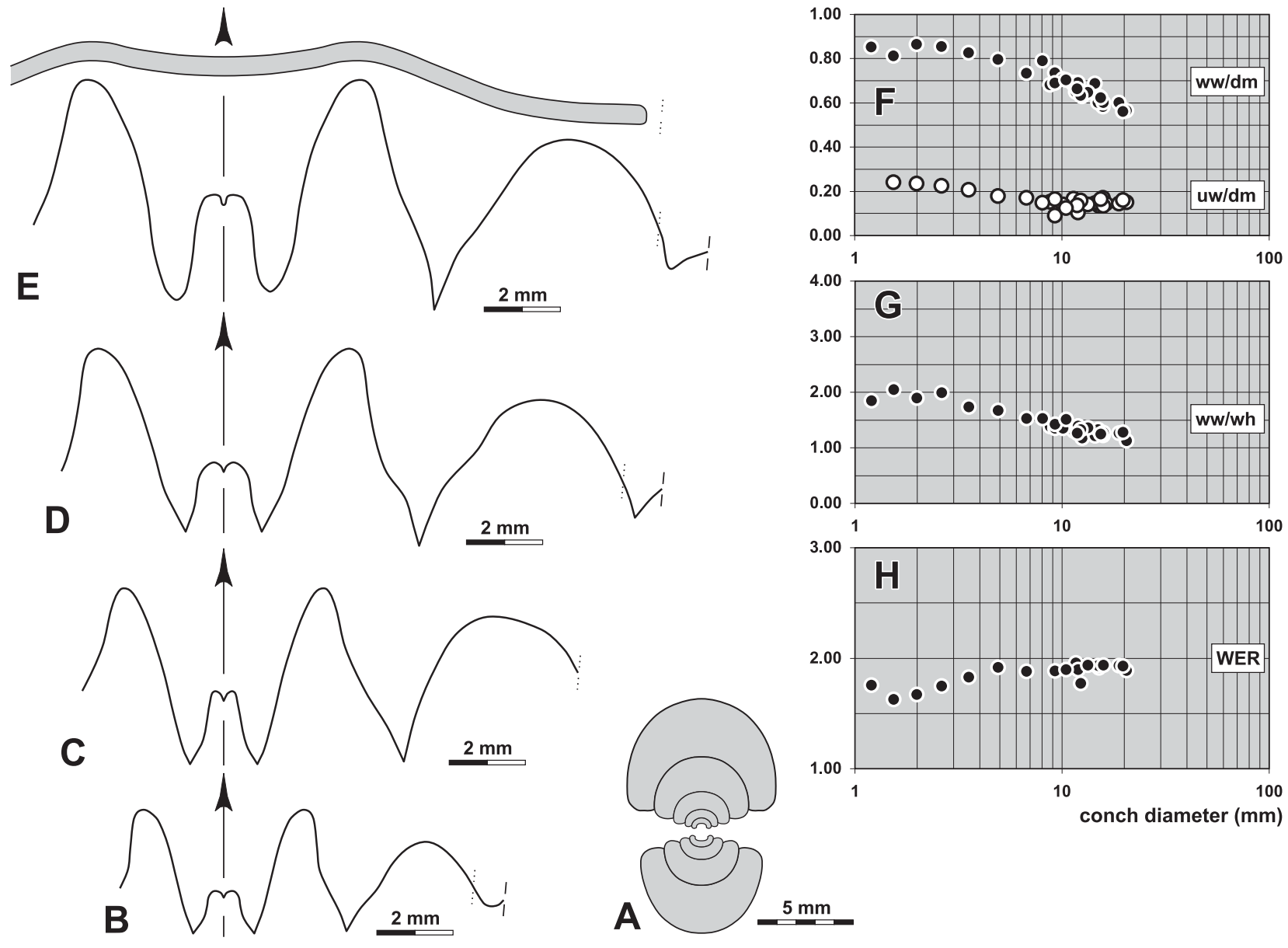

Figure 102. Habadraites weyeri n. sp. A. Cross section of paratype MB.C.19030.2 from locality MOU-V; $\times 2.5$. B. Suture line of paratype MB.C.18776.2 from locality MOU-A, at $10.7 \mathrm{~mm} \mathrm{dm}, 7.0 \mathrm{~mm}$ ww, $5.6 \mathrm{~mm} \mathrm{wh;} \times 5.0$. C. Suture line of paratype MB.C.18776.1 from locality MOU-A, at $15.1 \mathrm{~mm} \mathrm{dm}, 9.5 \mathrm{~mm}$ ww, $7.5 \mathrm{~mm}$ wh; $\times 5.0$. D. Suture line of paratype MB.C.18925.1 from locality MOU-E03, at $16.5 \mathrm{~mm} \mathrm{dm}, 10.0 \mathrm{~mm}$ ww, $8.3 \mathrm{~mm}$ wh; $\times 5.0$. E. Suture line and steinkern constriction of holotype MB.C.19030.1 from locality MOU-V, at $20.4 \mathrm{~mm} \mathrm{dm}, 11.5 \mathrm{~mm}$ ww, $10.2 \mathrm{~mm}$ wh; $\times 5.0$. F $-\mathbf{H}$. Ontogenetic development of the conch width index (ww/dm), umbilical width index (uw/dm), whorl width index (ww/wh), and whorl expansion rate (WER) of all available specimens.

\section{Habadraites supralatus n. sp.}

Figures 103, 104

Derivation of name. After the wide external lobe.

Holotype. Specimen MB.C.18881.1, illustrated in Figure 103A.

Type locality and horizon. Oued Temertasset, locality and sample MOU-D1 (Mouydir, South Algeria); upper Pericyclus-Progoniatites Assemblage.

Material. 14 specimens, conch diameter up to $29 \mathrm{~mm}$.

Diagnosis. Habadraites with thickly pachyconic to thinly globular, subinvolute conch in the juvenile and preadult stage (up to 7 mm dm), thereafter becoming more slender and being thickly discoidal and involute at $30 \mathrm{~mm} \mathrm{dm}$; umbilicus funnel-shaped with subangular margin; aperture moderate throughout ontogeny. Steinkern with gentle constrictions, which extend concavo-convex with shallow ventral sinus. Suture line with moderately narrow external lobe; median saddle low; ventrolateral saddle rounded; adventive lobe asymmetric with convex flanks. 
Table 148. Conch ontogeny (Figs 104A, D-F) of Habadraites supralatus n. sp.

\begin{tabular}{|c|c|c|c|}
\hline $\mathrm{dm}$ & conch shape & whorl cross section shape & aperture \\
\hline $2 \mathrm{~mm}$ & $\begin{array}{l}\text { thinly globular; subinvolute } \\
\text { (ww/dm } \sim 0.90 ; \text { uw/dm } \sim 0.20 \text { ) }\end{array}$ & $\begin{array}{l}\text { moderately depressed; very strongly embracing } \\
(\mathrm{ww} / \mathrm{wh} \sim 1.90 \text {; IZR } \sim 0.50)\end{array}$ & $\begin{array}{l}\text { moderate } \\
(\text { WER } \sim 1.75)\end{array}$ \\
\hline $8 \mathrm{~mm}$ & $\begin{array}{l}\text { thickly pachyconic; involute to subinvolute } \\
\text { (ww/dm }=0.75-0.80 ; \text { uw/dm }=0.10-0.18 \text { ) }\end{array}$ & $\begin{array}{l}\text { weakly depressed; very strongly embracing } \\
(\text { ww/wh }=1.40-1.50 ; \text { IZR } \sim 0.45)\end{array}$ & $\begin{array}{l}\text { moderate } \\
(\text { WER } \sim 1.90)\end{array}$ \\
\hline $20 \mathrm{~mm}$ & $\begin{array}{l}\text { thickly discoidal; involute } \\
\text { (ww/dm =0.55-0.60; uw/dm 0.10) }\end{array}$ & $\begin{array}{l}\text { weakly depressed; very strongly embracing } \\
\text { (ww/wh } \sim 1.10 \text {; IZR } \sim 0.48 \text { ) }\end{array}$ & $\begin{array}{l}\text { moderate } \\
(\text { WER } \sim 1.90)\end{array}$ \\
\hline $30 \mathrm{~mm}$ & $\begin{array}{l}\text { thickly discoidal; involute } \\
\text { (ww/dm =0.55-0.60; uw/dm } \sim 0.10 \text { ) }\end{array}$ & $\begin{array}{l}\text { weakly depressed; very strongly embracing } \\
\text { (ww/wh } \sim 1.10 ; \text { IZR } \sim 0.48)\end{array}$ & $\begin{array}{l}\text { moderate } \\
(\text { WER } \sim 1.90)\end{array}$ \\
\hline
\end{tabular}
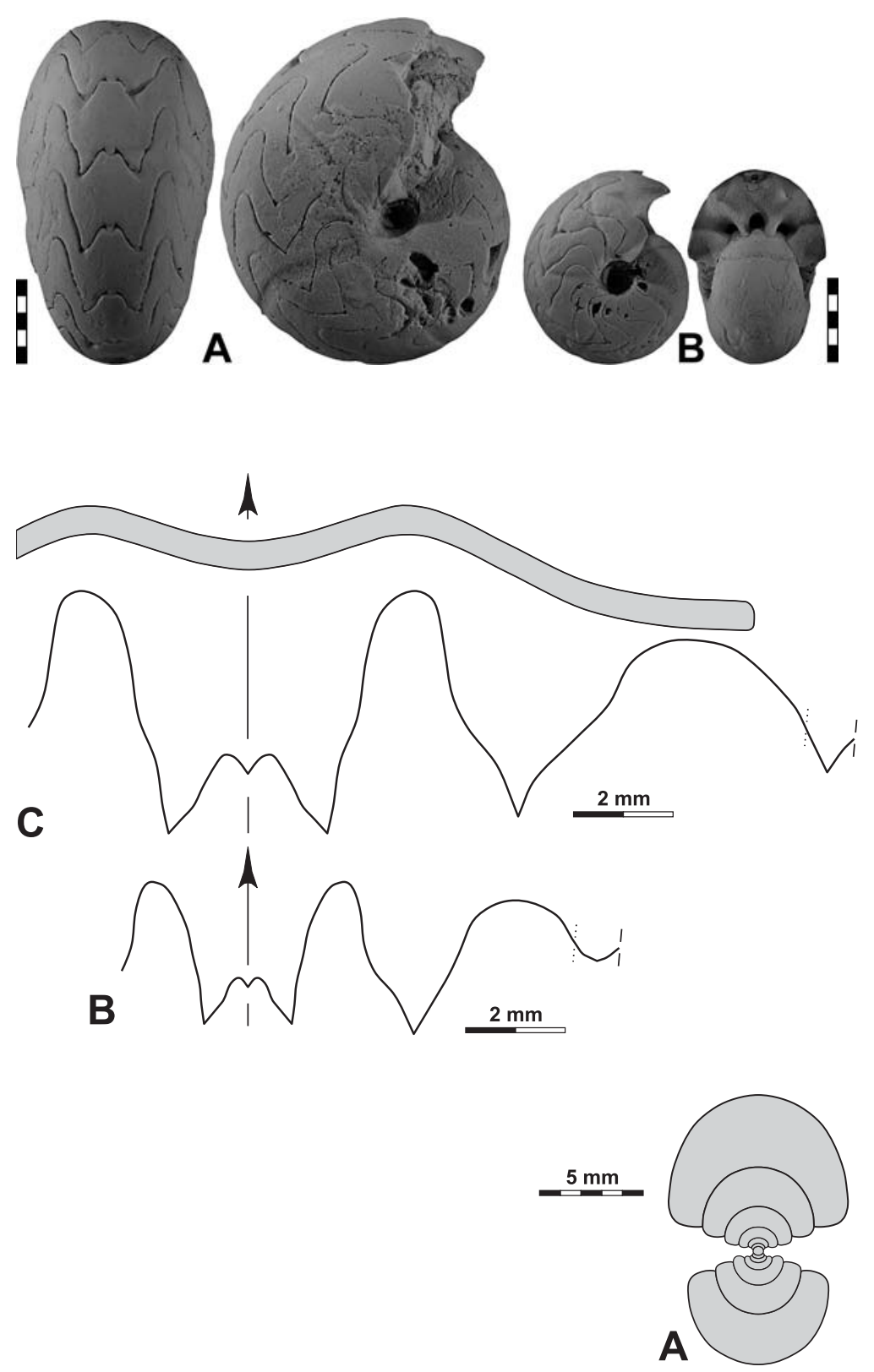

Figure 103. Habadraites supralatus $\quad$ n. sp.; all $\times 2$. A. Holotype MB.C.18881.1 from locality MOU-D1. B. Paratype MB.C.19031.1 from locality MOU-V.
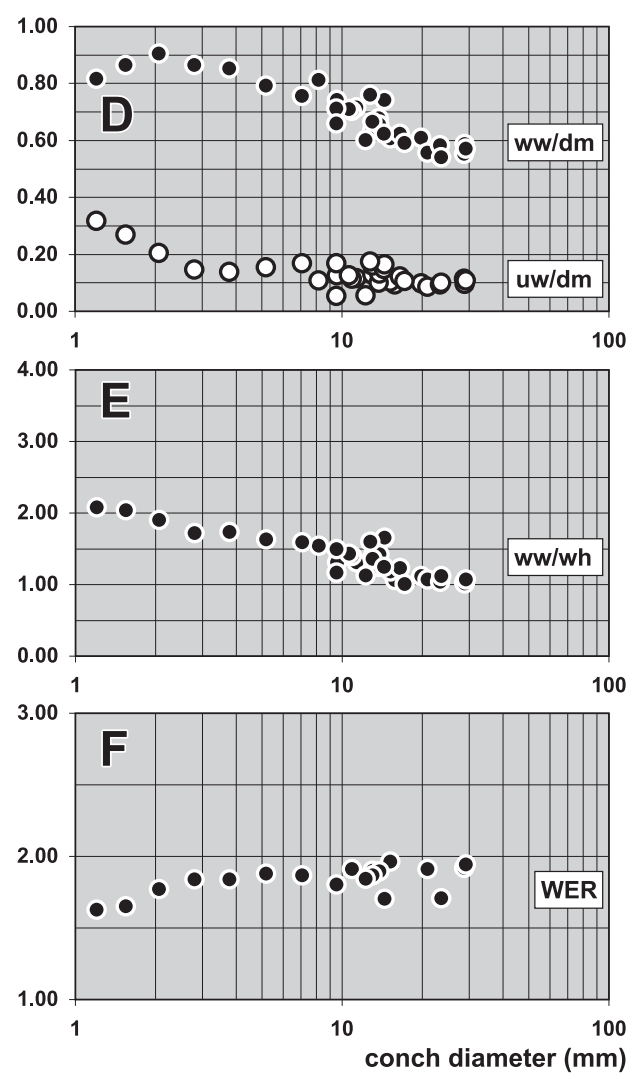

Figure 104. Habadraites supralatus n. sp. A. Cross section of paratype MB.C.19031.2 from locality MOU-V; $\times 2.5$. B. Suture line of paratype MB.C.19031.1 from locality MOU-A, at $13.7 \mathrm{~mm} \mathrm{dm}, 9.0 \mathrm{~mm} w w, 6.3 \mathrm{~mm}$ wh; $\times 6.0$. C. Suture line and steinkern constriction of holotype MB.C.18881.1 from locality MOU-D1, at $20.8 \mathrm{~mm} \mathrm{dm}, 11.6 \mathrm{~mm} w w, 10.8 \mathrm{~mm}$ wh; $\times 6.0$. D-F. Ontogenetic development of the conch width index (ww/dm), umbilical width index (uw/dm), whorl width index (ww/wh), and whorl expansion rate (WER) of all available specimens. 
Table 149. Conch dimensions (in $\mathrm{mm}$ ) and proportions for reference specimens of Habadraites supralatus $\mathrm{n}$. $\mathrm{sp}$.

\begin{tabular}{lrrrrrrrrrrr}
\hline & dm & ww & wh & uw & ah & ww/dm & ww/wh & uw/dm & WER & IZR \\
\hline holotype MB.C.18881.1 & 20.9 & 11.7 & 10.9 & 1.8 & 5.8 & 0.56 & 1.07 & 0.09 & 1.91 & 0.47 \\
paratype MB.C.18881.2 & 15.1 & 9.2 & 7.8 & 1.6 & 4.3 & 0.61 & 1.18 & 0.10 & 1.97 & 0.44 \\
paratype MB.C.19031.1 & 13.8 & 9.1 & 6.4 & 1.8 & 3.8 & 0.66 & 1.42 & 0.13 & 1.90 & 0.41 \\
\hline
\end{tabular}

Table 150. Suture line proportions (Figs 104B, C) for Habadraites supralatus n. sp.

\begin{tabular}{llllllll}
\hline specimen & at dm & EL w/d & EL/VLS & EL/AL & MS h & VLS w/h & remarks \\
\hline holotype MB.C.18881.1 & $20.8 \mathrm{~mm}$ & 0.98 & 2.40 & 1.55 & 0.32 & 0.41 \\
paratype MB.C.19031.1 & $13.7 \mathrm{~mm}$ & 0.79 & 1.79 & 1.27 & 0.32 & 0.44 \\
\hline
\end{tabular}

\section{Primogoniatites n. gen.}

Derivation of name. Combination of the Latin prefix primo and Goniatites, to point out the course of the suture line, which is considered plesiomorphic.

Type species. Primogoniatites fundator $\mathrm{n}$. sp.

Genus definition. Goniatitidae with rather small conch, reaching $50 \mathrm{~mm}$ in conch diameter. Early whorls subinvolute, slight closure of the umbilicus in juvenile stages smaller than $5 \mathrm{~mm}$ conch diameter. Suture line parallel-sided, in the lower half pouched narrow external lobe (EL $\mathrm{w} / \mathrm{d} \sim 0.70$; EL/AL $\sim 1.20$ ) and moderately low median saddle $(\mathrm{MS} \mathrm{h} \sim 0.45$ ); ventrolateral saddle rounded, slightly asymmetric; adventive lobe V-shaped, asymmetric.

Included species.

fundator: Primogoniatites fundator n. sp.; Mouydir, Algeria.

Discussion. Primogoniatites resembles Habadraites in conch shape and suture line, but Habadraites has a subtrapezoidal external lobe with diverging flanks, unlike the pouched external lobe with subparallel flanks in Primogoniatites.

\section{Primogoniatites fundator n. sp.}

Figures 105, 106

Derivation of name. From Latin fundator $=$ founder, because the species might be close to the origin of the Goniatitidae.

Holotype. Specimen MB.C.18777.1, illustrated in Figure 105A.

Type locality and horizon. Oued Temertasset, locality and sample MOU-A (Mouydir, South Algeria); upper Pericyclus-Progoniatites Assemblage.

Material. 37 specimens, conch diameter up to $30 \mathrm{~mm}$.

Diagnosis. Primogoniatites with thinly globular, subinvolute early juvenile conch, thereafter becoming continuously more slender and being thickly discoidal and involute at $30 \mathrm{~mm} \mathrm{dm}$; conch is thickest near the narrowly rounded umbilical margin, from where the flanks converge to the widely rounded venter; aperture moderate in juveniles and high in the adult stage. Steinkern with constrictions, course convex with moderately deep ventral sinus; faint spiral lines are on the venter of the steinkern. Suture line with narrow external lobe; median saddle low; ventrolateral saddle asymmetric and rounded; adventive lobe V-shaped, slightly inflated.

Table 151. Conch ontogeny (Figs 106A, B, D-F) of Primogoniatites fundator n. sp.

\begin{tabular}{|c|c|c|c|}
\hline $\mathrm{dm}$ & conch shape & whorl cross section shape & aperture \\
\hline $2 \mathrm{~mm}$ & $\begin{array}{l}\text { thinly globular; subinvolute } \\
\text { (ww/dm } \sim 0.90 ; \text { uw/dm } \sim 0.29 \text { ) }\end{array}$ & $\begin{array}{l}\text { strongly depressed; strongly embracing } \\
\text { (ww/wh } \sim 2.20 \text {; IZR } \sim 0.38 \text { ) }\end{array}$ & $\begin{array}{l}\text { moderate } \\
(\text { WER } \sim 1.80)\end{array}$ \\
\hline $8 \mathrm{~mm}$ & $\begin{array}{l}\text { thinly pachyconic; involute to subinvolute } \\
(\mathrm{ww} / \mathrm{dm}=0.68-0.72 ; \mathrm{uw} / \mathrm{dm}=0.12-0.18)\end{array}$ & $\begin{array}{l}\text { weakly depressed; strongly embracing } \\
(\mathrm{ww} / \mathrm{wh}=1.40-1.50 ; \text { IZR } \sim 0.40)\end{array}$ & $\begin{array}{l}\text { moderate } \\
(\text { WER } \sim 1.95)\end{array}$ \\
\hline $20 \mathrm{~mm}$ & $\begin{array}{l}\text { thickly discoidal to thinly pachyconic; involute } \\
(\mathrm{ww} / \mathrm{dm}=0.55-0.70 ; \mathrm{uw} / \mathrm{dm}=0.10-0.15)\end{array}$ & $\begin{array}{l}\text { weakly depressed; strongly embracing } \\
(\mathrm{ww} / \mathrm{wh}=1.10-1.25 ; \mathrm{IZR}=0.35-0.45)\end{array}$ & $\begin{array}{l}\text { high } \\
(\text { WER }=2.00-2.15)\end{array}$ \\
\hline $30 \mathrm{~mm}$ & $\begin{array}{l}\text { thickly discoidal; involute } \\
(w w / d m=0.52-0.60 ; u w / d m=0.10-0.15)\end{array}$ & $\begin{array}{l}\text { weakly depressed; strongly embracing } \\
(\mathrm{ww} / \mathrm{wh}=1.10-1.25 ; \mathrm{IZR}=0.35-0.40)\end{array}$ & $\begin{array}{l}\text { high } \\
(\text { WER }=2.00-2.15)\end{array}$ \\
\hline
\end{tabular}


Table 152. Conch dimensions (in $\mathrm{mm}$ ) and proportions for reference specimens of Primogoniatites fundator $\mathrm{n}$. sp.

\begin{tabular}{lllllllllll}
\hline & $\mathrm{dm}$ & ww & wh & uw & ah & ww/dm & ww/wh & uw/dm & WER & IZR \\
\hline holotype MB.C.18777.1 & 27.7 & 16.6 & 14.4 & 4.2 & 8.8 & 0.60 & 1.16 & 0.15 & 2.15 & 0.39 \\
paratype MB.C.18804.4 & 24.1 & 14.4 & 12.9 & 3.0 & 7.6 & 0.60 & 1.12 & 0.12 & 2.14 & 0.41 \\
paratype MB.C.18804.1 & 22.4 & 12.6 & 11.0 & 2.8 & 6.9 & 0.56 & 1.14 & 0.12 & 2.09 & 0.37 \\
paratype MB.C.18804.2 & 21.6 & 12.8 & 11.2 & 2.8 & 6.5 & 0.59 & 1.14 & 0.13 & 2.04 & 0.42 \\
paratype MB.C.18804.5 & 21.3 & 13.8 & 10.9 & 2.7 & 6.1 & 0.65 & 1.26 & 0.13 & 1.97 & 0.44 \\
\hline
\end{tabular}

Table 153. Suture line proportions (Fig. 106C) for Primogoniatites fundator n. sp.

\begin{tabular}{llllllll}
\hline specimen & at dm & EL w/d & EL/VLS & EL/AL & MS h & VLS w/h & remarks \\
\hline paratype MB.C.18804.2 & $18.9 \mathrm{~mm}$ & 0.69 & 1.55 & 1.20 & 0.28 & 0.44 & A lobe slightly inflated \\
\hline
\end{tabular}
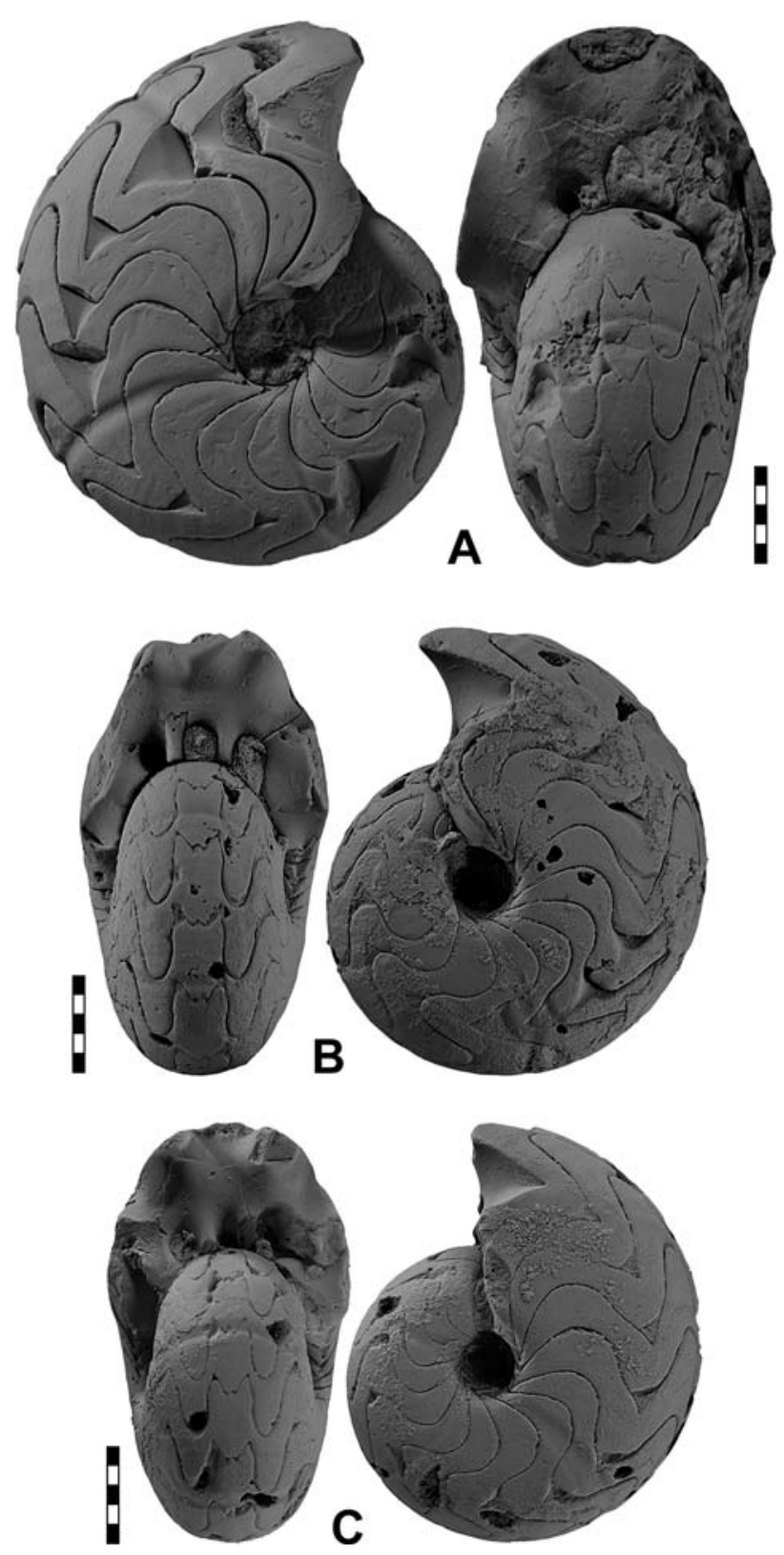

Figure 105. Primogoniatites fundator $\mathrm{n} . \mathrm{sp}$; all $\times 2$. A. Holotype MB.C.18777.1 from locality MOU-A. B. Paratype MB.C.18804.1 from locality MOU-B0. C. Paratype MB.C.18804.2 from locality MOU-B0. 


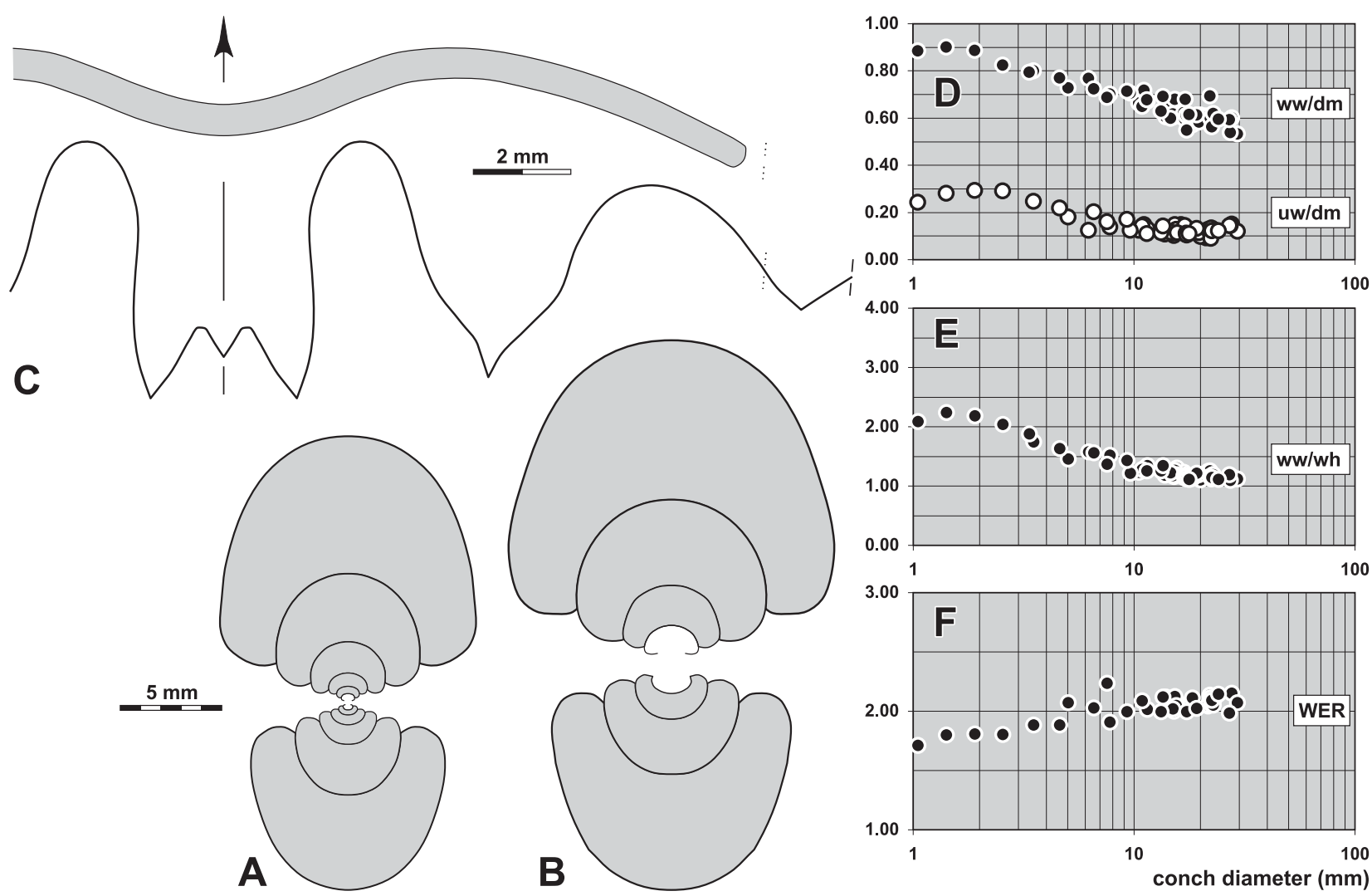

Figure 106. Primogoniatites fundator n. sp. A. Cross section of paratype MB.C.18777.2 from locality MOU-A; $\times 2.5$. B. Cross section of paratype MB.C.18804.3 from locality MOU-B0; $\times 2.5$. C. Suture line and steinkern constriction of paratype MB.C.18804.2 from locality MOU-B0, at $18.9 \mathrm{~mm} \mathrm{dm}, 11.5 \mathrm{~mm}$ ww, $10.6 \mathrm{~mm}$ wh; $\times 6.0$. D-F. Ontogenetic development of the conch width index (ww/dm), umbilical width index (uw/dm), whorl width index (ww/wh), and whorl expansion rate (WER) of all available specimens.

\section{Subfamily Antegoniatitinae n. subfam.}

Subfamily definition. Goniatitidae with a rather complex conch ontogeny. Early ontogeny up to $4-5 \mathrm{~mm}$ conch diameter thickly discoidal with almost constant ww/dm ratio, the conch becomes continuously stouter in later ontogeny. Early juvenile stage evolute. Suture line with strongly diverging external lobe $(\mathrm{EL} \mathrm{w} / \mathrm{d}>0.75 ; \mathrm{EL} / \mathrm{AL}>1.50)$ and with symmetric, acute ventrolateral saddle.

Included genus.

Antegoniatites n. gen.

\section{Antegoniatites n. gen.}

Derivation of name. Combination of the Latin prefix ante and Goniatites, to point out the suture line with very wide elements, which is only known from other much younger species.

Type species. Antegoniatites anticiparis n. sp.

Genus definition. Goniatitidae with small conch, reaching $30 \mathrm{~mm}$ in diameter. Juvenile whorls evolute, closure of the umbilicus already in the juvenile stage. Suture line with moderately narow V-shaped external lobe (EL w/d >0.75; EL/AL > 1.50) and moderately high median saddle (MS h $=0.55-0.60)$; ventrolateral saddle acute, almost symmetric with nearly straight flanks.

Included species.

anticiparis: Antegoniatites anticiparis n. sp.; Mouydir, Algeria.

Discussion. Antegoniatites is a very strange component in the early Late Tournaisian ammonoid fauna of the Mouydir. Goniatites with such a suture line were so far only known from Neogoniatites, a genus that occurs in Viséan-Serpukhovian boundary beds (Ruzhencev \& Bogoslovskaya 1971). The sutures of the two genera display astonishing similarities in the width ratios of their elements and their shapes, with the exception that the flanks of the adventive lobe are a little bit more sinuous in Neogoniatites. The main character to separate the two genera is the ontogenetic development of the conch shape. Antegoniatites has a relatively long widely umbilicate ontogenetic stage, which in Neogoniatites is extremely short and restricted to the initial stage. 
Progoniatites has an almost time-equivalent occurrence; it is separated from Antegoniatites by the suture line, which has a much narrower external lobe $(\mathrm{EL} / \mathrm{AL}=0.90-1.40$ in contrast to a value of more than 1.50 in Antegoniatites) and a much lower median saddle (MS h $=0.35-0.40$ in Progoniatites but 0.55-0.60 in Antegoniatites). The ventrolateral saddle is subtriangular and nearly symmetric in Antegoniatites but strikingly asymmetric in Progoniatites. The early widely umbilicate stage of Progoniatites is much shorter.

\section{Antegoniatites anticiparis n. sp.}

Figures 107, 108

Derivation of name. From Latin anticiparis = anticipating, because of the very progressive suture line.

Holotype. Specimen MB.C.19052.1, illustrated in Figure 107A.

Type locality and horizon. Oued Temertasset, locality and sample MOU-Y (Mouydir, South Algeria); Helicocyclus-Ouaoufilalites Assemblage. Material. 20 specimens, conch diameter up to $21 \mathrm{~mm}$.

Diagnosis. Antegoniatites with thinly pachyconic, evolute conch in the early juvenile stage (at $2 \mathrm{~mm}$ dm), thereafter rapidly becoming subinvolute; umbilical margin rounded; aperture low or moderately high throughout ontogeny. Steinkern with gentle constrictions, which extend in a convex course. Suture line with moderately narrow external lobe; median saddle moderately high; ventrolateral saddle subtriangular, almost symmetric and acute; adventive lobe V-shaped and slightly asymmetric with gently curved ventral flank.

Table 154. Conch ontogeny (Figs 108A, B, E-G) of Antegoniatites anticiparis n. sp.

\begin{tabular}{|c|c|c|c|}
\hline$d m$ & conch shape & whorl cross section shape & aperture \\
\hline $2 \mathrm{~mm}$ & $\begin{array}{l}\text { thinly pachyconic; evolute } \\
(\mathrm{ww} / \mathrm{dm} \sim 0.60 ; \mathrm{uw} / \mathrm{dm}=0.50)\end{array}$ & $\begin{array}{l}\text { strongly depressed; very strongly embracing } \\
\text { (ww/wh } \sim 2.10 ; \text { IZR } \sim 0.48 \text { ) }\end{array}$ & $\begin{array}{l}\text { low } \\
(\text { WER } \sim 1.55)\end{array}$ \\
\hline $8 \mathrm{~mm}$ & $\begin{array}{l}\text { thinly pachyconic; subinvolute } \\
(\mathrm{ww} / \mathrm{dm}=0.63-0.68 ; \mathrm{uw} / \mathrm{dm}=0.15-0.20)\end{array}$ & $\begin{array}{l}\text { weakly depressed; very strongly embracing } \\
\text { (ww/wh }=1.25-1.40 ; \text { IZR } \sim 0.50 \text { ) }\end{array}$ & $\begin{array}{l}\text { low to moderate } \\
(\text { WER } \sim 1.75)\end{array}$ \\
\hline $16 \mathrm{~mm}$ & $\begin{array}{l}\text { thickly discoidal to thinly pachyconic; } \\
\text { subinvolute (ww/dm }=0.55-0.65 ; \mathrm{ww} / \mathrm{dm}=0.15-0.20 \text { ) }\end{array}$ & $\begin{array}{l}\text { weakly depressed; very strongly embracing } \\
\text { (ww/wh }=1.25-1.40 ; \text { IZR } \sim 0.55)\end{array}$ & $\begin{array}{l}\text { low } \\
\text { (WER 1.65) }\end{array}$ \\
\hline
\end{tabular}

Table 155. Conch dimensions (in $\mathrm{mm}$ ) and proportions for reference specimens of Antegoniatites anticiparis n. sp.

\begin{tabular}{|c|c|c|c|c|c|c|c|c|c|c|}
\hline & $\mathrm{dm}$ & ww & wh & uw & ah & ww/dm & ww/wh & $\mathrm{uw} / \mathrm{dm}$ & WER & IZR \\
\hline holotype MB.C.19052.1 & 17.2 & 10.9 & 8.3 & 2.6 & 3.8 & 0.63 & 1.32 & 0.15 & 1.63 & 0.55 \\
\hline paratype MB.C.19052.6 & 12.9 & 7.7 & 6.4 & 1.3 & 3.1 & 0.59 & 1.19 & 0.10 & 1.75 & 0.51 \\
\hline paratype MB.C.19052.2 & 12.6 & 8.0 & 6.6 & 1.2 & 3.1 & 0.64 & 1.21 & 0.10 & 1.76 & 0.53 \\
\hline paratype MB.C.19052.7 & 11.6 & 7.2 & 5.8 & 1.0 & 2.8 & 0.62 & 1.24 & 0.09 & 1.75 & 0.51 \\
\hline paratype MB.C.19052.5 & 11.3 & 7.2 & 5.5 & 1.5 & 2.8 & 0.64 & 1.30 & 0.14 & 1.78 & 0.49 \\
\hline paratype MB.C.19052.3 & 6.0 & 3.7 & 2.4 & 1.6 & 1.4 & 0.61 & 1.51 & 0.26 & 1.70 & 0.42 \\
\hline
\end{tabular}

Table 156. Suture line proportions (Figs 108C, D) for Antegoniatites anticiparis n. sp.

\begin{tabular}{llllllll}
\hline specimen & at dm & EL w/d & EL/VLS & EL/AL & MS h & VLS w/h & remarks \\
\hline holotype MB.C.19052.1 & $18.4 \mathrm{~mm}$ & 0.83 & 1.78 & 1.64 & 0.60 & 0.47 & flanks of E lobe nearly straight \\
paratype MB.C.19052.4 & $13.9 \mathrm{~mm}$ & 0.75 & 1.87 & 1.52 & 0.55 & 0.39 & flanks of E lobe slightly sinuous \\
\hline
\end{tabular}
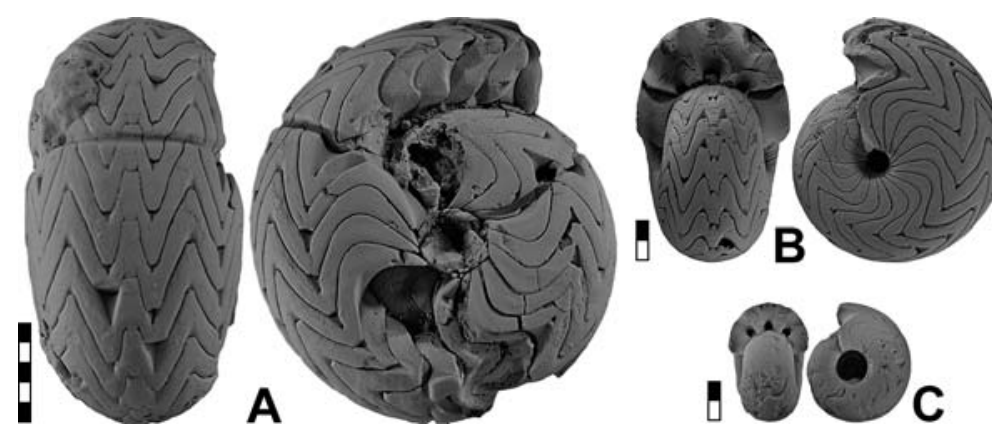

Figure 107. Antegoniatites anticiparis $\mathrm{n} . \mathrm{sp}$. from locality MOU-Y; all $\times 2$. A. Holotype MB.C.19052.1. B. Paratype MB.C.19052.2. C. Paratype MB.C.19052.3. 
Discussion. Antegoniatites anticiparis is easily separated from all other Tournaisian ammonoids, due to its sutural outline with a rather wide external lobe. It shows striking similarities to some end-Viséan species of Neogoniatites, but this resemblance is most probably a homoplasy.
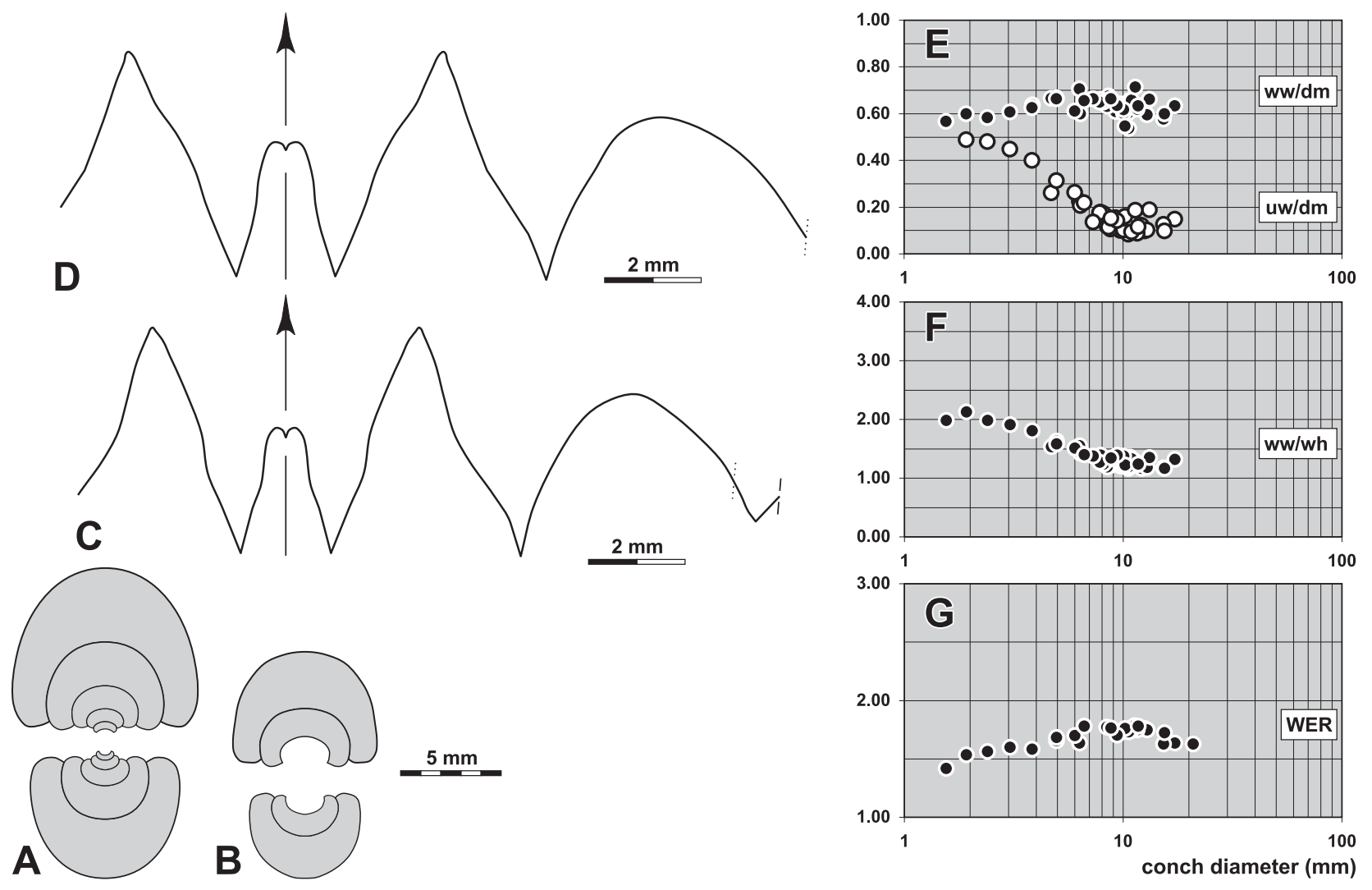

Figure 108. Antegoniatites anticiparis n. sp. from locality MOU-Y. A. Cross section of paratype MB.C.19052.4; $\times 2.5$. B. Cross section of paratype MB.C.19052.5; $\times 2.5$. C. Suture line of paratype MB.C.19052.4, at $13.9 \mathrm{~mm} \mathrm{dm,} 9.0 \mathrm{~mm}$ ww, $7.5 \mathrm{~mm}$ wh; $\times$ 6.0. D. Suture line of holotype MB.C.19052.1, at $18.4 \mathrm{~mm} \mathrm{dm}, 11.0 \mathrm{~mm}$ ww, $9.5 \mathrm{~mm} \mathrm{wh} ; \times 6.0$. E-G. Ontogenetic development of the conch width index (ww/dm), umbilical width index (uw/dm), whorl width index (ww/wh), and whorl expansion rate (WER) of all available specimens.

Order Prolecanitida Miller \& Furnish, 1954

Suborder Prolecanitina Miller \& Furnish, 1954

Superfamily Prolecanitaceae Hyatt, 1884

Family Prolecanitidae Hyatt, 1884

Subfamily Prolecanitinae Hyatt, 1884

\section{Becanites Korn, 1997}

For a detailed discussion of the genus, see Korn et al. (2010a).

\section{Becanites inflateralis Korn, Ebbighausen \& Bockwinkel, 2010}

Figures 109, 110

1984 Protocanites lyoni. - Conrad, pl. 5, fig. 6.

Material. Nine specimens, mostly fragments, conch diameter up to approximately $40 \mathrm{~mm}$.

Diagnosis. Becanites with extremely discoidal, subevolute conch at $20 \mathrm{~mm} \mathrm{dm}$; whorl cross section subquadrate; flanks flattened and parallel; venter slightly flattened; aperture high. Steinkern smooth. Suture line with pouched external lobe, broad and asymmetric adventive lobe with subparallel flanks, and pouched lateral lobe. 

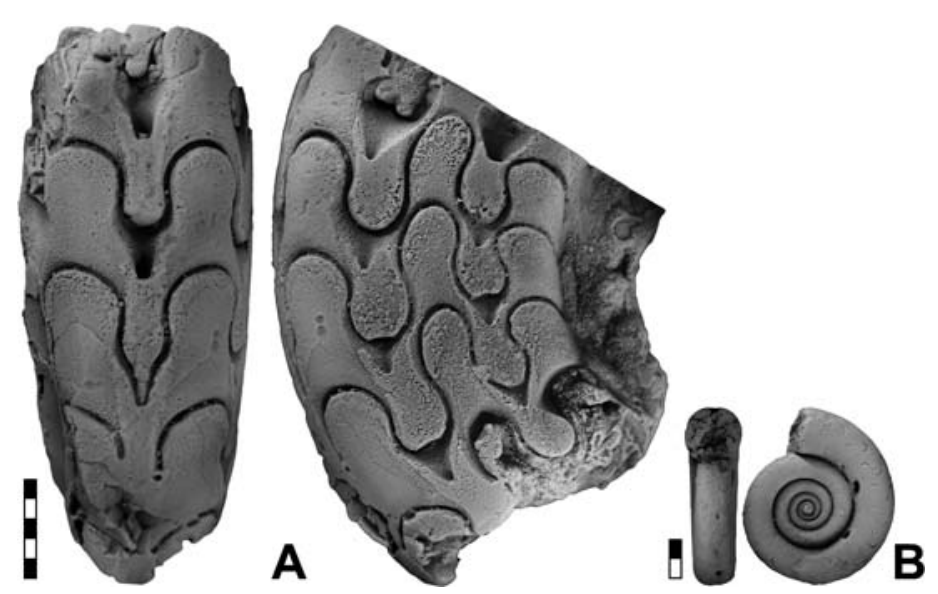

Figure 109. Becanites inflateralis $\quad$ n. sp.; all $\times 2$. A. Specimen MB.C. 18883 from locality MOUD1 B. Specimen MB.C.18778.1 from locality MOU-A.

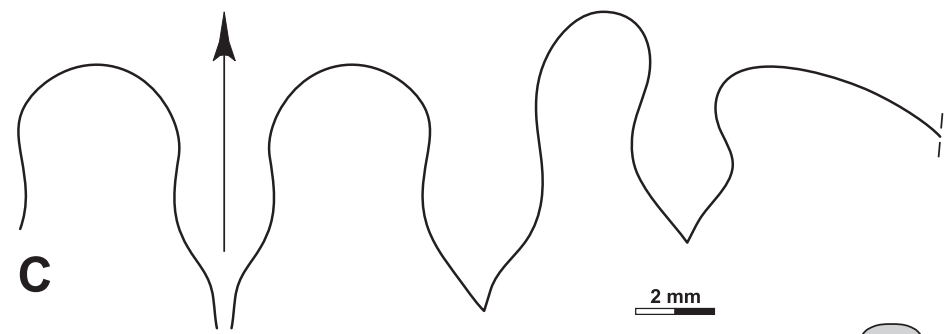

Figure 110. Becanites inflateralis n. sp. A. Dorsal view of specimen MB.C.18778.1 from locality MOU-A; $\times 2.5$. B. Suture line of specimen MB.C.18778.1 from locality MOU-A, at $8.4 \mathrm{~mm}$ $\mathrm{dm}, 2.6 \mathrm{~mm}$ ww, $2.2 \mathrm{~mm}$ wh; $\times 5.0$. C. Suture line of specimen MB.C.18883 from locality MOU-D1, at $11.5 \mathrm{~mm}$ ww, $13.2 \mathrm{~mm}$ wh; $\times 4.0$.

\section{Acknowledgements}

We are indebted to the regional Algerian authorities for their permission for us to undertake field work. D. K. acknowledges the Deutsche Forschungsgemeinschaft (DFG) for financial support (project Ko1829/3-1). Jobst Wendt (Tübingen) and his team (Simone Walker, Bernd Kaufmann, Christian Klug, Stefan Lubeseder, Jochen Rath) are acknowledged for the collection of the first material from Oued Temertasset and Hassi Habadra. Dieter Weyer (Berlin) joined us during the field session and contributed significantly to the collection. Technical support was provided by Wolfgang Gerber (Tübingen) for photographing most of the specimens. We thank Sonny Walton (Potsdam) for proofreading the manuscript and Christian Klug (Zürich) as well as David Work (Augusta) for a review of the article.

\section{References}

Barrois, C. 1882. Recherches sur les terrains anciens des Asturies et de la Galice. - Mémoires de la Société Géologique du Nord 2 (1): $1-630$.

Bisat, W. S. 1924. The Carboniferous goniatites of the north of England and their zones. - Proceedings of the Yorkshire Geological Society 20: 40-124.

Bockwinkel, J. \& Ebbighausen, V. 2006. A new ammonoid fauna from the Gattendorfia-Eocanites Genozone of the Anti-Atlas (Early Carboniferous, Morocco. - Fossil Record 9 (1): 87-129.

Brüning, K. 1923. Beiträge zur Kenntnis des Rheinisch-westfälischen Unterkarbons, insbesondere der Goniatiten und Korallen in der stratigraphischen Stellung und Gliederung. Marburg University: $59 \mathrm{pp}$.
Campbell, K. S. W., Brown, D. A. \& Coleman, A. R. 1983. Ammonoids and the correlation of the lower Carboniferous rocks of eastern Australia. - Alcheringa 7 (2): 75-123.

Chao, King-Koo \& Liang Xiluo 1964. Middle Carboniferous Cephalopoda. Handbook of Index fossils from Southern China: p. 87.

Conrad, J. 1966. Les goniatites des argiles viséennes du Mouydir (Sahara central). - Compte Rendue de la Societé Géologique de France 1966 (10): 408.

Conrad, J. 1967. Les goniatites des argiles viséennes du Mouydir (Sahara central). - Bulletin de la Societé Géologique de France 8 (6): 905-907.

Conrad, J. 1984. Les séries Carbonifères du Sahara Central Algérien stratigraphie, sédimentation, évolution structurale. Université de Droit, d'Economie et des Sciences d'Aix Marseille, Thèse de Doctorat d'Etat dès-Sciences naturelles. Marseille: 370 pp.

Conrad, J. \& Pareyn, C. 1968. Présence de Goniatites cf. crenistria Phillips à la base du Viséen inférieur, dans la bassin d'Habadra (Mouydir, Sahara central). - Comptes rendus de 1'Académie des Sciences 266 (6): 569-572.

Crick, G. C. 1899. On some new or little-known Goniatites from the Carboniferous limestone of Ireland. - The annals and magazine of natural history, zoology, botany and geology (7) 3: 429-454.

Currie, E. D. 1954. Scottish Carboniferous Goniatites. - Transactions of the Royal Society of Edinburgh 622 (14): 527-602.

Delépine, G. 1940. Les goniatites du Dinantien de la Belgique. - Mémoires du Museé Royal d'Histoire Naturelle de Belgique 91: 1-91.

Ebbighausen, V. \& Bockwinkel, J. 2007. Tournaisian (Early Carboniferous/Mississippian) ammonoids from the Ma'der Basin (Anti-Atlas, Morocco). - Fossil Record 10 (2): 125-163.

Ebbighausen, V., Korn, D. \& Bockwinkel, J. 2010: The ammonoids from the Dalle à Merocanites of Timimoun (Late TournaisianEarly Viséan; Gourara, Algeria). - Fossil Record 13 (1): 153-202. 
Ebbighausen, V., Bockwinkel, J., Korn, D. \& Weyer, D. 2004. Early Tournaisian ammonoids from Timimoun (Gourara, Algeria). Mitteilungen aus dem Museum für Naturkunde Berlin, Geowissenschaftliche Reihe 7: 133-152.

Follot, J. 1951. Note préliminaire sur le Carbonifère de l'Ahnet et du Mouydir (Sahara central). - Bulletin de la Societe Geologique de France 1951 (1): 119-125.

Follot, J. 1952. Ahnet et Mouydir. - 19ième Congrès géologique international, monographies régionales, 1re Série: Algérie 1: 1-80.

Follot, J. 1953. Le Carbonifère inférieur du Sahara central. - Compte Rendue 19ième Congrès géologique international Alger, section 2 (2): 11-28

Foord, A. H. 1901. Monograph of the Carboniferous Cephalopoda of Ireland, Part IV, Containing the families Solenocheilidae (concluded) and Glyphioceratidae. - Palaeontographical Society 55: $127-146$.

Foord, A. H. 1903. Monograph of the Carboniferous Cephalopoda of Ireland, Part V, Containing the families Glyphioceratidae (concluded) and Prolecanitidae, with title-page and index. - Palaeontographical Society 57: 147-234.

Foord, A. H. \& Crick, G. C. 1897. Catalogue of the fossil Cephalopoda in the British Museum (Natural History), Part III, Containing the Bactritidae and part of the suborder Ammonoidea. London: $303 \mathrm{pp}$,

Gordon, M. Jr. 1957. Missisippian Cephalopods of Northern and Eastern Alaska. - Professional Papers of the United States Geological Survey 283: 1-61.

Gordon, M. Jr. 1965. Carboniferous Cephalopods of Arkansas. - Professional Papers of the United States Geological Survey 460: $1-$ 322.

Gutschick, R. C. \& Treckman, J. F. 1957. Lower Mississippian cephalopods from the Rockford Limestone of northern Indiana. - Journal of Paleontology 31: 1148-1153.

Haan, G. de 1825. Monographia Ammoniteorum et Goniatiteorum. Lugduni Batavorum (Hazenberg): 168 pp.

Hahn, G., Hahn, R. \& Korn, D. 2004. Trilobiten aus dem Unter-Karbon Algeriens. - Geologica et Palaeontologica 38: 33-55.

Hall, J. 1860. Notes and observations upon fossils of the Goniatite Limestone in the Marcellus shale of the Hamilton group, in the eastern and central parts of the State of New York, and those of the Goniatite beds of Rockford, Indiana; with some analagous forms from the Hamilton group proper. - Annual Reports of the Regents of the University of the State New York, on the condition of the State Cabinet of Natural History, and the Historical and Antiquarian Collection annexed thereto 13: 59-112, 125.

Hind, W. 1910. On four new Carboniferous nautiloids and a goniatite new to Great Britain. - Proceedings of the Yorkshire Geological Society 17 : 97-109.

Holzapfel, E. 1889. Die Cephalopoden-führenden Kalke des unteren Carbon von Erdbach-Breitscheid bei Herborn. - Palaeontologische Abhandlungen, Neue Folge 5 (1): 1-74

Hyatt, A. 1883-1884. Genera of fossil cephalopods. - Proceedings of the Boston Society of Natural History 22: 253-338 (253-272 publ.1883, 273-338 publ.1884).

Hyatt, A. 1900. Tetrabranchiate Cephalopoda. In Zittel, K. v. (ed.; transl. \& ed. by C. R. Eastman). Text-book of palaeontology, volume 1, 1st edition. McMillan, New York: pp. 502-604.

Klug, C., Döring, S., Korn, D. \& Ebbighausen, V. 2006. The Viséan sedimentary succession at the Gara el Itima (Anti-Atlas, Morocco) and its ammonoid faunas. - Fossil Record 9 (1): 3-60.

Koninck, L. G. de 1844. Description des animaux fossiles qui se trouvent dans le terrain carbonifère de la Belgique, Liège: $650 \mathrm{pp}$.

Koninck, L. G. de 1880. Faune du Calcaire Carbonifère de la Belgique, deuxième partie, Genres Gyroceras, Cyrtoceras, Gomphoceras, Orthoceras, Subclymenia et Goniatites. - Annales du Musée Royal d'Histoire Naturelle de Belgique 5: 1-333.
Konovalova, V. A. 2005. Ammonoid Evolution at the Tournaisian-Visean Boundary. - Paleonotological Journal 39, Supplement 5: S538-S557.

Korn, D. 1988. Die Goniatiten des Kulmplattenkalkes (Cephalopoda, Ammonoidea; Unterkarbon; Rheinisches Schiefergebirge). - Geologie und Paläontologie in Westfalen 11: 1-293.

Korn, D. 1997a. The Palaeozoic ammonoids of the South Portuguese Zone. - Memórias do Instituto Geológico e Mineiro 33: 1-131.

Korn, D. 1997b. Evolution of the Goniatitaceae and Viséan-Namurian biogeography. - Acta Palaeontologica Polonica 42: 177199.

Korn, D. 2010. A key for the description of Palaeozoic ammonoids. Fossil Record 13 (1): 5-12.

Korn, D. \& Ebbighausen, V. 2008. The Early Carboniferous (Mississippian) ammonoids from the Chebket el Hamra (Jerada Basin, Morocco). - Fossil Record 11 (2): 83-156.

Korn, D., Bockwinkel, J. \& Ebbighausen, V. 2007. The Tournaisian and Viséan ammonoid stratigraphy in North Africa. - Neues Jahrbuch für Geologie und Paläontologie 243 (2): 127-148.

Korn, D., Ebbighausen, V. \& Bockwinkel, J. 2010a. The ammonoids from the Grès du Kahla supérieur of Timimoun (Middle-early Late Tournaisian; Gourara, Algeria). - Fossil Record 13 (1): 1334.

Korn, D., Ebbighausen, V. \& Bockwinkel, J. 2010b. Ammonoids from the Dalle des Iridet of the Mouydir and Ahnet (Central Sahara) and the Formation d'Hassi Sguilma of the Saoura Valley (Late Tournaisian-Early Viséan; Algeria). - Fossil Record 13 (1): 203-214.

Korn, D., Klug, C. \& Mapes, R. H. 1999. Viséan and Early Namurian Ammonoids from the Tafilalt (Eastern Anti-Atlas, Morocco). Abhandlungen der Geologischen Bundesanstalt 54: 345-375.

Korn, D., Klug, C. \& Mapes, R. H. 2005. The Lazarus ammonoid family Goniatitidae, the tetrangularly coiled Entogonitidae, and Mississippian biogeography. - Journal of Paleontology 79 (2): 356-365.

Korn, D., Bockwinkel, J., Ebbighausen, V. \& Klug, C. 2003a. Palaeobiogeographic and evolutionary meaning of an early Late Tournaisian ammonoid fauna from the Tafilalt of Morocco. - Acta Palaeontologica Polonica 48 (1): 71-92.

Korn, D., Ebbighausen, V., Bockwinkel, J. \& Klug, C. 2003b. The Amode sutural ontogeny in prolecanitid ammonoids. - Palaeontology 46 (6): 1123-1132.

Korn, D., Belka, Z., Fröhlich, S., Rücklin, M. \& Wendt, J. 2004. The youngest African clymeniids (Ammonoidea, Late Devonian) failed survivors of the Hangenberg Event. - Lethaia 37: 307315 .

Kusina, L. F. 1973. K revizii roda Muensteroceras. - Paleontologicheskiy Zhurnal 1973 (3): 14-25.

Kusina, L. F. 1980. Saurskie amonoidei. - Trudy Paleontologicheskogo Instituta Akademiya Nauk SSSR 181: 1-108.

Kusina, L. F. 2000. Ammonoidei iz pogranichnykh Turneysko-Vizeyskikh otlozhenii. - Paleontologicheskiy Zhurnal 2000 (5): 16-24.

Kusina, L. F. \& Konovalova, V. A. 2004. Novye ammonoidei iz pogranichnykh Turneysko-Vizeyskikh otlozhenii na reke Kozhim (Pripolyanyi Ural). - Paleontologicheskiy Zhurnal 2004 (1): 1018.

Librovitch, L. S. 1927. Nizhnekamennougolnye golovonogie iz rayona ozera Son-kul (Tyan Shan). - Materialy po obschey i prikladnoy geologii, Geologichesky Komitet 74: 1-55.

Librovitch, L. S. 1940. Ammonoidea iz kamennougol'nykh otlozheniy Severnogo Kazakhstana [Carboniferous Ammonoids of North Kazakhstan]. Paleontologiya SSSR 4 (9/1): VI + 392 pp.

Librovitch, L. S. 1957. O nekotorykh novykh gruppakh goniatitov iz kamennougol'nykh otlozheniy SSSR. - Ezhegodnik Vsesoyuznogo Paleontologicheskogo Obshchestva 16: 246-272.

M'Coy, F. 1844. A synopsis of the Carboniferous Fossils of Ireland: VIII +274 pp. 
Miller, A. K. 1931. Two new genera of Late Paleozoic cephalopods from Central Asia. - American Journal of Science, 4th series 522: 417-425.

Miller, A.K. 1935. Burlington goniatites. - American Journal of Science, 4th series 530: 432-437.

Miller, A. K. \& Collinson, C. 1951. Lower Mississippian ammonoids of Missouri. - Journal of Paleontology 25: 454-487.

Miller, A. K. \& Furnish, W. M. 1954. The classification of the Paleozoic ammonoids. - Journal of Paleontology 28: 685-692.

Miller, A. K. \& Furnish, W. M. 1958. Goniatites of the Burlington Limestone of Missouri. - Journal of Paleontology 32 (2): 269274.

Miller, A. K. \& Garner, H. F. 1955. Lower Mississippian cephalopods of Michigan. Part III. Ammonoids and summary. - Contributions of the Museum of Paleontology, University of Michigan 12: 113173.

Miller, A. K. \& Werner, C. 1942. A goniatite from the Mississippian Fern Glen formation of Illinois. - Journal of Paleontology 16: 479-481.

Miller, A. K., Downs, H. R. \& Youngquist, W. 1949. Some Mississippian cephalopods from central and western United States. - Journal of Paleontology 23: 600-612.

Miller, S. A. 1891. Advance sheets of 17th Annual Report. - Annual Reports of the Indiana Department of Geology and Natural Resources 1892: 1-95.

Mojsisovics, E. M.von Mojsvár 1882. Die Cephalopoden der mediterranen Triasprovinz. - Abhandlungen der Kaiserlich-Königlichen Geologischen Reichsanstalt 10: 1-322.

Pareyn, C. 1961. Les Massifs Carbonifères du Sahara Sud-Oranais. Tome II. Paléontologie stratigraphique. - Publications du Centre de Recherches Sahariennes, Série Géologie 1: 1-244.

Parkinson, J. 1822. Introduction to the study of fossil organic remains. I. Sherwood, Neely and. Jones, London: VII + 346 pp.

Petersen, M. S., Korn, D. \& Kullmann, J. 2000. The Early Mississippian (Osagean) ammonoid Dzhaprakoceras (Cephalopoda) from Utah. - Journal of Paleontology 74 (5): 853-857.

Phillips, J. 1841. Figures and descriptions of the Palaeozoic fossils of Cornwall, Devon, and West Somerset. London: XII + $231 \mathrm{pp}$.

Popov, A. V. 1965. Novye vizeyskie ammonoidei Tyan-Shanya. - Paleontologicheskiy Zhurnal 1965 (2): 35-49.

Popov, A. V. 1968. Vizeyskie ammonoidei cevernogo Tyan-Shanya i ikh stratigraficheskoe zhachenie. - Trudy Geologicheskiy Instituta, Kirgizskiy Filial Akademiya Nauk SSSR: 1-116.

Riley, N. J. 1996. Mid-Dinantian ammonoids from the Craven Basin, northwest England. - Special papers in Palaeontology 53: 1-87.

Ruan Yiping 1995. Tournaisian Ammonoids of Northern Xinjiang, China. - Palaeontologia Cathayana 6 (1995): 407-430.

Ruzhencev, V. E., 1950. Verkhnekamennovgolnye ammonity Urala. Trudy Paleontologicheskogo Instituta Akademiya Nauk SSSR 29: $1-220$.

Ruzhencev, V. E. 1965. Osnovnye kompleksy ammonoidei kamennougol'nogo perioda. - Paleontologicheskiy Zhurnal 1965 (2): 3-17.

Schindewolf, O. H. 1922. Über eine Unterkarbonfauna aus Ostthüringen. - Senckenbergiana 4: 8-20.
Schindewolf, O. H. 1923. Beiträge zur Kenntnis des Paläozoikums in Oberfranken, Ostthüringen und dem Sächsischen Vogtlande. I. Stratigraphie und Ammoneenfauna des Oberdevons von Hof a. S. - Neues Jahrbuch für Mineralogie, Geologie und Paläontologie, Beilage-Band 49: 250-357, 393-509.

Schindewolf, O. H. 1926. Beiträge zur Kenntnis der Cephalopodenfauna des oberfränkisch-ostthüringischen Unterkarbons. - Senckenbergiana 8: 63-96.

Schindewolf, O. H. 1939. Bemerkungen zur Stratigraphie des oberfränkisch-ostthüringischen Unterkarbons. - Jahrbuch der PreuBischen Geologischen Landesanstalt 59 (for 1938): 456-475.

Schindewolf, O. H. 1951. Über ein neues Vorkommen unterkarbonischer Pericyclus-Schichten im Oberharz. - Neues Jahrbuch für Geologie und Paläontologie, Abhandlungen 93 (1): 23-116.

Shimansky, V. N. \& Kusina, L. F. 1977. Rannekamennougolnye golovonogie pripolyatnogo Urala. - Byulleten' Moskovskogo Obshchestva Ispytateley Prirody, Otdel Geologicheskiy 52 (6): 7990.

Swallow, G. C. 1860. Descriptions of new fossils from the Carboniferous and Devonian rocks of Missouri. - Transactions of the St. Louis Academy of Science 1: 635-660.

Termier, G. \& Termier, H. 1950. Paléontologie Marocaine. II. Invertébrés de l'ére Primaire. Fascicule III. Mollusques. - Notes et mémoires, Service Géologique, Protectorat de la République Française au Maroc, Direction de la Production Industrielle et des Mines, Division des Mines et de la Géologie 78: 1-246.

Turner, J. S. 1948. Mid-Dinantian reef limestones of Dublin and Cork. - Transactions of the Leeds Geological Association 6 (2): 44-56.

Wedekind, R. 1914. Beiträge zur Kenntnis der Oberkarbonischen Goniatiten. - Mitteilungen aus dem Museum der Stadt Essen für Natur- und Völkerkunde 1: 1-22.

Wendt, J., Kaufmann, B., Belka, Z. \& Korn, D. 2009. Carboniferous stratigraphy and depositional environments in the Ahnet Mouydir area (Algerian Sahara). - Facies 55 (3): 443-472.

Winchell, A., 1862: Notice of the rocks lying between the Carboniferous limestone of the Lower Peninsula of Michigan and the limestones of the Hamilton group; with descriptions of some cephalopods supposed to be new to science. - American Journal of Science and Arts 33: 352-366.

Work, D. M. \& Mason, C. E. 2003. Mississippian (middle Osagean) ammonoids from the Nada Member of the Borden Formation, Kentucky. - Journal of Paleontology 77 (3): 593-596.

Work, D. M. \& Mason, C. E. 2004. Mississippian (late Osagean) ammonoids from the New Providence Shale Member of the Borden Formation, north-central Kentucky. - Journal of Paleontology 78 (6): MB.C.19052.2-1137.

Work, D. M. \& Mason, C. E. 2005. Mississippian (early Osagean) Cave Run Lake ammonoid fauna, Borden Formation, northeastern Kentucky. - Journal of Paleontology 79 (4): 719-725.

Work, D. M., Nassichuk, W. W. \& Richards, B .C. 2000. Lower Viséan ammonoids from the Lower Mount Head Formation, EastCentral British Columbia. - Bulletin of the Geological Survey of Canada 541: 1-71. 